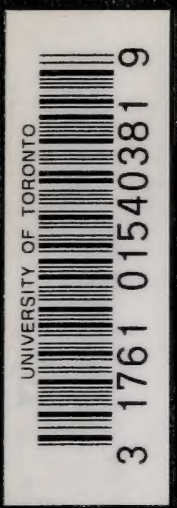



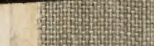

5.

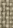

(1)

(1)

3.t.5.
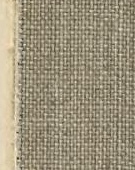

is 

Digitized by the Internet Archive in 2007 with funding from Microsoft Corporation 


\section{ESSAYS ON WHEAT}




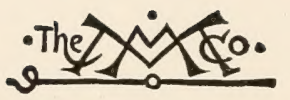

THE MACMILLAN COMPANY

NEW YORK - BOSTON - CHICAGO - DALLAS

ATLANTA - SAN FRANCISCO

MACMILLAN \& CO., Limited

LONDON - BOMBAY - CALCUTTA

MELBOURNE

THE MACMILLAN CO. OF CANADA, LTD. TORONTO 



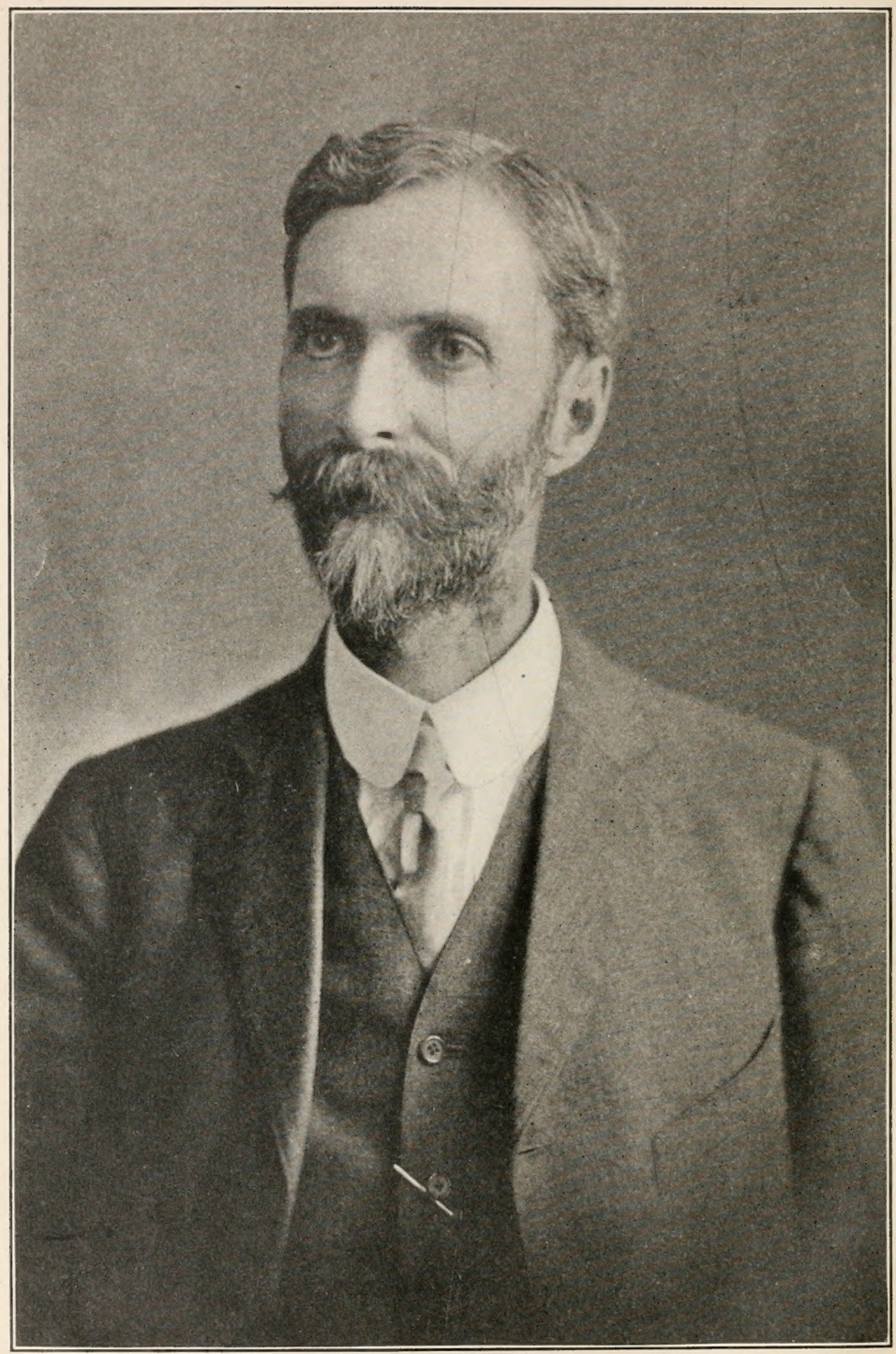

DR. CHARLES SAUNDERS,

The discoverer and introducer of Marquis Wheat. 


\section{ESSAYS ON WHEAT}

\section{INCLUDING}

THE DISCOVERY AND INTRODUCTION OF MARQUIS WHEAT, THE EARLY HISTORY OF WHEAT-GROWING IN MANITOBA, WHEAT IN WESTERN CANADA, THE ORIGIN OF RED BOBS AND KITCHENER, AND THE WILD WHEAT OF PALESTINE

BY

A. H. REGINALD BULLER B.Sc. (London); D.Sc. (Birmingham); Рh.D. (Leipzig); F.R.S.C. Professor of Botany at the University of Manitoba

WITH FIFTY ILLUSTRATIONS IN THE TEXT

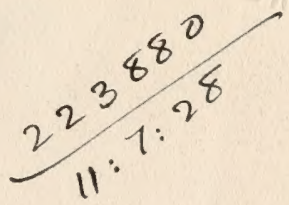

Jem 㷅地 THE MACMILLAN COMPANY 1919 
Copyright, 1919
By the MACMILLAN COMPANY
ap and electrotypes. Published December,

$S B$

191

W51395

cop. 2 
History ... celebrates the battlefields whereon we meet our death, but scorns to speak of the plowed fie?d.s whereby we thrive; it knows the names of the king's bastards, but cannot tell us the origin of wheat. That is the way of human folly.

J. Henri Fabre. 



\section{PREFACE}

Marquis Wheat is one of the most valuable food plants in the world. In the year 1917 upwards of 250,000,000 bushels of it were raised in North America, and in 1918 upwards of $300,000,000$ bushels; and, owing to its high yield per acre, it was an important factor in assisting the Allies to orercome the food crisis in the darkest period of the war. The whole of the Marquis Wheat at present in existence originated from a single grain of wheat planted in an experimental plot at Ottawa by Dr. Charles E. Saunders so recently as the spring of 1903 .

I have written this book, in the first place, to do justice to Dr. Charles E. Saunder's as the discoverer and introducer of Marquis, and, in the second place, to put on record facts which have an important bearing upon the agricultural progress of both Canada and the United States. I undertook the task of penning the history of Marquis with all the more pleasure on account of the fact that I have lived for nearly fifteen years at Winnipeg, in the center of the great spring-wheat region of North America, and for the reason that, as a Canadian citizen, I have shared in the general prosperity that has come to the Dominion through the development of her wheat-lands.

The heart of what I wish to say is contained in the Third Chapter on The Discovery and Introduction of Marquis Wheat; but, for the purpose of making the book more comprehensive and of supplying information for which I feel there is a considerable demand, I have written two preliminary chapters, called respectively: The Early vii 
History of Wheat-groung in Manitoba, and Theat in Western Canada, and two concluding chapters upon The Origin of Red Bobs and Kitchener and The Wild Wheat of Palestine.

In order to collect the data embodied in the following pages I have engaged in an extensive correspondence, have made many inquiries at Winnipeg, and hare visited Ottawa, Brandon, Indian Head, Saskatoon, and Rosthern in Canada, and Fargo, Minneapolis, and St. Paul in the United States. I have also investigated personally the sampling and grading of wheat at Winnipeg, of which an account is given in the second Chapter. To the numerous cerealists, grain growers, grain merchants, millers, statisticians and others who have assisted me with information and criticism, I here wish to express my hearty thanks.

A. H. Reginald Buller, Winnipeg, April 10, 1919. 


\section{CONTENTS}

Preface - . • . . . . . . . . . . . vii

\section{CHAPTER I}

The Early History of Wheat-Growing in Manitoba SECTION

I The First Wheat Crops in Western Canada . . $\quad 1$

II Troubles with the Nortl-West Company . . 4

III Visit of Lord Selkirk . . . . . . . 8

IV The First Farms . . . . . . . . . . 9

$\nabla$ The Plague of Grasshoppers . . . . . . 10

VI New Seed-Wheat from the United States . . 12

VII The Hour-Glass . . . . . . . . . 14

VIII The Census of 1822 . . . . . . . . . 16

IX Milling Operations . . . . . . . . 16

$\mathrm{X}$ The Hice . . . . . . . . . . . 18

XI The Great Flood . . . . . . . . 18

XII Prosperity in 1829 . . . . . . . . 20

XIII The Red River Flour . . . . . . . 21

XIV Windmills . . . . . . . . . . 24

XV The Experimental Farms . . . . . . . 24

XVI The Bloody Flux . . . . . . . . . 26

XVII The Census of 1849 . . . . . . . . . 27

XVIII Another Plague of Grasshoppers . • . . . 28

XIX State of the Settlement in 1870 . . . . 29

XX Effect of the Revolution in the Milling Industry 30

XXI The St. Paul Railway . . . . . . . 32

XXII The Canadian Pacific Railway . . . . 33

\section{CHAPTER II}

\section{Wheat in Western Canada}

I Some Crop Statistics . . . . . . . . 35

II Wheat Growing . . . . . . . . . 41 
SECTION

III The Great Wheat Funnel

$\cdot \cdot \cdot \cdot 49$

IV The Hudson Bay Railway . . . . . . . 51

V The Shipment of Bulk Wheat through the Panama Canal . . . . . . . . 52

VI Elevators . . . . . . . . . . . 53

VII The Loading Platform . . . . . . . 54

VIII The Old Flat Warehouse . . . . . . 55

IX The Country Elevator . . . . . . . 56

X Box-Cars . . . . . . . . . . . 57

XI Terminal Elevators . . . . . . . 60

XII Lake Steamers . . . . . . . . . . 65

XIII The Lake Shippers' Clearance Association . . 66

XIV The Canada Grain Act . . . . . . . . 68

XV The Sample Market . . . . . . . . . 69

XVI The Grades of Grain . . . . . . . . 70

XVII The Grading of Grain . . . . . . . . 75

XVIII Inspection at Terminal Elevators . . . . . 93

XIX Reinspection . . . . . . . . . . . 96

XX Weighing Wheat . . . . . . . 98

XXI Warehouse Receipts, Registration, and Stocktaking . . . . . . . . . . 100

XXII The Dominion Grain Research Laboratory . . 102

XXIII The Winnipeg Grain Exchange . . . . . 105

XXIV The Geographical Position of the Grain Exchange . . . . . . . . 108

XXV The Grain Exchange Clearing House • . . 109

XXVI The Wheat Pit . . . . . . 116

XXVII The Effect of the War on the Grain Trade . . 118

XXVIII Financing the Crop Movement . . . . 130

XXIX The Flour Mills of Western Canada . . . . 134

XXX Recent Improvements in the Conditions of Farm Life

XXXI The Agrarian Movement

\section{CHAPTER III}

The Discovery and Introduction of Marquis Wheat

I Introduction . . . . . . . . . . . 144

II Dr. William Saunders and His Assistants . . 144

III The Selection of Marquis by Dr. Charles E.

Saunders 
- IV The New Wheat ir Named . . . . . . 154

V The Qualities of Marquis are Investigated . . 154

VI The Introduction of Marquis into Western

Canada . . . . . . . . . . 157

VII The Introduction of Marquis into the United

States of America . . . . . . . 158

VIII General Description of Marquis . . . . . 170

IX Prizes Awarded to Marquis . . . . . . 172

X Long-Period Tests for Earliness and Yield . . 174

XI Earliness and the Gain of Working-time . . 175

XIJ Earliness and Storms . . . . . . . . 176

XIII Earliness and Rust . . . . .... 176

XIV Earliness and Frost . . . . . . . . 180

XV Marquis, Ruby, and Prelude. . . . . . 183

XVI The Advance Toward the North of the Belts of

Wheat and Corn . . . . . . . 187

XVII The Yield of Marquis in Western Canada . 190

XVIII The Yield of Marquis in the United States . . 192

XIX The Favorable Grading of Marquis . . . . 196

XX Resistance to Shelling . . . . . . . 197

XXI Milling and Baking Qualities . . . . . . 198

XXII The Origin of Hard Red Caloutta . . . . 204

XXIII The Origin of Red Fife . . . . . . . 206

XXIV Marquis as the Off-spring of Red Fife and Hard

Red Calcutta . . . . . . . . . . 218

XXV The Future of Marquis . . . . . . . 223

XXVI Saunders and Burbank . . . . . . . .228

XXVII Burbank's Quality Wheat as a Possible Competitor of Marquis . . . . . . . 233

XXVIII Biographical Sketah of the Discoverer of Marquis . . . . . . . . . 237

XXIX Governing Bodies and Scientific Research . . 238

XXX Other Work of Dr. Saunders . . . . . . 239

XXXI The Crop Value of Marquis in Canada and the United States . . . . . . . 243

XXXII The Increased Wealth Brought by Marquis to the United States . . . . . . . . 246

XXXIII The Increased Wealth Brought by Marquis to Canada . . . . . . . . . . 252

XXIV Summary . . . . . . . . . . 257 


\section{CHAPTER IV}

The Origin of Red Bobs and Kitchener

SECTION PAGE

I Introduction . . . . . . . . . . . 259

II Origin of Bobs . . . . . . . . . . 259

III Importance of the Color of Wheat Kernels . . 260

IV The Discovery of Red Bobs by Mr. Seager

Wheeler . . . . . . . . . . 262

$\nabla$ Red Bobs the Product of a Natural Cross . . 264

VI The Selection, Multiplication, and Distribution of Red Bobs . . . . . . . . . . 268

VII Red Bobs at the University of Saskatchewan. 270 VIII Description of Red Bobs . . . . . . . 272

IX A Visit to Mr. Wheeler's Farm . . . . . 272

X A Biographical Note . . . . . . . 274

XI Kitchener . . . . . . . . . . . . 275

\section{CHAPTER V}

\section{The Wild Wheat of Palestine}

I The Importance and Antiquity of Agriculture . 278

II The Antiquity and Origin of Wheat . . . . 279

III The Prototypes of Cereals . . . . . . . 285

IV Körnicke's Discovery in a Herbarium . . . 286

V Rediscovery of the Wild Wheat by Aaronsohn . 286

VI The Botanical Classification of Wheats . . . 292

VII The Brittle Rachis of the Primitive Cereals . 293

VIII Cultivated Wheats with a Brittle Rachis . . 295

IX Einkorn and Its Prototype Distinct from Other

Wheats . . . . . . . . 296

X Emmer the Only Possible Prototyne of True Wheat . . . . . . . . 298

XI Cross-fertilization . . . . . . . . 299

XII Conclusion . . . . . . . . . 306

Index . . . . . . . . . . 307 


\section{LIST OF ILLUSTRATIONS}

Frontispiece. Dr. Charles Saunders.

1. Map showing Lord Selkirk's grant of land, the route of the Selkirk Settlers, and the boundaries of Manitoba

2. Hebrides women grinding with the quern or hand-mill 17

3. Combined acreage of spring-sown and autumn-sown wheat in western Canada . . . . . . . 37

4. Breaking the virgin prairie of Manitoba with a four-horse plow (facing page) . . . . . . . 44

5. Cutting the wheat crop with a four-horse binder (facing page) . . . . . . . . . . . 45

6. Wheat in the stook in western Canada (facing page) 46

7. Threshing wheat on the prairie (facing page) . . . 47

8. Eastbound movement of western Canadian wheat in the calendar year 1913 . . . . . . . . 50

9. Country elevators at a railway station, rear view (facing page) . . . . . . . . . 56

10. View of Canadian Pacific Railway yards in the busy season at Winnipeg (facing page) . . . . . .

11. The Dominion Government Terminal Elevator at Port Arthur (facing page) . . . . . . . . . . 62

12. Unloading a car of grain (facing page) . . . . 63

13. Design for the Dominion Government elevators at Saskatoon, Moosejaw, and Calgary (facing page) .

14. A gang ready to start the work of sampling (facing page) · · • • • • •

15. Probing the grain, showing the sampler with his probe or stabber (facing page) . . . . . . . .

16. Emptying the grain upon the cloth through the handle of the stabber as practiced until recently (facing page) 
17. The inspectors at work in Winnipeg (facing page) .

18. Weighing the grain to determine its weight per bushel and setting the dockage (facing page) . . . . 88

19. Taking a sample from a belt in a tunnel of the Dominion Government Terminal Elevator (facing page) 94

20. Taking a sample on a steamer loading at the Dominion Government Terminal Elevator (facing page) . . 95

21. The late Dr. William Saunders (facing page) . . . 146

22. A head of Marquis (facing page) . . . . . . 152

23. Small plots of cereals with peas in the foreground at the Central Experimental Farm (facing page) . . . 153

24. Test plots of cereals at the Central Experimental Farm (facing page)

25. Marquis Wheat in the Banner Season of 1915 (facing page) . . . . . . . . . . 157

26. Cutting Marquis Wheat at the Experimental Farm, Brandon, Manitoba (facing page) . . . . . 160

27. Marquis wheat in stook at Brandon (facing page) . . 161

28. Reference map for the United States . . . . . 163

29. Spike of Marquis Wheat compared with spikes of Minnesota standard varieties (facing page)

30. Kemels of Marquis Wheat compared with kernels of Minnesota standard varieties (facing page). . . 166

31. Cross-sections of Wheat Kernels. Marquis compared with Minnesota standard varieties (facing page). .

32. Prelude on the left and Marquis on the right, sown at the same time, showing relative earliness of Prelude in heading out (facing page) .

33. Normal loares from three varieties of wheat and one of rye, showing characteristic differences in loaf volume (facing page)

34. Cereal and forage crops building at the Central Experimental Farm, Ottawa (facing page)

35. Kneading table and cupboard where the dough is put to rise in the testing of new wheats for bread-making at the Central Experimental Farm, Ottawa (facing page) .

36. Dr. Charles Saunders in a field of Marquis wheat (facing page) 
37. Small plots of cereals, new cross-bred varieties, and new selections at the Central Experimental Farm, Ottawa (facing page) . . . . . . . . . 238

38. Selected Manchurian barley at the Experimental Farm,

Indian Head, Saskatchewan (facing page) • . . 239

39. Dr. Charles Saunders crossing wheats at the Central

Experimental Farm, Ottawa (facing page) . . . 240

40. Liberty oats (hulless), August, 1918 (facing page) • . 241

41. Typical heads of Red Bobs wheat (facing page) . . 262

42. Mr. Seager Wheeler in a plot of wheat at Rosthern,

Saskatchewan (facing page) . . . . . . . 272

43. Demeter enthroned . . . . . . . . . . 281

44. View of Mejdel esh Schems, on the slopes of Mount

Hermon, where Wild Wheat was found (facing page) 288

45. Heads of an ordinary form of the Wild Wheat of Palestine as grown at Bard, California (facing page) . 289

46. Wheat Kernels. A, Wild Wheat showing usual size;

$\mathrm{B}$, large-seeded variation of Wild Wheat; C, Sonora wheat commonly grown in the same locality at Bard, California (facing page) . . . . . . . . 290

47. Classes of Wheat; Wheat, Durum, Club (facing nage) 291

48. Classes of Wheat; Poulard, Polish, Spelt, Einkorn, Wild Wheat of Palestine (facing page) . . . . 294

49. Classes of Wheat; Bobs, White Fife, Taylor's Wonder, and Emmer (facing page) . . . . . . . 295

50. Head of a large-seeded variation of the Wild Wheat

(Triticum hermonis) with the spikelets falling apart (facing page) 



\section{ESSAYS ON WHEAT}

\section{CHAPTER I}

The Early Histori of Wineat-Growing in Manitoba

\section{The First Wheat Crops in Western Canada}

THE earliest attempts at the cultivation of wheat in western Canada are associated with the vicissitudes of the Selkirk settlers and date from the year 1812. This little band of pioneers was sent out from Scotland by Lord Selkirk, via York Factory, to colonize 116,000 square miles of territory granted him by the Hudson's Bay Company. An advanced party of twenty-two men under the direction of Miles Macdonell arrived at the junction of the Red and Assiniboine rivers on August 30, 1812; and there they founded the Red River Settlement. ${ }^{1}$ To make provision for the future, they at once began to turn up the sod; and part of the breaking was sown with winter wheat brought from their native land. Some spring wheat having the same origin was also sown early in 1813. In the fall of that year, the settlers, whose numbers by this time had increased to nearly one hundred, were dismayed to find that the wheat harvest was a total failure. ${ }^{2}$ There was

1 Cf. Chester Martin, Lord Selkirk's Work in Canada, Oxford, 1916, p. 43 .

2 Governor Miles Macdonell in a letter to Lord Selkirk dated July 17, 1813, states that: "Winter wheat being late-sown has totally failed as also the summer wheat, pease, and English barley." Selkirk Papers, p. 788.

For this and the other references to the Selkirk Papers which are unpublished and contained within the Archives Building at Ot- 
nothing to be done but to try again; but as oin Fortune refused to smile upon the newcomers, and the clip of 1814 was as bad as its predecessor. ${ }^{3}$ But Scotch per ${ }^{\text {sistency }}$ was to win in the end, for the third attempt at wheat-rowing, made in 1815, was eventually brought to a successtill conclusion.

The failure of the first two crops of wheat was due partly to the fact that the earliest settlers to arrive at the Red River were crofters who knew more of fishing than of farming, and partly to the absence of adequate farm implements. There was not a plow in the whole colony, the one harrow was incomplete and could not be used, and all the labor of breaking up and working over the tough prairie sod had to be done with the hoe. ${ }^{4}$ The Indians looked on with surprise and amazement at the man with the hoe seeking to gain a sustenance from the soil, and to show his contempt for such work nicknamed the colonists "Jardiniers." s

The fertility of the soil along the banks of the Red River was doubtless just as great when the colony was founded as it is to-day. Although the cereals of 1813 and 1814 failed, other crops, such as potatoes and turnips, did well from the first. Miles Macdonell, writing in the winter of 1813-1814 and telling of the harvest in the previous year, says ${ }^{6}$ : "I had five or six hundred kegs of potatoes and tawa, I am indebted to my colleague, Professor Chester Martin, who kindly gave me access to the notes which he made when studying the original documents.

3 Ibid. July 25, 1314. Macdonell says: "Wheat, pease, beans, Indian corn, rye, and hemp entirely failed." Selkirk Papers, p. 1183.

4 G. Bryce, The Romantic Settlement of Lord Selkirk's Colonists, Winnipeg, 1909, pp. 87-88.

5 Ibid., pp. 20-21.

B Miles Macdonell in a letter to Auld, February 4, 1814, Selkirk Papers. 


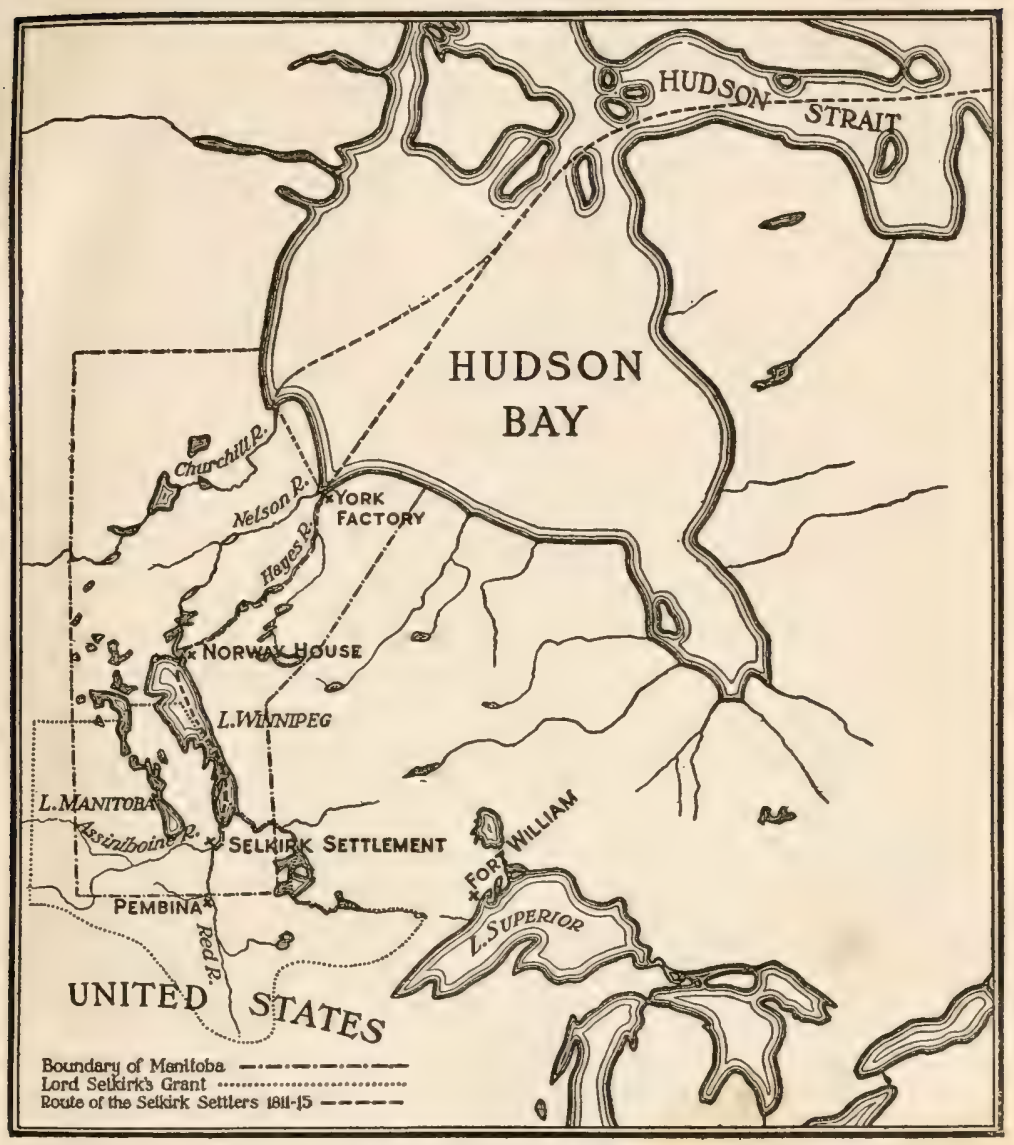

Fig. 1. Map showing Lord Selkirk's grant of land, the route of the Selkirk settlers, 1811-15, and the present boundaries of the Province of Manitoba. 
some of the people who cultirated for themselves had returns of at least fifty for potatoes." The turnips were "of extraordinary size"; but of the wheat, barler, and rye there was nothing good to report, for " the grain was choked up with weeds." " The choking of the grain with weeds was probably due either to impure seed or to inexperienced labor. It is interesting to note that the weed nuisance which the weed inspectors and farmers of Manitoba are to-day so vigorously combating, should hare made its appearance over a century ago as soon as the virgin soil was turned into farm land.

One of the settlers appears to have userl his hoe to greatr $\mathrm{r}$ advantage than his fellows, for the story goes that in 1813 from four quarts of seed-wheat obtained from Fort Alexander, a trading post on the Winnipeg River, he reaped twelve and a half bushels or an increase of one hundredfold. ${ }^{8}$ It is safe to say that an increase of one hundredfold in wheat is unknown in the experience of the Manitoban farmer at the present day, and it may be that the tradition of the high yield of twelve and a half bushels from oneeighth of a bushel contains an imaginary element.

The first harvests stood in danger from the air, for each autumn flocks of birls, including the now extinct Passenger Pigeon, settled in the fields and considerably diminished even such small crops as had been produced. ${ }^{9}$

\section{Troubles with the North-West Company}

The Red River settlers, in the first few year's of their

\section{Ibid.}

8 A. Ross, The Red River Settlement, London, 1856, pp. 23-24. This incident is said by Ross, who came to the colony in 1825, to have happened in 1813 but this may be an error in chronology, for Miles Macdonell (vide a previous footnote) deinitely reported in 1813 that both the winter and the spring wheat totally failed.

9 Ibid., p. 24. Dr. C. N. Bell, who came to Winniper nearly fifty 
history, had not merely to struggle with Nature to provide themselves with their daily bread but also with their fellow men. The Xorth-West Company which, as fur traders, was the great rival of the Hudson's Bay Company, resented the establishment of a civilized community in the heart of the Indian country : firstly, because it was planted directly across their main line of communication between the North-West and Montreal and, secondly, because it was situated on the very plains from which they drew their supplies of pemmican for their royages from Fort William to the posts of the fur trappers. The Company feared that the Settlement might eventually destroy the fur trade, and they therefore determined to destroy the Settlement. ${ }^{10}$

In the spring of 1815 , the Selkirk settlers sowed their wheat and barley; but many were the hardships to be borne before the crops could be reaped. In June, the NorthWesters with their half-breed adherents overawed the colonists by a show of foree. Ther trampled upon the crops, stole the horses, and burnt Fort Douglas, the colony mill, the stables and barns to the ground; and Miles Macdonell, the Gorernor of the colony, surrendered himself as a prisoner. Most of the settlers left in North-West canoes for T'pper Canada, and thirteen families made their way up Lake Winnipeg to Jack River and settled at a place now known as Norway House. John McLeod and three others, however, succeeded in weathering the storm and remained at the Forks. They stored what property they could in a single log-house and stoutly defended themselves with a three-pounder cannon fed with lengths of chain obtained from the adjoining blacksmith's shop. Their halfrears ago, has informed me that he used to shoot Passenger Pigeons on the banks of the Red River where the Winnipeg Grain Exchange is now situated.

10 ' $f$. Donald Gunn, Report from the Select Committee on the Hudson's Bay Company, 1857, p. 382. 
breed assailants, who were on horseback, could not face this piece of artillery and soon desisted from their attacks. In the end, McLeod and his little garrison were left in peace to care for the crops and prepare for the return of their friends. ${ }^{11}$

Colin Robertson, in charge of an expedition sent out by Lord Selkirk from Montreal, arrived at the Red River a few weeks after the expulsion of the colonists. On learning what had happened, he immediately pushed up Lake Winnipeg to the Jack River, persuaded the settlers to return, and brought them back in triumph. They were delighted to find that, during their absence, the crops had made good progress; and within a few weeks the first successful harvest was duly gathered in.

The new Governor, Robert Semple, who had been sent out from Scotland by the Hudson Bay route, arrived at the Red River Settlement on November 3, 1815. On finding that there were one hundred and twenty persons committed to his care, he at once began to feel anxious about the food-supply for the winter. Straightway he went to the granary where a rapid inspection revealed that the stores of grain consisted of from 12 to 14 stacks of wheat and barley. Would this satisfy the needs of the settlers and keep famine from their doors until the next harvest? A resort to mathematics could alone settle the question. Taking each stack as representing 50 bushels each, he calculated that he had 400 bushels of wheat plus 200 bushels of barley. From these 600 bushels he deducted 40 for spring seed and so had 560 left. Counting 50 pounds to the bushel, he calculated that the grain which could be used as food amounted to 28,000 pounds. He then reckoned that 120 persons at 2 pounds per day would

11 Chester Martin, loc. cit., pp. 85-89; also G. Bryce, loc. cit., p. 105. 
consume 240 pounds per day, and that this was equal to 7,200 pounds per month or 28,800 pounds for 4 months an amount of grain but little more than the 28,000 pounds he actually had at his disposal. And so the Settlement would be free from the trials of hunger throughout the winter of 1815-16. "How was my heart relieved," writes Semple to Lord Selkirk, "when I arrived at the end of this simple calculation which $I$ tried again and again for fear of a mistake." 12

In the spring of 1816 the settlers sowed the forty bushels of seed wheat and seed barley which had been saved from the crop of the previous year, but alas for their hopes of harvest! Within a few short weeks, when every field was putting on its summer garb of green, the colony was to be broken up once more, and a goodly number of the settlers were to find their graves. The quarrel between the rival Companies came to such a pass that, on June 19, a bloody combat took place between their rival forces. A boy on the watch-tower of Fort Douglas sighted a large gathering of hostile half-breeds; and Governor Semple and about thirty of his men went out to meet them. At a spot known as Seven Oaks, a few miles north of Winnipeg near the Red River, the two parties came together. The half-breeds were painted and disguised. Hot words were exchanged, a shot was fired, and in the fight which followed Governor Semple and twenty of his men were left dead upon the field. ${ }^{13}$ The rest of the settlers in bereavement and despair made their way up Lake Winnipeg, and, after a long and wearisome journey, again took up their abode at Jack River. ${ }^{14}$ The North-IVesters occupied Fort Douglas until

12 Letter of Governor Semple to Lord Selkirk, Dec. 20, 1815, Selkirk Papers, p. 2721.

13 Cf. Chester Martin, loc. cit., pp. 110-112.

14. John Macoun, Manitoba and the Great North-West, Guelph, 1882, p. 437. 
the end of the year; and, after this second expulsion, no colonist was permitted to remain to gather in the crops.

Early in 1817, in the depth of winter, a force sent from Fort William by Lord Selkirk wrested Fort Douglas from the North-West Company. A surprise attack was marl.. in the dead of night: the walls were sealed, and the sixtecn? men within were all made prisoners. When daylight came, the flag of the Hudson's Bay Company was again hoisted on the staff. ${ }^{15}$ With the arriral of spring, an express canoe was dispatched to Jack River with the news that Fort Douglas had been taken. The settlers were persuaded to return, and, in the hope that peace might finally be established, resumed their agricultural pursuits. However, the facilities for tilling the soil were extremely limited and it was still necessary to use the hoe in place of the plow. ${ }^{16}$ Wheat was sown although late in the year and, owing to its scarcity, in small quantity. It grew well but, in the autumn, the crop was almost ruined by a violent hurricane. So short of cereals were the colonists during the winter of $1817-18$ that they had to rely upon the buffalo as a chief source of food. ${ }^{17}$

\section{Visit of Lord Selkirk}

Lord Selkirk, who was an experienced agriculturist, arrived at the Settlement in the summer of $181 \%$, and for four months exercised a wise and generous supervision over its affairs. ${ }^{18}$ His heart was in this work, for he had great visions of the future. His belief in the possibilities of the western prairie-land he once expressed in a remarkable prophecy: "It is a very moderate calculation to say that

15 Chester Martin, loc. cit., p. 127.

16 John Macoun, loc. cit., p. 437.

17 Chester Martin, loc. cit., p. 140.

18 Ibid., p. 133. 
if these regions were occupied by an industrious population, they might aftord ample means of subsistence for thirty millions of British subjects." 19 So anxious was Lord Selkirk to encourage agriculture that before his arrival, in 1815, he had authorized Semple and Robertson to offer on his behalf a prize of $£ 50$ to the farmer who should raise the largest quantity of grain in proportion to the number of hands employed. ${ }^{20}$

Lord Selkirk left the Settlement on September 9, 1817, for Mrontreal in order to answer charges brought against him at the instigation of the North-West Company. The litigation in which he became involved affected his health, which he attempted to recover by a visit to Pau in France. There his end eame on April 8, 1820; and the man whose indomitable spirit caused the sowing of the first fields of wheat in western Canada and who, with the insight of a seer, foresaw the present and the future agricultural prosperity of the far-spreading prairie-land, now lies buried in a French graveyard. The North-West Company and the IIudson's Bay Company settled their differences by amalgamation in 1821, a year after Lord Selkirk's death. ${ }^{21}$

\section{The First Farms}

The Red River Settlement, in the first few years of its existence, concentrated its farming operations in what is to-day known as the municipality of Kildonan. It was arranged that each settler should purchase one hundred acres of land at five shillings an acre, but Lord Selkirk relinquished his claim to payment, when he visited the

19 Ibicl., p. 185.

20. Celkirk to Semple and Robertson, letter written December 18, 1815, Selkirk Papers.

21 Chester Martin, Lord Selkirk's Work in Canada, Oxford, 1916. p. 165 . 
colony in 1817, in order to help the settlers who had suffered so much in the two previous years. For the purpose of giving each farmer access to the main highway the Red River - and to secure the advantage of compactness for the colony as a whole, the farms were all made long and narrow with one end fronting on the water, and were placed side by side in a parallel series. Lord Selkirk thus describes twenty-four ten-chain lots which he granted to the settlers in free soccage: "Each lot has a front of ten chains, or 220 yards, a little more or less, along the said main line, except Lot No. 12 which has only five chains. The division lines between the lots are at right angles to the main line, and are marked off towards the river by lines of stakes. Each lot is to extend to the distance of 90 chains or 1,980 yards back from the river, so as to contain 90 English statute acres, besides which each lot is to have a separate piece of wood-land, containing 10 statute acres, to be laid off on the east side of the river, at any place which the Earl of Selkirk or his agent shall consider as most suitable for the purpose." 22

\section{The Plague of Grasshoppers}

During the next few years succeeding Lord Selkirk's departure, the Settlement was plagued with grasshoppers. Alexander Macdonell, in a letter to Lord Selkirk, stated that millions of these pests had appeared on August 2, 1818 , and that in places they were two or three inches deep. ${ }^{23}$ Ross thus vividly describes the destruction wrought by these insects. "Every step was now a progressive one: agricultural labor advanced, the crop looked healthy and vigorous, and promised a rich harvest. In short, hope once more revived, and everything began to

22 A. Ross, The Red River Settlement, London, 1856, p. 43.

23 Governor Alexander Macdonell to Lord Selkirk, Selkirk Papers. 
put on a thriving and prosperous appearance: when lo! in the midst of all these pleasing anticipations, just as the corn was in the ear, and the barley almost ripe, a clond of grasshoppers ${ }^{24}$ from the west darkened the air, and fell like a heavy shower of snow upon the devoted colony. This stern visitation happened in the last week of July, and late one afternoon. Next morning when the people arose it was not to gladness but to sorrow; all their hopes were in a moment blighted! Crops, gardens, and every green herb in the settlement had perished, with the exception of a few ears of barley, half ripe, gleaned in the women's aprons. This sudden and mexpected disaster was more than they could bear. The unfortunate emigrants, looking up towards heaven, wept." 25 Once more the settlers found it necessary to leave their homes and go to Pembina where starvation might be staved off with buffalo meat.

Early in the spring of 1819, the Scotch settlers returned from Pembina to Kildonan and sowed the grain of such

24 The insect which was responsible for the plague of 1818 , and for subsequent plagues in 1864,1857 , etc., was known to the Red River settlers as a grasshopper; but, as I am informed by my colleague Dr. Charles H. O'Donoghue of the Department of Zoölogy, it would be more correctly designated a locust. A certain amount of confusion exists as to the correct application of the terms grasshopper and locust. It is preferable to apply the term locust to those forms which migrate in long-distance flights and which usually are of large size. On the other hand, the Field Grasshoppers, so common on our sidewalks, are usually smaller animals and progress only by characteristic, short flights. It is ohvious, therefore, that the insect seen by the settlers, although of medium size, was a migratory locust. The species is known scientifically, according to information sent me by Dr. Gordon Hewitt, the Dominion Entomologist, as the Rocky Mountain Locust, Melanoplus spretus. During recent decades, this pest has not again appeared. Dr. Hewitt thinks that this may be due to the northward extension of agriculture and the possible decrease in the insect's breeding places.

25 A. Ross, loc. cit., p. 48. 
cereals as had been rescued from the grasshoppers the previous year. But the attempt to raise wheat and barley was again defeated "not by a new flight of the pestilence of last year, but, still worse, by the countless swarms produced in the ground itself where their larvæ had been deposited. As early as the latter end of June, the fields were overrum by this sickening and destructive plague; nay, ther were produced in masses, two, three, and in some places, near water, four inches deep. The water was poisoned with them. Along the river they were to be found in heaps, like seaweed, and might be shoveled with a spade. It is impossible to describe, adequately, the desolation thus caused. Every vegetable substance was either eaten up or stripped to the bare stalk; the leaves of the bushes, and the bark of the trees, shared the same fate; and the grain vanished as fast as it appeared above ground, leaving no hope either of 'seed to the sower or bread to the eater.' Even fires, if kindled out of doors, were immediately extinguished by them, and the decomposition of their bodies when dead, was still more offensive than their presence when alive." 26

Thus it came to pass that by the vear 1820 there was no more seed-wheat left in the colony. The history of the first variety or varieties of wheat grown in western Canada, which, as we have seen, were of British origin, thus came to an untimely close.

\section{New Seed-Wheat from the United States}

In order to secure a supply of seed-wheat to sow the land in the spring of 1820 , the Selkirk settlers found it necessary to dispatch a party of men to Prairie du Chien, a town on the banks of the Mississippi in the State of 26 A. Ross, loc. cit., pp. 49, 50. 
Wisconsin. After journeying for several hundreds of miles on snow-shoes, the men arrived at their destination at the end of three months, and purchased 250 bushels at $10 \mathrm{~s}$. per bushel. The grain was stowed in flat-bottomed boats which were laboriously propelled up the Mississippi River, up its tributary the Minnesota River, through Big Stone Lake, and then down the Red River. ${ }^{27}$ The Settlement was reached in June. The seed was immediately sown and the wheat-plants made a vigorous growth; but the grasshoppers again appeared, and it was feared that the crop would be destroyed for the third time. However, for some unexplained reason, the whole swarm suddenly disappeared early in the season, and did not return. Owing to the late sowing, the harvest did not ripen well. Nevertheless, it came to sufficient perfection for seed. ${ }^{28}$ After this the Red River never lacked seed-wheat again until the year 1868 when, for the second time, a mighty swarm of grasshoppers completely destroyed all the crops. The cost of the expedition to Prairie du Chien was tremendous, for it amounted to no less than $£ 1,040 .{ }^{29}$ However, it was not allowed to weigh on the settlers for it was charged to the estate of Lord Selkirk and paid by his executors. ${ }^{30}$ T'hether or not the new wheat brought from a distant part of the United States with so much toil and at so great an expense was a named variety or was simply called wheat, unfortunately, does not now appear to be known. ${ }^{31}$

27 G. Bryce, loc. cit., pp. 157-158.

28 A. Ross, loc. cit., p. 51.

29 Ibid.

30 C. Martin, loc. cit., p. 173.

$31 \mathrm{Dr}$. C. N. Bell has informed me that when he came to Winnipeg nearly fifty years ago, there was a tradition in the colony that a number of new weeds were introduced into the colony with the seedwheat from Prairie du Chien. Among these weeds the French-weed or Stink-weed (Thlaspi arvense) was especially mentioned. 
The crop of 1821 was not a large one and, after a portion of it had been stored as seed for the next spring, the remainder was found to be insufficient to supply the food requirements of the colony for the winter. The shortage was rendered all the more acute by the arrival of a band of emigrants from the Cantons of Switzerland. It was therefore found necessary to send some of the settlers to the haunts of the buffalo at Pembina. In the spring of 1822, these settlers returned and, during seed-time, the whole colony suffered all but absolute starvation. To such an extremity were some of the Swiss reduced that one of them gave a silver watch valued at five guineas for eight gallons of wheat, not to sow but to eat, another gave five shillings for six small fishes known as gold-eyes, and it is further reported that "one poor man, having nothing else, gave the very snuff out of his box for the head of a cat-fish." Thus ten years after the establishment of the Red River Settlement the colonists were still bearing great hardships. The first five years had been embittered by the enmity of the North-West Company, and the succeeding five years by unfavorable crop conditions. ${ }^{32}$

\section{The Hour-Glass}

During the early years of struggle against adversity, the colonists were prevented from suffering the direst want and actual starvation by the care of Lord Selkirk and his agents, who sent out to the Red River not only a supply of general goods, clothing, implements of husbandry, arms, and ammunition, but also a supply of oatmeal to fall back upon in the last extremity. These articles were kept in the colony store and supplied to the settlers by the Governor of the Colony. The store was grossly mismanaged, and

32 A. Ross, loc cit., pp. 55-60. 
one of the Governors, Alexander McDonell, was nicknamed the "grasshopper governor," as he proved as great a destroyer within doors as the grasshoppers had done in the fields outside. The Governor affected the style of an Indian viceroy but, when the puncheons of rum arrived from England in the fall, did not hesitate to carouse with his secretaries, assistant-secretaries, accountants, orderlies, grooms, cooks, and butlers. The liquor account was kept in a distinctly novel manner, grains of wheat being used for the purpose. The heel of a bottle was filled with wheat and set on a cask, the contrivance being called the hourglass. For every flagon drawn off, a grain of wheat was taken out of the hour-glass and put aside until the carousal was over. The grains were then counted, and the amount of expenditure ascertained. "From time to time," says Ross, "the great man at the head of the table would display his moderation by calling out to the butler, 'Bob, how stands the hour-glass?' 'High, your honor! high!' was the general reply; as much as to say they had drunk but little yet. Like the Chinese at Lamtschu, or a party of Indian chiefs smoking the pipe of peace, the challenges to empty glasses went round and round so long as a man could keep his seat; and often the revel ended in a general mêlée which led to the suspension of half-a-dozen officials and the postponement of business, till another bouse had made them all friends again. Unhappily, sober or drunk, the business was as fraudulent as it was complicated." On the arrival from England of Mr. Halkett, one of Lord Selkirk's executors and a staunch friend of the colony, Governor McDonell's stewardship was brought to a close and the celebrated hour-glass was used no more. ${ }^{33}$

33 A. Ross, loc. cit., pp. 63-68. 


\section{The Census of 1822}

A census ${ }^{34}$ of the Red River Settlement taken in the spring of 1822 throws an interesting light upon the state of the colony ten years after its foundation. The human population consisted of 681 persons, of which $23 \div$ were men, 161 women, and 286 children, bors and girls being exactly equal in number. There were 126 houses and 160 gardens. The livestock consisted of: 3 bulls, 45 cows, 39 calves and 6 oxen; 10 sheep and 1 ram; 12 pigs; and 78 horses. The seed sown in the spring of 1822 , reckoned in bushels, was as follows: wheat, $235^{15} / 16$; barley, $142^{22} / 32$; Indian corn, $12^{30} / 32$; potatoes, 570 ; and peas, $17 \%$. The books numbered 81 . The total value of the Settlement was estimated at $£ 4,620.0 s .5 d$., surely from our present point of view a very modest computation.

\section{Milling Operations}

In 1824, after a protracted struggle of twelve years, the Scotch settlers reaped their first truly satisfactory crop of grain. By this time the plow was being tried with considerable success and greatly lightened the work of preparing the seed-bed. The rields obtained were high, the returns for wheat being forty-four from the plow and sixty-eight after the hoe. ${ }^{35}$ At harrest time, the wheat was gathered with a sickle. It was then threshed with a flail and ground into flour with a handstone known as a quern. Several of these quems are still in existence, one being in the possession of the Ogilvie Milling Company of Winnipeg. Two others are at Lockport, one belonging to Mr. John MacDougal and the other to Mrs. J. E. MeAlister. About 1823, the two-horse treadmill was introduced; and 34 An unsigned abstract in the Selkirk Papers, spring, 1822. 35 A. Ross, loc. cit., p. 78. 
this was followed later by a Hudson's Bay wind-mill at Fort Douglas. The first millwright in the colony was Samuel Lamont, who arrived in 1813. Lord Selkirk, who sent him out, described him as one who "understands his

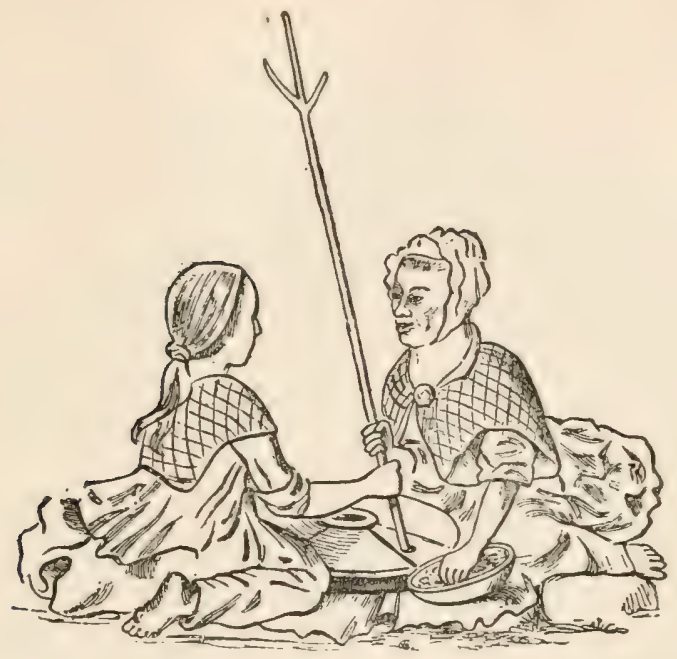

Fig. 2. Helırides women grinding with the quern or hand-mill. From E. 13. Tylor's Anthropology. Courtesy of Macmillan \& Co.

business although he certainly looks like a dull fellow." 36 It was Lord Selkirk's desire from the first that the Red River Settlement should produce enough flour not only to supply its own needs but also those of the Hudson's Bay posts. ${ }^{37}$ In 1814, he therefore instructed the Governor to pay the farmers at least two shillings a bushel for what they could spare and sent him a description of the most suitable method for grinding the wheat into flour. ${ }^{38}$ At ${ }^{36}$ Lord Selkirk in a letter to Miles Macdonell, April 12, 1814, Selkirk Papers.

37 Ibid.

38 Ibid. 
the same time, in connection with the raising of barley, Lord Selkirk referred to the possibility of erecting a distillery. ${ }^{39}$ In 1814 John Barleycorn was a king who little knew the contraction that was to take place in his dominions a century later.

\section{The Mice}

One of the most curious biological phenomena connected with the North-West is the periodic rise and decline in the number of rabbits and mice, with which is associated a corresponding rise and decline in the numbers of the furbearing animals, such as the mink, the lynx, the fox, and the wolf, which feed upon them. The mice in 1825 evidently attained a maximum in numbers, for Ross tells us that, in the autumn of that year, the fields, the woods, and the plains seemed literally alive with them. They attacked the grain after it had been stacked and almost totally destroyed it. The straw and even the very stubble itself was cut to pieces by them, and, for a time, it was feared that the new plague would be as calamitous as the grasshoppers. ${ }^{40}$ However, the next year the swarm of mice was found to have disappeared, and the fruits of the earth were no more threatened by them.

\section{The Great Flood}

In the fall of 1825 , a large party of half-breeds went south to pass the winter on the plains. About the twentieth of December there was an unusually heavy snowstorm which lasted for several days, in consequence of which the buffalo passed beyond the hunter's reach. Most of the horses died, and, before assistance could arrive, famine set

39 Ibid.

40 A. Ross, loc. cit., p. 97. 
in. Thirty-three lives were lost, and only with infinite difficulty were the survivors conveyed to the settlement.

The winter of 1825-26 followed a rainy season and was exceptionally severe. It began earlier and ended later than usual. The snows averaged three feet deep on the prairie and in the woods from three to four feet deep. The cold was intense, the temperature descending to 45 degrees below zero. The ice in the Red River became five feet seven inches in thickness. The spring of 1826 was late in coming. The wind blew from the south for several days together, and the sudden burst of warm weather which ensued rapidly melted the accumulated snows. Red Lake, Otter-tail Lake, and Lake Travers orerflowed their banks. On the 2nd of May, the day before the ice started to move in the Red River, the water rose nine feet in twenty-four hours. On May 4, the water orerflowed its banks and spread so fast that, before the settlers could fully realize what was happening, it had reached their dwellings. On May 5, the settlers abandoned their houses and sought refuge with their horses and cattle upon higher ground. A mighty lake was formed in which houses, barns, furniture, and moving blocks of ice were carried along to Lake Winnipeg. The height to which the water rose above the level of previous years was fifteen feet, and the water continued rising until May 21. Wheat which at the commencement of the flood had fallen to $2 s$. per bushel soon rose to $15 s$, or nearly double its normal price, and beef rose from $1 / 2 d$. per pound to $3 d$. On May 22 , the waters came to a stand and after a day or two began to fall. On the 15th of June, the settlers again drew near to their former habitations. They then broke up into two parties. One of them, comprising the Swiss emigrants, the de Meuron soldiers, and other reckless spirits, determined to try their fortunes elsewhere, and on June 24 took their de- 
parture for the United States. 'The other party, consisting of Scotch settlers, were not so easily chilled by disappointments and, without any hesitation, resumed work on their cheerless farms. The seeding season was already very advanced, yet barley, potatoes, and even a little wheat sowed as late as June 22 came to maturity. ${ }^{41}$

\section{Prosperity in 1829}

After the disastrous year 1826 which, however, served to purge the settlement of its human dross, conditions greatly improved, and by 1830 the colony was thriving as it had never done before. The saturation of the soil with the flood water was favorable to suceeding harvests, and several good crops were now reaped. Ross states that from a field sowed with 10 bushels he obtained 255 bushels; and that from another field, sowing $s$ bushels, which had been left fallow for two years rumning, during which it had been plowed three different times and then sown in drills, he obtained for a first crop 280 bushels. $^{42}$

The population now became increased by the arrival of a number of settlers who were of a much more desirable type than those who had left after the flood; and many new houses were erected to accommodate them. This rapid progress and the excellent crops soon fully restored confidence in the future of the colony. Governor Donald Mackensie, writing to Colvile in August, 1829, grew enthusiastic concerning the improvement which had taken place and in colorful langnage referred to: the corn " rich and flourishing," "the boundless prairie" with cattle like "herds of buffalo brousing." the groups of harmakers

41 A. Ross, loc. cit., pp. 98-107. Of the disastrous events in the year 1826, Ross, who was an eyevitness, gives a very vivid description.

42 Ibid., p. 112. 
"healthy and blooming," the "community of sentiments," the "stacks and laden carts straining the eve in countless succession," and to the "ensemble of landscape perhaps nowhere to be equaled." "I beg to congratulate you and all my employers," he ended, "on the prosperous state of the Colony." 43

\section{The Red River Flour}

Up to about the year 1831, the Hudson's Bay Company could never rely upon the settlers for a sufficient supply of flour for the needs of its serrants scattered through the West, and actually was obliged to import annually from Eneland, via the Hudson Bay, such articles of consumption as it needed. To encourage agriculture, Governor Simpson, the chief manager of the Company's affairs throughout Rupert's Land, promised to take all the Company's supplies from the colony. This ronsed the settlers to fresh activity and, for a time, all the wants of the Company were adequately met. No sooner was this done, however, than prices fell, flour coming down from $16 s$. to 11s. $6 d$. per linndred weight, butter from 1s. to $7 d$. per pound, and cheese from i $d$. to $4 d$. per pound. The market was becoming orerstocked, and the settlers found that the extension of their farming operations had male them but little better off. Just at this time, a great outcry was raised throughout the country against the quality of the produce: the flour was said to be "heaterl. somr, and altogether of so very bad quality as to be only fit to poison pigs," and the refinements of the English language were inadequate to condemn sufficiently the butter and the cheese. ${ }^{44}$

43 Chester Martin, loc. cit., p. 175.

44 A. Ross, loc. cit., p. 116. 
That the flour was not good, there can be no doubt. Its evil quality was largely due to the lack of the necessary conveniences for pursuing agricultural operations. "In the whole colony," says Ross, "there was not to be found either a smut-mill or fanning machine to clean the grain, and but few barns to thresh it in, and still fewer to dry it; much, therefore, of the grain had, of necessity, to be threshed on an ice-floor, in the open air, during all weathers, and then ground in a frozen state, and immediately packed in casks made of green wood, furnished by the Company itself." With such a mode of preparation, it was little wonder that the flour became heated and sour, and made unpalatable bread.

To improve the quality of the flour produced in the colony, Governor Simpson resolved to discontinue buying: flour from the settlers and to buy wheat instead. The wheat was then to be dried and milled under the direction of the Hudson's Bay Company. The price of the grain was fixed at $3 s .6 d$. per bushel, equivalent to $11 s$. $6 d$. per hundred weight, which had been considered by both parties a fair price for the flour. At the next harvest, which was below the average, the Company bought in from 8,000 to 10,000 bushels of wheat and kept it in their granaries for the winter. Unfortunately these buildings were too small, there was no space in which to shift the grain from place to place, and it had to be heaped up often four or five feet deep. The wheat had been bought by the measured bushel, and all that had been offered, good, bad, and indifferent, had been taken. Some of it had been threshed in barns and some of it on ice-floors in the open; and it was by no means free either from moisture or smut. On being left piled up in the granaries, the wheat naturally heated and became almost baked together. The rest of the story is best told in Ross's own words: "Large quan- 
tities of dried buffalo meat had been stored up in the same buildings, the daintiest fragments of which were carried off by the mice and mixed up with the wheat, making a compound of wheat, smut, icicles, dried meat, mice, and mice nests, all more or less heated together; the smell of which, without the hazardous experiment of tasting, was absolutely disgusting. In this state, despite all advice to the contrary, and the certainty of bringing disgrace upon the colony, the wheat was ground and the flour shipped off to the different trading posts. The writer, having a mill, was among those patronized on this occasion and can bear witness that the smell was intolerable. When the complaints of the victimized consumers had to be answered, the whole blame was laid upon the millers." 45

To grind its wheat into flour, the Hudson's Bay Company had employed twelve mills belonging to the colonists. The flour thus produced contained a large amount of bran, as is proved by the following analyses ${ }^{46}$ made by Governor Finlayson:

Pounds

Pounds of

Flour. of Bran.

No. 1. In 112 from John Vincent's mill was found........ 12

No. 2. In 112 from William Bird's mill was found....... 12

No. 3. In 112 from George Flitt's mill was found......... 12

No. 4. In 112 from Narcisse Marion's mill was found...... 14

No. 5. In 112 from Michel Klyne's mill was found........ 14

No. 6. In 112 from James Inkster's mill was found....... 14

45 A. Ross, loc. cit., p. 120.

46 Ibid., p. 121. Ross adds: No. 1 and 2. Half-breeds of English extraction. 3. An Orkney man. 4. A Canadian. 5. A German. 6. An Orkney-man. 7. A half-breed of Scotch extraction. 8. An Irishman. 9. A half-breed of English extraction. 10. A Scotchman. 11. A half-breed of Orkney extraction. 12. A half-breed of Canadian extraction. 
Pounds

Pounds

Flour.

Bran.

No. 7. In 112 from Thomas Logan's mill was found....... 14

No. 8. In 112 from Andrew McDermot's mill was found... 18

No. 9. In 112 from Thomas Bird's mill was found........ 20

No. 10. In 112 from Hugh Polson's mill was found........ 20

No. 11. In 112 from Robert Sandeson's mill was found...... 26

No. 12. In 112 from Cuthbert Grant's mill was found...... 28

\section{Windmills}

In the early years of the Settlement, Lord Selkirk sent out a windmill to replace the querns. This had cast rollers and machinery capable of working two pairs of stones; but, when it arrived, no one was able to set it in operation. It was therefore sent back to England and reshipped. At length, ten vears after its first arrival in the Colony, Lord Selkirl's executors sent out a Scoteh mill-wright named Mitchell to put it in order. His efforts having been successful, the windmill began to work in 1825. It had cost no less than $£ 1,500$. It was then sold to Mr. Logan for a fifth part of this sum, and he, having some knowledge of machinery, turned the mill to good account for many years. In the spring flood of 1852, its strong and lofty pillar resisted the high water and afforded protection to many of the settlers who sought refuge within its walls. ${ }^{47}$ After Logan's mill had proved a success, similar ones were erected; and windmills dotted here and there came to form an interesting feature of the landscape.

\section{The Experimental Farms}

On three oceasions before 1850 , an attempt was made to help the settlers by the institution of experimental farms; 47 Ibid., pp. 144-145. 
but all these farms failed, and they became known in the colony as the "three unfortunate sisters." 48

The first experimental farm was planned by Lord Selkirk and was called the "Hay Field Farm." A Scotch farmer named Laidlaw was sent out to take charge, but mismanagement ruined everything. "Barns, yards, parks, and houses of erery description," say's Ross, "were prorided; and yet all the time there was not an ox to plow, nor a cow to milk in the settlement. To crown the folly and extravagance of the undertaking, a mansion befitting a peer was built at an expense of $£ 600$, which at the moment of completion was accidentally burnt to ashes in a drunken frolic. After several years' labor, waste, and extraragance, every vestige of property on the farm had disappeared, the experiment having cost Lord Selkirk $£ 2,000$." 49 The project was abandoned in 1822 .

The second experimental farm was a favorite scheme of Governor Simpson, and greatly was he dejected by its failure. Its one contribution to the welfare of the settlers appears to have been the introduction of a fine stallion from England at a cost of $£ 300$, with a consequent improvement in the breed of horses. The management of the farm unfortunately was put into the hands of a fur trader who tried various experiments without success. Finally, after six years' trial, the farm was sold with a dead loss to the Company of $£ 3,500$." 50

The third experimental farm was organized by a committee in London, and Captain Cary, a half-pay officer, whose agricultural knowledge appears to have been more theoretical than practical, was sent out to take charge. Everything that money could procure was provided, but

48 Ibid., p. 212.

49 Ibid., pp. 77-78.

s0 Ibid., pp. 133-135. 
the settlers always had the better crops both in quantity and quality. The model farmers mowed down their fields of grain with the scythe in place of cutting it with a sickle, and gathered it with rakes instead of tying it into sheares. This practice, however, the settlers refused to follow. The dairy served to keep the Governor's tea-table in milk; but his butter and cheese were furnished by the settlers. After dragging out its existence for about ten years, the farm ceased to operate, and, when its stock and implements had been sold, the experimenters were losers by $£ 5,500{ }^{51}$

The Dominion Experimental Farms system was founded in 1888, and among the first branch farms to be established was one at Brandon in Manitoba. This experimental farm has been the scene of the carrying out of many important investigations both in respect to field crops and live-stock, and has contributed in no small degree to the progress of agriculture in the West. Lord Selkirk's belief in the value of an experimental farm has therefore been justified.

\section{The Bloody Flux}

In 1846, the Red River Settlement was terribly afflicted by a disease known to the settlers as the bloody flux. In January of that year the influenza raged, and in May measles broke out; but neither of these maladies proved very fatal. In June, however, the bloody flux began its ravages among the Indians of the White Horse Plains and soon spread with alarming rapidity and awful consequences to the whites. At the Settlement "there was not a smiling face in a summer's day," "hardly anything to be seen but the dead on their way to their last home, nothing to be heard but the tolling of bells, and nothing ${ }_{51}$ A. Ross, loc. cit., pp. 211-219. 
talked of but the sick, the dying, and the dead." On one occasion thirteen burials were proceeding at the same time. From June 18 to August 2, the deaths averaged seven a day, or 321 in all, so that the population was reduced by one person out of every sixteen. ${ }^{52}$ The Spanish influenza which became epidemic in the city of Winnipeg in the present year, 1918, serious though its effects have been, has not exhibited one-tenth the virulence of the bloody flux of 1816 , for out of a population of some 200,000 there have been fewer than 1,000 deaths, or about one death for every two hundred persons. There is every reason to believe that the bloody flux was due to insanitary living conditions. The disease itself, which is now sometimes called bleeding diarrhxa, was doubtless a form of dysentery and may have been caused by the waterinhabiting parasite Amoba histolytica, which was responsible for so many deaths to the soldiers of the British Empire during their gallant attack on the Gallipoli Peninsula.

\section{The Census of 1849}

A census taken in 1849 shows that by this time great progress had been made in the development of the colony. The population had grown to 5,391 persons. There were 745 houses, 12 schools, 7 churches, 2 water-mills and 18 windmills. The plows numbered 492, the harrows 576 , the carts 1,918 , the boats 40 , and the canoes 428 . The land under cultivation was upwards of 6,000 acres. The live-stock consisted of 1,095 horses, 990 mares, 2,097 oxen, 155 bulls, 2,147 cows, 1,615 calves, 1,565 pigs, and 3,096 sheep. ${ }^{53}$

52 A. Ross, loc. cit., pp. 362-363.

53 Ibid., loc. cit., p. 409. 


\section{Another Plague of Grasshoppers}

In the spring of 1852 and 1861 , the colony was again flooded by an overflow from the Red River, and scenes were witnessed recalling those of 1826. Grasshoppers laid waste the crops in $1857,1858,1864,1867$, and $1868.0^{54}$

The devastation caused by the grasshoppers in 1868 was as complete as in 1819. The insects arrived in $\mathbf{1 8 6 7}$ at the beginning of the harvest and, after greatly injuring the wheat and entirely destroying the oats and barley, deposited their eggs just as they had done in $1818 .{ }^{55}$ In 1868 the eggs hatched and the larvæ which emerged cleared the fields of every vestige of vegetation. "The multitude of insects," says Hargrave, "was so great as to render it difficult to convey an appreciable idea of their numbers to the minds of those absent from the scenes of their devastations. Piled in heaps about the walls of Fort Garry, they were carted away and burned up to prevent the effluvia from their decaying bodies contaminating the atmosphere during the stifling heats of an unusually warm summer." Threatened with absolute starvation, the colonists were obliged to appeal for help; and the appeal was not in vain. Letters were written to the Times with the result that the British public sent to the suceor of the colony the sum of $£ 3,000$. In addition, $\$ 12,000$ were collected in Canada and $£ 900$ in the United States of America. In the meanwhile, the Council of Assiniboia voted a sum of $£ 1,600$ for immediate expenditure as follows: $£ 600$ to purchase seed wheat, $£ 500$ to procure flour from the United States, and $£ 500$ for fishing tackle and ammunition. The flour to be conveyed to the colony was received by an agent at St. Paul and then transported over 54 J. J. Hargrave, Red River, Montreal, 1871, pp. 175-176, 446.

55 Ibid., p. 419. 
the plains during the winter by the laborious and expensive means of horse and ox sledges. There were 260 miles of journeying from St. Paul to Fort Abercrombie, and then another 250 miles from Fort Abererombie to the headquarters of the Settlement on the Red River. The transportation of the flour, however, was successfully accomplished, and the settlers, as they ate their bread in the winter of $1868-69$, were cheered with the thought of the warm sympathy which their needs had awakened in the great world without. ${ }^{56}$

\section{State of the Settlement in 1870}

After the IIudson's Bay Company altered its route for the importation of the goods intended for its trade from the old one of the IIudson Bay to that of St. Paul, a very considerable traffic by means of Red River carts grew up between St. Paul and the Red River Settlement. According to Hargrave, who wrote in 1871 , some 1,500 carts made the journey yearly and 500 carts twice a year. They carried furs to the south and brought back manufactured articles on the return journey. Three hundred carts also plied between the Settlement and the district of Saskatchewan. ${ }^{57}$ This contact with other civilized communities gradually became more intimate and the Settlement correspondingly less isolated.

In 1870 the total population, including white settlers,

${ }^{56} \mathrm{Ibid}$., pp. 446-449. In one item Hargrave is in error, for he states that the Canadian contribution to the relief of the Settlement was $\$ 3,600$. This figure is too small. Chester Martin, who has had access to the accounts, says that "Canadian cities and private individuals contributed more than $\$ 12,000$." Vide C. Martin, The Red River Settlement, in Canada and Its Provinces, Toronto, 1914, Tol. IIX, p. 68. Minnesota's contribution, according to Martin, was $\$ 5,000$.

57 Ibid., pp. 167-168. 
Indians, and half-breeds, was $12,800,58$ but the amount of land under cultivation was still very small. There was no market to supply except that at home and that provided by the requirements of the Hudson's Bay Company, so that there was no inducement to the settlers to extend their farming operations. The farms were all situated on the Red River between Upper Fort Garry and Lower Fort Garry, and along the northern bank of the Assiniboine River. Even as late as 1870, the possibility of growing cereals on the prairie more than two miles back from the rivers had not been tested. ${ }^{59}$ The first settlers on the open prairie appear to have been the Mennonites, who came to the southern part of the province of Manitoba from Russia in 1875. Among other things which the Mennonites brought with them was a variety of wheat known as White Russian, which was ultimately supplanted by Red Fife.

The first exportation of wheat to the East took place in 1876 and consisted of 857 bushels of Red Fife - all that could be obtained - which was required in Ontario for seeding purposes. The consignment left Winnipeg by steamer and was conveyed up the Red River to Fisher's Landing where it was transferred to a railway truck for carriage to Duluth. ${ }^{60}$

\section{Effect of the Revolution in the Milling Industry}

The extension of the cultivation of Red Fife and other hard red spring wheats in western Canada and the Great Plains region of the United States was profoundly influenced by the revolution which took place in the milling 58 Ibid., p. 174.

59 Ibid., pp. 176-177.

60 For a more extended account of this incident, vide Chapter III, Section XXIII. 
industry between the years 1870 and 1880. In 1870 there was introduced into Minnesota the first purifier, a device for separating branny particles from midlings and flour, which had been invented in France by Perrigault. Before the advent of the purifier, the method of milling was such that the intrinsic value of the flour of hard spring wheat was unknown and unsuspected: spring-wheat flour was regarded as far inferior to flour from winter-wheat on account of the fact that although it was strong and produced well-risen loaves, it was of poor color. With the coming of the purifier which was first used in connection with mill-stones and afterwards with chilled-iron rollers, all this was changed, for the new machine enabled the miller to grind from the hitherto despised hard spring wheat a product with the desired whiteness, which, on account of its strength, immediately commanded a price equal to the best flour from winter wheat. ${ }^{61}$ "This," says Edgar, "gave a great impetus to milling in the NorthWest, increased the demand for spring wheat, rendered valuable the crops of Minnesota, the Dakotas, and western Canada, and led to the agricultural development of that section of the western continent. Spring-wheat flour sprang into favor in America, and when introduced abroad, especially in the United Kingdom, won its way against all competition. In the end, the demand for it caused British millers to remodel their mills and grind a mixture of home-grown and American wheats." ${ }_{62}$ Had it not been for the invention of the purifier, it is certain that the growing of spring wheat in the West would have been greatly retarded, cereal breeding at Ottawa might not have been begun so early as it was, and Marquis wheat, to which the 61 William Edgar, The Story of a Grain of Wheat, London, pp. $155-156$.

62 Ibid. 
third Chapter is devoted, might never have come into existence.

The Riel insurrection which took place in 1869 , was occasioned by want of tact on the part of the Government at Ottawa in its dealings with the Red River settlers; and it was only brought to an end in 1870 by a military expedition sent out under the leadership of Col. Garnet Wolseley. ${ }^{63}$

In 1870 the Province of Manitoba was formed and became the fifth of the sisterhood of the Provinces of the Dominion. In the same year a census was taken of the village of Winnipeg, with the result that 215 persons were found to be residing within its boundaries.

\section{The St. Paul Railway}

Soon after Manitoba had been organized as a province, settlers began to pour into it from the south. Immigrants from Ontario and the Old Country were compelled to come through the United States to Chicago, then northwest to St. Paul, and then northwards across 450 miles of level prairie. For eight years a stream of immigrants made the long journey into Manitoba by wagon, by stage, by coach, and by Red River steamer; and great was the relief to the traffic when at last, in 1878 , the first railway entered the province from the south. This new means of communication gave a direct connection between St. Paul in Minnesota and the little town of St. Boniface on the right bank of the Red River. On arriving at railhead, the settler, in

$63 \mathrm{Cf}$. George Bryce, Sketch of the History of the City of Winnipeg and of the Four Provinces of Western Canada, in A Handbook to Winnipeg and the Province of Manitoba, British Association for the Advancement of Science, Winnipeg Meeting, 1909, Winnipeg, pp. $13-15$. 
order to get to Winnipeg, had merely to cross the river in a. ferry boat. ${ }^{64}$

\section{The Canadian Pacific Railway}

The St. Paul Railway was a great boon and formed a splendid link with the United States; but something still was lacking. The rising spirit of Canada, supported by the voice of Manitoba, demanded that an all-Canadian railway should be built across the continent, so as to give the West a direct connection with the East. This great project was eventually brought to a successful conclusion, with the result that in 1886 there took place an event of outstanding significance for the subsequent development of wheatgrowing in western Canada: there passed through Winnipeg on Dominion Day, July 1, the first through train from Montreal to Vancouver. Its engine, Canadian Pacific Railway No. 1, ran upon a line of steel destined to bear to the country's ports hundreds of millions of bushels of wheat required to satisfy the world's craving for bread.

A grain of wheat is a very tiny thing in itself, but the prosperity of western Canada is bound up with its existence; and it is not too much to say that without the grain of wheat in its collective form, the great and thriving city of Winnipeg, with its population of 200,000 souls, its imposing buildings, its fine streets, and its busy cosmopolitan life, would scarcely have advanced at the present time beyond the status of a small trading station. The growth of Winnipeg from a village of 215 people in 1870 to its present proportions has been due in large measure to the construction of the Canadian Pacific Railway, the connecting of the east and west parts of Canada by a band of steel. Through mile after weary mile for hundreds of miles was ${ }_{64} \mathrm{Cf}$. G. Bryce, loc. cit. 
the track pushed from the east, past lake and swamp and stream, onwards amid the lonely forests of Pine and Poplar, of Spruce and Birch, on, on, through all that long stretch of rocky bowlder-strewn country north of the Great Lakes which was swept bare of soil in the dawn of human history, onwards and ever onwards, until at last it reached the West. All the vast difficulties in the path of the engineers were overcome because the men bohind the C. P. R. were men of rision, men who could see in the mind's eve under the blue dome of heaven the golden grain which would come to clothe the fertile acres of the broad prairieland. Surely the brightest dreams of the founders of the C. P. R. have been amply justified by events.

The completion of the eastern half of the Canadian $\mathrm{Pa}$ cific Railway immediately provided that direct connection with the Old Country market for which Manitoba had been longing; and soon the agricultural progress and prosperity of the West were assured. The tide of immigration grew ever stronger and Winnipeg became the great gateway to the new Land of Promise. The buffalo disappeared, the Indian gave place to the white man, and vast tracts of the virgin prairie were turned with the plow. The wheat of the prairie provinces, on account of its high quality, acquired universal fame, and Canada came to be called the Granary of the British Empire. How well that Granary served the cause of the Allies in its time of trial needs no telling, for it is known to the whole world. 


\section{CHAPTER II}

\section{Wheat in Westerin Canada}

\section{Some Crop Statistics}

THE rapid progress made by western Canada in recent years is reflected by the crop returns. In 1904 the wheat crop in Manitoba and Saskatchewan was only $56,000,000$ bushels, and the raising of cereals in Alberta was then in its initial stages. In 1906, the wheat crop of Manitoba, Saskatchewan, and Alberta had risen to $102,000,000$ bushels. In 1913, this was about doubled and amounted to $209,000,000$ bushels. In 1915 the wheat crop in the Prairie Provinces was produced under exceptionally favorable weather conditions and was a most extraordinary one. The Dominion Census Burean estimated it to be $360,000,000$ bushels. When it is borne in mind that in 1915 much less than one-half of the good wheat land of the West had as yet been broken by the plow, the optimism of western Canadians in the future of their half of the Dominion seems to be well justified.

Owing to the development of the West, Canada has now attained a very important place among the commonwealth of nations as a grain-producing country. Referring to the great crop year of 1915, Mr. W. E. Milner, as retiring President of the Winnipeg Grain Exchange, in September, 1916, made the following remarks: "This has been one of the most phenomenal years in the history of the grain business in the Dominion of Canada. Our farmers, hav- 
ing been blessed by the hand of Providence, produced the largest crop ever grown in this country and, now that the final figures are available, we find that our wheat crop reached the enormous total of $376,448,400$ bushels; our oat crop, 389,000,000 bushels ; barley, 39,202,000 bushels ; and our flax $6,000,000$ bushels, making a grand total of $810,650,400$ bushels of grain." 1

The crops for 1916, 1917, and 1918 have not been nearly as good as those of the banner year 1915. Nevertheless, during this period, in the Prairie Provinces, the wheat crop on the average has been well in excess of $200,000,000$ bushels.

The chief wheat-growing province is now Saskatchewan, after which comes Manitoba and then Alberta, as is shown by the following figures for spring wheat for the year $1915:^{2}$

Acreage and Yield of Wheat for 1915

\begin{tabular}{l|c|c|c}
\hline & Acreage & Bushels & $\begin{array}{c}\text { Yield } \\
\text { per acre }\end{array}$ \\
\hline Saskatchewan .... & $6,884,874$ & $173,723,775$ & 25.23 \\
Manitoba ....... & $3,664,281$ & $96,662,912$ & 26.40 \\
Alberta ........ & $\mathbf{1 , 6 3 7 , 1 2 2}$ & $\mathbf{5 8 , 8 3 0 , 7 0 4}$ & 35.93 \\
\hline
\end{tabular}

The average annual yield of wheat in bushels per acre in the principal wheat-growing countries of the world, for the five consecutive years $1909-13$, was as follows: ${ }^{3}$

1 W. E. Milner, President's Address, Eighth Annual Report (new series) of the Winnipeg Grain Exchange, Winnipeg, September, 1916, p. 24.

2 Supplement to the Cereal Maps of Manitoba, Saskatchewan and Alberta, issued from the Natural Resources Intelligence Branch of the Department of the Interior, Ottawa, 1917, pp. 4, 6, 8 .

3 Ibid., p. 13. 
WHEAT IN WESTERN CANADA

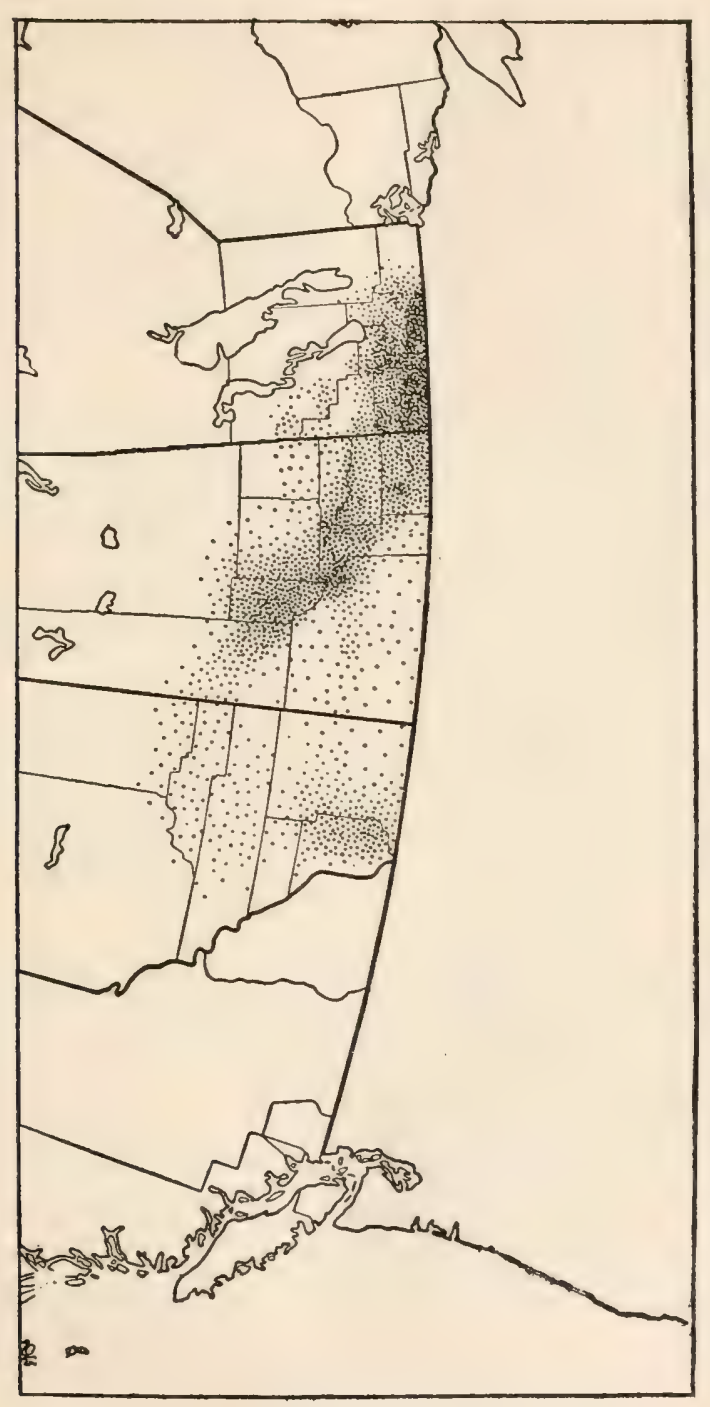

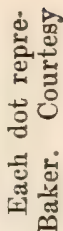

छु

ت

تृ

$\Rightarrow$

क्षै

近

$\Xi 0$

$\stackrel{D}{\circ}$

$\stackrel{3}{0}$

$=0$

$\approx$

方茫

$\stackrel{1}{1} \cdot \frac{1}{2}$

ํㅣㄹ

उ 1

उ

링

틀

5 을

유용

d0 24

त्य $\rightarrow 0$

की है

फै 하월

- 8

होం है

\&

ธิ ค

त्व क्ष

光

है क

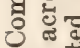

ल

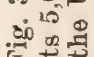

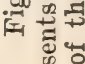


Average Yield of Wheat in Bushels per Acre Yield per acre

United Kingdom ... 31.9 Germany ........ 31.8 Austria .......... 20.2

Canada ......... 20.0

France ........... 19.1

Hungary ........ 18.8

Yield per acre
United States ..... 14.6

Australia ........ 13.2

British India . . . . 11.9

Russia ......... 10.8

Argentina ...... 9.9

from which it will be seen that the fertility of the soil in Canada has exceeded that of the United States by 5.4 bushels per acre but has been considerably less than that of the United Kingdom and Germany.

The average yield of spring wheat per acre for the Prairie Provinces for the ten-year period, 1908-17 inclusive, was as follows: ${ }^{4}$

Average Yield of Spring Wheat in Bushels per Acre Manitoba .................17.75 bushels

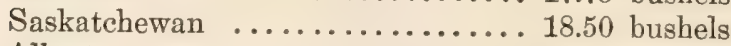
Alberta ................ 22.50 bushels

Upwards of nine-tenths of Canada's wheat is produced in the Prairie Provinces. These provinces, in the five years, 1913-17 inclusive, produced 1,283,000,000 bushels of wheat, whereas the rest of Canada in the same period produced only $118,000,000$ bushels. ${ }^{5}$

In per capita production of wheat Canada leads all countries. This is due to the smallness of her population relatively to the vastness of her acreage sown to wheat. The

1 Monthly Bulletin of Agricultural Statistics, Ottawa, August, 1918, pp. 222-223.

5 The annual figures upon which this calculation is based are given in a foot-note in the last Section of Chapter III. 
following have been the figures for the production of wheat for every man, woman and child in a few leading countries: Canada 32 bushels, Argentina 25 bushels, Australia 17.5 bushels, Rumania 14.5 bushels, Bulgaria 12.5 bushels, France 8 bushels, the United States 7.5 bushels, and the United Kingdom 1.5 bushels. ${ }^{6}$

Canada is a most extravagant user of wheat. For seed and other purposes she has used about 16.5 bushels per capita or about half what she has produced. The next countries making the freest use of wheat are: Argentina 11 bushels per capita, France 9.5 bushels, Italy and Australia 7.5 bushels, and the United Kingdom 7 bushels. ${ }^{7}$

Canada leads all other countries in the difference between her per capita production and consumption of wheat, and this, combined with her vast wheat crops, puts her in a very favorable position as a wheat-exporting country. In 1913 , the year before the war, when reliable statistics could still be obtained for all countries, the exports of wheat (including flour reduced to grain) from the twelve most important countries were as follows: ${ }^{8}$

Exports of Wheat in Bushels, 1913

Bushels

Bushels

United States ... 154,760,000 Roumania .... 54,203,000

Canada ....... 151,975,000 Australia ..... 53,207,000

Russia ....... 130,596,000 Germany ..... 29,638,000

Argentina ..... 109,637,000 Belgium ...... 15,898,000

Netherlands .... $64,501,000$ Bulgaria ...... $11,456,000$

British India ... 5 54,711,000 Austria-Hungary $\quad 1,730,000$

from which it is obvious that Canada stood second in the

6 V. C. Finch and O. E. Baker, Geography of the World's Agriculture, Washington, 1917, figures read from the diagram in Fig. 11 , p. 14.

7 Ibid.

S Supplement to the Cereal Maps of Manitoba, etc., loc. cit., p. 14. 
list, exporting only slightly less wheat than the United States.

In the year 1915-16, the world's exports of wheat were serionsly disturbed by the war. In that year, Canada had an immense surplus of wheat and took the premier position as a wheat-exporting country, surpassing even the United States. The exports of the four leading nations for 1915-16 were as follows: ${ }^{9}$

Export of Wheat in Bushels, 1915-16 Bushels

Bushels

Canada ...... 267,766,000 Argentina ..... 91,390,000 United States ... 239,526,000 Australia and

New Zealand .. 63,249,000

So far as the total production of wheat is concerned, Canada is still far behind several other countries, notably the United States, the Russian Empire, British India, and France, as will be seen from the following statistics of wheat production which are given as the average for the three-year period 1911-13 inclusive: ${ }^{10}$

\section{Amount of Wheat Raised in Bushels}

Bushels

Russian Empire

United States. .

British India...

France .........

Austria-Hungary

Canada......

Carried forward $\overline{2,601,951,600}$
$727,133,300$ Brought forward 2,601,951,600 $704,995,000$ Italy $\ldots \ldots \ldots \quad 190,840,000$ $369,612,300$ German Empire $160,236,700$ 324,136,700 Argentina .... 155,828,300 $247,141,000$ Australia ..... $88,961,000$ 228,933,300 United Kingdom $61,297,300$ Japan ...... 26,305,300 Other Countries $527,589,700$

$$
\text { Total .... } 3,813,009,900
$$

From these figures one may draw the conclusion that, be9 Ibid., p. 15.

10 Geography of the World's Agriculture, loc. cit., p. 8. 
fore the war, Canada's fraction of the total wheat production of the world was less than one-sixteenth of the whole.

In the year 1918, the farmers of both Canada and the United States, with a view to winning the war, made a special effort to increase the wheat crop, with the result that the combined wheat harvest of the two countries amounted to more than $1,100,000,000$ bushels. The following were the crops resulting from the "food offensive" as estimated in October : ${ }^{11}$

$$
\begin{aligned}
& \text { United States ........... 918,920,000 bushels } \\
& \text { Canada ............ 210,000,000 bushels }
\end{aligned}
$$

In this competition to succor the Allies, Canada was unfortunately handicapped by a prolonged drought, whereas in the United States the weather conditions were about normal. Thus it came to pass that in 1918 the United States produced upwards of four times as much wheat as Canada. However, there is still very much good wheat land in western Canada untouched by the plow, and some day Canada may produce more wheat than the United States. It is even possible that at no very distant date the United States may look to her northern neighbor for a large part of her daily bread.

\section{Wheat Growing ${ }^{12}$}

Winter wheat has a higher yield than spring wheat, wherever it can be successfully grown. However, on ac-

11 The United States figures are taken from the Ilonthly Crop Report for October, 1918, issued at Washington, and giving indications as for October 1 ; and the Canadian figures are taken from a press bulletin issued Oct. 31 by the Dominion Census Bureau.

12 For valuable assistance in writing this Section, I am indebted to Professor John Bracken of the Field Husbandry Department of the University of Saskatchewan. 
count of climatic conditions, very little winter wheat is grown in western Canada. The following Table shows the acreage devoted to spring wheat and winter wheat respectively in the three Prairie Provinces in the year 1918: ${ }^{13}$

Number of Acres Devoted to Spring and Winter Wheat in 1918

\begin{tabular}{|c|c|c|}
\hline & $\begin{array}{l}\text { Spring } \\
\text { Wheat }\end{array}$ & $\begin{array}{l}\text { Winter } \\
\text { Wheat }\end{array}$ \\
\hline $\begin{array}{l}\text { Alberta } \ldots . . . \ldots \ldots \\
\text { Saskatchewan } \ldots \ldots \ldots \\
\text { Manitoba } \quad \ldots \ldots \ldots \ldots\end{array}$ & $\begin{array}{l}3,187,000 \\
9,101,000 \\
2,616,000\end{array}$ & $\begin{array}{r}58,000 \\
2,000\end{array}$ \\
\hline Total ........... & $14,904,000$ & 60,000 \\
\hline
\end{tabular}

From this Table it is clear that such winter wheat as is grown at all in the West is chiefly produced in Alberta, and that the acreage devoted to winter wheat in the three Prairie Provinces taken together amounted in 1918 to only two-fifths of 1 per cent. of the total wheat acreage. Western Canada, therefore, as a whole, is a spring-wheat region. The climatic factors which tend to kill winter wheat are: (1) very low temperatures during the winter, (2) the relative absence of snow locally, (3) alternate freezing and thawing in spring, and (4) drying winds in spring.

The wheats sown in the spring are hard red varieties, the chief sorts being Marquis and Red Fife. The winter wheats, sown in the autumn, are chiefly Turkey Red and Kharkov. In dry parts of southern Alberta and southern Saskatchewan durum wheats are grown to a very small extent, but their culture may be considerably increased in the future.

The virgin prairie is usually broken in the month of June. Its surface is then cultivated and left uncropped 13 Monthly Bulletin of Agricultural Statistics, Ottawa, August, 1918, pp. 222-223. 
until the following spring. Thus the prairie grasses, etc., are prevented from growing and using up moisture, and the moisture is stored and conserved in the newly-broken land.

After one or more crops have been taken from the land subsequently to new breaking or summer fallowing, the land is prepared for the next crop by fall or spring plowing, by disking, cultivating, or, in some cases, by seeding on the untilled fields without any previous cultivation. Fall plowing is the most common practice but, in the dryer areas, spring plowing is sometimes carried out instead. The disadvantage of spring plowing arises from the delay which is involved in putting in the seed: spring plowing necessitates late sowing, late sowing is followed by late ripening, and late ripening of the grain increases the danger to which the crop is exposed from early fall frosts. In some areas where plowing is not considered necessary but where some form of surface tillage is deemed advisable, the stubble fields are disked or cultivated either in the fall or the spring. Sowing on untilled stubble fields, while not a general practice, is frequently carried out on land which is free from grass and weeds and the surface of which in the spring is found to possess a natural mulch or loose top layer of soil forming a natural seed-bed. In some districts, where untilled fields are sown, the stubble which holds the snow during the winter is burned off in the spring before seeding.

Until recently, but little or no attempt was made to apply manure or fertilizers to the land, and the grain fields were cropped year after year without anything being added to them. Of late, however, with the introduction of mixed farming, farm-yard manure has come to be more commonly used, particularly on the lighter soils. The manure is spread upon the summer fallow, root-grounds, etc., some- 
what thinly by means of a machine known as a manure spreader. This practice has been found to increase the yield of the crops on soils which have long been cultivated and thus to add to the profits of farming. It is, therefore, doubtless destined to be much more generally adopted in the future.

On account of the low rain-fall, moisture limits the yield of grain per acre. The bare fallow, or some modification of it, is therefore resorted to once in from two to five years, more often in the dryer districts and less often in the more humid ones. The summer fallow is the basic practice of dry farming. Its purpose is to store moisture in the soil by preventing its utilization by growing plants, and by conserving it in the soil by means of a soil mulch created by surface tillage. The surface tillage breaks the capillary tubes in the soil and so lessens evaporation.

In older districts, the summer fallow has a double function, for it is not only used to conserve moisture but also to control weeds. Among the annual weeds which have proved to be pests are Wild Oats (Avena fatua) and various members of the Mustard family; and, among the perennials, Sow Thistle (Sonchus arvensis), Canada Thistle (Cnicus arvensis), and Quackgrass (Agropyron repens). The very dry parts of southern Alberta and Saskatchewan are troubled with the Russian Thistle (Salsola Kali). Practically all of the noxious weeds of the West have been introduced either directly or indirectly from Europe.

Seed-wheat, before being sown, is usually cleaned by passing it through a fanning mill which, by means of sieves and screens and a blast of wind, removes the weed seeds, smut-balls, and other impurities, and also small and shrunken kernels of wheat. The seed wheat is then subjected to treatment with formalin, which is a 40 per cent. solution of formaldehyde. This is mixed with water in 


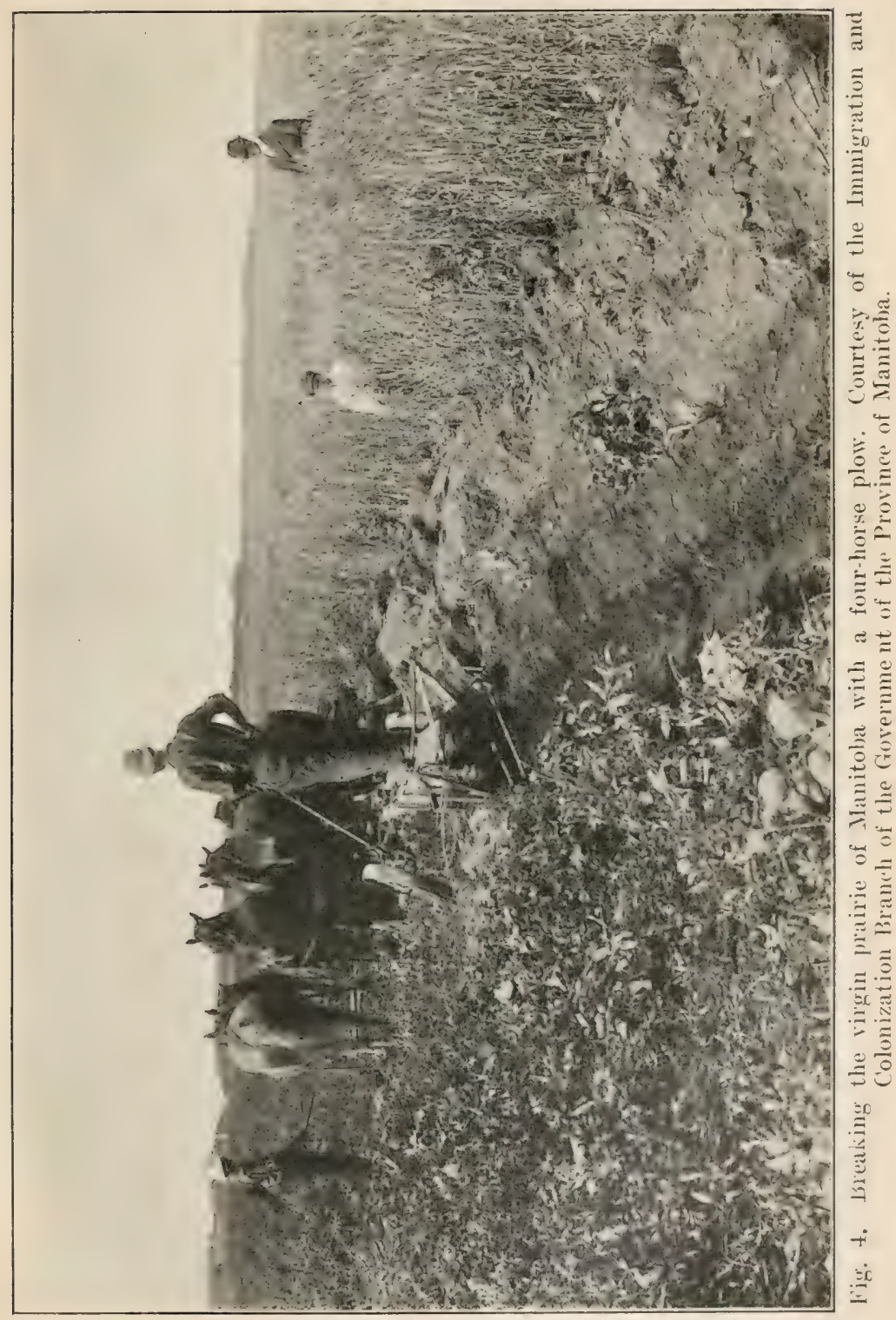




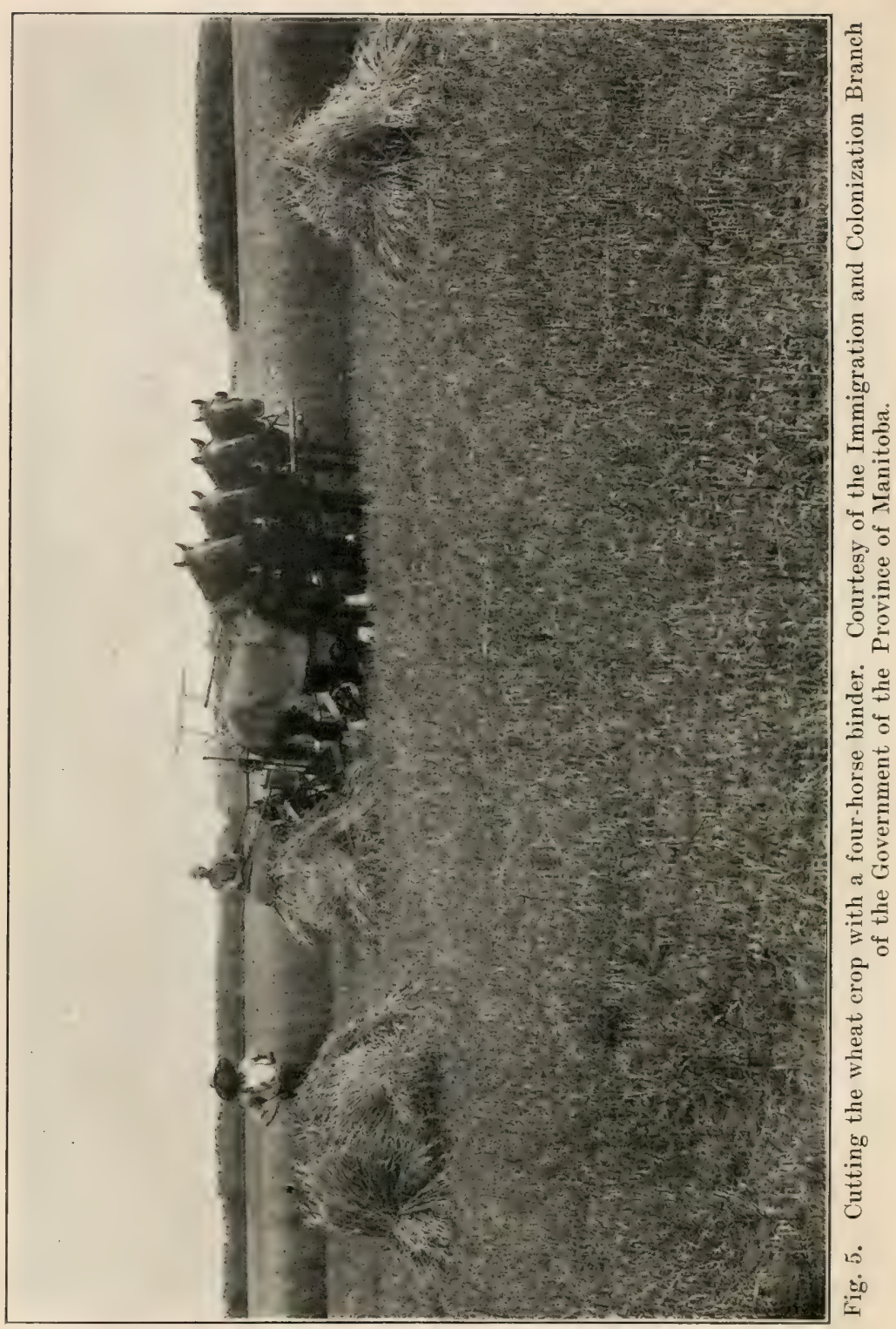


the proportious of one pound of formalin to forty gallons of water, and the mixture is then sprayed carefully over the seed or the seed is passed through the liquid by means of a smut machine. The purpose of this treatment is to kill any spores of the Stinking Smut Fungus (Tilletia fotens) which may be clinging to the kernels and which, if not destroyed, might germinate on the kernels in the soil, infect the seedlings, and cause smut-balls instead of sound kernels to be produced in the heads of the diseased plants. When there is any doubt as to the germinating ability of seed-wheat, the wheat is tested for germination either at home on the farm or in seed-testing laboratories provided by the Dominion or Provincial Departments of Agriculture.

The seed-wheat is sown by using large drills which are from eight to ten feet wide and which are drawn either singly by a team of four or more horses, or several together by an engine driven by gasolene or kerosene. These drills are so constructed that they force the seed evenly into the ground in rows which are from six to seven inches apart. The depth of sowing can be regulated and is usually from one to three inches below the surface. Seeding is usually completed between the middle of $A$ pril and the tenth day of May, April seeding being preferred when soil and climatic conditions permit of its being undertaken. The seed is sown at the rate of from three-quarters to two bushels per acre, the smallest quantity being used on the lighter soils in the dryest districts and the largest quantity upon the heaviest and richest soils in the more northerly humid districts. Under most conditions, the amount of seed usually sown is between one and one and a half bushels.

The wheat grower endeavors to prepare the land to be sown so that it shall be well stored with moisture, free from weeds, firm, and mellow. After seeding in such soil at a 
depth of from one to three inches, the depth varying with the soil's moisture contents, the land is generally firmed down by using a packer and then harrowed to create a mulch to lessen the evaporation of moisture.

The seedlings appear above the ground in from four to ten days after seeding, the period before emergence varying with conditions of moisture and temperature. In some places, the land is again harrowed after the plants have appeared above the ground, the purpose of this second harrowing being either to kill the small weeds that may appear at this time or to replace the mulch which may have been destroyed by rains.

The crop usually heads out during the first half of July and ripens between the tenth of August and the twentieth of September.

The crop is harvested slightly before it has attained perfect maturity by means of self-binders. These machines are hauled either by teams of four or six horses, or a number of them may be drawn by a tractor. Each binder cuts a width of from six to eight feet and, at the same time, ties the grain into bundles or sheaves. The sheaves measure from ten to twelve inches in diameter and, as soon as they have been tied, are thrown to the ground. They are then placed in stooks or shocks by men who follow the binders as closely as possible. The purpose of stooking is threefold: (1) to assist the drying or curing of the sheaves, (2) to lessen the danger to the grain of serious injury from weathering, and (3) to facilitate the further filling of the grains in the heads.

The grain is separated from the straw by means of large threshing machines driven by tractors and having a capacity of from 500 to 2,000 bushels per day. In the past, the straw on the large wheat farms has been considered to be a useless by-product, and the great straw piles which dot the 


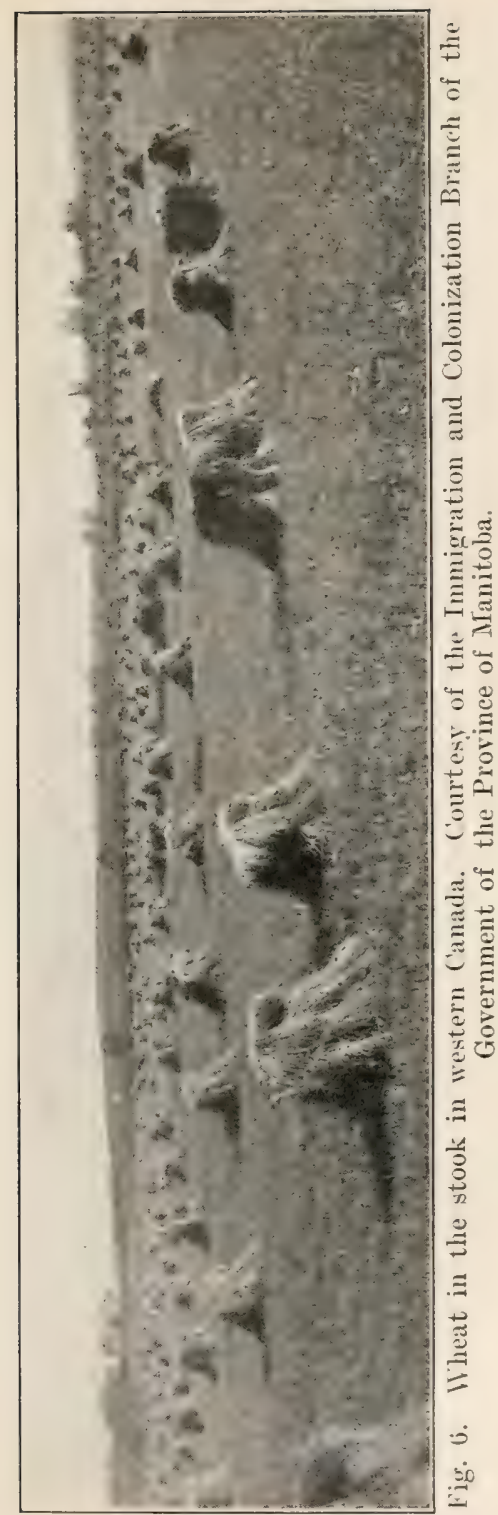




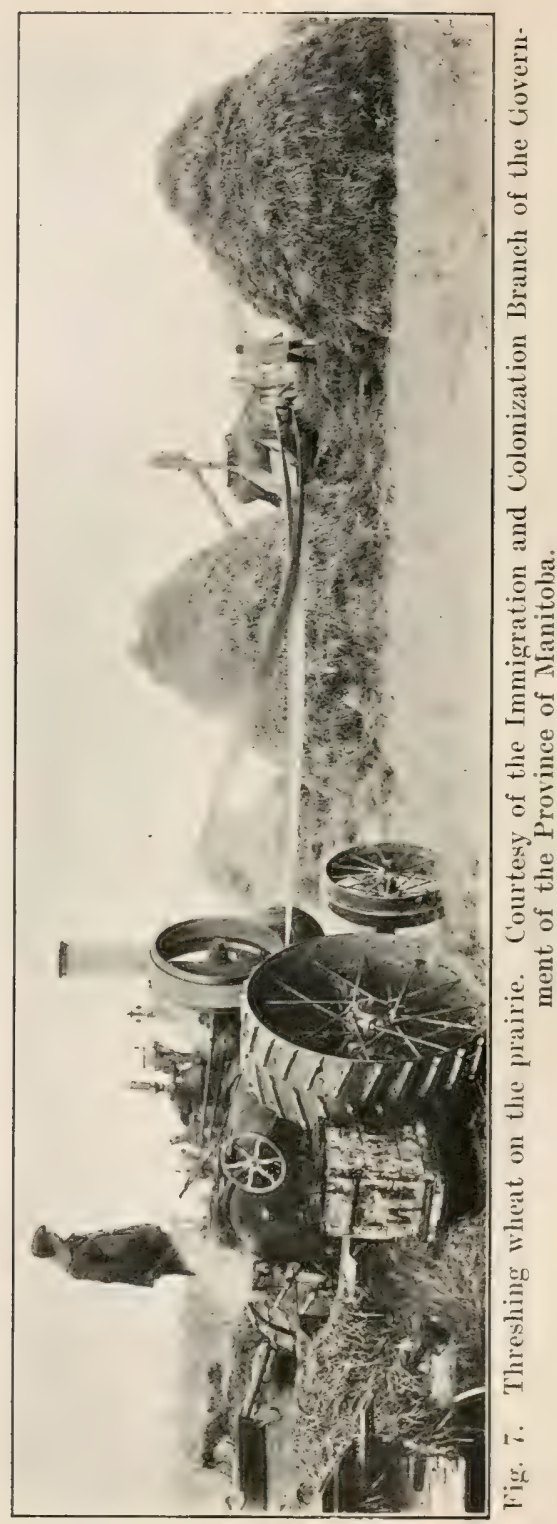


prairie after the threshing season (except for small portions saved for bedding horses, feeding, etc.) have usually been burned. The straw-pile fires reflected against the clouds at night in the autumn are well known everywhere in the West and form a strange and unexpected sight to newcomers from Europe where straw is of so much value. The recent development of mixed farming, however, offers in western Canada an opportunity for the utilization of straw to a much greater extent than hitherto as roughage for stock feed.

On large farms, the threshing is done directly from the stooks which are hauled in wagons from the places in the fields where they were set up straight to the threshing machines. The stooks may be loaded on to a wagon mechanically by means of stook-loaders, or they may be pitched by men into bundle racks. The threshing is carried out as soon as possible after the bundles have become sufficiently dry to pass through the machine without difficulty and after the grain has become sufficiently dry to be safely stored in bulk. If threshed when too moist, the grain may heat in storage and thereby be injured for commercial purposes. On the smaller farms, when for any reason threshing may be delayed, stacking is sometimes resorted to. This permits of fall tillage being undertaken at once and provides safe storage for the sheares until a threshing machine becomes available.

The harvesting and threshing season is the busiest part of the year in western Canada. To assist in relieving the labor shortage which is always felt at this time, some 20,000 to 30,000 extra harvesters are annually brought to the Prairie Provinces from the east of the Dominion and from the United States.

The grain, after it has been threshed, may be stored in temporary granaries on the farm or it may be hauled at 
once from the threshing machine to the country elevator or to a loading platform on a railway siding.

In the West, the standing crops are sometimes destroyed locally in summertime by violent hailstorms which in extreme instances have been known to rain down hailstones the size of hens' eggs. ${ }^{14}$ Usually the area ruined by a hailstorm is several miles in length but seldom more than a mile in width. To compensate for the destruction wrought by the ice-balls, a system of coöperative hail insurance has been introduced in Saskatchewan and Alberta, and many private hail insurance companies also carry on business in all parts of the West.

The western plains, in general, are very level and free from large trees, and hence are easy to break with the plow. The soil is thick and rich in humus and gives a good crop from the first. The chief difficulties of wheat raising arise from temporary droughts in summer, drying winds, early fall frosts, occasional severe attacks of the Black Stem Rust disease, and the already mentioned local hailstorms. Rain, however, seldom falls in too large a quantity and the weather during the harvesting and threshing season is usually dry and bright. There is no more exhilarating sight in the West than the prospect of the binders at work on the sea-wide, sky-skirted prairie, with the golden grain gleaming under the August sun and above and about all the cloudless blue dome of heaven. And when the last sheaf has been cut and the binders are silent,

14 This is no exaggeration. Photographs showing hailstones and fowls' eggs of equal size were exhibited by Professor J. W. Shipley to the Physics section at the Winnipeg meeting of the British Association held in 1909. Tide J. W. Shipley, On the Size of Hailstones observed during a storm in Western Canada, Reports of the British Association, 1909, p. 400. Some of the hailstones "were larger than hens' eggs. At the center of one hailstone a small black fly was found." 
how splendid is the view across the gently rolling stubble fields: stook beyond stook, stook beyond stook, for a quarter of a mile, for half a mile, and still more stooks as far as the eye can see, stooks cresting the distant horizon, ten thousand stooks all waiting to be threshed and each with its promise of bread, the gift of the New World to the Old. The unbroken expanses of the prairie create within one a sense of freedom which is best known only to those who dwell far from crowded cities, who plow and sow and reap, and whose daily toil causes them to commune unconsciously with Nature and thus to absorb something of her simplicity and her charm.

\section{'III. The Great Wheat Funnel}

In order to meet the ever-growing requirements of western Canada for travel and transportation, a complex system of railways has grown up with ramifications extending for many thousands of miles. The principal railroads tapping the wheat-lands are the Canadian Pacific, the Canadian Northern, and the Grand Trunk Pacific. Their main lines all focus upon Winnipeg so that this city has become, as it were, the converging point of a great wheat funnel, the spont of which leads to the water-front of Lake Superior. Through Winnipeg, each working day of the crop year 1915-16, on the average, there passed more than one thousand cars of wheat. ${ }^{15}$ The accompanying diagram (Fig. 8) shows the eastbound movement of western Canada wheat in the calendar year 1913. An inspection of it reveals the fact that most of the 1913 wheat, after passing by rail from Winnipeg to Port Arthur and Fort William, was conveyed by water to Montreal and Buffalo,

15 W. E. Milner, President's Address in Eighth Annual Report of the Winnipeg Grain Exchange, September, 1916, p. 26. 


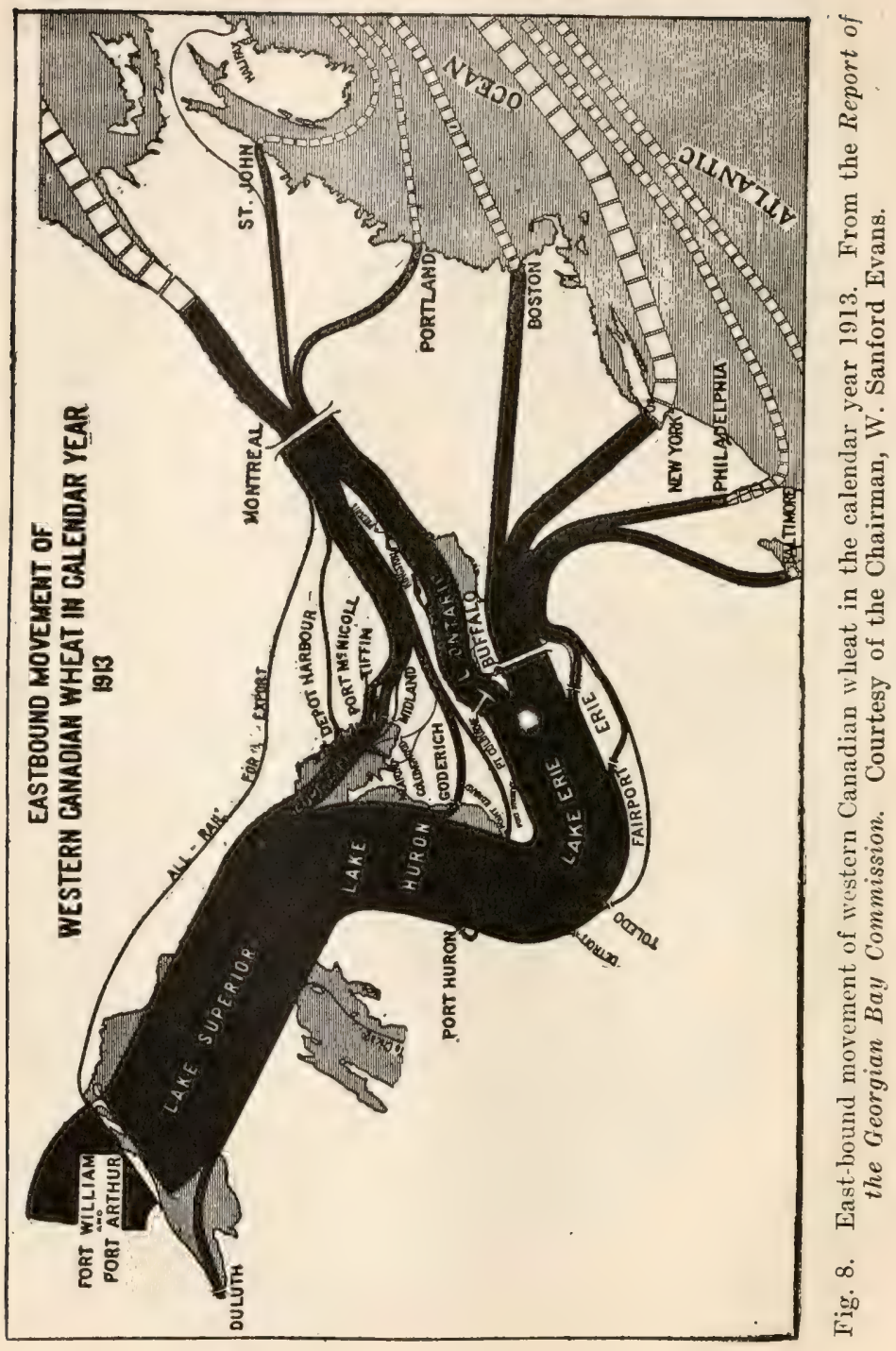


and that from these two latter cities it was then dispatched to the Atlantic Ocean via the St. Lawrence River or by routes leading to the ports of St. John, Halifax, Portland, Boston, New York, Philadelphia, and Baltimore.

\section{The Hudson Bay Railway}

In 1811, the Selkirk settlers entered Canada via the Hudson Bay, and the Bay remained for many decades the almost exclusive means of communication between the Red River Settlement and the British Islands. Through the Bay, as we have seen, came with the settlers the first seedwheat sown in western Canada; and through the Bay sailed each year, for nearly two centuries, the rich argosies of the Hudson's Bay Company, outward bound with great cargoes of fur and inward bound with foor-stuffs and manufactured goods. Shortly before 1870, the Hudson's Bay Company, taking advantage of the improved means of transportation in the Great Plains region of the United States, changed its trading route from the old one of the Hudson Bay to a new one passing south through Winnipeg. Thus it came about that for many vears the icy waters of the Hudson Bay were almost deserted by commerce. However, at the present moment, there is being built the Hudson Bay Railway which, in all-Manitoban territory, will give direct communication with the sea. This new line is to pass from The Pas to Port Nelson, a distance of 410 miles, of which 320 have already been completed. In the near future it is doubtless destined to carry to the seaboard a large amount of grain raised in northern Saskatchewan and Alberta. For the Province of Manitoba, the prospect, for at least four months in the year, of a shorter sea route to the British market than that from 
New York, marks a curious return to the historic conditions which were so familiar to the Selkirk settlers.

\section{The Shipment of Bull: Wheat Through the Panama Canal}

The opening of the Panama Canal has presented the possibility of shipping Canadian wheat to Europe from ports on the Pacific Coast. Howerer, until a year ago, no attempt to ship wheat in bulk vin the Panama Canal had been made, and it was not known whether or not bulk wheat could be safely transported through the tropies by this route without arriving at its destination in a heating condition. ${ }^{16}$ Dr. F. J. Birchard and Mr. A. W. Aleock, of the Dominion Grain Researeh Laboratory, therefore carried out a test experiment on bulk shipment in the fall of 1917.

One hundred thousand bushels of wheat for shipment were collected at various points in Alberta, graded by government inspectors, carefully tested for moisture, and then stowed in bulk in the hold of a steamer at Vancouver. The forward hold, into which the main bulk of the wheat was loaded, was one hundred feet long, fifty feet wide, and eighteen feet six inches deep. Each parcel of wheat of a particular grade, after being delivered to the vessel, was trimmed so that its surface was practically horizontal, and then separating cloths were spread over the top so as to divide it from the succeeding layer. Rows of electrical resistance thermometers were embedded in each layer of the wheat so that all changes of temperature in every part

16 For a number of years wheat has been shipped south from Seattle and Portland (Oregon) round the Cape to Europe in bags. Doubtless, however, the ventilation of wheat in bags is better than that of wheat in bulk. Wheat is shipped in bags from Australia and India to England. 
of the cargo could be observed by instruments on deck. One of the experimenters accompanied the boat from Vancouver down the Pacific Coast, through the Panama Canal, and across the Atlantic to London, the vovace occupying three and a half months. The shipment of the wheat was successfully made, for the Superintendent who supervised the discharge of the wheat at London reported that only 160 bushels, or less than 0.2 per cent. of the total cargo, had been damaged. It is evident, therefore, that bulk wheat, although subjected to a much higher temperature and to a much longer voyage when transported to England by the Panama route than when transported by the usual routes from the Atlantic coast, can yet be safely brought to its destination. Whether or not the new route for shipping wheat will be much used in the future is uncertain; but it seems not unlikely that a portion of the wheat produced in northern Alberta may be more cheaply transported by this route than by any other.

\section{Elevators}

To store the grain produced on the farm before it can be exported or otherwise used, special warehouses, known as elevators, are provided. The wheat is elevated into these buildings by machinery and deposited in bins. The bottom of the shipping bin is always situated at some distance above the level of the ground and opens into a movable spout on the exterior of the elevator. When it is desired to ship wheat away from an elevator, advantage is taken of the flowing property of the grain in bulk: the spout is opened and the grain falls through it by gravity and passes into a box-car or the hold of a steamer.

Elevators are of several kinds. There are country elevators along the railways for receiving grain from the 
farmers for storage before it has been inspected, terminal elevators which receive or ship grain and which are located at points declared to be terminal so far as inspection is concerned, hospital elevators which are used for cleaning or specially treating rejected or damaged grain and which are equipped with special machinery for this purpose, and mill elevators which are used or operated as part of a plant engaged in the manufacture of grain products. ${ }^{17}$ In the Western Inspection Division of Canada, for the license year $1916-17$, there were 1,384 railway stations having elevators, the number of elevators was 3,338 , and the total eapacity of all the elevators together was $163,144,000$ bushels. ${ }^{18}$

\section{The Loading Platform}

A country railway station, in addition to its elevators, is provided with a loading platform, a wooden structure on a siding on to which a farmer can drive his team, and from which he can shovel the grain into a car. When the grain has been loaded, the farmer can either sell it on the spot as track grain, or consign it to a commission firm at Winnipeg or Fort William to be sold tor his account, or he may ship it to a terminal elevator to be stored for his account. By using the platform, he can save the elevator charges which amount to about $\$ 17$ per car and avoid negotiations with the elevator companies. On the other hand, he has the trouble of securing the car, of making arrangements to sell the grain, and of loading the grain into the car with his own labor. Some farmers therefore

17 For definitions of elevators vide The Canada Grain Act, 1912, Section 2.

18 Capacity of elevators by Provinces, license year 1916-17, in Supplement to the Cereal Maps of Manitoba, Saskatchewan, and Alberta, Ottawa, 1917, p. 16. 
use the loading platform and others do not. Naturally, the elevator owners look upon loading platforms with disfavor, and railway operators regard them as tending to delay the cars unduly. Their popularity with the farmers, however, is shown by the fact that their number has now been increased to upwards of 1,600 and that about 30 per cent. of the grain shipped from the country points is loaded from them. ${ }^{19}$

\section{The Old Flat Warehouse}

Elevators first came into existence about the year 1880 . Before this time the only receptacles for wheat along the railway line were small flat warehouses built by grain dealers. Farmers brought their wheat to these warehouses in sacks and sold it to the dealers, who shipped it in car lots to Winnipeg for sale. The flat warehouse was divided into two by a passageway running across the middle from the front to the rear, and each end was subdivided into bins. The bottom of the bins was on a level with the ground. The machinery consisted of a scale in the passageway, a trolley for pulling the sacks, and a small four-wheeled grain cart for handling the wheat in bulk. The cart was propelled by hand along a light rail which ran through the passageway to the railway track. When a dealer wished to ship his grain away, he pulled or pushed it to a railway car in his grain cart. The handling of grain is much more efficiently done by an elevator than by the old flat warehouse, and on this account the latter has fallen into disuse. ${ }^{20}$

19 Cf. R. Magill, Grain Inspection in Canada, Department of Trade and Commerce, Ottawa, 1914, pp. 11-14.

20 Ibid., p. 11. 


\section{The Country Elevator}

The country elevators in 1916-17, in the three Prairie Provinces, numbered 3,287 , and the average capacity of each was about 30,000 bushels. Either as single buildings or very often as a row of buildings along the railway track, they form a characteristic feature of western railway stations. They are usually constructed of wood with galvanized iron plates on the outside. This covering serves to keep out water and diminishes the risk of fire.

The farmer hauls his load of wheat from the farm to a country elevator in bulk in an open wagon or, if it is winter time, in an open sleigh. ${ }^{21}$. On arriving at the elevator, he drives his wagon on to the scales which are raised upon a platform about six feet from the level of the ground; and here he obtains the gross weight of his wagon and its load. The elevator operator, with the aid of a crank, then moves the wagon in such a fashion that the front end is raised and the back end is lowered. He then pulls up the door of the grain pit and removes the end-board of the wagon, so that the grain runs out from the back of the wagon into the pit. The empty wagon is then weighed, and its weight when subtracted from the gross weight of the load and wagon previously obtained, gives the weight of the grain deposited in the elevator. If the elevator has a cleaner, the wheat, after passing into the pit, may have its screenings remored, and these may be taken home by the farmer to be used as feed. Finally, the wheat is transferred from the pit to the bins by means of an elevator composed of buckets attached to an endless rubber belt

21 The wheat when being loaded on to a wagon or sleigh is scooped into a grain-tight box holding from 60 to 100 bushels. The invention of the grain-tight box has relieved the farmer of the necessity of hauling his wheat to the elevator in sacks. 


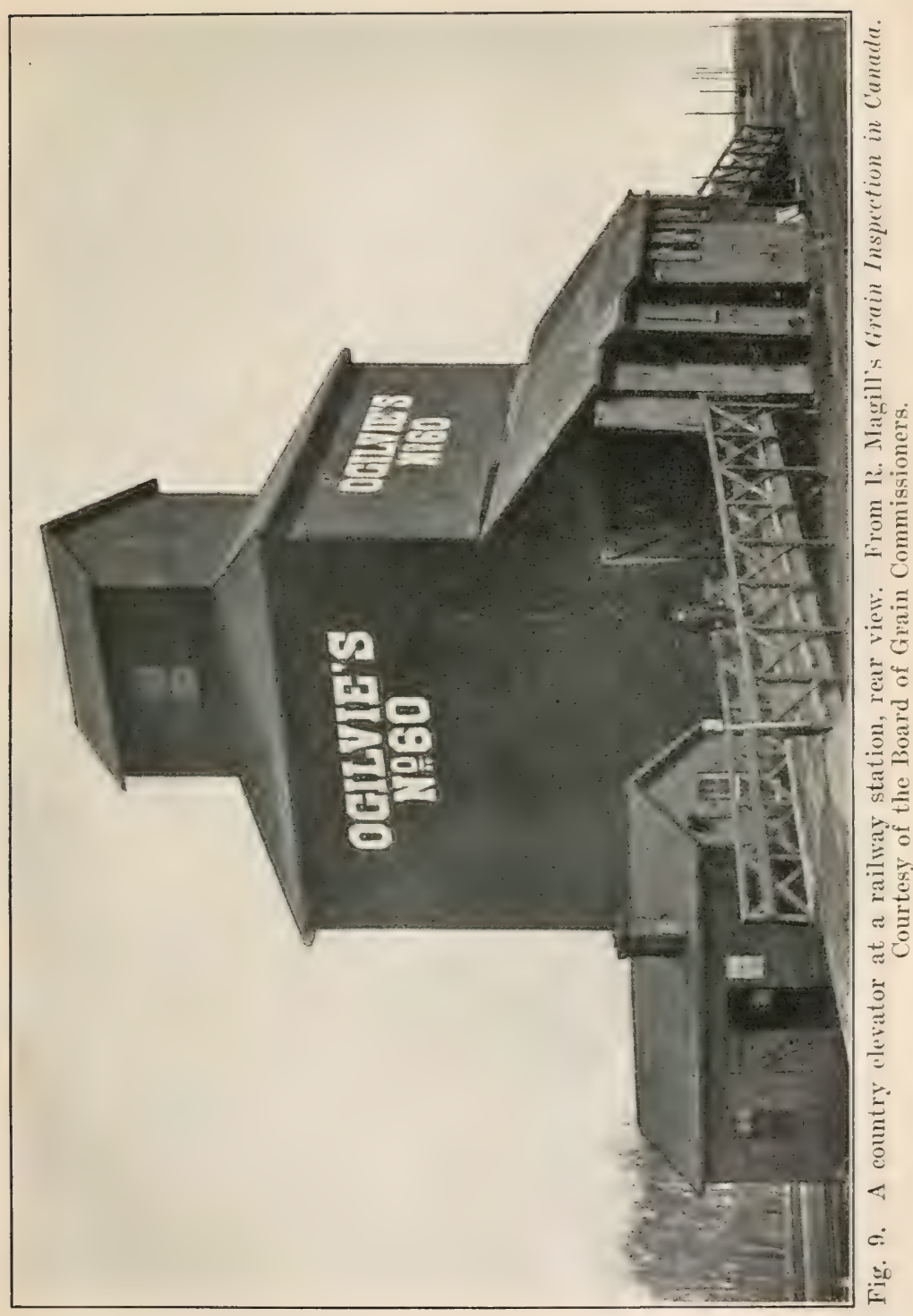




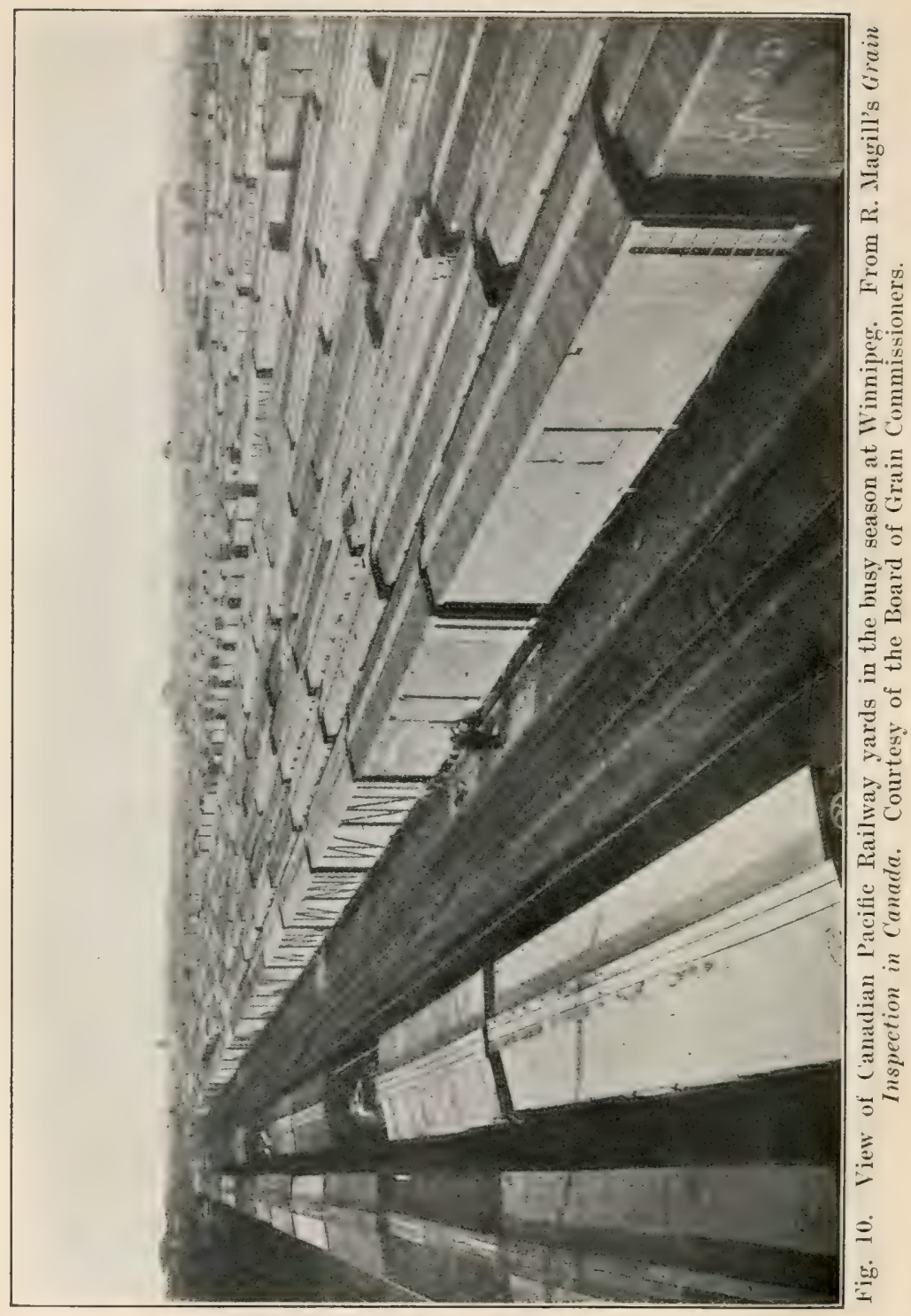


driven by a gasolene engine. Each country elevator contains a number of bins so that the different varieties and grades of grains may retain their identity, and so that a farmer may have his wheat specially binned if he so wishes. One of the bins in the elevator is known as the shipping bin. Its base is about sixteen feet above the railway track and a few feet above the level of the top of a box-car. The storage bins which vary in number from eight to twentytwo, and each of which may hold from 300 to about 4,000 bushels, have their bases about five feet above the level of the ground. When the time comes to ship away the wheat contained in one of the storage bins, the wheat is let out through a hole in the bottom of the bin so that it falls into the wheat pit. From this place it is elevated by the buckets on the revolving rubber belt to the top of the elevator where it is caused to fall into the shipping bin. The bottom of this bin is connected with a spout which can be opened at will to allow the wheat to pass into a box-car.

\section{Box-Cars}

When it is desired to ship out the grain from a country elevator, a box-car is placed alongside of the elevator just by the spout, the two outer side doors are slid open, and a grain door, from about five to six and a half feet high according to the size of the car, is fixed against each opening from within so as to leave a space of about two feet above. The grain, carried by the force of gravity and directed by the spout leading from the shipping bin, is then made to flow laterally into the car over the top of the grain door facing the elevator. The roof of a box-car is always a fixture and grain cannot therefore be put into such a car directly from above. Whilst the grain is flowing into the car - a process which occupies about twenty minutes - 
the spout is directed by the operator to each end of the car in turn, so that the filling is more or less evenly accomplished. If necessary, however, when the car has been filled, the operator climbs into the car over the top of one of the grain doors on his hands and knees and levels the load with a scoop shovel. After the load has been levelled, the outer doors on the sides of the car are slid back into position so as to cover the grain doors and entirely block the two openings. The railway agent then seals the side doors, whereupon the car is ready for transportation to Winnipeg for inspection.

The depth of the wheat in a loaded car is a few inches less than the height of the grain doors and varies from four feet ten inches to six feet four inches, according to the size of the car. Between the wheat and the roof of the car there is always a space left, two feet or more high, in which a man may move when he is obtaining samples of the grain for the government inspector at Winnipeg.

Most of the box-cars now in use for transporting grain are of two sizes only, the smaller cars having a capacity of 60,000 pounds and the larger ones of 80,000 pounds, so that for the former the full load is 1,000 bushels and for the latter about 1,350 bushels. During the last two years, however, the Canadian Pacific Railway Company has been building still larger cars with a capacity of 94,000 pounds, or about 1,650 bushels. The loads in all cases may be exceeded by shippers to the extent of 10 per cent. of the car's capacity without special rates being charged.

Box-cars require to be strongly built, for wheat in bulk, like water, exerts an enormous pressure upon the sides and base of its container. In constructing the grain doors, the original intention was that they should not be nailed or 
fastened in any way when being set in position, so that they might be lifted on the arrival of the car at a terminal elevator and thus allow the grain to flow out beneath them. However, it very frequently happens in practice, and appears to be now the rule, that farmers or elevator operators nail up the grain doors from the inside of the car before the car is filled. The object in view in putting in the nails is to prevent absolutely the grain doors slipping during the switching or shunting of the cars, and thereby to make quite sure that no leakage of grain shall occur whilst the car is in transit. When a car with nailed doors arrives at a terminal elevator at Fort William or Port Arthur, it is necessary, in order to liberate the grain, to smash in the doors with an ax, for the doors cannot be pressed back owing to the weight of the grain or lifted owing to the presence of unseen nails. The destruction of grain doors at the terminal elevators takes place on a great scale and thousands of new doors to replace the old need to be constructed every year.

In the busy season, when grain is flowing freely from the prairie-land to Winnipeg on its way to the lake front, grain trains are made up at the divisional railway points; and night and day such trains, often composed of from forty to forty-five heavily-laden box-cars, form an east-bound procession, one train following another unceasingly. Thus the transportation of the wheat crop makes very heary demands upon the railways every year. To give some idea of what these demands may be, it is only necessary to mention that following the great crop of 1915, one thousand cars of wheat arrived in Winnipeg each working day throughout a whole year, and that the wheat inspected by the Western Grain Inspection Division amounted to $338,425,200$ bushels. 


\section{Terminal Elevators}

Relatively to the country elevators, the terminal elevators where inspected wheat is stored ready for shipment, are few ; but they make up for their small number by their immense size. Upon the immigrant, passing west for the first time and on the look-out for wheat-fields, the imposing bulk and curious form of the terminal elevators at Port Arthur and Fort William make a never-to-be-forgotten impression. Thirteen such elevators have a combined capacity of $41,750,000$ bushels or, on the average, of 3,000 ,000 bushels each. Terminal elevators are usually constructed of concrete, a building material which, although not beautiful to look at, is yet well suited to its purpose; for it gives to the elevators great strength, so that they may resist the pressure of the grain in the bins, and, at the same time, renders them non-inflammable with a consequent saving in insurance against fire.

In the mind of the immigrant, when first he beholds one of the huge terminal elevators, some very curious questions are apt to arise, for while he has heard of the vast crops of wheat which are produced annually in western Canada, he, of necessity, is ignorant of the means whereby the grain is handled for export: "I wonder what all those great big pillars are for? They seem to be quite solid; but I never before saw a building with such thick pillars as those. They don't seem to be supporting much above them. Ah! perhaps they are hollow; but why have they not got windows? How do people see when working in them? I suppose they are lit up with electric light. I wonder whether they have spiral staircases? I suppose the bins are on different floors in each column; but how on earth is the wheat put into them and taken out again?" And so forth; but the immigrant does not stand alone, for 
many a man who has been long, resident in western Canada knows as little about the workings of a terminal elevator as he does about the mechanism of his own digestive system. On passing a mighty building, beautifully specialized to handle grain in the most efficient and economical manner, some there are who regard the pile with no more than the mild curiosity with which, to use an expression of Martin Luther, a cow looks at a new gate: the mystery in concrete is tacitly accepted as insoluble; but others with more enquiring minds actively desire to learn how it carries on its functions, and it is for these that the following pages have been written.

A terminal elevator at Fort William or Port Arthur is situated upon the lake front, so that the grain which it contains may be passed directly into the hold of a lake steamer. It is uplly divided into two parts: the morking house and the storge bins. The working house is rectangitar in shape, much higher than it is long or broad, and has numerous windows in its upper half. Here the wheat is received from the box-cars, elevated, weighed, temporarily stored in smaller bins, and cleaned. Here, too, are situated the shipping bins from which the wheat passes into the freight vessels. The storage bins, on the other hand, are great concrete cylinders which stand vertically upright and are connected by concrete where they are in contact. There may be several parallel rows of them. The space between any four adjacent cylinders is not wasted but is used as a smaller bin. Running over the top of each row of bins is a passageway which leads from the upper part of the working house. The grain is conveyed along these passages and is deposited in the bins from above. Each bin can be filled from the bottom to the top, and a single cylinder may hold as much as 30,000 bushels of grain. Under each row of bins there is a tunnel leading to the 
base of the working house. The wheat is let out of a bin through a hole in its base. The capacity of an elevator depends on the size and number of its cylindrical storage bins. The bins are cylindrical because engineers have found that cylindrical bins resist the pressure of the grain within them better, and require less concrete in their frame, than bins of any other form. In order to comprehend more fully the working of a terminal elevator, let us follow a car-load of wheat into the building, observe what is done with it, and watch it being shipped away.

A car of wheat which has been inspected at Winnipeg is brought to the elevator. The seals on its two outer side doors are broken, the grain doors, if nailed up, are smashed with an ax, and a large part of the grain then pours out of the car. A man then enters the car and, by means of a wooden scoop pulled by chains from the working house, quickly evacuates all the wheat which has remained. The emptying of a car occupies about ten minutes. The wheat falls down on each side of the car through a grating into an opening in the ground known as a receiving pit. From the pit the wheat is conveyed on a revolving belt or conveyor which is lower along the center than at the sides, to the base of the working house where it is elevated to the top of the house by means of buckets attached to an endless rubber belt. On arriving at the top of the house, the wheat is weighed in a scale, the whole car-load at one time. It is then stored temporarily in one of the many small bins available in the working house, cleaned if necessary, and treated in any way desired. It is then transferred from floor to floor by spouts until it reaches the top of the storage bins. Here it is carried along on the top of another revolving belt which runs in the passageway over the top of the storage bins; and it is diverted into whichever of the bins 


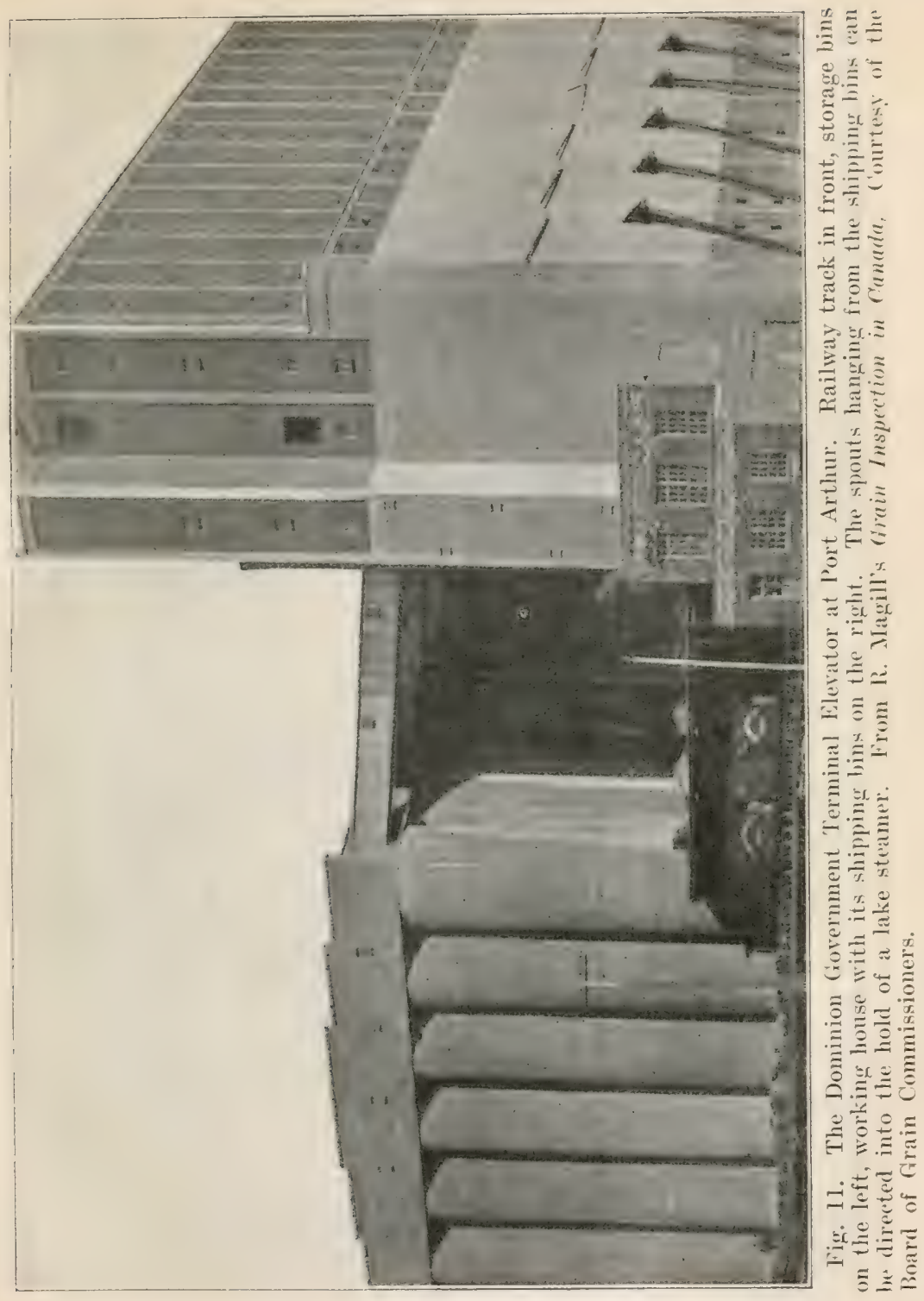




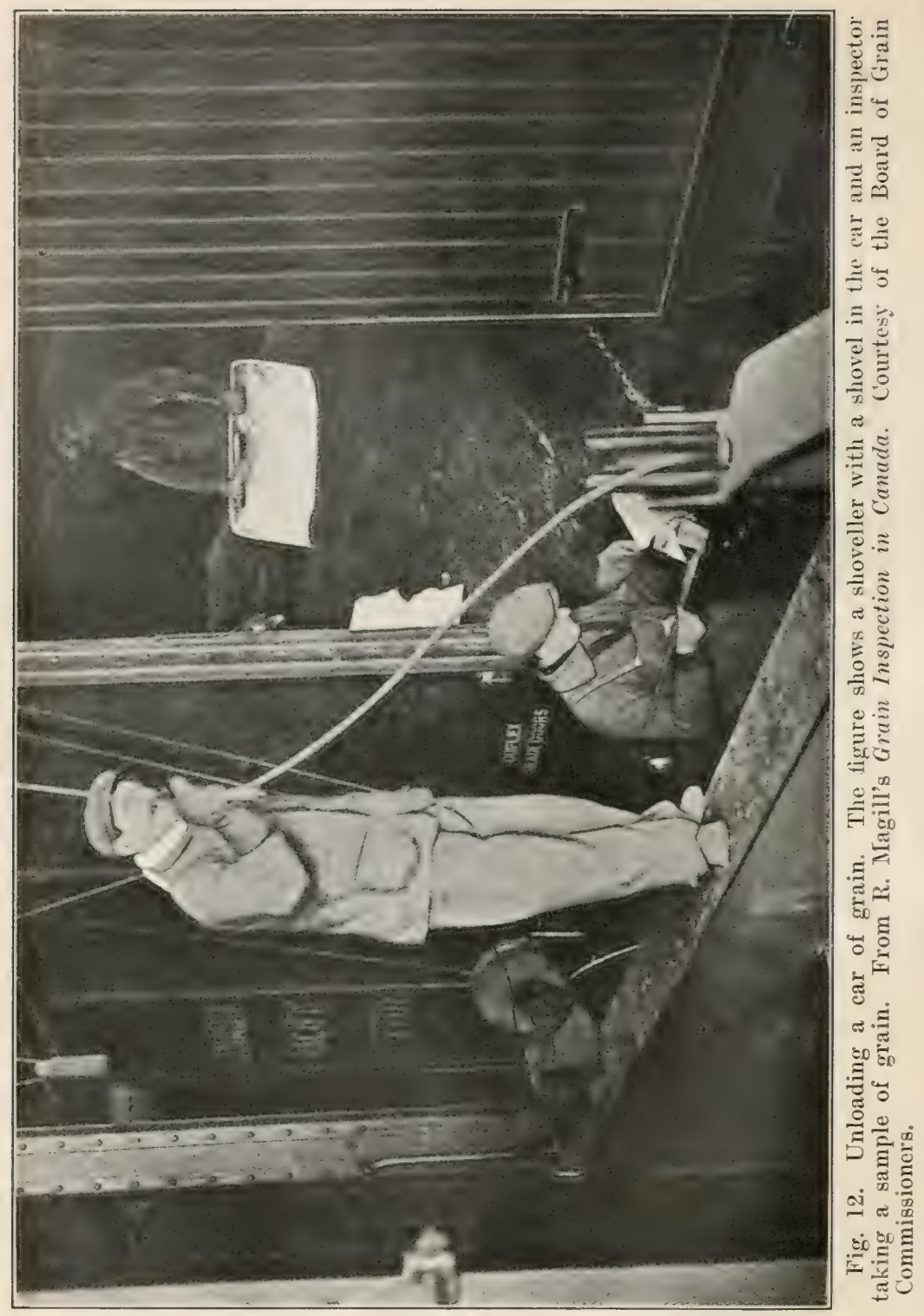


the operator wishes to fill. The different grades of wheat are kept in separate bins. If, therefore, our car-load of wheat has been graded at Winnipeg as No. 1 Northern, it would be deposited in a No. 1 Northern bin, if as No. 2 Northern, then in a No. 2 Northern bin; and so forth. When a car-load of wheat has been put in a bin with other wheat of the same grade, it loses its identity and cannot again be recovered. Wheat in a terminal elevator is therefore stored in bulk according tn grade. This storage in bulk greatly simplifies the work of the elevator and cheapens the cost of handling the grain. The wheat is not only stored in bulk according to grade but is also bought and sold for export in the same manner. We have seen our car-load of wheat pass into the elevator, be weighed, cleaned, and deposited in a storage bin, but here we lose it as such: if it was No. 1 Northern, we simply know that it has been mixed with other wheat in a No. 1 Northern bin. Wheat which has arived at the elevator after the formation of ice has brought navigation to a close, i. e., after the middle of the second week in December, must be kept in storage until the next May when navigation is again resumed or be shipped away on an all-rail route.

When it is desired to ship away, say, 100,000 bushels of No. 1 Northern, the wheat in certain of the No. 1 Northern storage bins is let out through their bases into the tunnels, conveyed by belts running horizontally along the tunnels to the bottom of the working house, elevated by buckets to the top of the working house, and there weighed in the scales. After being weighed, it is sent down the elevator through a system of spouts into one or more of the shipping bins, and from there it is conveyed by spouts on the outside of the elevator into the hold of a vessel or into a railway car. 
The passage of wheat through a terminal elevator is by far the cheapest and most efficient means of taking it from the box cars and getting it on board a lake freight-boat, for loading simply consists of letting the wheat out from a shipping bin through a spout so that it flows by its own weight into the hold. The rapidity with which the cargo boats can be loaded from a terminal elevator is truly astonishing. The average loading run to any boat is about 30,000 bushels an hour; but the record speed for loading at the head of the lakes is 200,000 bushels in one hour and fifty-five minutes.

There are thirteen terminal elevators at Port Arthur and Fort William, one at Vancouver and one at the Hudson Bay. In addition there are four so-called interior terminal elevators. These are situated on the prairie far from any lake or ocean port, at Transcona (near Winnipeg), Calgary, Saskatoon, and Moosejaw. The Transcona elevator was built by the Canadian Pacific Railway to give reserve storage and so relieve the pressure in the elevators at the lake front when such relief is needed. It also serves to supply part of the grain milled between Transcona and the lake front. The terminal elevators at Calgary, Saskatoon, and Moosejaw have been erected by the Government, not to take the place of the lake terminal elevators for grain being shipped east but with a view to supplying the needs of the Hudson Bay and Panama routes when these come to be used. At the same time, they bring the work of inspection somewhat nearer the grain-growing area, give additional storage capacity in times of emergency, and provide useful hospital apparatus for drying wheat damaged by rain or snow before it is sent on a long railway journey to the lake front. ${ }^{22}$

${ }_{22}$ Cf. Robert Magill, loc. cit., pp. 54-56. 


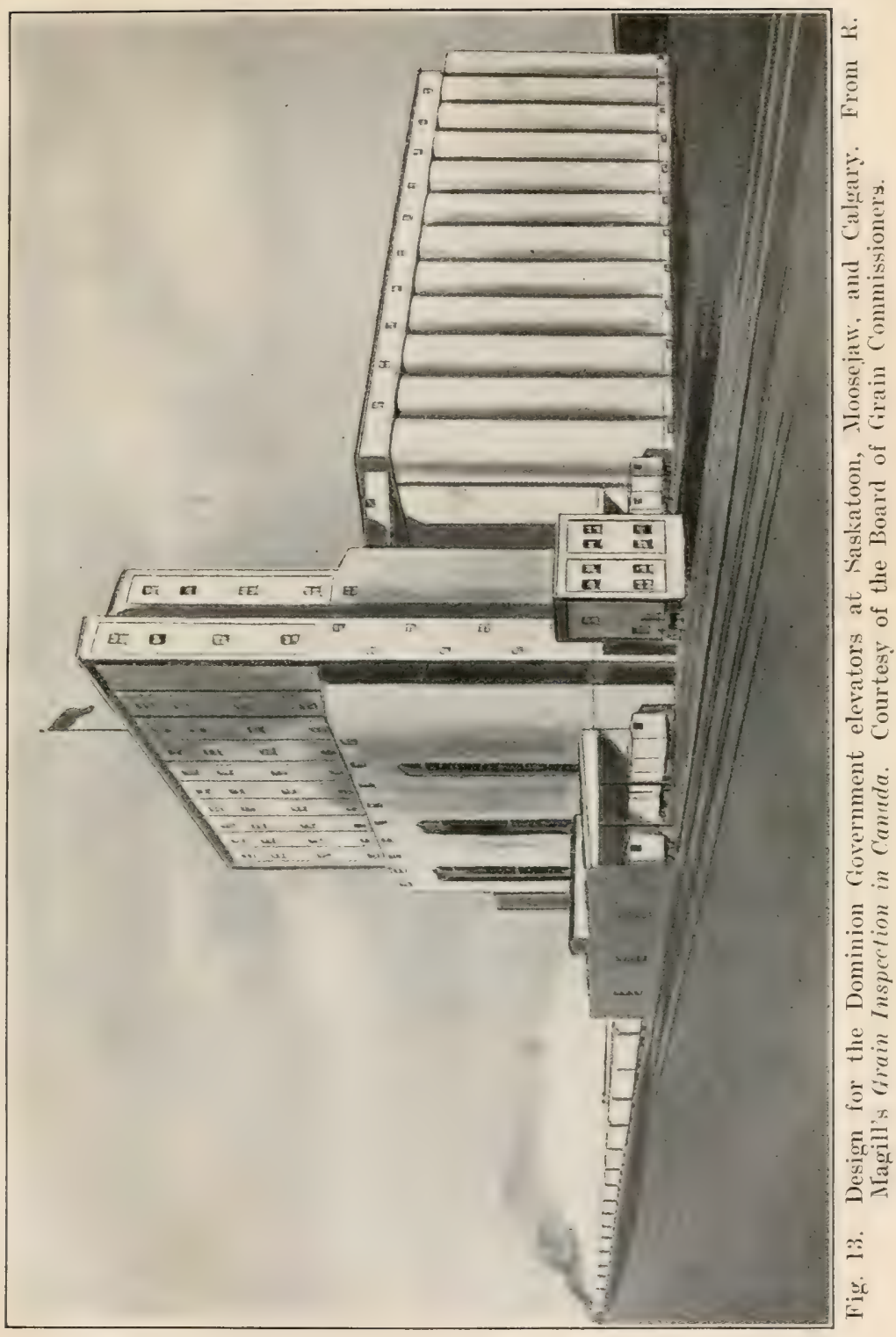





\section{Lake Steamers}

Upon the Great Lakes, there is a large fleet of boats especially constructed to carry commodities in bulk, such as coal, iron ore, and grain. The distance between ports is short and the lake boats, as compared with ocean-going boats, therefore, require but little coal for each journey. In consequence, the amount of space devoted to coal in any ship is small whilst the cargo space is relatively large.

Each vessel is an elongated shell with its machinery at the rear end and the living quarters for the crew placed on deck. The hull is divided by two or three transverse walls from the bottom of the vessel to the deck, so that the number of holds is usually three or four. The deck completely covers these holds, and is provided along the center with a series of hatches which may be opened for the introduction or remoral of the cargo. When a vessel is being loaded with wheat, the grain is spouted into the holds from the shipping bins of an elevator until all the holds are full. Three or four spouts may be discharging wheat at one and the same time. When a boat has been loaded, the hatches are put on so as to close the holds tightly and thus prevent rain or snow or lake water from entering and damaging the cargo. From time to time, great storms rage upon the lakes, and many of these vessels have been wrecked.

"The capacities of these ships," says Piper, "are enormons. An arerage car-load of wheat is a little more than 1,200 bushels. The average train load consists of about forty cars or 48,000 bushels. The larger boats will carry over 300,000 bushels of wheat equivalent to seven train loads, or about three hundred cars. The largest boat now on the lakes will carry nine train loads. The 
best record the Canadian Pacific Railway has yet reached is to haul into Fort William a little more than 1,000 cars of grain a day. Therefore only three or four of these big ships a day are required to take care of all the grain this railway can deliver. These ships are loaded at the rate of from 75,000 to 100,000 bushels per hour and unloaded at the rate of from 20,000 to 40,000 bushels per hour, depending on the machinery equipment of the elevators performing the service." 23

Transportation of freight by water is always cheaper than by rail. It is the recognition of this principle that has led to the development of Fort William and Port Arthur, and which has brought into existence the busy fleet of freighters on the Great Lakes. A single large vessel costs only as much as a few miles of railway track and it moves upon a medium which is forever renewed by Nature herself, so that it never wears out or needs repairing by man. On a water route, there is no investment in a roadbed or in rails, bridges, telegraph lines, or costly terminal yards. The relative cheapness of lake as compared with rail transportation is shown by a calculation of Piper who states that one of the big lake boats " carrying six or seven train loads, will run eleven or twelve miles an hour or about as fast as the arerage speed of freight trains, with a coal and labor cost of about onequarter as much as on the railroad." 24

\section{The Lake Shippers' Clearance Association}

At Fort William and Port Arthur there are now fourteen public terminal elevators all of which deliver grain 23 C. B. Piper, Principles of the Grain Trade, The Empire Elevator Company Limited, Winnipeg, 2nd edition, 1917, pp. 19-20.

24 Ibid., p. 20. 
to boats. Let us suppose that a shipper of a large cargo of wheat has received warehouse receipts showing that the grain to be loaded is distributed in all these elevators. If now it were necessary for him to send his boat first to one elevator to receive a few thousand bushels, and then to another elevator for a few more thousand bushels, and so forth, much valuable time would be consumed and the cost of loading would be considerably increased. Moreover, each small amount loaded would require to be treated as a separate cargo, and the documents and records would be greatly multiplied.

To make it unnecessary for ships to be moved continually from one elevator to another, to save clerical work, and thus to facilitate the dispatch of the grain from the lake front, there has been formed a voluntary organization known as the Lake Shippers' Clearance Association. The shippers who are members of the Association exchange warehouse receipts with one another, and thus each shipper concentrates his cargo which he desires to load, in one or two elevators. If, for instance, a shipper had warehouse receipts for 200,000 bushels of No. 1 Northern of which 50,000 bushels were contained in each of four elevators, he would notify the office of the Association, and the manager would make an arrangement that the shipper should load his boat with 200,000 bushels of No. 1 Northern from one only of the four elevators. The shipper's warehouse receipts for No. 1 Northern in three of the elevators would be exchanged for warehouse receipts for No. 1 Northern belonging to other shippers whose grain was in the particular elevator from which it was arranged that the shipper should draw his whole cargo.

It is evident that the Lake Shippers' Clearance Association carries out its function in such a way as to save 
both time and labor in the transportation of grain. Its work in the end is therefore beneficial to the whole community.

\section{The Canada Grain Act}

As the grain business in western Canada grew in volume and importance, the farmers often complained of the treatment they received from the elevator companies. They accused the elevators of unjust weighing and grading, of paying prices that were too low and exacting charges for handling the grain in the elevators that were too high, of not cleaning the grain, of refusing to give special bins, of pooling profits, of killing competition, and of forming monopolies. They also complained that railway companies discriminated among the applicants in the distribution of cars, and that buyers of grain in various ways took advantage of the grain growers. This dissatisfaction caused Parliament to regulate the business of handling grain by passing a succession of measures. Finally this legislation was codified in the Canada Grain Act of $1912 .{ }^{25}$

The Canada Grain Act creates a Board of Grain Commissioners to administer the Act, defines the statutory grades of wheat, etc., arranges for the establishment of commercial grades, and regulates the grading and weighing of grain. It also contains provisions coneerning the construction of loading platforms, the operation of elevators, the distribution of railway ears, and the trading between the farmer on the one hand and the track buyer and commission merchant on the other. The let requires each person buying grain, and each person or company op${ }^{25} \mathrm{Cf}$. Robert Magill, Grain Inspection in Canada, Department of Trade and Commerce, Ottawa, 1914, p. 14. 
crating a country elevator, to take out an annual licence and to furnish bonds for such an amount as the Board of Grain Commissioners may demand; and it further provides the machinery for the investigation of all complaints made in writing under oath. The whole tendency of the Act is to give the farmer as nearly as can be accomplished an absolute guarantee of fair dealing.

\section{The Sample Market}

Many years ago, both in the United States and Canada, wheat was sold by sample only; but, as the grain trade grew in volume and complexity, this proved unsatisfactory. It was then that the grading system was introduced, first at Minneapolis and Duluth and, subsequently, about 1884, at Winnipeg. The grading system permits of wheat being sold and stored according to grades, the grades being determined by government inspectors.

For the last thirty years, the wheat of western Canada has been sold almost entirely by grade, and sales by sample have been relatively few and unimportant. However, a few years ago, a desire was expressed on the part of a number of farmers that, while the sale of wheat by grade should be continued, facilities should also be given for selling by sample. As a result, by Order-in-Council signed at Ottawa in August, 1917, sample trading was approved. Sample rooms are now provided by the government in the Grain Exchange at Winnipeg, and at Fort William and Port Arthur.

A farmer wishing to sell his grain by sample, marks his shipping bill when shipping his grain, in care of the sample market. On arrival of the consignment at Winnipeg a sample is drawn from the car by the government samplers and is inspected in the usual way. A part of 
it is then taken to the sample market at Winnipeg and another part is expressed to the sample room at Fort William and Port Arthur. The car from which the sample has been taken, is sent from Winnipeg to the head of the lakes, the journey of 420 miles usually occupying several days. If, on arrival at Fort William or Port Arthur, the grain in the meantime has not been sold by sample, it is binned in a terminal elevator in the usual way, in accordance with the grade given to it at Winnipeg. It can then only be sold by grade. To the sample market grain merchants come, examine the samples on exhibit at their leisure, form their own judgment as to values, and, if they are so inclined, make competitive bids for the wheat on sale. On the other hand, samples may be exposed without any bids being made.

The sample market in western Canada has only been organized on a government basis during the last two years, and, up to the present, has been but little used. However, the two years have been war years during which the price of wheat has been fixed. Whether or not, when normal conditions in the grain trade are resumed, selling by sample will prove popular and thereby affect selling by grade in any considerable degree, remains to be revealed by the passing years.

\section{The Grades of Grain}

The grades or classes of wheat are numerous and varied, for this cereal, when marketed by the farmer, is by no means uniform in its admixtures, its condition, or, if clean and in sound condition, in its milling qualities.

The admixtures of wheat may consist of other cereals such as barley and oats, or of flaxseed, or of various weed seeds, such as those of Wild Mustard, Wild Oats, 
Pigweed, and Stinkweed. These admixtures must be removed before the wheat can be milled into flour, and their presence therefore decreases the value of the wheat to the buyer. Whenever a sample of wheat is graded, the admixtures are separated by sieving and weighed. The percentage of admixtures is then determined, and this is called setting the dockage. The amount of the dockage influences the price at which the wheat may be sold, and its accurate determination is therefore a very important part of grain inspection.

The condition of wheat is affected by various causes. Among these are such diseases as smut, wheat scab, and rust. Smut balls are diseased kernels filled with several millions of black spores, the reproductive bodies of the smut fungus. When smutted grain is threshed, many of the smut balls break and seatter their spores over the sound kernels so that the latter become blackened and dirty in appearance. Moreover, smutted grain has a very evil odor, smelling like decaying fish. Smutted wheat, therefore, must be thoroughly scoured before it can be milled. Wheat scab causes wheat kernels to take on a pink appearance. Rusted kernels are usually quite sound although shriveled, but it sometimes happens that they become black-pointed owing to the presence, at the stalk end of the kernel, of a little pustule of black spores of the rust fungus. Wheat may contain too large a percentage of moisture and thus be tough, damp, or wet. It may also be frosted, dirty, musty, heating, or bin-burnt. Frosted grains are known by their wrinkled skin. Heating and burning in the bin so that the grains may even become charred, only take place when the wheat contains too much moisture.

The different varieties of wheat, when free from admixtures and sound, differ from one another in their yield 
of flour both as to quality and quantity. Different lots of a single variety of hard spring wheat, such as Red Fife or Marquis, may vary, with the conditions under which they have been produced, in weight per bushel, in plumpness, in color, and in milling and baking qualities. Hard spring wheat may also contain a smaller or greater number of soft kernels of some other variety, with a proportionate reduction in the grade. The supreme test of wheat is its milling and baking qualities. Judged by this test, however, the crop of even a single variety is never quite uniform, and the difference between two distinct varieties is often very great.

When wheat is classified according to its freedom from admixtures, its soundness, and its milling and baking qualities as indicated by hardness and softuess, the resulting classes are known as grades. Let us now consider the nature of these grades for western wheat.

The statutory grades are the highest grades, are defined in the Grain Act, and do not vary with the crop. There are four of these grades for spring wheat.

No. 1 Manitoba IIard. This wheat must be sound and well cleaned, weighing not less than 60 pounds to the bushel, and must be composed of at least 75 per cent. of Hard Red Fife or Marquis. ${ }^{26}$

No. 1 Manitoba Northern. This wheat must be sound and well cleaned, weighing not less than 60 pounds to the bushel, and must be composed of at least 60 per cent. of Hard Red Fife or Marquis.

26 The definitions here given are taken from the Canada Grain Act of 1912, with the exception of the words or Marquis. The definitions were made when Red Fife was the dominant wheat in the West; but, soon after Marquis began to be largely grown, it became necessary to make provision for the new wheat in the statutory grades. The words or Marquis were therefore added after Red Fife by an order of the Board of Grain Commissioners. 
No. 2 Manitoba Northern. This wheat must be sound and reasonably clean, of good milling qualities and fit for warehousing, weighing not less than 58 pounds to the bushel, and must be composed of at least 45 per cent. of Hard Red Fife or Marquis.

No. 3 Manitoba Northern. Any wheat not good enough to be graded No. 2 Manitoba Northern is graded No. 3 Manitoba Northern at the discretion of the Inspector. ${ }^{27}$

The commercial grades are grades which on account of climatic or other conditions cannot be included in the grades established by the Grain Act. The grain of one year often differs so much from that of another that the lower or commercial grades require to be defined annually. The commercial grades are set by the Western Grain Standards Board and at present are three in number: No. 4 Wheat, No. 5 Wheat, and No. 6 Wheat.

The term no grade is applied to all good grain that has an excessive amount of moisture in that it is tongh, damp, or wet, or grain which is otherwise out of condition and unfit for warehousing.

The term condemned grain is applied to all grain that is in a heating condition or that is badly bin-burnt of whatever grade it might otherwise be.

The term rejected grain is applied to all grain that is unsound, musty, dirty, smutty or sprouted, or that contains a large admixture of other kinds of grain, weeds, or wild oats, or that from any other cause is unfit to be classed under any of the recognized grades.

We thus see that there are seven chief grades of western hard red spring wheat, which, with the word Manitoba left out as is the custom among farmers and grain dealers, are as follows:

27 There is also the grade No. 1 Hord White Fife, but very little of this wheat is grown in the West. 
No. 1 Hard,

No. 1 Northern,

No. 2 Northern,

No. 3 Northern,

No. 4 Wheat,

No. 5 Wheat,

No. 6 Wheat.

statutory grades defined by Parliament.

Each of the three grades of Northern and each of the three commercial grades is subdivided, for the wheat in any of these grades may fall under the general categories of no grade, condemned, or rejected. Thus, for instance, there are at present six divisions of the grade No. 1 Northern as follows:

No. 1 Northern,

No. 1 Northern Tough,

No. 1 Northern Damp,

No. 1 Northern Smutty,

No. 1 Northern - Rejected on account of seeds,

No. 1 Northern - Rejected on account of heat.

We thus obtain, in addition to the one grade for No. 1 Hard, thirty-six grades. But the list of grades is not exhausted with these, for we may have grades consisting of combinations such as:

No. 1 Northern Damp and Smutty,

No. 1 Northern Smutty Rejected on account of seeds; and so forth.

In the autumn of the great rust year, 1916, the Standards Board defined for the crop year 1916-17 an additional grade known as No. 4 Special. This grade included grain which had been badly shriveled by rust. Its minimum weight per measured bushel was only 54 pounds. There is no such grade this year, 1918-19.

There is a grade which is generally recognized by buyers and sellers known as Feed, but it has not been defined 
by the Standards Board. It includes any grain which is not good enough to be put into No. 6 Wheat. Grain known as Feed, as the name suggests, is used for feeding animals.

\section{The Grading of Grain}

An essential element in the grain business of western Canada is the classifying or grading of grain by government inspectors. The wheat is bought, sold, transported, and stored in bulk according to grade. If wheat which comes into the market is graded too low, the farmer suffers an undeserved loss and the miller or grain buyer reaps an undeserved gain. If, on the other hand, the wheat is graded too high, the positions of the farmer and miller are reversed: the farmer gains and the miller loses. The exact price of all grain sold in the Winnipeg Grain Exchange depends on the grade, there being a spread of several cents a bushel between any lower grade and the next higher one. Since the question of grade enters into practically every grain transaction in western Canada, the importance of the accurate determination of grade and the great responsibility resting upon the shoulders of the government inspectors at once become obrious.

The government inspector is in a very delicate position. On the one hand he is liable to receive complaints from farmers for grading wheat too low and in thus being too severe in his judgments, while, on the other hand, he is equally liable to receive complaints from millers for grading wheat too high and in thus being too lenient in his judgments. In addition to this, he may be criticized by the grain merchants either as too severe or as too lenient according as they themselves are sellers or buyers. Thus the inspector is in the position of an arbitrator who daily 
must make decisions of great importance which are binding upon two opposed and powerful interests. For him, therefore, as he values his peace of mind and his security as a government official. there is only one safe path to tread, the path of absolute impartiality. In order to secure this impartiality in the determination of grades, a grading system has been evolved of such a kind that neither the samplers who take the samples of wheat from the boxcars nor the inspectors who grade the samples, have the least idea whence the grain has come, to whom it belongs, or to whom it is consigned. The inspectors must therefore grade the grain simply on its merits in accordance with the standards set up for their guidance.

The task of determining the grade of wheat is by no means an easy one. The inspectors, says Magill, "have to inspect an enormous volume of grain per car unit, and in certain seasons they must work rapidly and continuously during daylight. They must never be bewildered either by the variety or continuity in which nature revels, or by the multiplicity of grades of which the terms are neither very distinet nor unambiguous. They have few mechanical aids. Their senses must always be keen, and their judgment always sound, for one error will be remembered against years of efficient service. Their work is of supreme importance, for their verdict fixes which rate per bushel, out of several quoted on the market, the seller will receive, and the grain is stored, transported, and sold both at home and abroad on their certificate." 28

For the whole of Canada there are two inspection divisions. The Western Inspection Division stretches from the Great Lakes to the Pacific Ocean, and the Eastern Division from the Great Lakes to the Atlantic Ocean.

28 R. Magill, Grain Inspection in Canada, Department of Trade and Commerce, Ottawa, 1914, p. 20. 
The law and practice of grading are the same in both; but, as the varieties of grain grown in the West are different from those grown in the East, the inspectors of the Western Division have nothing to do with the grain grewn in the Eastern Division and the inspectors in the Eastern Division have nothing to do with the grain grown in the Western Division. The Chief Inspector alone has jurisdiction in both divisions.

The Chief Inspector for the whole Dominion is Mr. George Serls, a gentleman who by his integrity has won the confidence of all who are interested in the grain trade. At Winnipeg the Inspector is Mr. J. D. Fraser, ${ }^{29}$ and the number of Deputy Inspectors is thirteen, ten of whom work together at the grading tables at any one time. In addition, the inspection staff includes a considerable number of samplers, yard foremen, clerks, and other assistants. In order to become eligible for the position of inspector or deputy inspector, the candidate must first pass examinations conducted by a Board of Examiners with the aid of the Chief Inspector. The examiners "are experienced grain men, men of integrity, ability, and standing, and men who, though wealthy, are willing to render their service in the interests of the grain industry. The examinations are conducted annually, and they are thoroughly practical tests of the ability to grade. Csually, though not alwars, the candidates are men who have been worting as samplers, track foremen, weighmen, etc., and usually not more than fifty per cent. of the candidates succeed in passing. After passing the examination, the candidate is appointed on the recommendation of the Chief Inspector. Neither in the examination, the recommendation, nor the

29 To Mr. Fraser I am much indebted for showing me through the grading rooms and for giving me a detailed explanation of the grading system. 
appointment have political considerations any place, and this applies throughout the service." 30

If the Government were to attempt to grade wheat at the country railway stations from which the wheat is shipped in the first place, an army of samplers and skilled graders would be required instead of a few, the cost of grading would be greatly increased, and it would be diffcult to give the work of grain inspection the necessary uniformity. It so happens that most of the grain for export passes on its way to the head of the lakes through Winnipeg; and it has therefore been found convenient to concentrate the work of grading in this city. Other inspections, however, are made at Calgary, Moosejaw, and Saskatoon, at Fort William, Port Arthur, and Duluth, the formula for inspection being everywhere the same.

The Government has rented rooms in the building of the Winnipeg Grain Exchange, and in these rooms most of the wheat in western Canada, and all that passes through Winnipeg, is graded. Here, too, the Chief Inspector for the Dominion has his office.

When a grain train from the West arrives at Winnipeg, a sample of wheat is taken from each car, the other details necessary for issuing certificates are collected in the railway yards, and both samples and details are taken to the inspection office in the Grain Exchange. The inspectors determine the grade of wheat in any car from the sample supplied them, and it is therefore very necessary that each sample shall be properly secured. The length of time between harvesting and the close of navigation at the head of the lakes is only about seventy days. It is therefore essential that box-cars containing grain shall be delayed for as short a time as possible at Winnipeg. Moreover, hundreds of cars arrive in Winnipeg during the 30 R. Magill, loc. cit. 
busy season every twenty-four hours. The work of sampling, therefore, has to be carried out at all hours, by night and day, both on Sundays and week days. An accurate and detailed description of the manner in which the samplers and graders carry out their work has been given by Robert Magill, the Secretary of the Grain Exchange, and this will now be quoted.

"The samplers work together in gangs in shifts of eight hours. They work in gangs because team work is more efficient than solitary effort. Usually the gang consists of fourteen men, four of whom are track foremen, eight are samplers, one is a car opener and one a car sealer. ... The track foremen are responsible for the efficiency of the work, each foreman usually looking after two samplers.

"On the arrival of the train, the conductor leares the ear bills in the railway company's yard office. The train clerk of the inspection department makes a list of these bills, showing the car numbers, the name of the shipper, the shipping station, the destination, and the name of the person or company to whom the car is billed. These details are necessary for the issuing of the certificates. He takes this list to the yard office of the inspection department, and hands it to the clerk there. This clerk is also a Government employee, and his work is to prepare the sheets needed in the inspection office. These sheets are two in number, a larger and a smaller. The larger sheet shows all the details mentioned, and the smaller, a carbon copy, only shows the car number and a column for the grade. Both these sheets are sent to the inspection office with the corresponding samples, but the larger sheet with all the details is given to the clerical staff who issue the certificates, while only the smaller sheet is given to the inspectors who grade the grain. In this way all knowledge 
of ownership of the grain is kept from the man who grades it. He does not know whose grain he is grading; his information is limited to the number of the car.

"When the train is ready the work begins immediately. A train consists of about forty-five cars, and the gang should finish with it in less than one hour. The car opener leads off, opening the car doors, and placing an empty sample bag in each car. These bags are well cleaned beforehand, so that no foreign matter shall be mixed in the sample.

"The sampler mounts the ladder, enters the car on the top of the grain, and drives his probe into the grain several times and at several points. He empties the grain each time out of the probe on to a cloth laid on the grain near the car door.

"The space between the grain and the roof is not deep. A line, called the load line, marked on the inside of the car, shows how deep the car should be loaded. It sometimes happens that a car is loaded so full that a fair sample cannot be taken. In such cases the fact of the overloading is put on the ticket by the sign 'I.H.,' which means 'hold for inspection.' Such ears are provisionally inspected at Winnipeg. The car numbers are sent to Fort William with instructions to inspect while being unloaded.

“ Less frequently cars are 'plugged,' loaded, that is to say, with intent to get some low grade grain past the inspectors by concealing it somewhere in the car. The sampler may discover the frand, and if he does not the inspector at the terminal point usually does. Plugging is a losing game for the shipper, for the whole car is graded according to the quality of the worst grain found in it. "If the car is divided by partitions, a sample is taken 


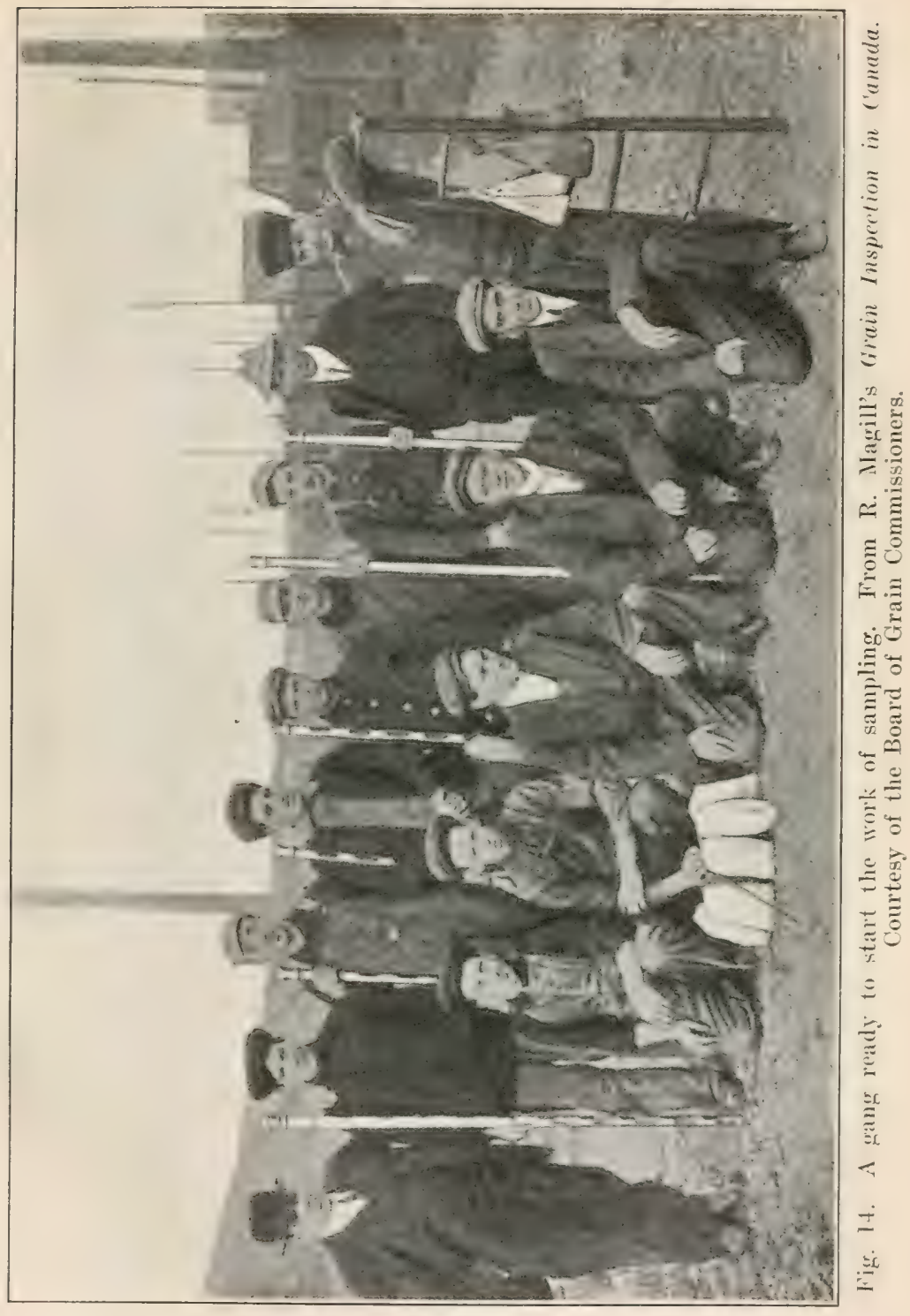




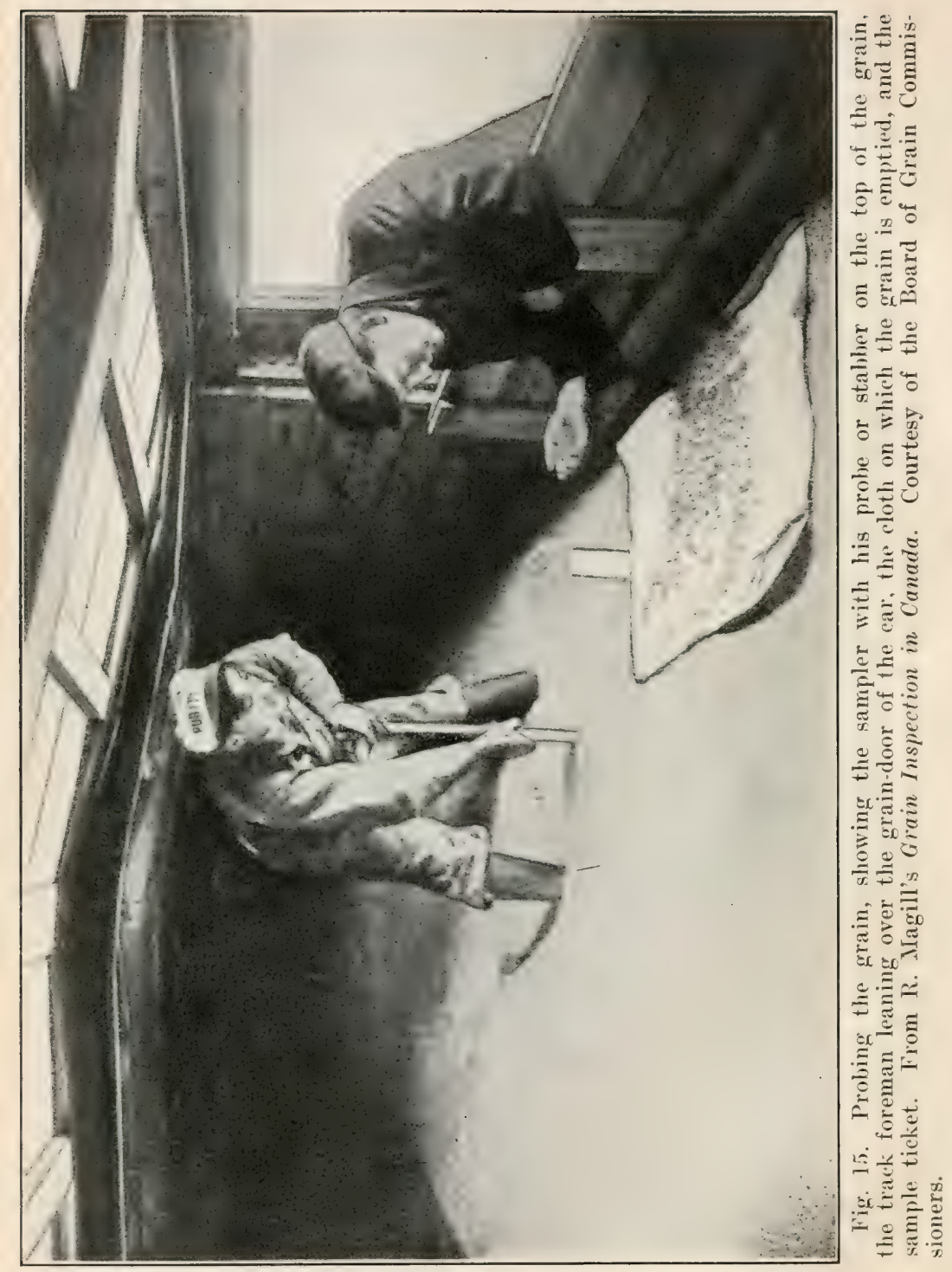


out of each partition, otherwise the unit of quantity for sampling is the car.

"The track foreman mounts the ladder, leans over the car door, watches the probing, mixes up the sample so as to secure an average, puts it into the sample bag, writes the sample ticket, inserts the ticket in the sample bag, and on descending hangs the bign on the car door.

"His name is stamped on the back of the ticket, and on the face he writes the car number, the date, the load line, the initials of the sampler, and any other notations necessary, e.g. leakages, etc. Should any question arise later about the sample, the ticket shows who did the work, the notations made at the time, and the name of the foreman responsible.

"When the sampling is finished, the bags are collected, counted, and taken to the Government office in the yard. The numbers on the sample tickets are checked with those on the track sheet by the car office clerk, and both the samples and the sheets are sent immediately to the inspection office.

"The car sealer follows the samplers, closing and sealing the doors. Every car is sealed at the shipping point by the railway agent. The object of sealing is, of course, to protect the grain on the way. At Winnipeg only one door of the car is opened, and therefore only one seal is broken. The car sealer reseals that door, and the seals are not touched again until the car is placed at the elevator to be unlocked.

"When the samples reach the office they are set out on the tables according to number, those ending in $0-2-$ 4, etc., being put together. Each inspector then takes his sheet, the small one prepared by the car office clerk, and picks out the samples the numbers of which correspond 
with the numbers on his sheet, and he places them in large boxes in rotation as they appear on the sheets.

"The inspection proper then begins. As good light is essential to grading, the inspection begins at 9 A. Mr. and ends at 3 P. м. The north light being the best, each inspector does his grading at a north window. The actual grading can only be done by men legally qualified and appointed either as deputy inspector or inspector. Inspection turns mainly on these points: the quality of the grain, the condition, and the admixtures. The quality depends on soundness, color, weight, and the percentage of hard wheat. The condition depends on moisture content (which in doubtful cases is tested mechanically), heat, etc. The admixtures are tested by a process of sieving and weighing called setting the dockage. In this process either the cleaned grain or the resulting screenings can be weighed. Both methods are permissible and both give accuracy. At Winnipeg the screenings are weighed, while at Fort William the cleaned grain is weighed.

"When the grading is finished, the samples are put into tins, and placed systematically in shelves. They are kept so long as it is considered possible that they may be required, and then they are sold.

"The inspector's sheets are handed over to the clerical staff, and the records made, and the certificates of grade issued."

To the above description of the work of inspection at Winnipeg, a few supplementary details will now be added.

The railway cars are distinguished from one another by numbers painted with large figures on both their sides; but they are not labeled with tickets showing their contents, origin, etc. Cars in which goods have been shipped 
have both doors sealed at the shipping point, so that on the arrival of a train at Winnipeg it is impossible without breaking the seals to look into the cars and see what is inside them. It is therefore sometimes asked: how, in the case of a mixed train in which some of the cars contain grain and other merchandise, does the car opener know which cars to open? The answer lies in the information given by the train conductor. The conductor has a way bill for every car on his train, and the way bills provide him with particulars of the origin of each car, its destination, the shipper, the contents, etc. From these way bills he writes out on a card a train list which shows the number of each car and the nature of the contents. On arrival of the train in the railway yard, he takes his way bills and his train list to the railway yard office. The way bills are then giren to the clerk in the inspection yard office and the train list is put into the hands of the car opener. The car opener then goes out to the train ahead of the samplers and yard foremen, looks at his train list, and opens every car containing wheat, rye, oats, barley and flax, but leaves untouched all those containing merchandise, such as coal, wood, machinery, etc. It is thus the conductor's train list which enables the car opener to do his work with the necessary discrimination.

The seals on railway cars are composed of a narrow band of soft metal with a perforation at one end and a bulb at the other. After the ribbon is put through the hasp of the closed door, the end with the perforation is pushed into an opening in the bulb. Two tiny split rings, like those used for holding keys, hidden in the bulb, then come into play and lock the two ends of the ribbon together. It is impossible to get at these rings without breaking open the seals. The seals are all numbered, and the railway company keeps a list of all those supplied to 
the inspection office. As som as the samplers have finished their work, the car closer pushes the outer door of each car into the closed position and reseals it. Is soon as all the car's have been resealed, he puts on cach end of the train a ticket which states that the work of sampling has been finished. This gires notice to the locomotive engineers that the train may be taken on to Fort William or Port Arthur. All trains containing grain are sampled immediately on their arrival at Winnipes whaterer may br the time of day or night, and the longest grain trains are finished with in ahout an hour. The work of sampling therefore does not delay a train at Wimipeg moluly.

The probe, referred to as being used for obtaining samples from hox-ear's is also known as a sumpler but perhaps more commonly as a stabber. A stalber consists of a double brass tube which is pointed at its base and closed at both ends. Its length is about bi. inches and its diameter 2 inches. Both tubes are perforated on one side by eleren equidistant coincident apertures each of which is about three and a half inches long and one inch wide. Between each two aljacent apertures are unperforated portions of the tubes about two inches long. The inner tube is dirided into eleren chambers by plugs at intervals so that each aperture leads into a single chamber. The inner tube can be revolsed within the outer one by means of a handle at the top of the instrument. By turning the handle, and thus revolving the inner tube, the apertures leading into the inner tube can be closed or opened.

I sampler. when using his stabber in a car of wheat, first eloses its apertures by turning the handle. Ile then pushes his instrument rertically downtrards into the grain. The deeper the stabber is pushed inte the grain, the greater is the resistance which the grain offers. When the print of the stabber is near the ear Honr. considerable 
pressure is required to drive it home, but only a small part of the stabber is left unburied above the grain. At this stage in the proceceling, therefore, the sampler often ceases to use his hands and prepares for a new effort by putting his foot upon the top of the stabber and setting his back against the roof of the car. IIe then exerts the muscles of his body and one leg and at the sume time brings to his ail the whole weight of his body. If a car is very full, the working space between the grain aud the roof of the car may be so small that the sampler may find it necessary first to drive the stabber for some distance into the grain more or less obliquely and then to force it into a vertical position. When the pointed end of the stabber has reached the bottom of the car, the upper end by this time being often almost buried, the sampler turns the handle of the instrument, thereby allowing the grain from eleven different levels to rush into the eleven chambers in the interior of the inner tube. The chambers having been filled, he again turns the handle and thus closes the apertures. $\mathrm{He}$ then pulls out the stabber from the grain in which it has been immersed, holds it lengthwise just above a long piece of cloth by the grain door, and turns its handle so as to open its apertures once more. Immediately the grain falls out of the eleven chambers on to the cloth where it forms a row of eleven corresponding heaps. At least seren stabs are made in each car of wheat and the number is usually nine. The cloth by the grain door thus comes to have deposited on it at least seventy-seven small heaps of grain and usually ninety-nine such heaps. Formerly the stabbers were not plugged and there was but one chamber in each. The wheat was then poured out of a stabber through its open handle, the bottom wheat coming out last. The plugged stabber is an improrement on the unplugged but takes more time to empty. 
As the space between the top of the grain and the roof of a box-car is often very limited, tall men are at a disadvantage in the work of sampling. Taking samples requires considerable physical strength and endurance, and cannot be undertaken by weaklings. The men chosen as samplers, therefore, are of medium height and sturdy build.

The amount of wheat taken out of each car to fill the sample bag is from two and a half to three pounds, and, relatively to a car-load which varies from 60,000 to 100 ,000 pounds, is very small indeed.

Not a day passes without from one to six cars being found unevenly filled or plugged. When a car has been found to be unevenly filled, several separate samples are taken from the load. Thus in one case which came under the observation of the writer, a sample taken from the upper layers of the load graded No. 3 Northern, another sample taken from the bottom layers at one end of the car graded No. 4 Smutty, a third sample taken from the bottom of the other end of the car also graded No. 4 Smutty, while a fourth sample representing an average for the whole car graded No. 4 Smutty. The shipper would have done better with his grain had he put a partition in the car and loaded his No. 3 Northern at one end of the car and his No. 4 Smutty at the other end. The inspectors are aware that uneven filling may be due to accident as well as to design, and they use their judgment in penalizing the shipper accordingly.

If a car is too full, it is impossible to use the stabber properly. Thus, if the space in which the grader must work is only 10 inches high at one end of the car, 30 inches in the middle, and 12 inches at the other end, it is impossible for the sampler to obtain a satisfactory sam- 


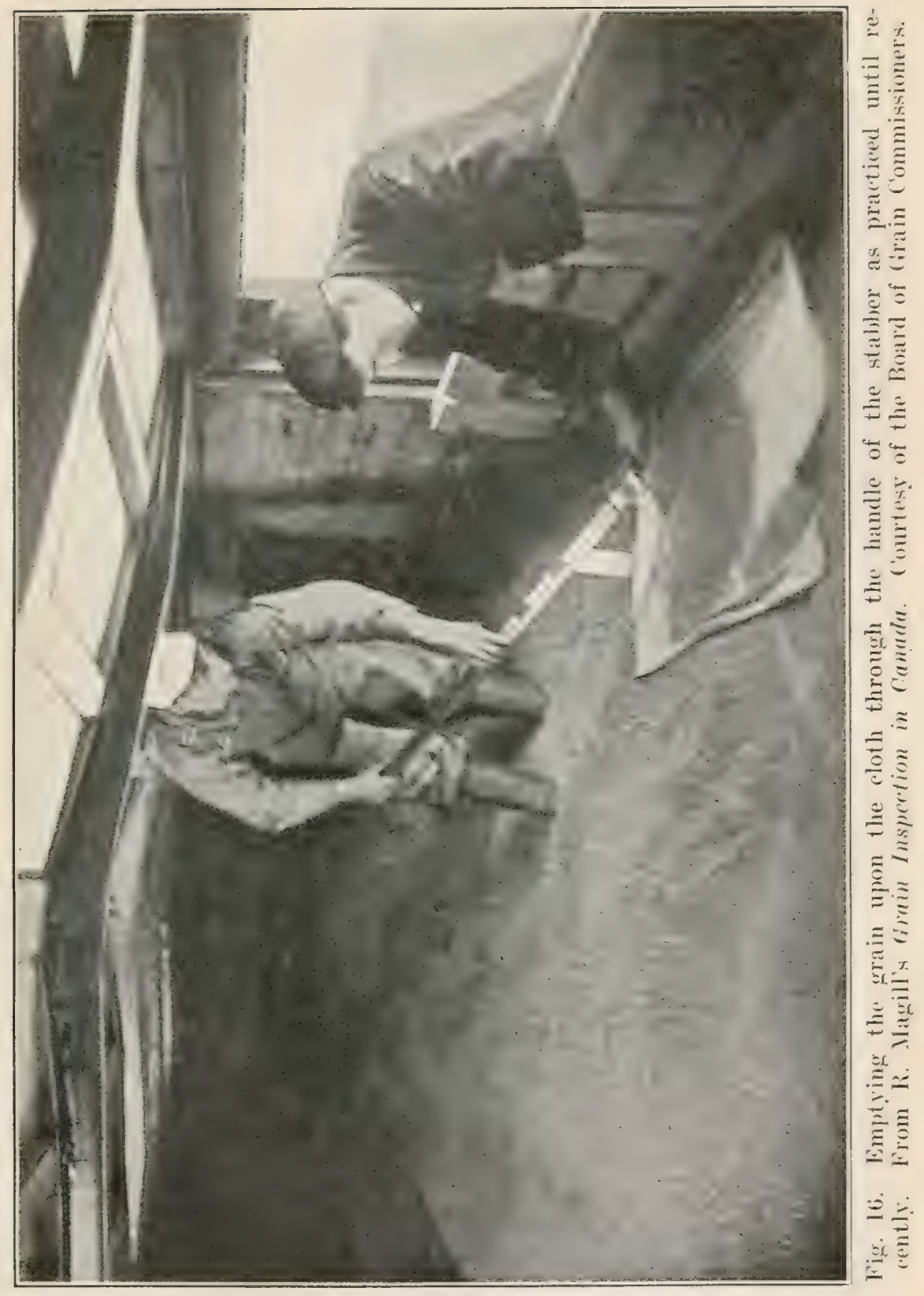




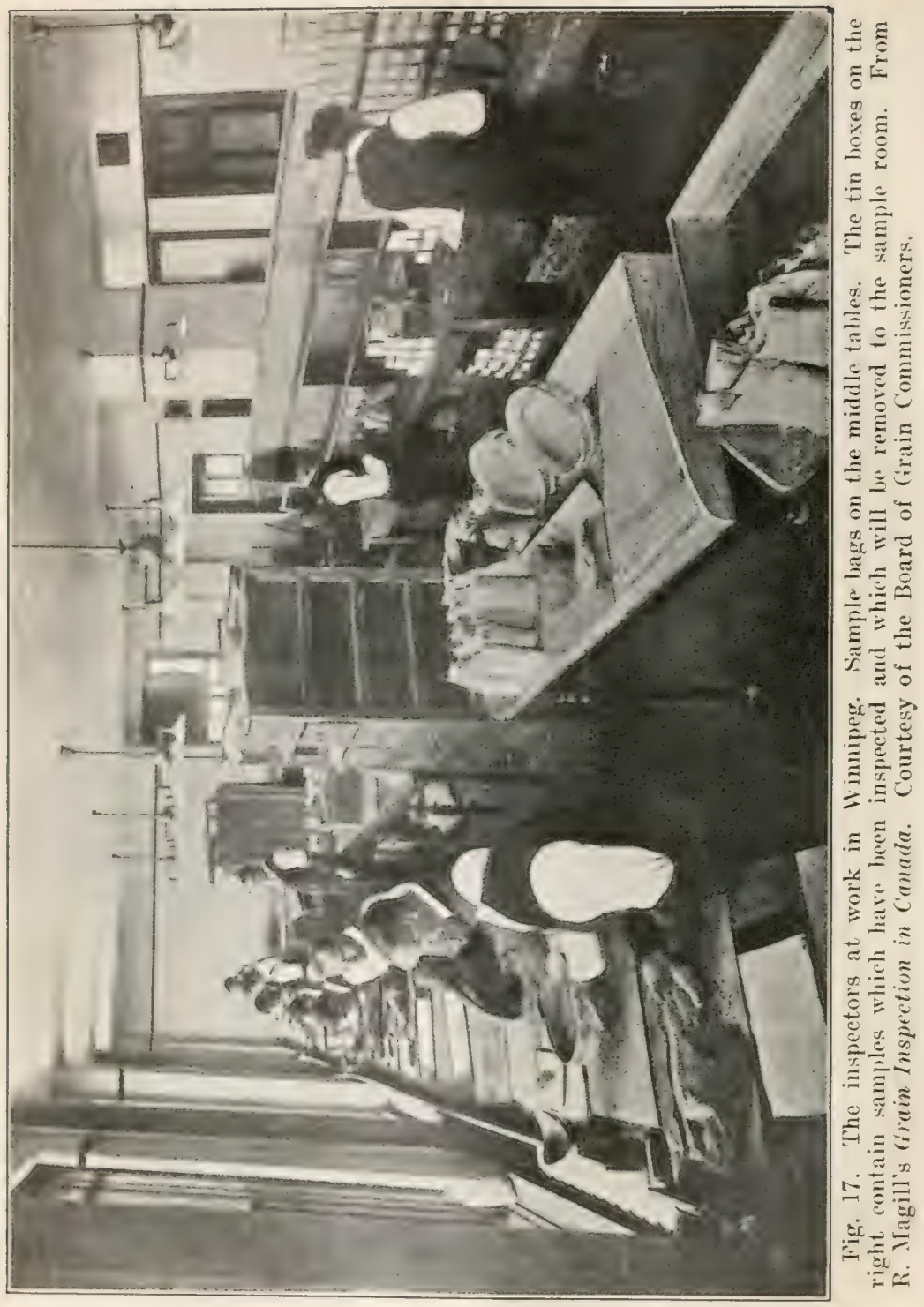


ple. The car is then marked for inspection at Fort William or Port Arthur. The samples are then taken during unloading as the grain is pouring out of the car into the grain pit just prior to its passing into a terminal elevator.

Ten graders usually work side by side at the long window table in the grading room. Standard samples of the six grades, No. 1 to No. 6, are kept in boxes in front of each grader, so that he may refer to them for comparison whenever he so desires. A handful of wheat from the sample of each car inspected is put into a pail by each grader, the grades being kept separate. The pails are emptied monthly. Thus monthly averages can be compared for the information of the inspectors.

The first operation in the work of grading is to determine the weight of the grain per measured bushel. A piece of brown paper about eighteen inches square is spread out on the grading table, and upon it is set an imperial quart measure, made of brass and attached to a beam balance. The sample to be graded is then poured from its bag into the quart measure until the latter overflows. The grain is then stroked off level at the top. The balance is then suspended from the hand and the weight moved along the beam until equilibrium has been established. The number of pounds weight the wheat weighs per bushel is then read off directly from the scale on the beam. As we have seen, No. 1 Hard and No. 1 Northern must weigh not less than 60 pounds to the bushel, and No. 2 Northern not less than 58 pounds to the bushel. Weight per bushel is also taken into account in connection with other grades, and its determination is therefore an important feature of grading. When the weight per bushel has been taken, the wheat in the quart measure is poured out on to the sheet of brown paper. 
Usually the paper is then taken up and the wheat upon it poured back into the sample bag. The weight per bushel is recorded on the ticket in the bag.

When there is the least chance that the amount of dockage may influence the weight per bushel to the extent of affecting the grade, the dockage is removed and the weight of grain per measured bushel again determined.

To estimate the amount of the admixtures of weed sceds and oats, etc., i. e., to set the dockage, the sample is poured out on to the sheet of brown paper and then thoroughly mixed by hand. Then one pound of the wheat is put into a hopper and weighed out on a balance. The inspector then takes a standard sieve with ten meshes to the inch each way and pours the pound of wheat into it. The sieve is then shaken until the weed sceds have come through, leaving the wheat behind. If buckwheat is present, this is left behind with the wheat, and the wheat and buckwheat are then sieved again with another sieve of special construction having triangular holes. Through these holes the buckwheat passes, leaving the wheat behind. Then, if oats or wild oats are present with the wheat, the oats and wheat are shaken in another sieve with larger rounded holes. Throngh these holes the wheat passes, leaving the oats and wild oats behind. The dockage is then collected and weighed on the same balance that was used for weighing out the original pound of wheat. As soon as equilibrium has been established, the percentage of dockage for the wheat is read off directly from the scale on the beam bearing the weight and at once recorded on the sample ticket. By weighing the dockage which is relatively of small mass, there is less chance of making a spill than when weighing the cleaned grain. If any of the dockage should be spilled before weighing, the spill will operate in faror of the farmer. 


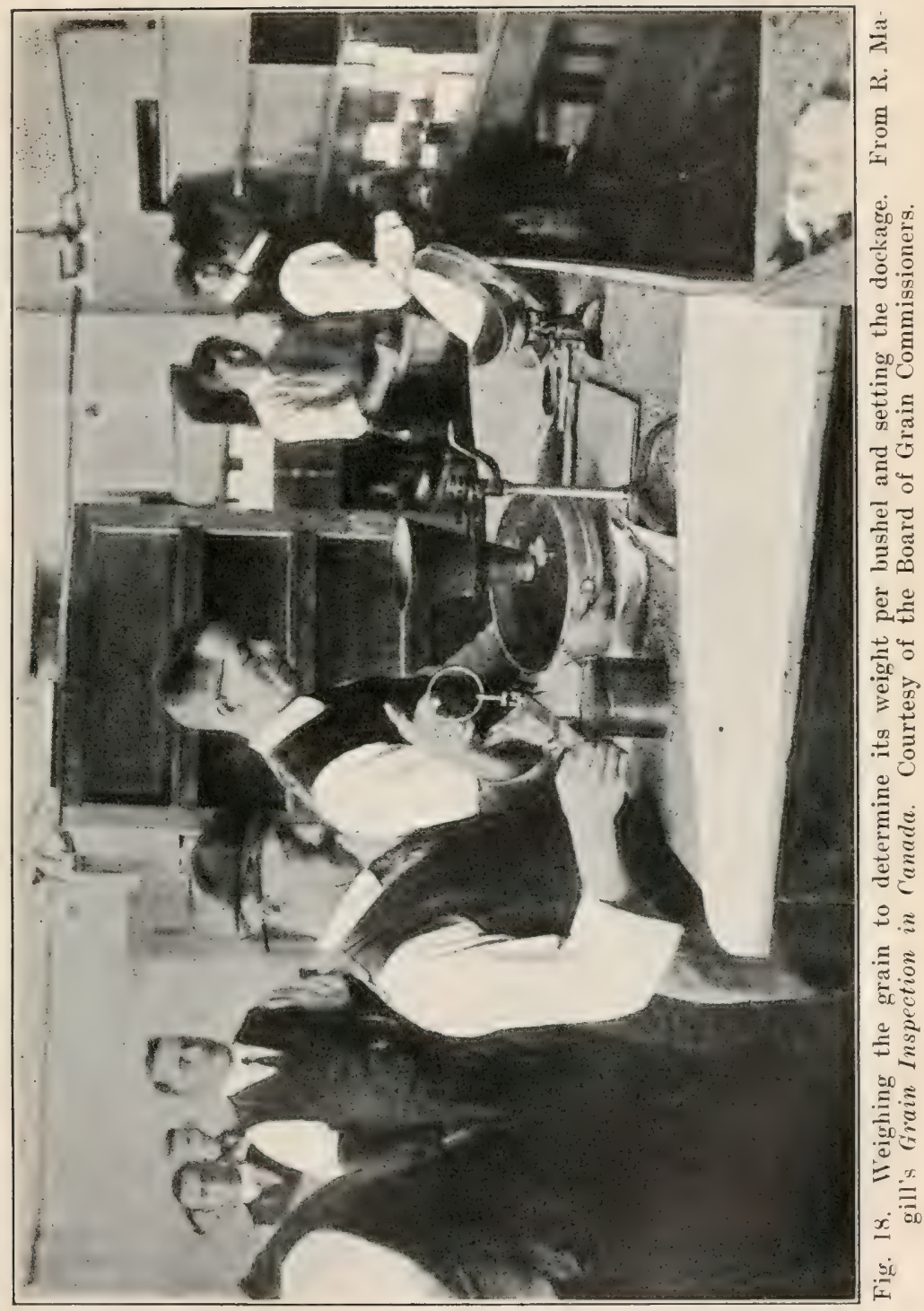



In testing for the amount of moisture, the wheat is spread out on the brown paper sheet and felt with the fingers. Dry wheat slips through the fingers more easily than wheat containing a considerable proportion of moisture. Tough or damp wheat gives a clammy impression. Most samples of wheat can be classified at once as dry, tough, or damp by the feel. All doubtful samples are tested for amount of moisture in a Brown-Duvel moisture tester. The test is carried out as follows: One hundred grams of wheat are weighed out very carefully and put into a glass retort with 150 cubic centimeters of engine oil. Then a thermometer, passing through the rubber cork of the flask, is inserted into the mixture of wheat and oil. The switch of an electric heater is then turned on, and the temperature of the contents of the flask is raised to $180^{\circ} \mathrm{C}$. The oil and wheat thus come to be raised to a temperature far above the boiling point of water. Is a consequence, the moisture in the kernels is turned into steam. The steam is conducted through a glass tube which passes into a tank of running water. Here the steam is all condensed and the water arising from it runs into a glass tube graduated according to percentages of moisture in 100 grams of wheat. This crop year, 1918-19, wheat having up to 14 per cent. of moisture is passed as dry grain, wheat having over 14 per cent. moisture and up to 17 per cent. is graded as tough, and wheat with more than 17 per cent. moisture is graded as damp. About ninety tests with the Brown-Duvel apparatus for determining moisture are made every day.

The grader, as we have seen, has mechanical aids at his disposal in the weighing machine, the sieve, and the moisture tester; but for the rest of his work he must use his sense of sight, his sense of touch, and his sense of smell. The farmer tends to see the good liernels in the grain 
which he hauls to the country elevator, but it is the business of the government grader to find the poor kernels in each sample and to estimate their number and nature relatively to the good ones. He has to take note of the proportion of shriveled grains, immature grains, smutted grains, pink grains, soft grains, frosted grains, etc., and in forming his judgment must rely on his own keen senses, his expert knowledge, and his experience.

The charge for inspecting a car of wheat is 60 cents, and this, added to 40 cents for weighing, makes a total inspection and weighing charge to the farmer of one dollar per car.

An inspector, after grading a sample, at once writes down his report on his sheet containing car numbers. This sheet eventually goes to the clerical staff who prepare the certificates of grade.

The wheat composing any sample, after being graded, is put into a tin box which is nine inches long, three inches high, and three inches wide. The box is filled, and, when full, holds about two pounds of grain. Each box is labeled outside with the car number, date, etc., and contains within the original sample ticket which now sets forth the car number, the initials of the sampler, the name of the yard foreman who put the sample in the bag, the depth of the wheat in the car, the grade, the amount of dockage, the grader's name, and the dates of taking the sample and grading. The boxes are carefully filed on shelves in the sample room. The sample room, which adjoins the grading room, at any one time contains about 60,000 tin boxes which are kept filled for as long as they are likely to be needed for reference and are then emptied. An official goes through the sample room and empties a certain number of boxes each day and thus makes room for new ones coming daily from the grading 
room. The contents of the wheat boxes are emptied into a sack so that they are all mixed together. This mixed grain, made up of all grades, is then sold by the Government and the proceeds go toward paving the expenses of the Grain Inspection Department. The grade at which the mixed grain is usually sold is No. 3 Northern. Any one may bid for the grain who wishes. A considerable proportion of it is disposed of to a local milling company who fetch so much away each day.

The large amount of work which falls to the Western Grain Inspection Division is shown by the following statistics. $^{31}$

Number of Cars Inspected in the Crop Year 1916-17

\begin{tabular}{l|r|r|r|r|r|r|r}
\hline $\begin{array}{c}\text { Point of } \\
\text { Inspection }\end{array}$ & Wheat & Oats & $\begin{array}{r}\text { Bar- } \\
\text { ley }\end{array}$ & Flax & Rye & $\begin{array}{c}\text { Sereen } \\
\text { ings }\end{array}$ & Totals \\
\hline Winnipeg .. & 147,773 & 42,840 & 7,204 & 5,822 & 52 & 433 & 204,124 \\
Saskatoon ... & 5,377 & 1,331 & 42 & 234 & $\ldots$ & $\ldots$ & 6,984 \\
Calgary .... & 3,939 & 3,175 & 757 & 48 & 71 & 9 & 7,999 \\
Moosejaw ... & 4,634 & 822 & 21 & 121 & 5 & 10 & 5,613 \\
Medicine Hat & 2,710 & 25 & 4 & 104 & $\ldots$ & $\ldots$ & 2,843 \\
Duluth .... & 2,585 & 612 & 147 & 113 & 62 & $\ldots$ & 3,519 \\
\hline Totals .... & 167,018 & 48,805 & 8,175 & 6,442 & 190 & 452 & 231,082 \\
\hline
\end{tabular}

From the above Table the dominating position of Winnipeg as a center of grain inspection may be readily perceived. For the crop year 1916-17, 147,773 cars of wheat out of a total of 167,018 were inspected in that city. During the busy season as many as 2,000 cars are often graded by the Winnipeg inspectors every day.

31 The statistics are taken from the Ninth Annual Report (new series) of the Winnipeg Grain Exchange, Winnipeg, Sept., 1917, pp. 85,87 . 
Number of Cars of Wheat Inspected in the Western Grain Inspection Division During the Crop Years Stated

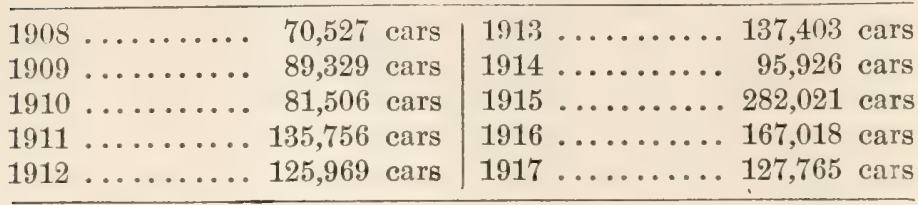

To show how the grades are distributed, the statistics for the grades for the crop years 1914, 1915, and 1916 may be quoted. In 1915, the wheat crop was the largest ever obtained in the West, while in 1916 the crop suffered severely from the rust disease.

Number of Cars of Different Grades in the Crop Years Stated

\begin{tabular}{|c|c|c|c|}
\hline Wheat & 1914 & 1915 & 1916 \\
\hline Hard No. 1........... & 21 & 2,126 & 79 \\
\hline Northern No. 1 ......... & 16,152 & 138,117 & 18,261 \\
\hline Northern No. $2 \ldots . . .$. . & 32,735 & 49,110 & 32,262 \\
\hline Northern No. 3 ......... & 23,057 & 36,497 & 30,207 \\
\hline White Fife ............ & 1 & 1 & $\ldots \ldots$ \\
\hline No Grade and Feed ....... & 3,833 & 21,962 & 40,885 \\
\hline Rejected .......... & 3,848 & 9,336 & 3,171 \\
\hline Commercial Grades . & 15,990 & 23,954 & 41,828 \\
\hline Winter Wheat ....... & 216 & 742 & 166 \\
\hline Condemned $\ldots \ldots \ldots \ldots$ & 60 & 82 & 93 \\
\hline Others $\ldots \ldots \ldots \ldots$ & 13 & 94 & 66 \\
\hline Total cars . & 95,926 & 282,021 & 167,018 \\
\hline
\end{tabular}

The importance of accurately determining the grades of car-loads of wheat is shown by the following Table which gives the price of wheat in cents per bushel for the chief grades for the crop year 1918-19. These prices were fixed by the Board of Grain Supervisors as a war measure; but corresponding differences in prices affect 
the grades in normal vears, when there is open competition in buying and selling. The blanks in the table indicate prices that were not fixed.

Fixed Prices in Cents per Bushel, for the Crop Year 1918-19, for Wheat in Store at Fort William or Port Arthur

\begin{tabular}{l|c|c|c|c}
\hline & $\begin{array}{c}\text { Straight } \\
\text { grades }\end{array}$ & Tough & $\begin{array}{c}\text { Rejected } \\
\text { on account } \\
\text { of seeds }\end{array}$ & Smutty \\
\hline No. 1 Northern.... & $2241 / 2$ & $2181 / 2$ & $2141 / 2$ & $2151 / 2$ \\
No. 2 Northern.... & $221 \frac{1}{2}$ & $2151 / 2$ & $2111 / 2$ & $2121 / 2$ \\
No. 3 Northern.... & $2171 / 2$ & $2091 / 2$ & $2061 / 2$ & $2081 / 2$ \\
No. 4 Wheat...... & $2111 / 2$ & $\ldots$. & $\ldots$. & $\ldots$ \\
No. 5 Wheat....... & $1991 / 2$ & $\ldots$. & $\ldots$ & $\ldots$ \\
No. 6 Wheat....... & $1901 / 2$ & $\ldots$. & $\ldots$ & $\ldots$ \\
\hline
\end{tabular}

The difference in price between two grades is known as the spread. From the above Table, it is clear that the spread between the different grarles is often considerable. Thus, in respect to the straight grades, the spread is as follows: between No. 1 Northern and No. 2 Northern, 3 cents per bushel; between No. 3 Northern and No. 2 Northern, 4 cents; between No. 4 Wheat and No. 3 Northern, 6 cents; between To. 5 Wheat and No. 4 Wheat, 12 cents; and between No. 6 Theat and No. 5, 9 cents per bushel. The spread between No. 6 Wheat and No. 1 Northern in the straight grades amounts to 34 cents per bushel. The grades thus very materially affect the price which the farmer gets for his wheat, and it is not therefore surprising that grades and grading are subjects in which he is keenly interested.

\section{Inspection at Terminal Elevators}

One of the chief objects in grading grain is to classify the grain for bulk storage in the terminal elevators. The 
individual car-load is merged, as we have seen, in a bin containing grain of the same grade; and thus the cost of storage is lessened. It is highly important that the car-loads should be deposited in their right bins according to grade.

The Winnipeg inspection governs the storage in the terminal elevators except in the following cases: (1) cars which were too full for proper sampling at Winnipeg, (2) cars that have been "plugged," (3) cars that have gone out of condition, (4) cars on which reinspection has been asked, and (5) cars upon which an appeal to the Survey Board has been demanded. All these cars are sampled and inspected whilst being unloaded.

Every evening the Winnipeg inspection office dispatches to Fort William by express train a sheet showing the car numbers of inspected cars, the grade, the dockage, the inspector's notations, the shipping point, the destination, the party to whom the car is billed, and the number of the inspector's certificate. As trains are broken up at Winnipeg, or between Winnipeg and Fort William, a new train sheet is made out at Fort William. This sheet is made from the car bills and from the Winnipeg sheet, and it shows the Winnipeg sheet number, the grade and notations, the elevator to which the car is sent, and the shipping point. ${ }^{32}$

At Fort William a grade ticket is then made out for each car and nailed to the car. As the grain is pouring out from the car during unloading, an inspector takes samples at intervals with a ladle, mixes up the grain thus taken, and then decides whether or not the grade is the same as that on the grade ticket. Usually the grades, when thus checked over, are confirmed. Very exceptionally they are found to be different. In case of any altera32 Vide R. Magill, loc. cit., p. 35. 


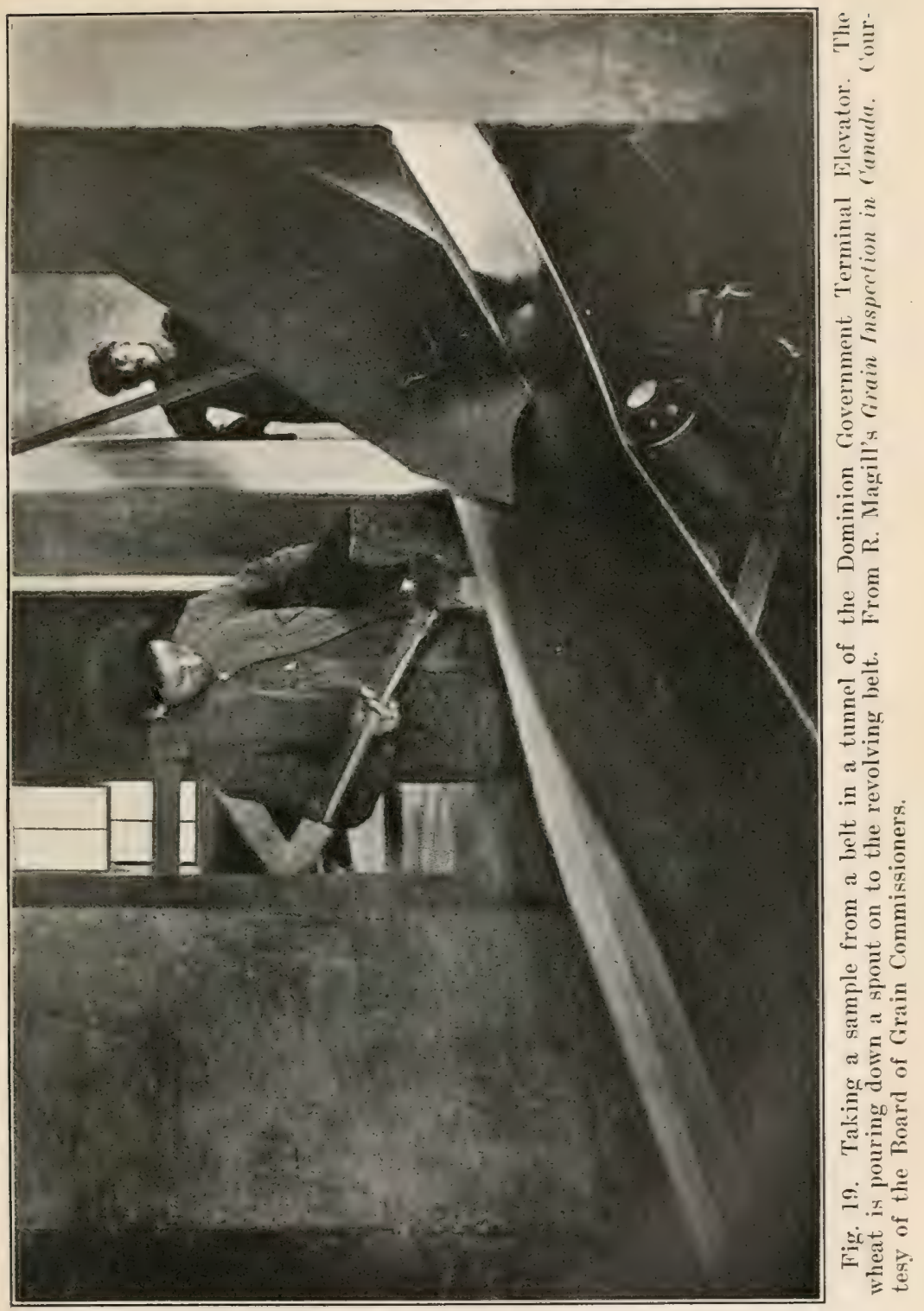






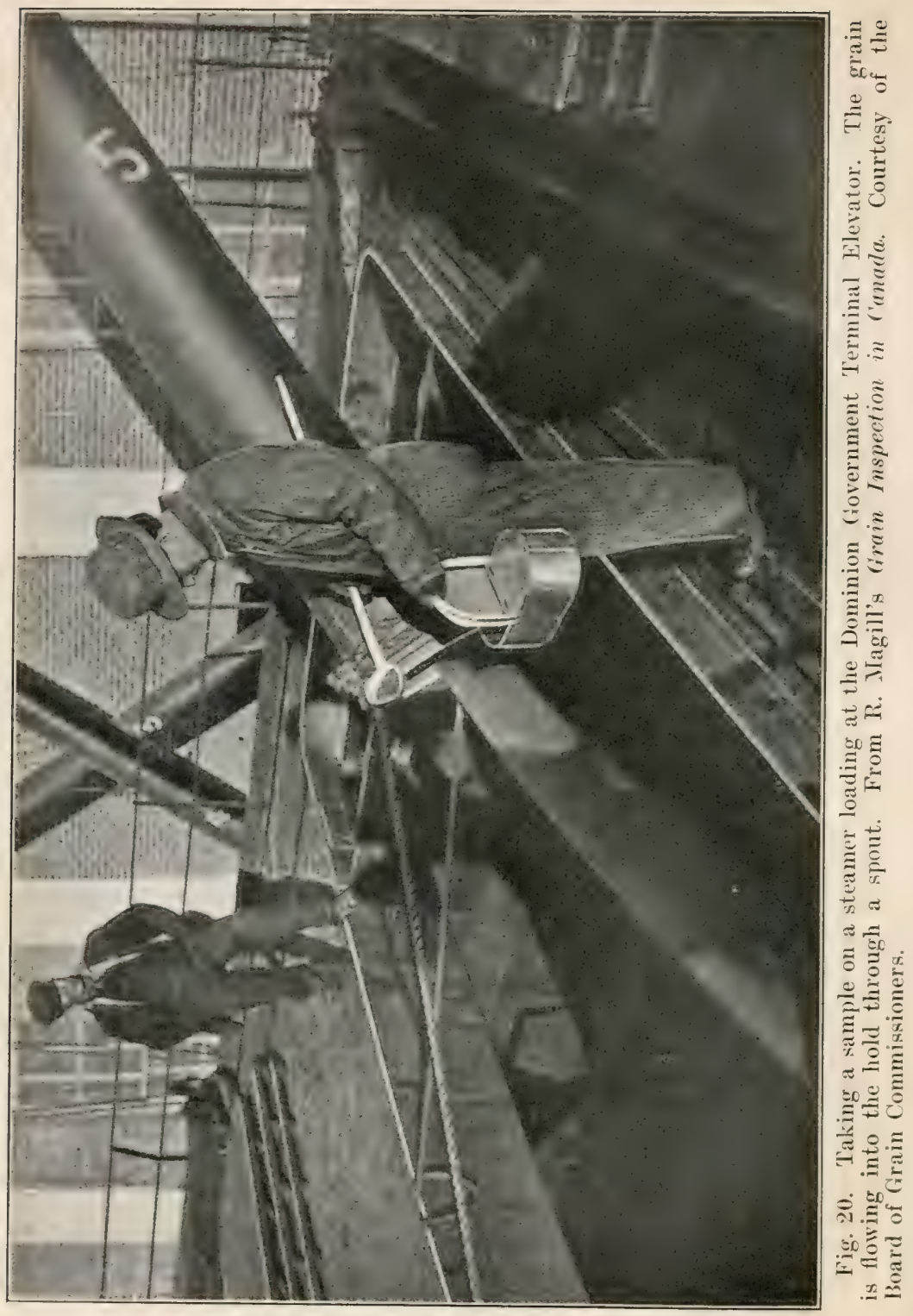


tion in grade, the Winnipeg Inspection office is notified by wire, and the Winnipeg grade after investigation may be altered.

A report of all cars unloaded at each terminal elevator is made daily. The report shows the carrying company, the car number, the date, the Winnipeg sheet number, the Fort William sheet number, the grade, the dockage, the seal record, the condition of the car (damages, leaks, bulkheads, etc.), the load line, the inspection notations as to grading, cleaning, etc., and the weighman's notation. One copy of the report is supplied to the elevator, one is sent to the Chief Inspector at Winnipeg, and one is retained in the inspection office at Fort William. The grain is taken into storage in the elevator just after unloading and is binned with other grain of the same grade. It is thus seen that the government keeps a most careful record of all grain entering each terminal elevator. ${ }^{33}$

Wheat is not only graded into a terminal elevator but it is also graded out again. "Grading the grain as it is being loaded out of the elevators into the lake steamers," says Magill, "presents some difficulties not experienced in Winnipeg. It is easier to secure a fair arerage sample of the grain in a standing car, than to secure one out of a mass of grain rushing in several streams from a huge elevator into a steamer. Further, the car sample in Winnipeg is graded in the central office and not in the railway yard, but grain being loaded into a steamer must be graded there and then. To sample the grain, send the sample to a central office and grade it there, might mean that the wrong grain would be loaded into the vessel, and the steamer started off with grain different from that called for by the shipper. To unload grain out of a vessel at Fort William would be difficult, as there are no marine legs,

33 Vide R. Magill, loc. cit., p. 39. 
and to delay the steamer would add to the cost. The grain must be graded as it runs from bin to boat.

"An inspector with assistants is placed in charge of each elevator, and he is held responsible for the grading out. The grain is sampled at three places: in the tunnels as the grain runs from the storage bins to the working house, on the floor of the working house, and on the steamer as it pours from the shipping bin into the hold.

"If any grain is seen at any of these places which is not up to the required grade, the stream is stopped instantly. While the grade is given by the inspector in charge of the elevator, all the three samples are sent to the inspection office at Fort William and examined there. In this way the grading by the inspector in the elevator is checked by the grading of the inspector who has charge of all the inspection at the terminal points, Mr. Symes. A sample of every cargo with the Fort William inspection is also sent to the Chief Inspector at Winnipeg." 34

\section{Reinspection}

The certificates of grade for each car-load are sent out to those who should receive them as soon as they have been written, and the corresponding samples are filed in the sample room. The owners of the grain, or their representatives, then have the privilege of examining the samples in the sample room and thus of judging whether in their opinion the grades are satisfactory. Nearly all the samples which have been graded in the government grading rooms thus come to be checked over privately.

If the owner of the grain in a car, or his representative, is dissatisfied with the grade given by the IVimnipeg inspector, he may ask for reinspection. Owing to the fact 34 R. Magill, loc cit., pp. 41-42. 
that, as soon as a sample has been taken from any car, the car is dispatched to the head of the lakes without delay, it is necessary that reinspection of a car shall be made not at Winnipeg but at Fort William or Port Arthur. The negotiations to secure reinspection take place, therefore, whilst the car to be reinspected is moving forward to its destination. When a car is to be reinspected, the Inspection office at Fort William is notified, and, as soon as the car arrives, a new sample is taken from it and graded. There is no extra charge for reinspection.

If, after reinspection, the owner of the grain is still dissatisfied, he may appeal to the Winnipeg Survey Board. The members of the Board are recommended for their positions by the Winnipeg Board of Trade and by the Ministers of Agriculture of Manitoba, Saskatchewan, and Alberta; and they are all appointed by the Board of Grain Commissioners. The rules and regulations of the Surver Board are made by the Grain Commission. No appeal can be made on grain which has lost its identity by being mixed with other grain. If the inspector's grade is confirmed, the owner of the grain pays three dollars for the survey; but, if the grade is altered, there is no charge. A Survey Board, when once appointed, is independent during its period of office, and, in cases of contested grade, its verdict is final.

When the crop is of high grade, very few appeals are made; but, when the crop is of low grade, appeals may be as numerous as 2 per cent. Most of the appeals are made on what are known as tine grades, i. e., on samples which stand very high in a grade, near the line between its grade and the next higher one. When a sample is near a dividing line, the government inspector must decide the delicate question as to which grade the sample really belongs. Here, occasionally, there is some room for a dif- 
ference of opinion even among experienced graders. If, for instance, wheat which has graded No. 5 Wheat is a very good sample of wheat in that grade and is evidently very near the line separating No. 4 Wheat from No. 5, on reinspection it may happen that another inspector may put it in No. 4 Wheat; but this second inspector will doubtless consider it to be only a very poor sample of this higher grade and only just worthy to be included in it. Of the appeals made, only about one in ten result in any change being effected. Since owners of grain do not usually ask for reinspection of samples which are very low in their grades and which might on reinspection be put down a grade, the reinspections that are called for, if they result in a change at all, usually, but not always, result in a rise of grade and not a fall.

\section{Weighing Wheat}

It is just as important for a shipper of wheat to obtain accurate weights as it is to obtain accurate grades, for weighing, equally with grading, affects the total amount of money he will receive for his grain.

Weighing of grain may seem to be a very simple mechanical process; but, for various reasons, it is difficult to carry out with uniform success in western Canada. In the first place, grain is received into upwards of 3,000 country elevators, and it is weighed at every elevator; in the second place, the men who weigh the grain at the elevators are employees of the elevator companies and not of the State; and, in the third place, at the terminal elevators the grain is weighed after it goes into the elevator and not before.

In the terminal elevators, the work of the elevator weighman is supervised by a Government employee; but, 
on account of the number of weighmen who would be required, such constant supervision could scarcely be provided at the country elevators. As we have seen, if a shipper is not satisfied with the grade of his wheat, he can call for reinspection and appeal. Dissatisfaction with weights, however, cannot be so easily remedied. In most cases, wheat, after being weighed, is binned with other grain and cannot again be obtained as an entity for reweighing. It is only possible to re-weigh satisfactorily when there has been no leakage between the scale and the receiving pit or between the receiving pit and the scale, and when the wheat concerned has been stored separately.

The scales in the country elevators are inspected and approved by inspectors of the Inland Revenue Department; but there are so many elevators that it has not been possible to visit each scale and thoroughly inspect it more than about once a year. In addition to the fact that the scales are apt to get out of order, other difficulties connected with weighing are to be found in car damage and leakage, pilfering, and occasional dishonesty of one of the weighmen. Since a government official cannot be present to watch all the weighing that goes on in country elevators, and with a view to protecting the shipper, the Canada Grain Act provides that "persons interested in the weighing of grain shall have free access to the scales while such grain is being weighed." A farmer, therefore, if he chooses, can always supervise the weighing of his grain. Falsifying or misstating weights is heavily penalized; and, if a farmer is dissatisfied with the scale at a country elevator, he can apply for an inspector who will at once visit the scale and investigate its condition.

Some farmers have set up on their farms private scales of their own and weigh each wagon load of grain before hauling it to the country elevator. By this means they 
know what their grain should weigh on the scale of the country elevator and thus have a check upon the work of weighing performed by the elevator operator.

There is a Chief Weighmaster who has charge of all the weighing in Canada. His authority is exercised under the Board of Grain Commissioners. At the terminal elevators he is also the scale inspector and is thus responsible at the lake front not merely for weighing but for the condition of the scales.

A car of grain which has been shipped from a country elevator or a loading platform, is inspected for grade at Winnipeg but is not weigher officially until it arrives at Fort William or Port Arthur. When a car has been brought into place or spotted at the siding of a terminal elevator, it is at once examined for defects or leakages and, if such are found, a record is made of the car number and the condition. The seals on the doors are also observed and a record is made of their numbers and whether or not they are intact. The outer doors of the car are then drawn aside, the depth of the grain in the car is measured, and the load line noted. One or both of the grain doors are then removed, and the grain is unloaded into the grain pit. From this pit it is elevated to the hopper above the scale in the working house, and it is then weighed by the elevator company's weighman under the supervision of the Government weighman. A draft ticket which shows the amount which has been weighed, is then punched by the scale register. A record of the weight is taken, and upon this the certificate of weight is issued. ${ }^{35}$

XXI. Wrarehouse Receipts, Registration, and Stocktaking When grain has been received into a terminal elevator 35 Vide R. Mlagill, loc. cit., pp. 46-47. 
at the lake front, weighed, and binned, a warehouse receipt for it is issued to the person who delivered the grain. Upon this receipt is set down the place, the date, the shipping point, the name of the owner, the kind and grade of the grain, the net weight, and the car number.

The warehouse receipt is first sent to the registration office of the Board of Grain Commissioners at Fort William where it is compared with the inspector's report of the cars unloaded at the elevator in question. If found correct it is registered.

On receipt of the bill of lading, the warehouse receipt is given to the owner of the grain. When a shipper has obtained such a receipt: he may sell his grain, if not already sold, for cash; or make delivery of his grain, if sold, by handing over the receipt for a cheque; or use the receipt as collateral security for a loan from his bank.

When grain is passed out of a terminal elevator into a lake steamer or box-car, the warehouse receipt representing it must be presented to the registration office for cancellation within seventy-two hours after loading of the grain has been accomplished.

The registration records of the registration office show the total quantities of the varions grains by grades received into and shipped out of each elevator. The inspection and weighing departments also possess such records, so that the operations of each elevator are well watehed.

The Government, in carrying out its work of supervising the grain business, annually takes stock of all grain in each terminal elevator. In the month of Angust, officers of the Board of Grain Commissioners go into each elevator and make out statements showing the kinds, grades, and weights of the grain in each house. The registration clerks add up the receipts issued and canceled during 
the year; and thus, for every elevator, the annual surplus or shortage of grain is determined. The information so obtained is then published for the information of every one interested.

The Government in response to the demand of the grain growers for increased governmental control of the marketing of grain, erected in 1912-14 at Port Arthur an elevator with a capacity of $3,500,000$ bushels, and subsequently built other large terminal elevators at Vancouver, Moosejaw, Saskatoon and Calgary. Thus the Government procured, at first-hand, knowledge of the cost of elevator construction and operation. Farmers now have a wide choice of terminal elevators at the lake front. They may ship to an elevator operated by the Government as a public utility, to one of three elevators operated by their own trading companies, to an elevator owned by either the Canadian Pacific Railway, the Canadian Northern Railway or the Grand Trunk Pacific Railway, or, finally, to one of the elevators operated by a commercial company. ${ }^{36}$

\section{The Dominion Grain Research Laboratory}

The Board of Grain Commissioners was established to administer the Canada Grain Act of 1912. In the course of its work, it was continually encountering problems relating to grain which demanded solution by patient study and research, and its first chairman, Dr. Robert Magill, therefore advocated the establishment of a Grain Research Laboratory. As a result, the Laboratory came into existence at Winnipeg in the year 1914.

The Grain Research Laboratory is under the direction of Dr. F. J. Birchard, who is ably assisted by Mr. A. W. ${ }^{36} \mathrm{Cf}$. R. Magill, loc. cit., p. 54. 
Alcock and other investigators. It is equipped with an experimental mill, a fermenting cupboard, an electric baking oven, moisture testers of various designs, and much other apparatus. The chief aims of the laboratory are, firstly, to study problems which relate to the keeping qualities of grain when it is under transportation or in storage, and, secondly, to gather information which may be used as a basis for placing the grading of grain on a more scientific basis than has hitherto been possible.

It is often asked: What is the normal amount of moisture in grain? Does frosted wheat and immature wheat heat more readily than normal wheat of the same moisture content? How much moisture can the different grades of grain safely carry without heating in ears or boats or when stored in elevators? To these questions which are vitally important to the grain trade, some answer must be given every day. However, the problems suggested by them can only be solved by long-continued observations and careful scientific work such as is being carried out in the Grain Research Laboratory.

One of the experiments already made by Dr. Birchard and Mr. Alcock was the trial shipment of wheat in bulk from Vancouver to London via the Panama Canal; and, as we have seen, it was crowned with success.

Difficulties concerning the proper grading of grain are constantly coming to the fore. Thus, in the autumn of the great rust year, 1916, the comparative milling value of rusted grain and the baking qualities of the flour produced were matters of the greatest moment. This problem was immediately studied in the Grain Research Laboratory and the milling yields of the different grades at once published. An exhibition of loaves baked from the flour of rusted and non-rusted grain respectively was 
made on the floor of the Grain Exchange, so that all who were interested conld form their own opinion as to the value of the different grades for milling purposes.

Other questions in which the laboratory has become interested and which affect grading are these: That is the milling value of tough wheat and damp wheat as compared with straight-grade wheat? ${ }^{37}$ What are the most suitable temperatures for the drring of tough wheat and damp wheat? What ralue should be given in grading to spring-threshed wheat and to admixtures of grains showing special characteristics such as immature green grains, pink grains, black-pointed grains, and frosted grains? According to the Grain Act, wheat grading as No. 1 Northern, after being dried, cannot receive a higher grade than No. 3 Torthern: is this justifiable? How does the grading of flax seed correspond with the amount and quality of the oil extracted from each grade?

The Western Grain Standards Board, which is appointed by the Board of Grain Commissioners, sets the commercial grades ${ }^{38}$ of wheat each autumn from the first samples of the new crop brought to Winnipeg. Average samples are sent as soon as possible to Dr. Birchard who puts them through the usual milling and baking tests. He then submits a report to the Grain Standards Board for its guidance in setting the commercial grades. The results of the tests are published yearly at Ottawa in the Monthly Bulletin of Agricultural Statistics and also in trade journals.

37 Tough wheat is wheat which carries a large percentage of moisture. If the moisture is excessive, the wheat is known as damp wheat. In straight-grade wheat, the amount of moisture is normal. 38 The statutory grades of western spring wheat are: No. 1 Hard, No. 1 Northern, No. 2 Northern, and No. 3 Northern. The Standards Board defines wh additional grades as No. 4 Wheat, No. 5 Wheat, and No. 6 What, each having subdivisions. Vide supra, Section XVI. 


\section{The Winnipeg Grain Exchange}

One of the most important factors in facilitating the marketing of the wheat of the Canadian West is the Winnipeg Grain Exchange. This great institution was incorporated in 1891, and subsequently, in 1908, was re-organized as a voluntary association of grain dealers. At first there were only ten members, and the entrance fee was $\$ 15$; but now the members number more than three hundred, and the value of the seats has increased to $\$ 5,000$. So commanding a position has the Exchange now attained that the leading grain dealers on the continent feel it imperative to become members. The present Grain Exchange building is a fine and massive structure which cost $\$ 2,000,000$; and employed within its walls are more than fifteen hundred persons. ${ }^{39}$ The Exchange compiles, records, and publishes statistics; obtains and distributes information respecting the produce and provision trades; promotes and maintains uniformity in the business, customs, and regulations in these trades among those engaged in them; and adjusts controversies and misunderstandings arising between the traders. ${ }^{40}$ The Exchange spends thousands of dollars every year in its telegraphic communications with the consuming markets of the world, and every day posts on blackboards the prices prevailing at London, Liverpool, Paris, Buenos Ayres, Chicago, Minneapolis, Kansas City, and Duluth. Other statistical information is also being constantly received and given to the press. The prices prevailing on the Winnipeg market are telegraphed daily to at least four thousand points in the western provinces. All this information is given to the farmers without charge, so that

39 W. E. Milner, The President's Address, Eighth Annual Report of the Winnipeg Grain Exchange, Sept. 13, 1916, p. 29.

40 These functions are mentioned in the articles of incorporation. 
nearly all of the agricultural population are supplied with figures which enable sellers to dispose of their grain under conditions which they consider to be most advantageous to themselves. ${ }^{41}$ In $1915-16$ the Exchange was the largest of all the cash wheat markets on the American continent. $^{42}$ In that year nearly $\$ 500,000,000$ were distributed throughout the Prairie Provinces, and nearly all of this business was by verbal or telegraphic communication. So high, however, were the business ethics of the Exchange, that there was not an agriculturist who did not receive full money for his grain. ${ }^{43}$ Through the efforts of the Exchange, permanent standards have been secured for the various grades of grain, and these have proved of great benefit to producers and grain dealers alike throughout the West.

The Grain Exchange provides a most convenient meeting place for buyers and sellers. The sellers who act either directly or indirectly for the producers, are the elevator companies, farmers' trading companies, and commission men; while the buyers who represent the consumers, are the Canadian millers and exporters. The exporters sell to English or European mills either directly or through other grain exchanges.

The price of wheat is like the mercury in a barometer in that it is constantly fluctuating from hour to hour, from day to day, and from week to week. In neither case can even the wisest of men predict the changes in detail. The mercury in the barometer rises or falls in delicate response to the slightest alterations in the pressure of the atmosphere. The price of wheat on the Winnipeg Grain Exchange is equally sensitive to pressure of another kind: it goes up and down in srmpathy with the ever-changing 41 W. E. Milner, loc. cit., p. 27.

42 Ibid., p. 26.

43 Ibid. 
relation between the world's demand for and supply of the leading cereal, and it is also affected by variations in the facilities for transportation and in the conditions of the money market. All the fluctuations in price which result, operate to make fair values for every one concerned. The Exchange performs its part in influencing these fluctuations by giving to its buyers and sellers as much up-to-date information concerning world conditions affecting the grain trade as possible, and by posting up as the fair value at the moment the prices at which sales have just been made. ${ }^{44}$

The charge for selling wheat on the Winnipeg Grain Exchange is fixed by what is known as the Commission Pule. According to this rule, the rate for selling consigned wheat is one cent a bushel. The rate is uniform for every customer, and members of the Exchange are not permitted either to lower it or raise it. The commission rule has various advantages: it allows a seller to estimate beforehand what his selling charge will be, it prevents discrimination between customers, it compels keen competition in service, and it provides a fair reward for services rendered, thus reducing the temptation to dishonesty. ${ }^{45}$

Applications for membership on the Exchange are carefully scrutinized in order to prevent the entry of unscrupulous traders, for it is most important that the reputation of the Exchange for integrity in the dealings of its members should be kept as high as possible. If a member violates any of the rules or regulations, his conduct is inquired into and he may be disciplined even to the extent of expulsion.

$44 C f$. C. F. Piper, Principles of the Grain Trade in Western Canada, Winnipeg, 1917, pp. 177-178.

45 Ibid., p. 180. 
XXIV. The Geographical Position of the Grain Exchange

Owing to the peculiar geographical features of western Canada, the main lines of the railways in this vast territory have been built so that they converge toward Winnipeg and lead to Fort William and Port Arthur on the lake front. These ports are the natural points for the delivery of grain to be sold in bulk for export or for transportation to the eastern part of the Dominion. However, the Grain Exchange, where this wheat is bought and sold, is not located at Fort William or Port Arthur, where the wheat is stored, but at Winnipeg, a city situated 420 miles west of the lake front and therefore far from what would seem to be the natural market. Nowhere else in the world does a parallel case exist: in other countries the grain exchanges are all to be found where the wheat in which they deal is delivered. The separation of the Grain Exchange of westem Canada from its apparently natural market is unique, and it is therefore of interest to inquire as to its cause.

Fort William and Port Arthur are far away from the prairie land which produces the grain. For 400 miles immediately west of these twin cities the country is rocky and unproductive. On the other hand, Winnipeg is a large metropolis and a great railway and banking center, and it is situated between the grain fields and the lake front. It is therefore much more convenient to operate the grain trade from Winnipeg than from Fort William or Port Arthur. Exchanges of letters can be made much more quickly, and telegrams sent more cheaply, between country points and Winnipeg than between those same points and the lake front. Moreover, Winnipeg is the center of a set of long-distance telephones which radiate in all directions and thus enable many farmers and their 
agents to communicate with members of the Grain Exchange directly; but were the Exchange at the lake front, such communication, owing to distance, would be very much more restricted. The buyers are relatively few, while the farmers or producers are relatively numerous. It is, as Piper ${ }^{46}$ says, "easier to bring the concentrated portion of the business from Fort William and Port Arthur to Winnipeg than it is to take the divergent and extended portion of the business from the grain fields in the west to Fort William." The buyers can operate with relatively slight inconvenience to themselves at a distance from the terminal elevators, whereas, if the farmers and those who represent them were obliged to travel an extra 420 miles to the lake front when they wished to visit the Exchange, they would be put to a very considerable extra expense and loss of time. It is therefore not surprising, all this being considered, that the most important and largest Grain Exchange of the TVest is situated at Winnipeg and not at Fort William or Port Arthur.

\section{|XXV.|The Grain Exchange Clearing House}

For various reasons it is often necessary for grain dealers to deal in what are known as futures, i. e., to buy or sell grain which is to be delivered to the purchaser during some future month. Thus, in August, a miller might buy September wheat, i. e., wheat that must be delivered to him in September, or October, November or December wheat, i. e., wheat that must be delivered to him in the months of October, November, or December respectively; and in the winter he might buy May wheat, i. e., wheat that must be delivered to him in May, and so 46 C. B. Piper, Principles of the Grain Trade of Western Canada, p. 171. 
forth. Of course, pure speculators may and often do speculate in wheat as in other things in the hope of anticipating the movements of the market and thereby making money; but, apart altogether from such speculations, dealing in futures is, under normal conditions, an absolute necessity for the grain trade. Millers, for instance, in order to regulate the output of their mills, must anticipate their needs for wheat to grind into flour often months before they are ready to have the grain delivered to them, and accordingly must deal in futures. Sometimes it is necessary first to buy wheat and then sell it again. Thus if in August a miller has bought, let us say, more October wheat than he finds he can actually store when October is approaching, he may be obliged to hedge, i. e., sell his October wheat and buy wheat to be delivered during a later month such as November or December. ${ }^{47}$ Dealing in futures is not merely advantageous to the domestic miller but plays an essential rôle in the business of exporting wheat to foreign countries from the terminal elevators.

Within the Grain Exchange is an independent corporation known as the Winnipeg Grain Exchange Clearing

47 The term hedge really means to protect and is applied to all kinds of transactions made to prevent loss due to fluctuations of the market. For the sake of illustration, let us suppose that an elevator owner has sent a number of agents into the country who have purchased wheat from various farmers, and let us further suppose that the wheat so purchased is not due to arrive at Fort William until several months have elapsed. In the interval the market may fluctuate seriously. To avoid possible loss, the owner of the wheat may hedge, i.e., sell the grain which he has purchased for delivery in a future month. When he has done this, he knows exactly what his obligations are in respect to the wheat he purchased but has now sold, and whether he has made a loss or profit from it. In any case, as the fluctuations of the market under normal conditions are small, his loss or profit can only be relatively small also; but the intention in hedging is to avoid undue risks. 
House. This corporation performs most important functions, for it greatly simplifies and facilitates trading operations between the members of the Exchange and, at the same time, provides absolute security in all transactions concerned with the future delivery of wheat or other grains. The principle of the Clearing House is that for every contract which the Clearing House accepts, the Clearing House becomes seller to the buyer and buyer to the seller. In carrying out this principle, the Clearing House with all its resources comes to stand solidly behind every accepted contract. The result of this is that a person who buys or sells grain for future delivery can rest assured that, so long as he is willing to fulfill his part of the contract and provide the necessary security against the fluctuations of the market from day to day, if he is a buyer, on the contract date the grain will be ready for him to receive, and, if he is a seller, on the contract date a buyer will be ready to take delivery of his grain and pay him for it.

Some of the features of a single transaction may first be considered. Let us suppose that a grain broker buys for a customer 5,000 bushels of May wheat and that the price of May wheat at the time he wishes to make the purchase is about $\$ 1.54$ per bushel. He assembles with other brokers in the wheat pit on the floor of the Exchange. A seller may say "I'll sell May wheat at fiftythree and a half!" By this he means that he offers for sale 5,000 bushels of wheat to be delivered in May at the price of one dollar, fifty-three and one-half cents per bushel, the unit amount of wheat offered being always understood as 5,000 bushels unless some other amount is specified. ${ }^{48}$ If the purchaser says "Sold!" the sale is

48 The standard contract grade of wheat on the Winnipeg Grain Exchange is No. 1 Northern, but No. 2 Northern and No. 3 Northern 
considered made. The buyer enters up the transaction on a card at once and the seller does likewise. Then, in their offices, they each make up a clearing sheet. At the end of the working day, each sends his sheet to the Clearing House where it must be deposited by a specified time early in the afternoon. As soon as the Clearing House has accepted the transaction as recorded on the clearing sheets, the particular buyer and seller part company so far as their transaction is concerned, and have nothing more to do with one another. The seller has contracted to deliver 5,000 bushels of May wheat, i. e., to deliver this amount of wheat some time in May, on any working day. He waits until the month of May arrives, and then when he is ready, his 5,000 bushels of wheat being now stored in a terminal elevator at Fort William or Port Arthur, he goes to the Clearing House and tells the Manager that he has his wheat ready for delivery. The Manager then looks through his books and finds some one who bought 5,000 bushels of May wheat and whose turn it is to take delivery, the turns being arranged in the order of buying. He then informs this buyer that such and such a seller, our original seller, wishes to deliver 5,000 bushels of May wheat to him and he informs the seller who it is to whom his wheat is to be delivered. Then it is the duty of the seller to deliver his wheat to the buyer with whom the Clearing House has brought him into contact, at once. The Clearing House has then finished its dealings with the buying and selling contracts here involved, but the seller and buyer only end their business when the seller delivers an invoice with the warehouse receipts for the wheat and the buyer hands the seller a marked check for the amount due. The receipts show that the wheat are deliverable thereon at arbitrary discounts of three cents and eight cents respectively. This is a fair rule to protect sellers. Vide C. F. Piper, loc. cit., p. 150. 
of which the buyer now gets possession, is in storage in an elevator at Fort William or Port Arthur on the water front of Lake Superior. We thus see that the 5,000 bushels of wheat that were originally bought in the transaction in the wheat pit have gone not to the original buyer but to some one else. Having now disposed of the original seller in the transaction in the wheat pit, let us turn our attention to the original buver. How does he obtain the 5,000 bushels of wheat which he purchased? The original buyer waits until May until his turn to receive May wheat arrives. The Manager of the Clearing House then informs him that a certain seller has 5,000 bushels of May wheat to deliver and that he is to accept this wheat from this particular seller, and he also informs the seller that he is to deliver his wheat to our original buyer. It is then the duty of the original buyer to accept the 5,000 bushels of wheat from the seller with whom the Clearing House has brought him into contact; and this second pair of buyers and sellers, like the first pair, completes the transaction with a marked check and a warehouse receipt for the grain. The wheat delivered is always of just the same grade and quality as that originally purchased, so that in the end nothing it lost by the substitution of one seller for another at the time the delivery of the wheat is made.

The Clearing House system, as it affects traders, in simplifying their transactions in respect to future deliveries of wheat, and in guaranteeing security for the fulfilment of such transactions, may be thus described. Every member of the Clearing House is bound at the end of each working day to send in a sheet showing purchases made, the names of the vendors, and the prices. He must also send in another sheet showing the sales he has made, the names of the purchasers, and the prices. The amounts 
of each sheet are totaled and entered in a recapitulation sheet, and upon this sheet is then set out a balance of excess of purchase over sale or vice versa. The difference between the price on the sheet and the closing market price is then worked out and this difference is paid within one hour by the Clearing House to the member or vice versa as the case may be. And thus, on the next day, the purchase or sales sheet of the member will bring a balance forward. Upon these new sheets the day's transactions will be set, the sheets will be forwarded to the Clearing House at the close of trading, and the transactions settled as before. Thus from day to day, after a contract has been entered into, if the market drops, a purchaser will be required to pay the difference to the Clearing House, or, if the market rises, he will receive the difference each day from the Clearing House. This daily payment of differences is continuously made until the contract month arrives. If now the member wishes to take delivery of his grain, he notifies the Clearing House which causes a warehouse receipt for the grain he has bought to be handed over to him from an indicated seller and he pays for the same to the seller at the current market price. If this current market price is higher than the price he contracted to purchase at, he is not a loser, because, during the time the contract was open, he has received from day to day the difference between the price at which he bought and the market price of the day. If, on the other hand, the current price is lower than the price he has contracted to purchase at, he is not a gainer, because, during the time the contract was open, he has paid to the Clearing House the difference between the price at which he bonght and the market price of the day. Similarly, a seller, at the final settling, when he gives up his warehouse receipt to the purchaser, may receive a lesser or greater price for his wheat than that he 
contracted for; and yet he is neither a loser in the one case nor a gainer in the other, for the differences involved have been already settled with the Clearing House during the time the contract was open.

The Clearing House system permits of the same wheat being bought and sold a number of times within a season and a single warehouse receipt, say for 5,000 bushels of wheat, may have an adventurous career in passing through a long series of brokers' offices. In a single year, indeed, the amount of wheat bought and sold on the Exchange may be several times the amount of the entire available crop. ${ }^{49}$ Yet, in the end, the final purchasers all obtain the wheat they have contracted to buy, at the proper moment and without fail. The system of the Clearing House, owing to the security which it affords, allows of transactions being made closer to the margin of necessary profit than would otherwise be possible, with the result that farmers obtain a higher price for their grain than they could if no such system were in operation.

The Clearing House makes it its business to know the financial standing of its members and any failure of a member to live up to his contracts is visited with instant punishment. If a member should appear to be plunging

49 From this no inference can be drawn that the transactions in futures are necessarily unduly speculative or gambling in their nature. Thus a miller who has bought more October wheat in April than he finds in August he is likely to be able to grind in view of orders received since the date of purchase, may sell in August the excess for delivery in October to some one else. In September, however, he may find that, after all, owing to the receipt in that month of unexpectedly large orders for flour, he may require, in order to meet these orders, even more October wheat than he has sold. $\mathrm{He}$ therefore once more goes into the market and again purchases October wheat. Thus a part of the original purchase of October wheat in April and of his sale of the same in August simply become book entries which go to swell the entries in the Clearing House records and to increase the total volume of buying and selling but which do not affect the amount of the actual grain involved. 
into transactions beyond his financial depth, he may be called upon to deposit immediately with the Clearing House a check sufficiently large to protect the Clearing House against the fluctuations of the market; and, if he fails to do this, the Clearing Hlouse may close out all his transactions. In the event of failure to carry out a contract, his seat may be sold and he may be excluded from the privileges of the Exchange. The Clearing House finds it all the more necessary to make stringent rules and regulations regarding the conduct of its members since any failure of a member to carry out a contract must be made good by the Clearing House itself.

\section{The Wheat Pit}

One of the most interesting sights in Winnipeg, under normal trading conditions, is the wheat pit in the Grain Exchange. The pit is in direct telegraphic communication with all the leading markets of the world, and the changes of prices at Chicago, Minneapolis, Liverpool, etc., are kept posted up on raised blackboards. Overhead sounders which tick out messages in the Morse Code, keep the men at the blackboards constantly in touch with the trading in Winnipeg and other centers; and, during trading hours, the blackboard men scarcely have a moment's rest. When I visited the Exchange in November, 1916, trading was very active and the excitement was great, for wheat was selling at a higher price than any that had been known since the American Ciril War. December wheat was selling at $\$ 1.94$ and November wheat at $\$ 1.99$. Some eighty or a hundred traders were in the pit which, from the gallery where I was ensconced, seemed like pandemonium let loose. All seemed confusion. The hubbub was continuous. A number of the traders were shouting at the top of their roices, flinging up their hands, gesticulating 
with their fingers, springing up and down, seizing one another by the shoulders, making notes of sales, and sending off telegrams; but, for a long time, not one coherent word reached my ears and I could never tell whether a man was selling flax, oats, barley, or wheat. The members of the Exchange were evidently communicating with one another in an unknown language. Telegraph boys were rushing from the traders in the pit to the adjacent telegraph office which stretches from one end of the trading room to the other. Here the ticking never ceased for an instant, and more than twenty clerks behind a long counter were busily employed dispatching messages. The boy in charge of the numerous telephone stations summoned traders who had been called, by crying their names through a speaking trumpet, for that was the only means of making a summons heard above the din of the wheat-pit. I particularly noticed one man who appeared desperately anxious to buy May oats, for he jumped up and down as fast as he could more than twenty times in succession, and yelled again and again at the top of his voice: "Sell May oats! Sell May oats! Sell May oats!" Whether or not he obtained what he wanted, I am not sure, for after the most prodigal expenditure of physical energy he subsided, possibly from exhaustion, and I lost sight of him in the crowd. High above the long stretch of blackboards at one end of the trading room where the blackboard men were continuously rubbing out old figures and chalking in new ones, was a large dial, something like the face of a clock. Upon it, in letters made red with electric light, stood out the syllable Dec. which stands for December wheat, i. e., wheat that must be delivered in December. And above this was the figure 3 which, by reference to the blackboard, could be understood as standing for the 3 in the price of $\$ 1.93$. Then around the edge of the dial was the price of Decem- 
ber wheat in eighths of one cent. If the price was $\$ 1.93$ and $1 / 8$, the $1 / 8$ was lighted up with red, if $\$ 1.93$ and $3 / 8$, then the $3 / 8$ was lighted up, and so forth, so that one could read off the price at which December wheat had just been sold. The wheat-clock is manipulated by the recorder, a grave man who sits at a high desk overlooking the wheatpit, and who, with the help of two assistants, keeps an accurate account of what trading is done by the often frantic men down below. He it is who interprets the unknown language of which I have spoken, who by electric switches records the fluctuations in the price of sales on the wheat-clock, and who provides the trading statistics for the reports of the Exchange.

\section{The Effect of the War on the Grain Trade}

The influence of the war upon the grain trade of Canada and the United States has been profound. Indeed, it has resulted in nothing less than a revolution in the normal methods of marketing grain. This subject has been dealt with at some length by the three last Presidents of the Winnipeg Grain Exchange in their annual addresses, and these addresses have formed the chief source of the writer's information for what follows.

The outstanding feature of the marketing of grain in North America during the years of peace was the development of the grain exchanges. Their organization was due to commercial evolution and they were not created by governments. They supplied an economic want. It was the grain exchanges that found the way to collect grain at country points, assemble it in vast quantities at the terminal points, and distribute it among the mills of this continent and the mills of Europe; and it was the grain exchanges that developed the system of insurance against fluctuation in prices known as future trading, that made 
possible the financing of grain by the banks without incurring undue risks, and that in time developed the most complete machinery for taking the grain from the producer and putting it into the hands of the consumer at the lowest possible cost. $^{50}$

The machinery of the grain trade, created as it was by commercial evolution in times of peace, is well adapted to peace conditions but is liable to be thrown out of gear by such a war as that now happily being brought to a conclusion. The effects of the war on this machinery at first were not very marked, but they gradually increased in importance until, in the end, the whole system of marketing grain in North America was revolutionized to a degree which in ante-bellum days would have been considered impossible and almost inconceivable.

Soon after the war broke out, ocean tonnage for carrying grain became scarcer owing to the demands made on shipping for transporting troops and munitions. At the same time, there was a stiffening in ocean freight rates and marine insurance, and a considerable disturbance in the international rates of exchange. Under these conditions, the exporting of wheat from North America became a most difficult matter.

About the 28th of November, 1915, just before the close of navigation on the Great Lakes, the Dominion Government, through its Department of Trade and Commerce, commandeered all the wheat at the head of the lakes. This action, the first of its kind in the British Empire, came so suddenly, so unexpectedly, and at such a critical time of the year that it almost caused a panic among the grain traders, and it was found necessary to close the Winnipeg Grain Exchange for twenty-four hours. Owing to the 50 J. C. Gage, The President's Address, Ninth Annual Report of the Winnipeg Grain Exchange, Sept. 12, 1917, p. 35. 
interference with contracts that resulted from the Government's action, losses were caused both to members of the Exchange and to farmers; but it was recognized that the financial sacrifices involved were being made as the result of a war measure which had been taken in good faith with a view to assisting the British Empire and the Allies in their great struggle for the cause of liberty. ${ }^{51}$

The rising prices of bread in the United Kingdom, as in other Enropean countries, soon forced the British Govermment to consider ways and means of protecting the consumer, and the British Government decided to create an agency upon this continent for the purchase of wheat. The result was that a company - the Wheat Export Company - was named at Winnipeg in 1916 and authorized to purchase wheat for the United Kingdom. At a later date, this Company was entrusted with the buying of all the wheat for the Allies in Europe, especially for Great Britain, France, and Italy. When this stage was reached, the exporters of wheat in Canada found themselves deprived for the time being of their business, and an important section of the grain trade was thus made to feel the full consequences of the war. 52

The Company that purchased for the European Allies made use of the machinery of the grain exchanges. It bought for future delivery in the ordinary commercial way; but, representing as it did the treasuries of Great Britain, France, and Italy, its operations were upon an enormous scale. During the times of peace in which the grain exchanges had been developed and had taken care of the wheat of the continent of North America, no company had ever appeared which had behind it such immense resources, which had furnished to it orders for such tre-

51 W. E. Milner, The President's Address, Eighth Annual Report of the Winnipeg Grain Exchange, Sept. 13, 1916, p. 25.

52 J. C. Gage, loc. cit, p. 36. 
mendous quantities of grain, and which consequently had such a predominating place in the exchange markets. ${ }^{53}$

The representatives of the Wheat Export Company were buying through the winter and spring months of 1916-17 for May and July delivery; and, of course, they were not the only buyers, as the Canadian mills were doing the same. A situation then arose which, as the month of May, 1917, approached, brought to a head the accumulating effects of the war upon the grain business of Canada. The gatherers of grain at country points had hedged their holdings in the usual way. Much of the grain so hedged did not come up to the contract grades; and the result was that, as the month of May approached, there was heavy bidding for the contract grades, and prices went skyrocketing. On Saturday, April 28, 1917, May wheat opened on the Winnipeg Grain Exchange at $\$ 2.71$. Within two minutes, and at the first trade, the price was $\$ 2.82$; and in 23 minutes, and at the fifteenth trade, it was $\$ 2.86 .{ }^{54}$ The maximum closing price for May wheat, namely, $\$ 3$ per bushel, was attained on each of the two days, May 11 and May 12.55 Had the holders of May and July wheat stood out for their pound of flesh, they would have brought about a disaster to the Canadian grain trade and, as it appeared later, to the grain trade of the whole North American continent, unparalleled in commercial history. To avoid this, the Winnipeg Grain Exchange took hold of the situation and the result was the next profound effect of the war upon the grain trade. ${ }^{56}$

The rising prices of wheat, accompanied as they were by parallel increases in the cost of flour, produced a clamor amongst the consumers of the country, and, as usual, this 53 Ibid.

54 Ninth Annual Report of the WVinnipeg Grain Exchange, p. 66.

55 Ibid., p. 120.

56 J. C. Gage, loc. cit., p. 37. 
clamor was very largely directed against what is popularly called speculating or gambling in the bread of the people. The Winnipeg Grain Exchange, on April 28, 1917, therefore appointed a Censoring Committee whose duty it was to ascertain accurately the extent and character, if any, of illegitimate speculating in wheat. Very little of such business was found by the Committee. The appointment of the Committee created considerable surprise and resulted in a fall of prices; but this fall was only temporary and soon prices began to mount skyward again.

Shortly after hearing the Report of the Censoring Committee on May 3, 1917, the Winnipeg Grain Exchange decided upon the fateful step that took away the facilities for future trading in wheat in the Winnipeg Grain Exchange, and proceeded to take all the other steps rendered necessary thereby ${ }^{57}$ The last closing price was taken as a basis of closing trades in the Clearing House; and, after a great deal of trouble, the May and July accounts were all cleared as satisfactorily as it was possible to clear them to the various interests involved. Negotiations took place with the longs and the shorts, with the scalpers and the spreaders, and with the agencies that were gathering the grain throughout the country. The Wheat Export Company met the Exchange in a generous way; and the agencies which were collecting the grain in the country, guaranteed to sell 90 per cent. of all the wheat they controlled for the balance of the crop year to the Export Company. Many members of the Exchange were financially injured, vet all the members were dominated by one spirit, the spirit of give and take, and of doing the best in the interests of the country during the period of the war. ${ }^{58}$

57 The Ninth Annual Report of the Winnipeg Grain Exchange, Sept. 12, 1917, The Council's Report, pp. 64-73.

58 Cf. J. C. Gage, loc. cit., pp. 38-39. 
The major causes of the crisis at the Grain Exchange which resulted in the withdrawal of the facilities for future trading were war causes, although the intensity of the crisis was increased by the fact that much of the hedged grain did not come up to the contract grades. These war causes, as summarized by Gage, ${ }^{59}$ may now be discussed.

To begin with, there was a loudly proclaimed shortage of the supply of available wheat. This shortage was emphasized in the speeches of some of the most prominent men in the British Empire and also in the United States. Ministers of the Imperial Government, high officials in both countries, and hundreds of newspaper editors laid stress on the fact that the surplus wheat in Russia was locked up by the war, that the surpluses in such countries as India and Australia were not available through conditions of transportation, and that Argentina had no surplus at all. They proclaimed the dependence of the European allies, so far as wheat is concerned, upon the continent of North America, and they devised ways and means of eliminating waste, of husbanding their resources, and of persuading or coercing their peoples to use substitutes for the white bread to which they had become accustomed.

Next, there was the imperious need of the allied peoples for Canadian wheat at a time when their men in uniform had been withdrawn from productive work, thus causing a labor shortage in agriculture as in other interests on the one hand, and on the other increasing the normal consumption of bread. The soldiers at the front must be fed and well fed; the workers in the United Kingdom were demanding and receiving higher wages; the ranks of the workers had been increased by thousands and hundreds of thousands of women workers, so that the masses of the 59 Ibid., pp. 39-40. 
people in the Lnited Kingdom had more money to spend than for some years previously.

Next the war had affected profoundly the money situation, and, in so far as currency had been inflated or increased in any of its forms, higher prices were inevitable.

Lastly, it must be noted that the concentration of the buying for the European allies had been only slowly carried out and imperfectly at best. For example, in the Winnipeg market there were some who bought wheat for the Belgian Relief Commission; there were others who bought wheat for France; others again who bought wheat for the United Kingdom, and these were buying in open competition with one another. Further, these agencies were buying not only in competition with one another, but also in competition with Canadian millers and American millers, who themselves were buying wheat to fill flour sales to the same Allied Governments.

It was inevitable that a crisis should develop under such conditions as these, and the only wonder is that it was not worse.

The action of the Winnipeg Grain Exchange in taking away the facilities for future trading in wheat did not at first commend itself to the other grain exchanges of North America; indeed, the tendency in the exchanges of the United States was to question the wisdom of the steps taken in Winnipeg. It soon appeared, however, that the whole grain trade of this continent had been swept within the area of trouble, and within a very few days the leading exchanges of the United States were forced to take steps almost identical with those taken at Winnipeg. ${ }^{60}$

The price of wheat soared upwards on the grain exchanges of the United States just as it did at Winnipeg. At Chicago, the highest price for cash wheat, namely $\$ 3.43$ 60 Ibid., p. 40. 
per bushel, ${ }^{61}$ was attained on May 12, 1917 ; whilst, on the same day, at Minneapolis, the price of One Hard wheat ranged from $\$ 3.49$ to $\$ 3.54$ per bushel. ${ }^{62}$

The Winnipeg Exchange was the first in North America seriously to investigate the question as to whether or not there was any illegitimate gambling going on in wheat in war time; it was the first to take steps to prevent prices going higher still; and it was also the first to work out and apply the remedy to the situation, the only remedy at its disposal. By virtue of its actions during the crisis, the Winnipeg Grain Exchange gained in the esteem of the general public. Responsible men in all lines of business gave expression to their opinion that the Exchange had acted wisely and well under very difficult circumstances, and it dawned upon the public in general that the men engaged in the grain trade might be just as conscientious and just as patriotic as the men engaged in any other lines of business in the world. Certainly, the action taken by the Exchange contributed largely to the fact that the Government at Ottawa was prepared to give a sympathetic hearing to the representatives of the Exchange on the whole matter of the marketing of grain during war time. ${ }^{63}$

The next great effect of the war upon the grain trade of North America was the beginning of government regulation of the grain business. Every European country engaged in the war had found it necessary to undertake the regulation of grain supplies, grain distribution, and grain prices. Thus the period of state regulation was inaugurated in the warring countries of Europe one after another, and the mounting prices of bread upon this con-

61 The Board of Trade of Chicago, Sixtieth Annual Report for the year ending Dec. 31,1917 , p. 64.

62 Minneapolis Chamber of Commerce, Thirty-fifth Annual Report for the year ending Dec., 1917, p. 71.

63 J. C. Gage, loc. cit., p. 41. 
tinent and the action of the grain exchanges compelled the governments of the United States and Canada to consider what they could do under the circumstances. In the United States, a food controller, Mr. Herbert Hoover, was appointed and the Food Control Bill tabled, with the result that there was created the United States Grain Corporation which was put in charge of the most gigantic wheat monopoly the world has ever seen.

The United States Grain Corporation became the only buver of wheat at the great terminal markets and the only seller and distributor of wheat from these markets to the American mills, the European allies, and the neutral countries. In the United States the exporters were first thrown out of business. Then it was decided to create the Grain Corporation. Then, by a Commission appointed by the President, prices were fixed at which the Corporation was to buy all the wheat. Then future trading was prohibited. And, finally, the mixing of the grades of grain at the great terminal markets was made impossible. If there is added to this the fact - although this was not due to the war that the United States Government had taken over the matter of the inspection of grain, had standardized the grade, and had taken the inspection out of the hands of the different state legislatures, boards of trade and grain exchanges, it is not difficult to realize that the war has absolutely revolutionized the whole grain business of the United States. In the spring of 1914, no one could have imagined that, as the result of a European war, the United States Government would purchase all the wheat in the United States; that a government body would fix the prices; that the government would prohibit future trading; and that the government would prevent mixing of the grades, which was the very foundation of the great sample markets of the United States. Yet this is what actually happened. ${ }^{64}$

$64 \mathrm{~J}$. C. Gage, loc. cit., pp. 42-43. 
In Canada a different course was followed. The Government of Canada took into conference representatives of the producers and also of the trade, and especially of the Grain Exchange. The Government heard all that the most experienced members of the Exchange had to say about the marketing of grain, and, as a result of these negotiations, the Government of Canada, on June 11, 1917, created a body called the Board of Grain Supervisors for Canada, and clothed it with certain authority by an Orderin-Council under the Defense of the Realm Act. The Board, on the one hand, is not a great buying corporation like the United States Grain Corporation and, on the other hand, it does not usurp the functions proper of the Board of Grain Commissioners. It is a regulating body not an operating body. Its primary functions are: (1) to regulate the price at which grain shall be bought and sold during the period of its existence, and (2) to regulate the distribution of grain so that the grain will go to the Canadian people and the Allied powers. It has sometimes been said that the Board has power to commandeer all the grain in Canada. It has no such power: it cannot go to the farm, for example, and commandeer the wheat there, and its power to commandeer at elevators is a power to enforce the price it has set. If the owner of the grain that is in an elevator refuses to sell at the price set, the Board has power then to take the grain at that price. ${ }^{65}$

The Board of Grain Supervisors at first consisted of eleven members but now consists of twelve. Six of these twelve members are not members of the Winnipeg Grain Exchange. Of these six, one is the President of the $\mathrm{Ca}$ nadian Council of Agriculture, one a member of the Board of Grain Commissioners, one is the representative of the unorganized farmers, two represent labor organizations in 65 Ibid., p. 43. 
eastern Canada, and the sixth represents the remaining body of eastern consumers. Of the six members of the Board who are also members of the Winnipeg Grain Exchange, one is the General Manager of the Saskatchewan Co-operative Elevator Company, one is the President of the Wheat Export Company which buys for the Allies, and one represents the flour milling interests.

In accordance with its authority, the Board of Grain Supervisors has fixed the price of wheat from time to time. On July 20, 1917, the Board by its first Order fixed the maximum price of wheat, on the basis of One Northern in store at Fort William, at $\$ 2.40$ per bushel, the order becoming effective on August 1, 1917.66 The Board then issued Orders that trading in wheat for future delivery should cease in the Grain Exchanges of Canada on September 1, 1917, and that the price of wheat on that date, on the basis of One Northern in store at Fort William, should not exceed and not be less than $\$ 2.40$ per bushel. ${ }^{67}$

On September 12, 1917, the Board of Grain Supervisors fixed the price of wheat to accord with the fixed prices in the United States as follows: ${ }^{68}$

Fixed Prices of Wheat per Bushel from September 12, 1917, Until August 31, 1918, Inclusive

\section{Canada}

(basis Fort William and Port Arthur)

1 Manitoba Northern.. \$2.21

2 Manitoba Northern. . $\$ 2.18$

3 Manitoba Northern.. \$2.15

1 Alberta Red Winter. . $\$ 2.21$

2 Alberta Red Winter. . $\$ 2.18$

3 Alberta Red Winter. . $\$ 2.15$

\section{United States}

(basis Duluth and Minneapolis)

1 Dark Northern......\$2.21

2 Dark Northern..... \$2.18

3 Dark Northern...... \$2.15

1 Dark Hard Winter. . \$2.21

2 Dark Hard Winter.. $\$ 2.18$

3 Dark Hard Winter.. $\$ 2.15$ 66 Memoranda of the Board of Grain Supervisors of Canada, Order

No. 1, issued at Winnipeg, July 20, 1917.

67 Ibid. Order No. 3 and Order No. 4, both issued August 17, 1917. $68 \mathrm{Ibid}$. Order No. 5, issued September 12, 1917. 
The fixed prices of wheat were slightly increased for the 1918 crop both in Canada and the United States. In Canada the fixed prices for the three first grades for the crop year 1918-19 have been fixed as follows:

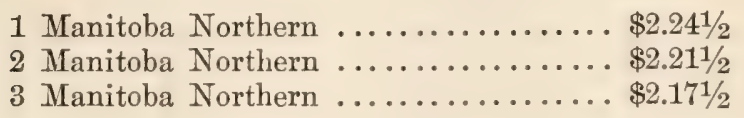

In addition to fixing the prices of wheat, the Board of Grain Supervisors, in conjunction with Mr. Hoover's department, put into effect the regulation of the export of wheat between Canada and the United States.

By an Order-in-Council on September 5, 1918, the Dominion Government took over the control of the marketing and handling of grain within the Dominion. The Orderin-Council vests authority in the Board of Grain Supervisors in regard to grain consumed in Canada and grain exported to the Allies. It provides that the agent for the Allied Governments must negotiate with the Board in regard to exported grain, and the Board can specify the place at which the Allied Governments shall accept delivery, the prices, and the terms. It also increases the power of the Board of Grain Supervisors with regard to grain consumed in Canadian mills, and, in a word, through the Board of Grain Supervisors the Government of Canada in the Order-in-Council takes control of the whole movement of grain. ${ }^{69}$

Sooner or later it seems certain that the grain trade will return to the condition in which it was before the war when the prices of wheat were not fixed but fluctuated in accordance with demand and supply.

69 W. R. Bawif, The President's Address, Tenth Annual Report of the Winnipeg Grain Exchange, Sept. 11, 1917, p. 43. 


\section{Financing the Crop Movement}

The grain which a farmer raises in western Canada, represents a very large part of his yearly revenue, and it is therefore most important that he should be able to sell it for eash soon after it has been threshed. Money is the universal medium of exchange; and the farmer requires it to pay those who assist him in his work, to buy horses, cattle, implements, machinery, etc., to erect farm buildings, and to purchase all the necessities requisite for the existence and comfort of himself and his family. ${ }^{70}$

The farmer naturally desires to be supplied with money as he requires it, and the problem of giving him cash for his wheat, whenever he wants it, is a considerable one. The ultimate consumer, as represented by the miller, does not buy at once all the wheat he can make use of for a whole year, because, if he did, he could not store it all and could not pay for it all in cash. If the ultimate consumer were to pay the farmer for his grain, the farmer would be badly inconvenienced in his farming operations by the necessity of waiting for deferred payments. Months would elapse between the delivery of the grain to a country elevator or into a box-car and the receipt of the money which would be owing to him. It is therefore clear that some agency must step in between the farmer and the consumer, which will give the farmer cash for his wheat as he requires it and carry the grain until the consumer uses it and pays for it. This agency, acting indirectly, is the bank.

The amount of credit used to move the grain crop of

$70 \mathrm{C}$. B. Piper has discussed the principles involved in financing the crop movement in his Principles of the Grain Trade of Western Canada (pp. 183-191) and his discussion has been of considerable assistance to the author in writing this Section. 
western Canada each year is usually about $\$ 100,000,000$. This vast sum is required for seasonal use only and could not therefore be provided profitably by the grain trade. It costs from $\$ 7,000$ to $\$ 12,000$ to build a country elevator which will hold 30,000 bushels of wheat. If the price of wheat in the country were 75 cents per bushel, it would require $\$ 22,500$ to pay for enough to fill a single elevator. Noreover, an elevator usually is filled for a part of the year only. If an elevator company were obliged to maintain a fund of $\$ 22,500$ per elevator all the year round, so as to fill each elevator for part of a year only, this capital would be badly employed and would yield a very poor rate of interest: it could be more profitably spent in some other business. Similarly, commission merchants and track buyers cannot afford to keep capital in large sums available for mere seasonal use. It is therefore obvious that the grain trade is unable to finance the crop movement without external aid.

Credit is the commodity of banks, and the business of providing credit for financing the crops therefore naturally falls to these institutions. The banks collect small deposits from a large number of people and then lend out the money so accumulated to those who require it for carrying on trade and commerce. The depositors receive from the banks a certain rate of interest and the borrowers are charged by the banks a higher rate of interest. The sum gained by the difference in rates of interest serves to pay the expenses of the banks and to ensure a profit upon their operations. At the same time, the money which the banks handle, is made to work both for the depositors and the borrowers. When the money is needed to buy the grain as it leaves the farms, the banks make temporary loans to the elevator companies, the commission merchants, and the 
track buyers, who pay interest for it. When the money is repaid to the banks, the banks use it again elsewhere in other seasonal businesses.

The financial business of forwarding the grain of western Canada to the miller is split into four sections: (1) from the farm to Fort William and Port Arthur, (2) from Fort William and Port Arthur to the seaboard or domestic miller, (3) from the seaboard to the foreign grain exchange, and (4) from the foreign grain exchange to the foreign miller. The banks of Canada, through their western branches, so far as the crop movement is concerned, practically confine themselves to financing the crop from the farm to the head of the lakes.

When the movement of the grain from the farms has once begun and the use of credit has become extensive, it is very important that the grain should be kept moving to the lake front as fast as possible. The quicker the grain can be moved to the lake front and sold for cash, the shorter is the time during which the money required to move the grain is employed, and the sooner is this money arailable for other purposes. It is theref re to the advantage of every one connected with the grain trade, both grain dealers and transportation companies, to keep the grain moving as fast as possible and thus keep credit turning over. The principle of finance here involved is called velocity of credit. ${ }^{71}$ The faster dollars are turned over, the more work do they perform in a given time and the greater are their earning powers. Instead of attempting to finance the western Canadian crop to the seaboard or to foreign grain exchanges, the Western Canadian bankers keep their dollars busily engaged in providing for the financial requirements of trade and commerce within their own territory.

71 Vide C. B. Piper, loc. cit., pp. 185-186. 
Occasionally it happens that the banks have not at their disposal the whole of the huge sum necessary to finance the crop movement from the farms to the head of the lakes. It is then necessary for the banks to seek outside help by borrowing credit from the Government or from some other source. If, for any reason, the banks did not make credit available in sufficient quantity to those who buy wheat from the farmers, the purchasing power of the buyers would be naturally restricted, the farmers would tend to sacrifice their grain for unduly low prices, and the whole machinery of the grain trade would be seriously affected. It is thus seen that the normal functioning of the banks is of the very highest importance both to the grain growers and the grain buyers.

When an elevator company buys grain in the country, it pays eash to the farmer, using money borrowed from the bank; and it then immediately re-sells the wheat at a slightly higher price on the Winnipeg Grain Exchange as a future, i. e., for delivery in some future month at Fort William or Port Arthur. This operation is known as hedging. The immediate re-selling of the grain as a future protects the elevator company against loss by a possible fall in the market during the weeks or months that the grain is en route to the head of the lakes, enables the company to make a definite small profit on each transaction, and, at the same time, protects the bank from which credit has been borrowed. The selling of cash grain as futures serves as a means of eliminating speculation from the business of the elevator companies; and one of the most important and beneficial functions of the Grain Exchange is that of providing the machinery by which such selling is accomplished. Were this machinery not always available, the banks could not afford to lend their money for moving the grain as cheaply as they do, and 
the grain growers in consequence would obtain less for their wheat.

\section{The Flour Mills of Western Canada}

The flour mills of western Canada, as elsewhere, are situated where power is cheap and shipping facilities are most favorable. These strategic points are to be found at Fort William on Lake Superior, at Keewatin and Kenora on the Lake of the Woods, at Winnipeg, and at various other localities on the trunk lines of railways. The mills at Keewatin and Kenora are driven directly by water power, whilst those at Fort William and Winnipeg are driven by electric power derived from waterfalls. It is interesting to note that the three mills at Medicine Hat obtain their power from natural gas which is used to drive electric motors.

In the provinces of Manitoba, Saskatchewan, Alberta, and British Columbia, there are 148 flour mills having a daily capacity of 36,000 barrels; and, in addition, there are nine mills having a daily capacity of 3,200 barrels, which produce rolled oats and oatmeal. ${ }^{72}$ By provinces the statistics for the flour mills are as follows:

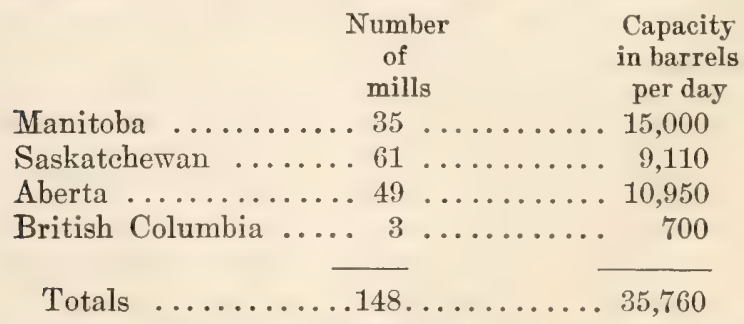

Fort William, Keewatin, and Kenora are situated in the Province of Ontario but to the west of the Great Lakes

72 As fixed by law, one barrel of flour contains 196 pounds standard weight of flour. Two bags make one barrel, and a bag of flour therefore contains 98 pounds. 
and in the Western Grain Inspection Division. The mills which they contain, although belonging to an eastern province, are therefore western for all practical purposes.

A considerable number of the mills of western Canada are known as Midget mills. The Midget mill is constructed by the manufacturer of a standard size. When a mill is ordered, the parts are shipped to the buyer and, upon arriving at their destination, are rapidly put together, so that the mill may be operated at once. On the other hand, western Canada also possesses some of the largest, the most modern, and the most highly efficient mills in the world. Among these may be mentioned the plants of the Lake of the Woods Milling Company at Keewatin, which consist of two units capable of grinding 9,000 barrels of flour every day. The Ogilvie Flour Mills Company Limited - the pioneer company - has plants at Fort William, Winnipeg, and Medicine Hat, which together have a capacity of 8,500 barrels daily. This company also grinds western wheat at Montreal where its mills have a combined capacity of 8,000 barrels per day. The Western Canada Flour Mills Company Limited has a very large mill at Winnipeg with a daily eapacity of 5,500 barrels; and, in addition, it has smaller mills at Brandon and Calgary. The Maple Leaf Milling Company Limited has mills at Kenora, Brandon, and Medicine Hat with a combined daily capacity of 5,000 barrels. The Maple Leaf Company also grinds western wheat at its great mill at Port Colborne on Lake Erie in Ontario, this mill having a daily capacity of 9,000 barrels. The milling system of all the great roller mills which have here been mentioned, is known as American as distinguished from the English system.

Fifty per cent. of the output of western Canadian flour mills is exported to other countries, Great Britain being 
by far the largest customer. The rest of the flour is distributed throughout Canada for domestic consumption.

The total number of flour mills in all Canada is 710 with a daily capacity of 125,000 barrels of flour, of which in the four provinces of western Canada, as we have seen, there are 148 mills with a daily capacity of 36,000 barrels. During the food crisis in the crop year 1917-18, Canada supplied to the Allies in the great war $10,000,000$ barrels of much needed flour in addition to her exports of wheat. $^{73}$

At the entry to the office of the Lake of the Woods Milling Company, at Winnipeg, stands a quern which was brought to western Canada from Russia by the Doukabors about twenty years ago. As one looks upon it for the first time, one straightway compares it in the mind's eye with the great modern roller mill which the Company owns at Keewatin. How curious and striking is the contrast! The quern consists of two stones set one on the top of the other in a solid wooden stand. The stand rests on four stout legs and its top is thereby raised about two and a half feet from the ground. The upper stone which is pivoted upon the lower one, is flat above and below, and is cylindrical in form. It measures fifteen inches in diameter, is about five inches thick, and weighs upwards of sixty pounds. In its center is a hole into which handfuls of wheat used to be put so that the grain might pass downwards between the stones. The upper stone was revolved by hand with the aid of a short handle; and, as a trial proved, a considerable amount of physical energy must have been expended by the man or woman who turned it. The flour produced by the grinding came out laterally between the stones and passed down a groove in

73 For the statistical information given above, I am indebted to the Northwestern Miller. 
the wooden stand into some receptacle provided to collect it. The quern is now naught but a relic of the past and reminds one of the fossils of extinct animals which add so much fascination to the pages of the great book of the geological record. Since the hey-day of the quern several centuries ago, the milling industry has been subjected to progressive evolution and, did not history tell us of its details, we should find it almost as difficult to realize that the modern roller mill has developed from the old hand-stone as it is to realize that the swallow and the seagull have sprung from a cold and slowly creeping reptile. In contrast with the quern, how complex and wonderful seems the great Lake of the Woods mill at Keewatin, with its mighty elevator for storing wheat, its great warehouse filled with bags and barrels for holding the mill's end-products, its loading and unloading facilities, its turbine for tapping the giant strength of the river, its power house, its driving belts, its appliances for cleaning and preparing the grain, and above all, in the mill proper, its automatic machinery which, ever humming at its work, seems to enjoy its task of reducing the grain into the finest flour. So continuously, so delicately, so gradually, and yet withal so irresistibly is the reduction process carried out, and so many are its stages, that one is involuntarily reminded of the reduction and assimilation of food that goes on in the digestive tract of one of the higher animals. As one observes the succession of corrugated chilled-iron rollers for breaking open the wheat berry, the gyrating boxes or plansifters for sifting the break flour, the dunst, the middlings, and the semolina from the broken wheat and bran, the purifiers in which the breath of the mill removes the fine branny particles from the middlings, the silk bolting cloth of finer and ever finer mesh for grading the middlings, the smooth rollers, pair 
after pair, for crushing the middlings into flour, the worm conveyers, the bran collector, the offal grader, the stockings for removing the mill dust, and much else; and, when one reflects that the mill works continuously night and day, week in and week out, with so little manual labor spent upon its guidance, and yet with thousands of barrels of flour turned out every day, one cannot help admiring the ingenuity of man and rejoicing at such evidence of his mastery over the forces of nature. Not small indeed is the debt of gratitude which Canada owes to the great inventors of the past who have made her present development possible.

\section{Recent Improvements in the Conditions of Farm Life}

The conditions of farm life on the prairie have been steadily improved in the last few years owing to the introduction of various conveniences. Farming implements, such as plows, binders, and threshing machines, have undergone progressive evolution, so that the actual work of tilling the fields, gathering the crops, and threshing the grain, has become much more scientific and efficient than it was. Light metal-frame wind-mills have been erected on many farms as a source of pover for pumping water but are now being largely replaced by engines burning liquid fuel.

The gasolene or kerosene engine has been a particularly welcome addition to the farm and is now much used to save both time and manual labor. ${ }^{74}$ Smaller engines are employed for pumping water, and for operating the milking machine (with which several cows may be milked at one and the same time), the cream-separator, the churn,

${ }^{74}$ Kerosene, on account of its cheapness and efficiency in producing power, is now becoming a popular substitute for gasolene. 
the washing machine, the grindstone, and the fanning mill for cleaning grain intended for seed. Larger engines are employed for chopping roots and grinding grain for feed, for cutting wood, and for running the threshing machine.

The tractor, which is essentially a gasolene or kerosene locomotive, is now beginning to replace the horse in the work of plowing and of transporting heavy loads of grain to the elevators, etc. It is also used, where it is available, instead of the stationary gasolene or kerosene engine, to drive the larger threshing machines.

One of the most recently perfected conveniences is the isolated farm lighting plant which has already been installed on many large farms. The gasolene or kerosene engine and the electric generator may be combined in one fixture or be separate so that the engine is movable. The electricity produced in the generator is usually conducted to storage batteries, and these can be sufficiently charged in a few hours to serve the lighting system for a week. The current may also be taken directly from the generator and be employed either for giving light or, through the medium of a motor, for driving the various machines in the home. The electric lighting system is used for illuminating not merely the farm house but also the barns, the stables, the yards, and even the chicken houses, with a consequent falling into disuse of the time-honored but troublesome coal-oil lamp and lantern, and a corresponding diminution in the risk of fire.

Sanitation has been improved by the proper installation of mangers, stalls, and floors in horse and cattle stables. Owing to this change, the work of tending livestock has become much more pleasant and healthful than it was. Many farms are now equipped with an aseptic tank and a running-water system which give conveniences 
in the lavatory and kitchen of the same nature as those commonly enjoyed in a city home.

Millions of trees supplied from the Dominion Arboretum at Indian Head and from other centers, have been planted on the farms where they act as wind-breaks, provide wood-lots for the supply of firewood and small timber, give relief to the unbroken sky line, and add a note of distinction and attractiveness to the home. Here, too, may be mentioned the phonograph. Before its introduction, in many an isolated farm house, the sound of musical instruments and the voice of song were rarely or never heard; but now, with the assistance of the phonograph, the spare hours may be pleasantly beguiled with reproductions of the best that the musical world can provide.

The telephone of which there is a web of wires in most rural communities, and the motor car which is now exceedingly popular with the farmer and his wife, have drawn the farms together and have done much to annihilate the great spaces of the prairie. In cases of childbirth or of sudden illness, it is now much more easy than it was to summon and obtain medical assistance. The motor car permits of increased social intercourse between the families of neighboring farms, and the telephone keeps the farmer in tonch with the world's markets. One of the amenities of life marle possible by the introduction of the telephone is the playing of interfarm chess matches during the long winter evenings.

It is probable that in the near future wireless telegraphy will be used to connect the pioneer's of outlying settlements, survey parties, and explorers with older communities, and that the aëroplane will find employment in hastening the transportation of rural mails, of postal packets, and possibly even of agriculturalists. The carriage of freight by dirigibles or other flying machines 
has not yet been placed on a commercial basis; but, should that happen in the near or distant future, it might well have a very important effect not only upon farm life but upon the whole course of the grain business.

\section{The Agrarian Movement}

For the purpose of advancing their social and economic interests, the farmers of the West have organized themselves into associations in each of the three Prairie Provinces. The movement began in 1901 at Indian Hear and spread rapidly, with the result that there are now in existence: in Manitoba, The Manitoba Grain Growers Association; in Saskatchewan, The Saskatchewen Grain Growers Association; and, in Alberta, The Lnited Farmers of Alberta. Each of these associations has its local units scattered throughout its own province. For the last few years, therefore, the farmers of the West have had an opportunity of realizing the power and the benefits that accrue from organization. The latest phase of this activity is the adoption of a political platform which may lead to legislation of great importance not only to all grain growers but to the whole of the Dominion of Canada.

To advance their business interests, the farmers of the ITest have organized two great trading companies in which there are already 65,000 shareholders. These companies are: United Grain Growers Limiter, and The Saskatchewan Co-operative Elevator Company. The former carries on a general grain business through its country elevators seattered throughout the three provinces and, by means of ears consigned by farmers, handles live-stock on commission, and supplies farmers with machinery and general commodities. The latter handles grain through its elevators or on consignment, but, as yet, has not en- 
tered the live-stock business and does not deal in machinery or supplies. The Saskatchewan Grain Growers Association, through its central office at Regina, has undertaken trading activities in farm implements and other farm needs.

Shortly after the Grain Growers Grain Company ${ }^{75}$ began its grain business in 1906, it was found that the organized farmers of the Prairie Provinces needed a publication that would be free to speak out frankly on questions in which the farmers were interested. The Grain Growers Guide was therefore established for this purpose; and it began its issues at Winnipeg in 1908 . It is the official organ of the associations in each of the three provinces, and now has a circulation of 51,000 copies per week - the largest circulation of any farm paper in the West.

The farmers' trading companies control over 600 country elevators and also have at their disposal immense storage space in terminal elevators at Fort William and Port Arthur. United Grain Growers Limited own a house at Port Arthur with a capacity of 600,000 bushels, and have also leased from the Canadian Pacific Railway Company at Fort William a terminal elevator that holds 2,500,000 bushels. The Saskatchewan Co-operative Elevator Company has a 2,500,000-bushel elevator at Port Arthur, so that the total storage capacity of the farmers'

75 The Grain Growers Grain Company was the first of the farmers' trading companies and was organized in 1906 without Government aid. It was interprovincial in character. In 1913, The Alberta Farmers Co-operative Elevator Company was organized for the province of Alberta with Government aid. In 1917, the Grain Growers Grain Company and the Alberta Farmers' Co-operative Elevator Company amalgamated their interests, so as to form United Grain Growers Limited. The Saskatchewan Co-operative Elevator Company was organized in 1911 on a strictly provincial basis and received Government assistance. 
terminal elevators at the water front of Lake Superior is 5,600,000 bushels. Before the war, The Grain Growers' Export Company, a subsidiary company of United Grain Growers Limited, was also doing an immense export business from New York. Two years ago, however, its full office equipment was turned over to the British Government for the benefit of the Allies in the war.

As bearing upon the progress and power of the farmers' companies, it is interesting to note that, following the big crop of 1915, these companies actually handled for the farmers close upon $100,000,000$ bushels of grain ; and also that, in the year ending August 31, 1918, the value of the machinery and supplies sold to farmers by the farmers' companies amounted to about $\$ 8,000,000$. 


\section{CHAPTER III}

\section{The Discovery and Introduction of Marquis W HEAT}

\section{Introduction}

Marquis Wheat is a household word in western Canada, for it is the chief variety of wheat grown in $\mathrm{Al}$ berta and Manitoba, while in Saskatchewan it forms about 90 per cent. of the crop. Moreover, its cultivation has increased the wealth of western Canada by many millions of dollars a year. It is therefore well worth while to inquire how Marquis wheat came into existence and to whom the credit is due for supplying it to the farmers in the first place.

The history of Marquis wheat is by no means so well known as it deserves to be, and various more or less erroneous ideas are current concerning it. In the interests of truth, therefore, as well as with a view to supplying information which should be a source of satisfaction to every patriotic Canadian, the writer here records the results of his own inquiry into the matter. The facts with regard to the origin of Marquis, about to be ccmmunicated, were obtained in part by the consultation of documents but, in the main, by interviewing Dr. Charles E. Saunders, who isolated Marquis more than a decade ago and whose modesty is only equaled by his skill and devotion as Dominion Cerealist.

\section{Dr. William Saunders and His Assistants}

Dr. William Saunders, the organizer and first Director of the Dominion Experimental Farms, conceived the idea 
of improving plants by breeding; and in this work he employed the services of several men, including his two sons, C. E. Saunders (now Dominion Cerealist) and A. P. Saunders. Before becoming Director of the Experimental Farms, Dr. William Saunders devoted himself to producing new and better fruits by cross-breeding. Special attention was paid to raspberries, currants, gooseberries, and grapes, and with these he achieved considerable success. One of his grapes, Emerald, obtained an award at the Indian and Colonial Exhibition in 1886; and even to-day two of his gooseberries, Pearl and Josselyn (his Red Jacket), are well known, and two of his black currants, Climax and Saunders, are considered excellent. After becoming Director in 1886 , Dr. Saunders continued his work on fruits with especial reference to hardy apples for the Canadian North-West. ${ }^{1}$ However, he also struck out in new directions. In particular, he focussed his attention upon wheat and began a long series of observations and experiments directed toward the improvement of the varieties then being grown in Canada. ${ }^{2}$

Red Fife became the standard variety of wheat in western Canada in the early eighties of the last century. It was not only very productive but possessed excellent milling and baking qualities, so that it was prized by

$1 \mathrm{Mr}$. W. T. Macoun, the Dominion Horticulturalist, is continuing the work of Dr. Saunders on hardy apples. Vide W. T. Macoun, The Apple in Canada, Its Cultivation and Improvement, Bulletin No. 86, Dominion of Canada Dept. of Agriculture, Division of Horticulture, Ottawa, 1917.

For a historical sketch of the work of Dr. Saunders in improving the currant, gooseberry, and raspberry, vide Bulletin No. 56 on "Bush Fruits" bv W. T. Macoun, 1907, pp. 62-64. Dr. Saunders" first crosses were made with gooseberries in 1868 .

2 Vide Experimental Farms Reports and Bulletins from 1888 onwards; also Dr. W. Saunders' Review of the Work with Wheat at the Experimental Farms in the Experimental Farms Reports for 1903, pp. 13-15. 
millèrs and bakers alike; and its first grade, Manitoba No. 1 Hard, fetched the highest price in the British market and became famous throughout the world. Unfortunately, however, in years with early frosts, Red Fife was often frozen in the fields; and, when this happened, the farmers cried out for a variety of wheat which would mature a few days earlier in the season. In the hope of meeting this demand, Dr. William Saunders imported a considerable number of varieties of wheat from many different countries, grew them alongside of Red Fife at the various Experimental Farms, and thus made a large number of comparative observations on their time of ripening and their yield. Some of these wheats were brought from the colder districts of northern Russia, verging on the Arctic circle, some from other countries in northern parts of Europe, others from different altitudes in the Himalaya Mountains of India - from 500 feet to as high as 11,000 feet which is about the limit for wheat growing in that range - and yet others from the United States of America, from Australia, and from Japan. Most of these wheats, such as those from the north-western parts of the United States and from Australia, proved to be as late in ripening as, or even later than, Red Fife, but the Russian and Indian wheats usually ripened earlier. However, some of the earlier sorts were inferior in their milling and baking qualities, and others gave such small crops that the growing of most of them had to be abandoned. For a time Dr. Saunders thought that Ladoga, a hard red Russian wheat which grows in latitude 60 near Lake Ladoga, north of Petrograd, and by latitude 600 miles north of Winnipeg, would solve the problem with which he was confronted, for it was found to ripen its grains over the whole Dominion about ten days earlier than Red Fife and also to give a good yield: $\Lambda$ fter being tested 


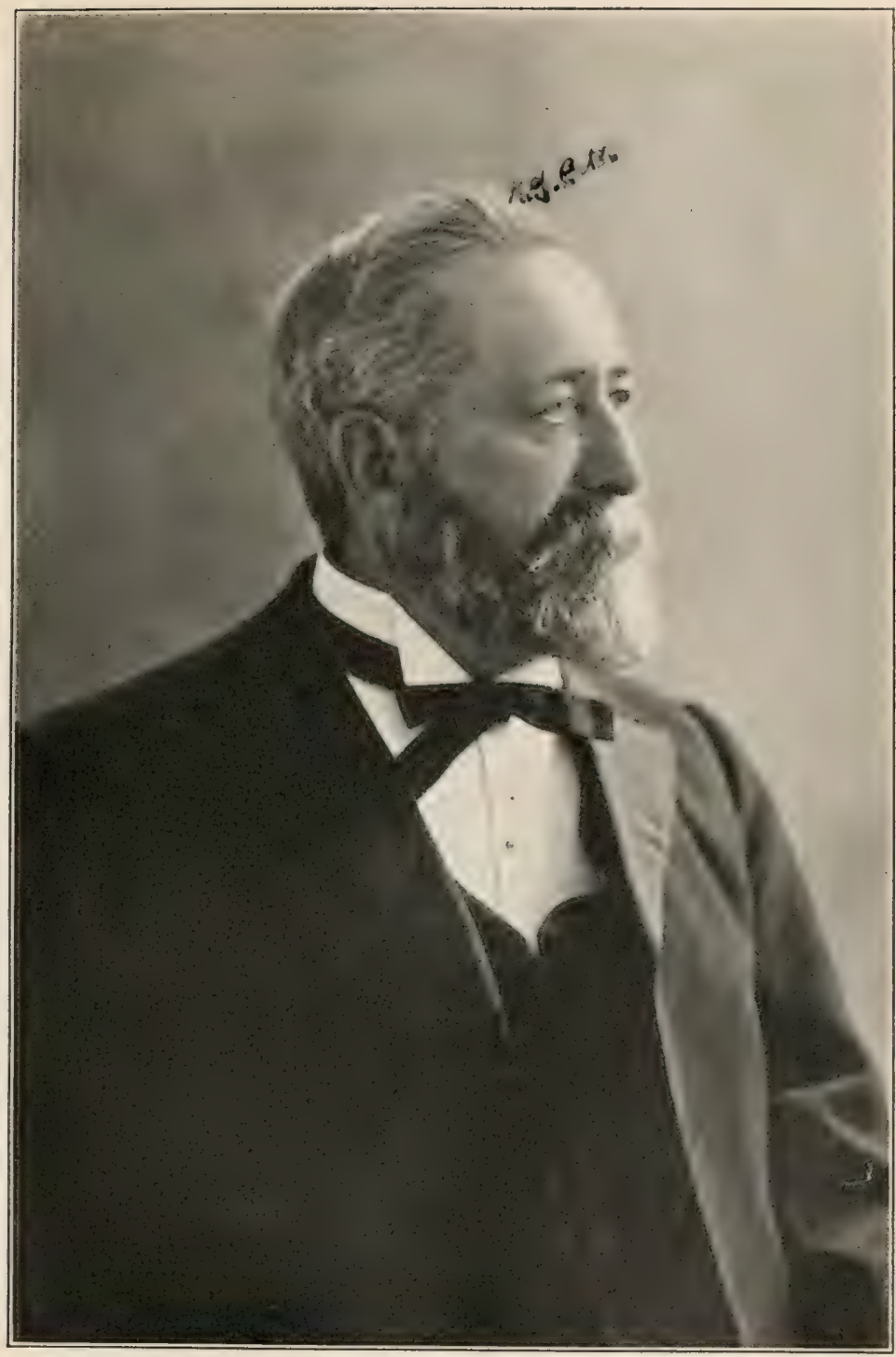

Fig. 21. The late Dr. William Saunders, the father of Dr. Charles Saunders, the first Director of the Dominion Experimental Farms, and the originator of Preston and Huron wheats. 

at the Experimental Farms, therefore, it was sent out to several hundreds of farmers in the North-West, a large number of whom reported favorably upon it. ${ }^{3}$ Thirty years ago, howerer, it was impossible to make satisfactory milling and baking tests, as is done now, with a few pounds of wheat only, and some hundreds of bushels were needed for this purpose. It was therefore necessary to wait several years before enough Ladoga could be procured to find out what qualities its flour really had. At length Messrs. MeLauchlin and Moore of the Royal Flour Mills, Toronto, agreed to make a thorough test if a car-load of Ladoga wheat could be supplied them. In 1892, therefore, the required car-load was obtained by Mr. Angus McKay of Indian Head from the Prince Albert district in Saskatchewan and conveyed to Toronto. Here the milling test was carried out by the Royal Flour Mills and the baking tests by several of the leading bakers of the city. The results of these tests were sadly disappointing, for Ladoga flour proved to be deficient in strength and produced bread which was very yellow in color and of a coarse texture. Thus the hope of replacing Red Fife by the earlier-ripening Ladoga, for export purposes, was completely shattered. ${ }^{4}$

Whilst making his vain search for a foreign earlyripening variety of wheat which should possess, in addition to marked earliness, the high productiveness and the excellent milling and baking qualities of Red Fife, Dr. William Saunders was also endeavoring to obtain the ideal wheat by combining the good qualities of two or

3 Ladoga Wheat; Part I by Wm. Saunders; Part II, Report on the Chemical Composition and Physical Characters of Ladoga, Red Fife and other varieties of wheat by F. T. Shutt, Bulletin No. 4, Central Experimental Farm, Ottawa, 1889.

4 William Saunders, Ladoga Wheat, Bulletin No. 18, Central Experimental Farm, Ottawa, 1893. 
more varieties. The method employed was that of crossbreeding, and the first crosses were made at the Central Experimental Farm at Ottawa on July 19, 1888. The pollen was taken from the flower of one kind of wheat and placed on the stigma of another kind from which the stamens had been removed; and the cross-bred kernel resulting was saved as seed for the next year. ${ }^{5}$ Many hundreds of crosses were made in this way, particularly between Red Fife or White Fife as one parent and an earlyripening wheat, such as Ladoga or one of the Indian wheats, as the other. Dr. William Saunders himself made many of these crosses at Ottawa but a large number of others were made by Dr. A. P. Saunders, Dr. C. E. Saunders, and Mr. W. T. Macoun, and a few by Mr. J. L. Mc.Murray, all of whom acted as his assistants. ${ }^{6}$ In 1892, Dr. A. P. Saunders was sent to the Experimental Farms at Brandon in Manitoba, at Indian Head in Saskatchewan, and at Agassiz in British Columbia for the purpose of making further crosses; ${ }^{7}$ and the cross-bred kernels which had been produced in the West, or their progeny, were subsequently transferred to Ottawa where the chief work of selection was carried out. As a result of these selections, a considerable number of wholly or partially purified new varieties of wheat were gradually isolated. By the year 1901, fifty-eight of these varieties which had undergone plot tests, had received names, and a statement

$5 \mathrm{WT}$. Saunders, How Varieties of Cross-Bred and Hybrid Grains Are Produced, Experimental Farms Reports for 1896, pp. 21-22. The illustrations were drawn by C. E. Saunders. For a minute description of the method of cross-pollination employed by C. E. Saunders twelve years later, vide Experimental Farms Reports for 1908 , p. 212.

6 ('f. Fxperimental Farms Reports: for 1896, p. 20; for 1897, pp. 16-17; for 1898 , p. 27 ; for 1900 , pp. 14-15; and for 1901, pp. 15-17.

7 Experimental Farms Report: for 1892, p. 234; for 1893, p. 336. 
had been issued for each as to its parentage, the year the cross was made, the place where the cross was made, and the name of the cross-breeder who made the cross. ${ }^{8}$ Some of these named varieties were distributed to the farmers of the West; and among the most noteworthy of them were: Preston and Stantey, each derived from a cross between Red Fife and Ladoga, and I uron and Percy, each derived from a cross between White Fife and Ladoga. The four crosses from which these four cross-bred wheats originated, were all made at the Central Experimental Farm at Ottawa, the first two by Dr. William Saunders himself and the last two by his son, Dr. A. P. Saunders. These four wheats all ripen a few days earlier than Red Fife but have various defects, especially in regard to their milling and baking qualities. This makes them undesirable for export from western Canada, and in consequence they have only been grown there on a relatively small scale; but a considerable amount of Preston, sometimes under other names, is still grown in the great central spring-wheat region of the United States. ${ }^{9}$

8 Experimental Farms Report: for 1896, p. 20; for 1897, pp. 16-17; for 1898 , p. 27 ; for 1900 , pp. 14-15; and for 1901, pp. 15-17.

9 The Preston originated by William Saunders was grown at the Minnesota Agricultural Station in 1895 as Ifinnesota No. 188 and was distributed under this number. The seed soon appeared for sale under various new names; and in a few years it could scarcely be found under its real name in the U. S. A. By the boards of trade of Minneapolis and Chicago, it was wrongly called Velvet Chaff, for it has a hairless chaff; and on the farms it was called Early Java, South Dakota Climax, Bearded Fife, Red Fife, Minnesota No. 18S, and Velvet Chaff. Under one or other of these names Preston has given good yields in central and eastern South Dakota and is rather widely grown there. It is found commonly also in eastern North Dakota and in parts of Minnesota. Selections of Preston have been given a series of Cereal Investigation numbers. These facts are stated by C. R. Ball in Varieties of Hard Spring Wheat, Farmers' Bulletin No. 680, U. S. Department of Agriculture, 1915, pp. 15-16. 
Crossing two kinds of wheat is a relatively simple operation, the technique of which it is not difficult to acquire. However, new varieties are not obtained in one generation only; for a cross-bred kernel, in succeeding generations, always gives rise to a large number of plant types which differ from one another in one or more characters - such as length and strength of straw, length, compactness, and uprightness of the heads, the color and hairiness of the chaff, presence or absence of awns, color, shape, size, and milling qualities of the grains, liability of the grains to shell, earliness in maturing, resistance to diseases, baking qualities of the flour, and so forth - and most careful selection through a series of years is necessary in order to isolate the best of its progeny. For this laborious work, Dr. William Saunders soon came to lack the necessary leisure. Owing to the great demands which the ever-growing general work of the Experimental Farms made upon his time and energies, the task of producing new wheats suited for the Canadian West had not proceeded very far before its prosecution came to a standstill. Dr. Saunders became so busy that, in the end, he was unable to exercise even a reasonable supervision of the wheat-breeding experiments. The result was that for several years no fresh experiments were undertaken, and almost all that happened was that the different kinds of grain were planted out upon the experimental plots and the little harvests duly gathered in. In this way various strains of wheat were kept in existence. At length, in 1903, Dr. Charles E. Saunders was appointed by the Government to take up the work of wheat-breeding; and he thus inherited the whole mass of material which had been brought together at the Central Experimental Farm. Dr. William Saunders, after a long and faithful service to the Dominion, retired in 1911 and passed away in his 
home at London, Ontario, on September 13, 1914, at the ripe old age of 78 . The most important of all the lines of endeavor which he initiated at Ottawa, undoubtedly, was the raising of new cereals; and it is its highly successful continuation by his third son Charles that we shall now attempt to follow.

\section{The Selection of Marquis by Dr. Charles E. Saunders}

Dr. Charles E. Saunders, on becoming the Cerealist for the Dominion of Canada, took up his quarters at the Central Experimental Farm at Ottawa and there carefully re-selected all the more or less mixed wheats which came into his hands. The result of this work was that in 1904 he discovered Marquis Wheat. By reference to the experimental records, proof was obtained that this particular strain had been produced from one of the crossings made in 1892 by his brother, Dr. A. P. Saunders, during the period when Dr. William Saunders and his two sons were working together. ${ }^{10}$ The male parent of the cross was Red Fife and the female an early ripening Indian wheat known as Hard Red Calcutta. It is to be noted, however, that Hard Red Calcutta is a trade expression, not for one particular variety of wheat but for a mixture of several varieties. There must, therefore, alwavs be a certain amount of doubt as to the exact type which served as

${ }_{10}$ Dr. Arthur Percy Saunders took his degree of Ph. D. at Johns Hopkins University, and is now Professor of Chemistry at Hamilton College, Clinton, New York State, U. S. A. His father needed some one with trained fingers to make some cereal crosses, and Dr. A. P. Saunders therefore undertook this work during one or two of his summer vacations. Thus his connection with agriculture in the larger sense of the term was of a very temporary nature. However, the influence of his early years spent at the Experimental Farm remains with him yet; for, although by profession a chemist, he is also an enthusiastic amateur florist and a breeder of peonies, etc. 
the female parent when the cross was made. The result of the cross, in a few generations, was a mixture of types including Marquis. Marquis, therefore, remained mixed with other sorts of wheat until it was discovered in 1904 by Dr. Saunders, in the course of his systematic work of re-selection of all the mixed wheats which previously had been produced by cross-breeding at Ottawa. ${ }^{11}$

The work of re-selecting the cross-bred varieties of wheat which resulted in the discovery of Marquis was no mean task; for, altogether, there were nearly one hundred of these varieties, and each variety (whether recorded under a name or under a number) contained several strains. The strains within a single variety often presented radical

11 Cf. C. E. Saunders, Report of the Dominion Cerealist for the year 1911-1912 in the Annual Report on Experimental Farms, Ottawa, 1913, pp. 118-119; also, by the same author: Marquis Wheat, C'ensus and Statistics Monthly, Ottawa, 1911, p. 332. Dr. Saunders once wrote a brief article on Marquis for the Saskatchewan Phoenix; but this I have not seen.

Dr. Saunders, in reference to the cross from which Marquis originated, says: "The cross was made on one of the branch experimental farms and the cross-bred seeds, or their progeny, were subsequently transferred to Ottawa. Here some selection was done. but the work was not carried far enough to separate out simple fixed types. It was therefore a mixture, lacking in uniformity, which came into the possession of the writer when he took charge of the Cereal Division. By a careful study of individual plants selected from the plot, and especially by applying the chewing test to ascertain the gluten strength and probable bread-making vaiue, radical differenees in quality were found, and a few of the most promising plants were used as a foundation of the new strains. These strains were propagated (each separately) for some years until they had been sufficiently studied to ascertain which was the best. The best strain was named Marquis." Cereal Breeding in the Dominion Experimental Farms during the Past Decade, Transactions of the Royal Society of Canada, Third Series, Vol. VII, Section IV, 1913, p. 152. The branch farms which Dr. A. P. Saunders visited in 1892 were Brandon, Indian Head, and Agassiz. It is not certain at which of these farms the cross was made, but Dr. Charles Saunders thinks it was probably Agassiz. 


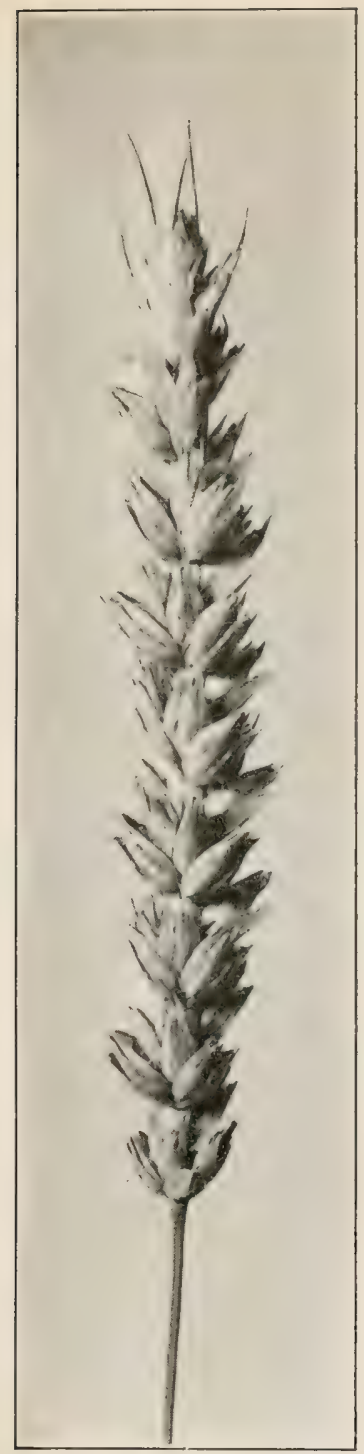

Fig. 22. A head of Narquis Wheat. Natural size. 


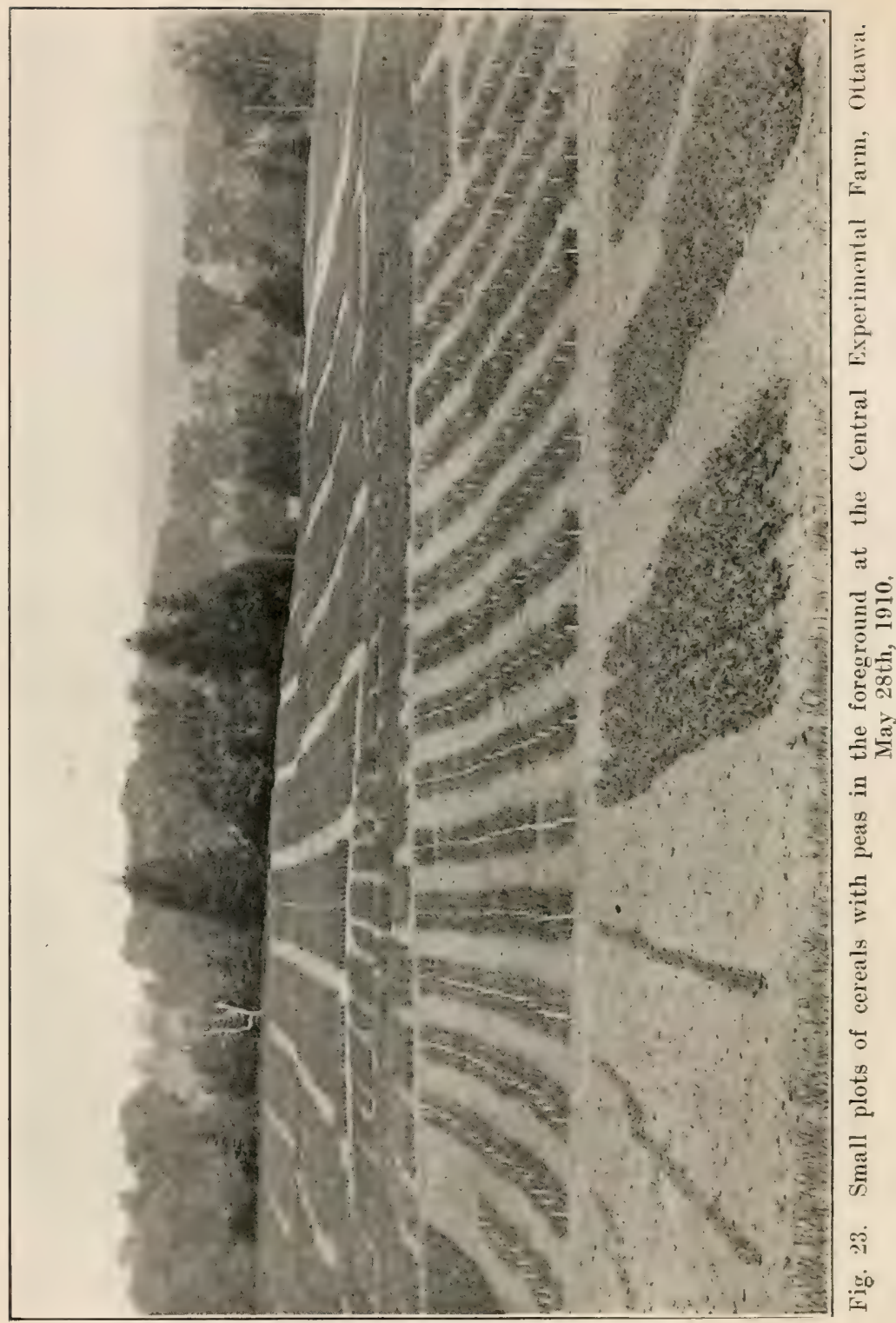


differences. Dr. Saunders worked steadily through all that material, studying head after head and selecting out as many different and promising ones as he could find. Each selected strain was then propagated in pure condition either from a single head or from two or more heads of a single plant. In subsequent years, those strains which proved unsatisfactory were rejected and destroyed, with the result that to-day only a small fraction of the strains originally selected remain in existence; but this is as it should be, for good experimental work in plant breeding, by its very nature, alwavs involves an extremely high percentage of failures. In addition to selecting the best strains from the cross-bred varieties, Dr. Saunders also reselected a considerable number of commercial wheats. All this work which was carried out systematically year after year in the faith that something of importance would result from it, demanded much patience, care, and good judgment. But the reward was great; for, from among the hundreds of strains investigated for their various qualities, Marquis finally emerged; and as in successive years it proved its excellence, first in plot tests, then in fields upon isolated farms, and finally upon rast stretches of the sea-wide prairie-land in both Canada and the Tnited States, Dr. Saunders was giren the satisfaction of realizing that his bright dream of one day helping the farmers of the Golden West had at last come true.

At first there were only a few grains of the precious Marquis, all obtained from a single head picked by Dr. Charles E. Saunders in the summer of 1903 ; but how great were their potentialities! These grains were planted out in the spring of 1904 in a tiny plot in the experimental garden. Soon they began to sprout, and at length there was a small patch of green containing only twelve plants in all. In August the little harvest was 
reaped. The yield was much less than a single pound of grain; and the first crop of the wheat that was destined within a dozen years to overtax the mightiest elevators in the land, was stored away in the winter of 1904-05 in a paper packet no larger than an envelope. But just as a few sparks are endowed with tremendous destructive possibilities, so that, by starting a conflagration, they may bring red ruin to an ancient city, reducing its treasures to blackened heaps; so, in happy contrast therewith, the little collection of grains in the Marquis packet embodied vast constructive possibilities which, having been fortunately realized with the passage of time, have been a potent factor in the uprearing of many a snug farmhouse and many a stately civic building. In very deea, that first handful of Marquis grains has brought naught but increased prosperity in its wake and by its influence has made farming on the broad prairie-land a more attractive industry.

\section{The New Wheat is Named}

Dr. Saunders christened his new wheat Marquis for the simple purpose of distinguishing it from other wheats of which he already had many kinds in his laboratory; and up to the present even the most extreme socialist has never objected to this title.

\section{The Qualities of Marquis are Investigated}

Dr. Saunders then set to work to investigate the qualities of Marquis. In the first place he observed that it belonged to the early group of wheats, i. e., that it ripened its grains in summer earlier than most of the common wheats of Canada. Earliness, of course, is a very important quality, for the sooner the grain ripens, the less 
danger is there of its being injured or destroyed by Rust or early frosts. But another good quality made its appearance as the study of the annual harvests continued, namely, yield. Marquis was found to give an excellent yield, this being in part due to the marked plumpness of the grains. Evidently, therefore, the new wheat behaved well in the field. But besides good field qualities, it is necessary for a successful wheat to have good baking and milling qualities. It was essential, therefore, to investigate these latter also. In the winter of 1903-04, Dr. Saunders did not possess a well-equipped laboratory and had at his disposal neither a mill to grind wheat into flour nor an oven to bake bread. But, at that time, even if mills and ovens had been available, it would have been impossible to use them for testing the milling and baking qualities of Marquis, owing to the fact that the number of grains with which the tests might be made was limited to the few that could be spared from the single head of wheat selected in 1903 for seed purposes. The clew to the milling and baking qualities of Marquis was therefore obtained by chewing the grains. It was found that on taking a few grains of the Marquis wheat and chewing them as if one were chewing chewing-gum, an elastic mass was obtained which was of good color, i. e., not too yellow but pale cream or whitish. The color is of importance, for the lighter it is, the lighter, and therefore more attractive-looking, will be the flour produced from the wheat in a mill. The light color of the elastic mass, when taken from the mouth, was therefore all in favor of the Marquis wheat so far as the miller is concerned. The elasticity of the mass gave an indication of the way the wheat would behave as to baking qualities. The elasticity of the mass produced by chewing a few grains of wheat of different varieties varies greatly; but, as a rule, the more elastic 
or rubber-like the mass, the bigger the loaf that can be made from the flour, or, in other words, the better the baking qualities. The elasticity is due to the quality of the gluten, a mixture of complex proteins which are present in the grains along with the starch. Dr. Saunders found that a few grains of the Marquis wheat, when chewed in the mouth, produced an elastic mass which was rubberlike in a high degree, and therefore concluded that Marquis wheat had an excellent quality of gluten and would make large and palatable loaves. Thus, then, by a careful series of abservations extending over three years, Dr. Saunders discovered that Marquis wheat behaved well in plot tests in respect to the early ripening of its grains and in having a good yield, and that it possessed milling and baking qualities of the most desirable kind.

Dr. Saunders propagated his new wheat from 1904 to 1906 , so that it gradually increased in quantity. The few ounces of grain collected in August, 1904, in successive harvests increased in amount in geometrical progression, and, by the autumn of 1906 , about two-thirds of a bushel were available. The chewing tests for milling and baking qualities were carried out systematically for three years, in 1904, 1905, and 1906. Toward the close of this period, a small flour mill, a fermenting-cupboard designed by Dr. Saunders himself, and an oven, were set up in the cereal laboratory; and with this apparatus many experiments were made with different wheats with a view to obtaining an accurate knowledge of the best methods of carrying out milling and baking tests. By the year 1906, the crop of Marquis wheat had at last increased sufficiently to permit of some of it being made into flour by grinding the grains in the mill, and of loaves being made by baking in the oven. Rigorous tests for the milling and baking qualities of Marquis, made with the new apparatus in the winter 


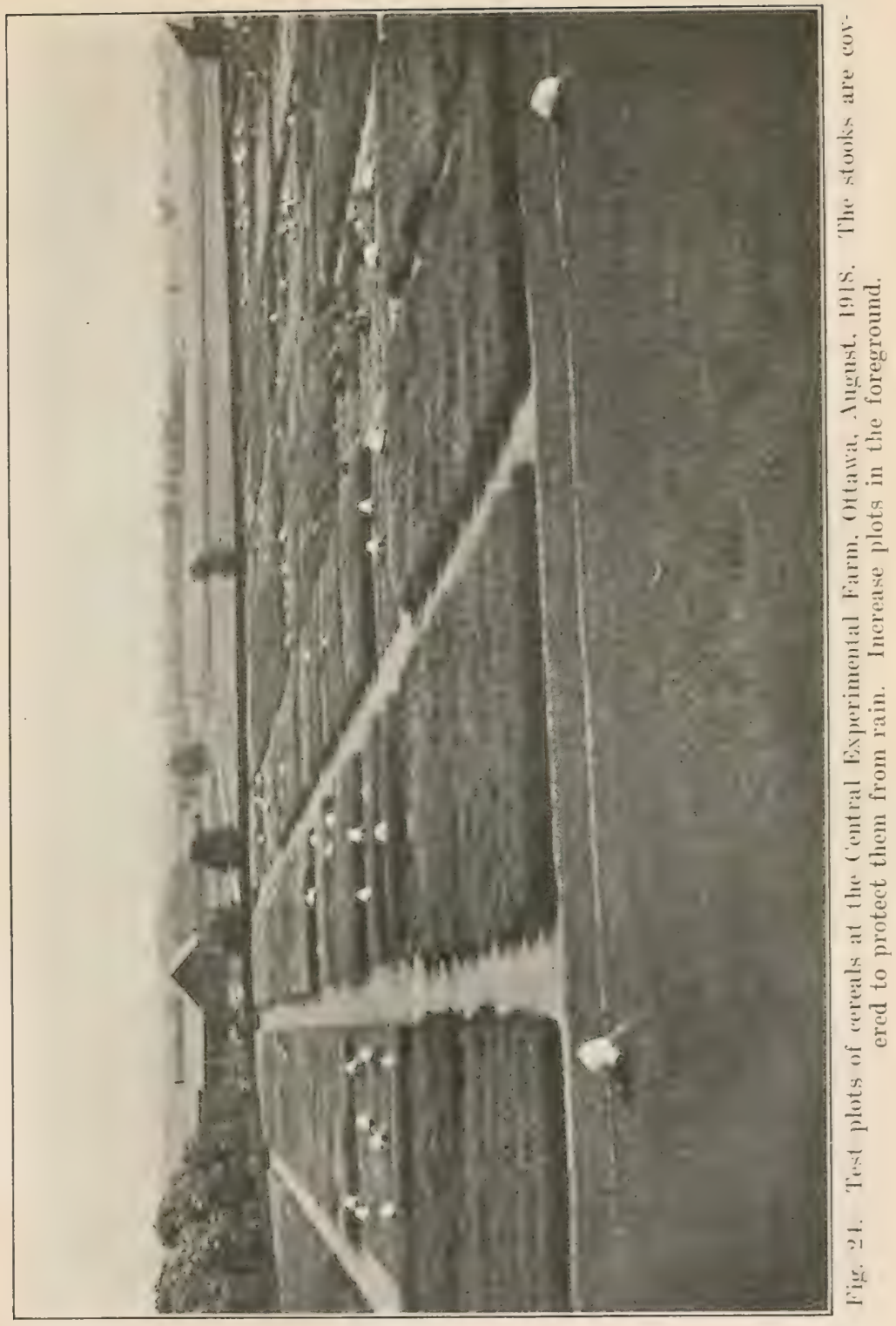




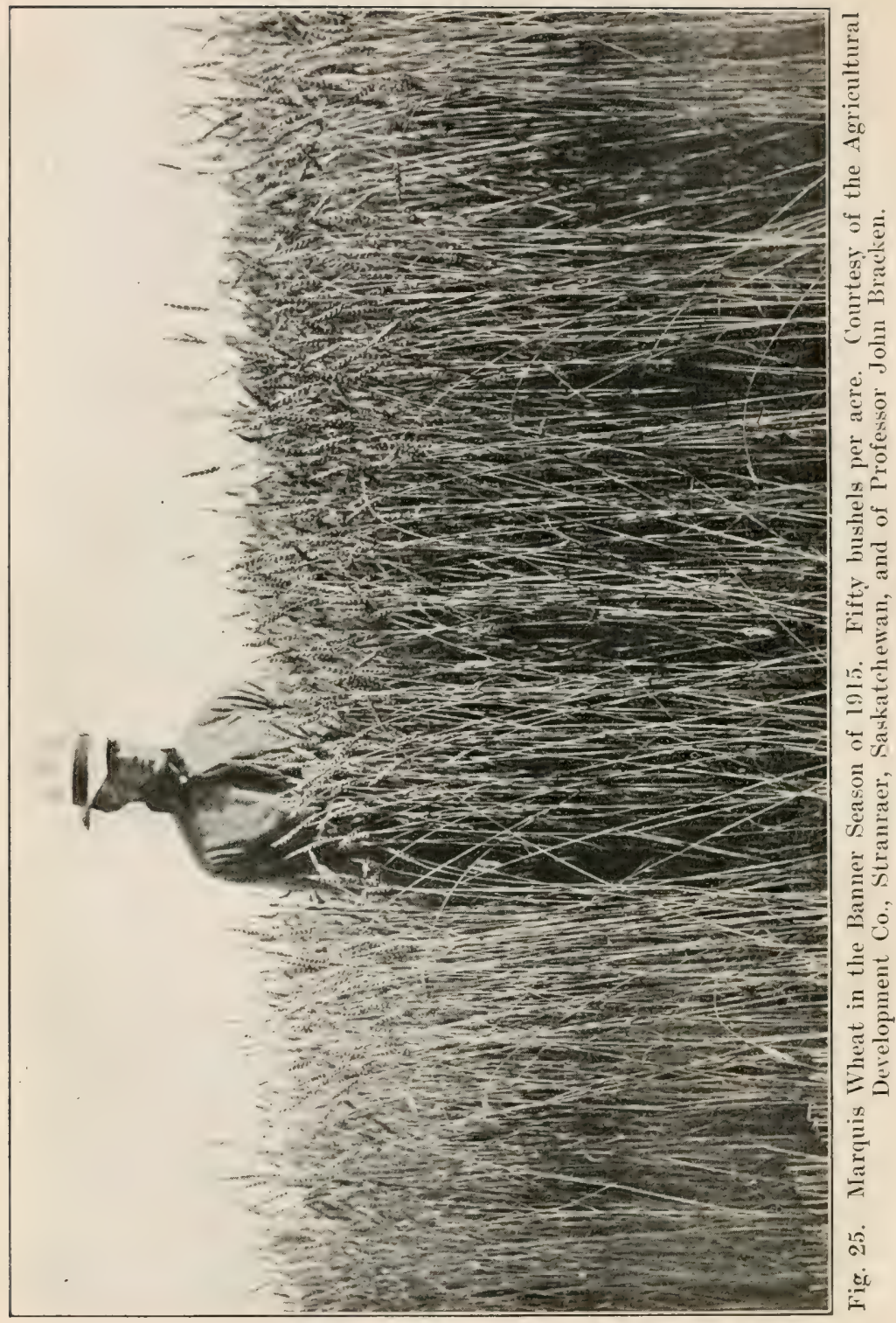


of $1906-0 \tau$ and the following years, fully confirmed the original estimates which had been arrived at by using the teeth as grindstones and the mouth as a substitute for an oven.

\section{The Introduction of Marquis into Western Canada}

In the spring of 1907 , all the seed that could be spared, about $23 \mathrm{lbs}$., was sent from Ottawa to the Indian Head Experimental Farm in Saskatchewan, and there the grain was sown on two plots, one of one-fortieth of an acre and the other of one-fifth of an acre. In 1908, further tests were made not only at Indian Head but also at the Brandon Experimental Farm in Manitoba. The seasons of 1907 and 1908 were somewhat unfavorable for wheat in general, and, under these conditions, Marquis did astonishingly well, far better than Red Fife which had always been regarded as the best wheat and with which it was compared in the experimental plots. In the spring of 1909 the distribution of Marquis to the public began. Four hundred samples were sent out and the farmers who received them sowed the new wheat in many scattered places in western Canada. Marquis thus spread from Saskatchewan to Manitoba on the east and Alberta on the west. But this is not all, for it disregarded the international boundary line and peacefully penetrated into the United States, where it now covers vast areas, more especially in North Dakota, South Dakota and Minnesota. Furthermore, it is now much grown in eastern Canada, especially in Ontario and Quebec; and it has found its way into the Kamloops district of British Columbia. In the Maritime Provinces, however, it does not usually do so well. Its fame has attracted universal attention, and it is now being tested in almost every wheat-growing country in the world. Recently it was greatly in demand 
for seed purposes in France but could not be shipped in the quantity required.

Since the spring of 1909 when farmers began to sow Marquis for the first time, the growing of this wheat in Canada has spread enormously, and Marquis is now by far the chief wheat grown in the West. Practical experience with Marquis by tens of thousands of farmers on millions of acres has completely justified the original estimate of the wheat made by Dr. Saunders in the quiet of his laboratory. The introduction of Marquis wheat is one of the greatest practical triumphs that Canada has ever had, one that is perennially fruitful, not impoverishing but ever increasing the wealth of our country and making it a better land to live in. But this is not all, for Marquis extends its blessings far beyond the bounds of this country, not merely to the United States of America where it is also grown on a large scale, but to the Old World. Especially in Europe, to which it is borne by a great fleet of ships across the broad Atlantic, it adds to the quantity and improves the quality of the daily bread of millions of toilers who have never heard its name.

\section{The Introduction of Marquis into the United States of America}

The invasion of the United States of America by Marquis was rapidly accomplished, and took place in the following manner. After Marquis had been grown in the Prairie Provinces for a year or two, from 1909 onwards, farmers in North Dakota, South Dakota, Minnesota, and neighboring States, soon learned the news of its wonderful success from their Canadian friends. The result was that individual farmers in these States imported a certain amount of the new wheat for seed purposes. The favorable harvests which they obtained, attracted the at- 
tention of other farmers who also became anxious to give the new wheat a trial. To meet this demand, several car-loads of additional seed were imported by various seed firms in North Dakota in 1912. When Marquis began to arrive at the big flour mills of Minneapolis, the millers immediately recognized its fine milling and baking qualities; and they became enthusiastic advocates of its introduction into the Northwestern States. For example, the Russell, Miller Milling Company of Minneapolis, in the fall of 1913, made arrangements with the Angus McKay Farm Seed Company of Indian Head for the importation of nearly 100,000 bushels of Marquis from the Indian Head and Regina regions; and they supplied this seed to the farmers of North Dakota, Minnesota, etc., at cost. In order to make certain that this large amount of seed should be of first-class quality, the Russell, Miller Milling Company communicated with Professor H. L. Bolley, the Seed Commissioner for North Dakota, and requested him to inspect the fields from which the seed was to come. Professor Bolley, who had long been convinced of the importance of bringing into the United States seedwheat of high quality and who had perceived the good qualities of Marquis when grown on his experimental plots at Fargo, gladly undertook the mission; and the 100,000 bushels of Marquis duly arrived at its destination in excellent condition. ${ }^{12}$ A further 37,000 bushels were im-

12 The above facts were obtained by personal inquiry from Professor H. L. Bolley at Fargo, and from Mr. H. S. Helm of the Russell, Miller Milling Co., at Minneapolis. Mr. D. G. Mackay, of the Angus Mackay Farm Seed Co, gave the following additional information. The first two bushels exported by the Angus Mackay Farm Seed Co. were sent to the Northrup, King Co., of Minneapolis in 1910. This Company sent the two bushels to a farmer who lived near Grand Forks, N. D., in the Red River Valley; and the farmer contracted to increase it in amount for the Company. By the autumn of 1912, the crop had already become large and it was shipped as a car lot to the Russell, Miller Milling Co., at Minneapolis. 
ported for seed purposes and supplied to the farmers at cost by the Andrews Grain Company, also of Minneapolis. ${ }^{13}$ Other firms made similar importations on a smaller scale, so that, altogether, about 200,000 bushels of Marquis were brought across the Line and made available for seed in the spring of 1913 . In 1914 still more Canadian Marquis was brought in. Most of the imported seed was sold in Minnesota, North Dakota, and Montana, and small quantities in Iowa, Nebraska, South Dakota, and Washington. The importations for 1913 and 1914, together with the seed grown at home in 1913 , sufficed to sow about half a million acres in 1914. The total crop of Marquis in the United States, in the fall of 1914, was probably about 7,000,000 bushels and of this $6,360,000$ bushels were produced in Minnesota and the two Dakotas. ${ }^{14}$ This crop gave a large supply of home-grown seed and in consequence importations of further seed from Canada practically ceased. ${ }^{15}$

This firm's analyst immediately recognized the high gluten contents of the new wheat with the result that the Russell, Miller Milling Co. made further enquiries about Marquis and initiated their campaign for its introduction into the Northwestern States.

13 From the records of the Andrews Grain Company. The information was kindly supplied to me by Mr. Godfrey at an interview in the office of the firm.

14 C. R. Ball and J. A. Clark, Experiments with Marquis Wheat, Bulletin No. 400, Bureau of Plant Industry, U. S. Department of Agriculture, Oct., 1916, p. 4.

15 The following are the firms which purchased Marquis seed from the Angus McKay Farm Seed Co., or through it, during the first distribution of the seed in the United States, and the number of bushels of seed which each bought:

$$
\text { Firms Locality Bushels }
$$

Russell, Miller Milling Co.......Minneapolis .........111,552

Andrews Grain Co............. Minneapolis ........ 40,620

Northrup Grain Co..................... 11,000

D. B. Shaw............... Tower City, N. D. ..... 6,400

Harvey Milling Co............Harvey, N. D. ....... 2,500

Crookston Milling Co.......... Crookston, Minn. ...... 2,500 


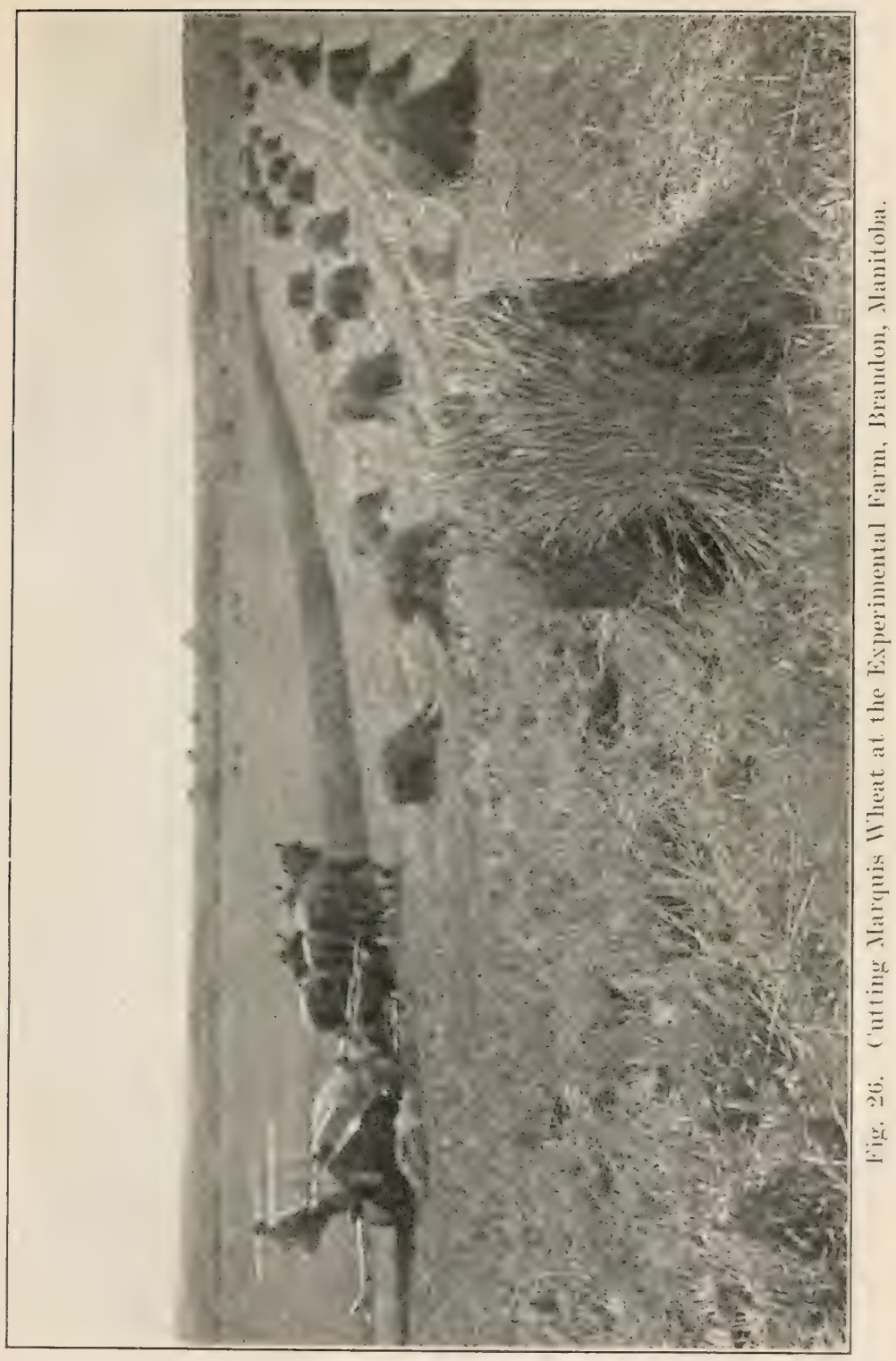




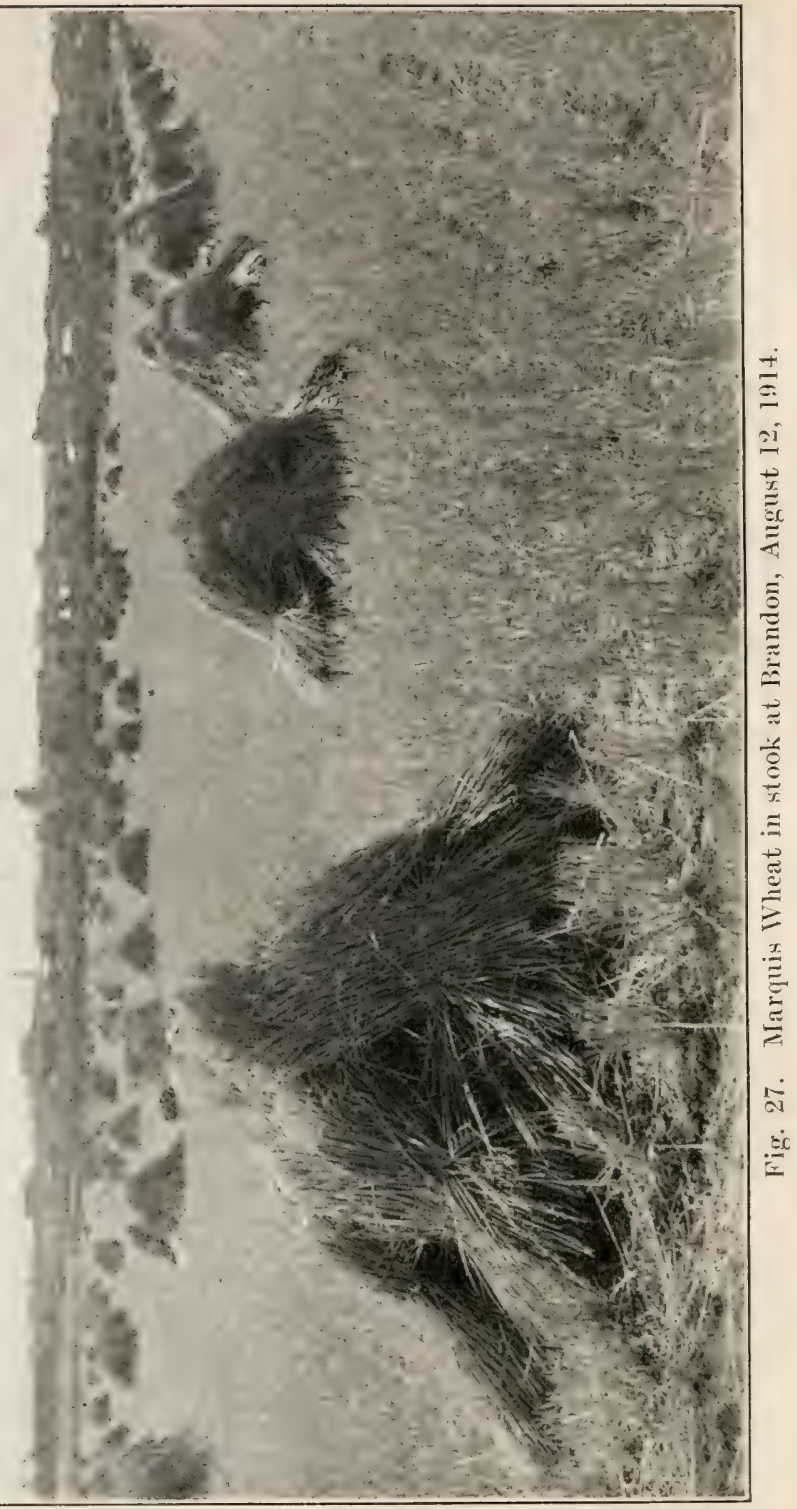


The result of importing and growing the seed of Marquis on a large scale was that this wheat made very rapid strides in the Northwestern States. Thus in North Dakota, by 1915 - a year when this State is reported to have produced $152,000,000$ bushels of wheat ${ }^{16}$ - a very large percentage of the crop, at least 25 per cent., consisted of Marquis; ${ }^{17}$ and now (1918) Marquis is the chief bread-wheat grown there, forming perhaps 75 per cent. of the whole crop. ${ }^{18}$

In North Dakota, owing to general farming operations, particularly the uninterrupted wheat culture on the same land year after year, the wheat in that State, previously to the introduction of Marquis, had become very generally mixed through additions made by volunteer wheats, etc. One of the evil consequences of this was that the ripening of the grain in the fields was irregular: the heads did not all mature at the same time and farmers found themselves in difficulty in deciding the time of cutting.

\section{Firms}

Loeality

Bushels

W. J. Jennison Co.............Minneapolis ......... 2,500

Baldwin Flour Mills...........Moorhead, Minn. ...... 2,000

McGill and Co..............Fargo, N. D. ........ 1,100

L. L. May and Co............St. Paul, Minn........ 1,000

Hanson and Barson..........Thief River Falls ...... 1,000

Total ..............182,172

The direct importers of a large portion of these lots of wheat was the O. J. Barnes Co., of Grand Forks, N. D.; and this firm therefore played an important part in introducing Marquis into the United States. Information supplied by the Angus Mackay Farm Seed Co.

16 Year Book of the U. S. Department of Agriculture for 1915, p. 422.

17 This estimate is lower than that made for me by Professor Bolley of the North Dakota Agricultural College and by Mr. H. S. Helm of the Russell, Miller Milling Co., but is in accord with the Table given further within this Section.

18 Estimate made by Professor H. T. Bolley of the North Dakota Agricultural College. 
And when the crop was harvested and sent to the mills, analysis showed that samples of what was nominally a single kind of wheat, such as Bluestem, contained all sorts of kernels, and were very unequal with respect to gluten contents. The want of uniformity in the crops of Preston and Bluestem which were once the principal wheats grown in North Dakota, was one of the chief business difficulties with which millers had to contend. Now Marquis, in 1913, was a fresh stock of wheat of uniform variety. It came to North Dakota just when the need of more uniform seed was most felt; and by replacing mixed wheats, apart from its good qualities of high yield, earliness, etc., it proved a great boon to farmers and millers alike and gave a new impetus to wheat culture.

In Minnesota, Marquis constitutes more than one-half and approaching three-quarters of the crop of spring wheat. ${ }^{19}$ Of the acreage in this rich State devoted to wheat this year, 1918, only 80,000 acres (chiefly in the extreme south) were sown with winter wheat, whereas about $4,000,000$ acres were sown with spring wheat. ${ }^{20}$ Now if we take one-half of this $4,000,000$, namely 2,000,000 acres, as having been sown with Marquis; and, further, if we assume that the average number of bushels of wheat per acre will be the same as it was for springt wheat in 1917 , namely $17.5 ;{ }^{21}$ then the yield of Marquis in Minnesota this year will be approximately 35,000,000 bushels. If, however, we assume, as seems almost certain, that at least 65 per cent. of the total crop will be Marquis, and that the total crop of spring wheat in Minnesota this year will be as esiimated on September 1, 19 Facts supplied by Professor Andrew Boss of the Agronomy Department of the University of Minnesota.

20 Ibid.

21 Year Book of the United States Department of Agriculture for 1917 , p. 617. 
1918, namely $72,417,000$ bushels, ${ }^{22}$ then to this crop Marquis will contribute approximately $47,000,000$ bushels. These estimates are sufficient to indicate to how great an extent Marquis must have replaced other grains such as Preston and Bluestem in Minnesota in the short period of five years which began in 1913 when it was first introduced from Canada on a large scale. But the end is not yet; for Marquis is becoming more and more favored

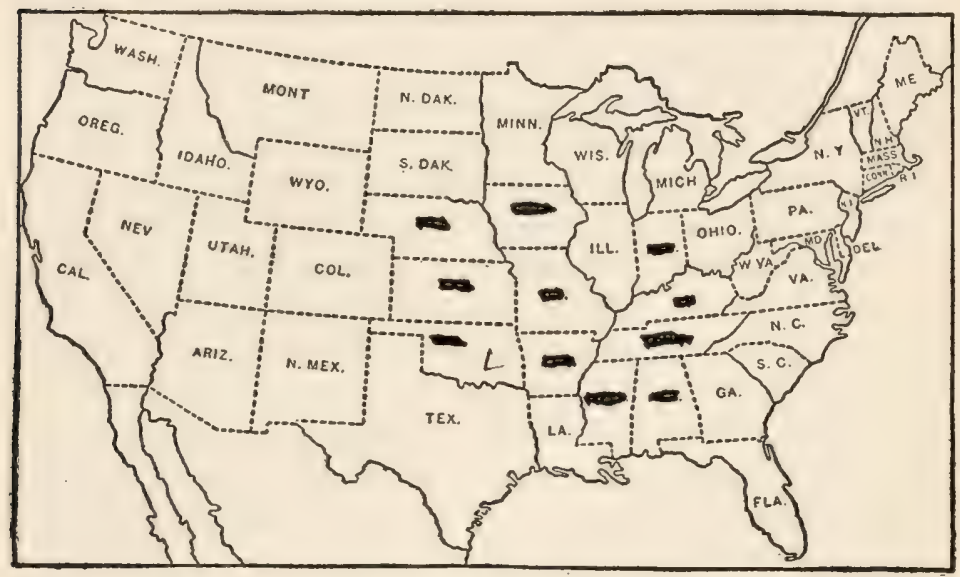

Fig. 28. Reference map for the United States.

by the farmers owing to its excellent yield, its plump, heavy, rich red-colored, highly uniform grains, its earliness, and its value to millers, and it appears destined in the very near future still further to strengthen its position as the dominant spring wheat of Minnesota.

One of the maps in the excellent Geography of the World's Agriculture, recently published at Washington, shows the distribution of spring wheat in the United 22 Monthly Crop Report, October, 1918, Bureau of Crop Estimates, Washington. 
States. $^{23}$ A single black dot, in any locality, indicates a crop from 5,000 acres. A glance at the map shows that the dots are most densely aggregated in North Dakota, South Dakota, and Minnesota ; and thus, by a pictorial setting forth of statistical data, one at once becomes convinced that these three States are the chicf of those that grow spring wheat. A further study of the map reveals the fact that spring wheat is also largely grown in Montana as well as in a belt of States surrounding those already named, and in scattered districts elsewhere. Now Marquis is a spring wheat, and on this account its distribution is of necessity confined to the spring-wheat States where of course it has to compete with other spring wheats of which the chief are Velvet Chaff (Preston), Fife (also called Red Fife, Scotch Fife, etc.), and Bluestem. The first four States in order of importance, so far as Marquis is concerned, are: North Dakota. Minnesota, South Dakota, and Montana; but Marquis is also grown, although in much smaller quantities: to the south, in western Nebraska; to the west, at certain altitudes in Colorado, in Wroming, at altitudes between 800 and 4,500 feet in Idaho, and in the State of Washington; and to the east, in Iowa, Wisconsin, Illinois, Indiana, Ohio, and Tew York. $^{24}$ In the spring of this year, 1918, in order to increase the supply of bread for the Allies in the Great War, the farmers of the six last-mentioned easterly States considerably extended their spring-wheat area, so that it became much greater than it had been in 1917. To provide seed for the additional land. Marquis was made available

23 Finch and Baker, Geography of the World's Agriculture, U. S. Department of Agriculture, Government Printing Office, Washington, 1917.

24 For this geographical information I am indebted to Mr. C. R. Ball of Washington, Dr. E. K. Stakman of St. Paul, and to Dr. Charles E. Saunders. 
in large quautities at Minneapolis, Buffalo, and at other places, so that it is probable that this year one-half the spring wheat in the six States under discussion has consisted of this variety. ${ }^{25}$

Marquis was first grown in the Pacific Northwest in considerable quantities during the season 191t. The increase was sold for seed, and by 1916 Marquis began to be shipped away. Some of it found its way to the markets of the Central States; and this led Professor C. H. Bailey to make a careful investigation of its qualities. He visited the so-called Inland Empire and found that the greater part of the Marquis wheat was being raised: in the Palouse district near Pullman (Washington) and Moscow (Idaho), in the Itez Perce district, particularly around Genesee and Lewiston (Idaho), and on the Camas Prairie between Reubens and Grangeville (Idaho). Professor Bailey collected samples of the wheat in all these distriets, tested them in his laboratory at the University of Minnesota, and came to the conclusion that the soft red and white wheats of the Inland Empire districts, such as Jones Winter Fife, Little Club, Red Russian, and Fortyfold, are generally inferior in baking qualities to MLarquis and Turkey wheat grown in the same localities. ${ }^{26}$

To what extent, in the end, IIarquis will establish itself in the Pacific Northwest, is as yet uncertain. It appears to be particularly well adapted to the higher altitudes of the Camas Prairie, since it matures there sufficiently early to escape the frost of late summer. ${ }^{27}$ Moreover, as we have seen, Pacific Northwest Marquis has come off with

25 From information sent in a letter by Mr. C. R. Ball, of the Office of Cereal Investigations, Washington.

26 C. H. Bailey, The Quality of Western-grown Spring Wheat, Journal of the American Society of Agronomy, Vol. 9, 1917, pp. $155-161$.

27 C. H. Bailey, loc. cit., p. 156. 
flying colors in the baking tests; but there is another fact of importance to consider, namely, yield. Messrs. Ball and Clark have come to the conclusion that while in the great central spring-wheat States Marquis out-yields the other Common spring-wheats, vet west of the Rocky Mountains, at various stations, Marquis is out-yielded by the standard varieties of soft white spring wheats and by several other varieties newly introduced. ${ }^{28}$ Marquis must therefore be considered as still on trial in the Pacific Northwest, and a few more years must pass before its exact position in respect to other wheats has there become a settled one.

In Montana, Marquis formed 45 per cent. of the wheat crop in 1917, as against 40 per cent. for winter wheat and 8 per cent. for Durum. Marquis out-yielded Durum, but was itself out-yielded by winter wheat to the extent of 3.2 bushels per acre. ${ }^{29}$ However, winter wheat in Montana is not a uniform success; for, in the principal spring-wheat sections of this State, early in the spring of 1916, a thaw followed by a frost killed most of the fallsown Turkey wheat. In consequence of this, a large part of the Turkev-wheat acreage was reseeded to Marqquis, which thus made a proportionate gain over its competitors. ${ }^{30}$

In order to realize the better with what speed Marquis has increased its cultivation in the four chief spring-wheat States, and to perceive the effect which Marquis has had upon other kinds of wheat in the vast struggle for varietal predominance upon the western plains, we shall now turm our attention to certain data recently published by the

28 C. R. Ball and J. Allen Clark, Experiments with Marquis wheat, Bulletin No. 400, Bureau of Plant Industry, U. S. Department of Agriculture, October, 1916, pp. 27, 35, 40, etc.

29 For these data, see the table which follows.

30 C. H. Bailey, loc. cit., p. 158. 


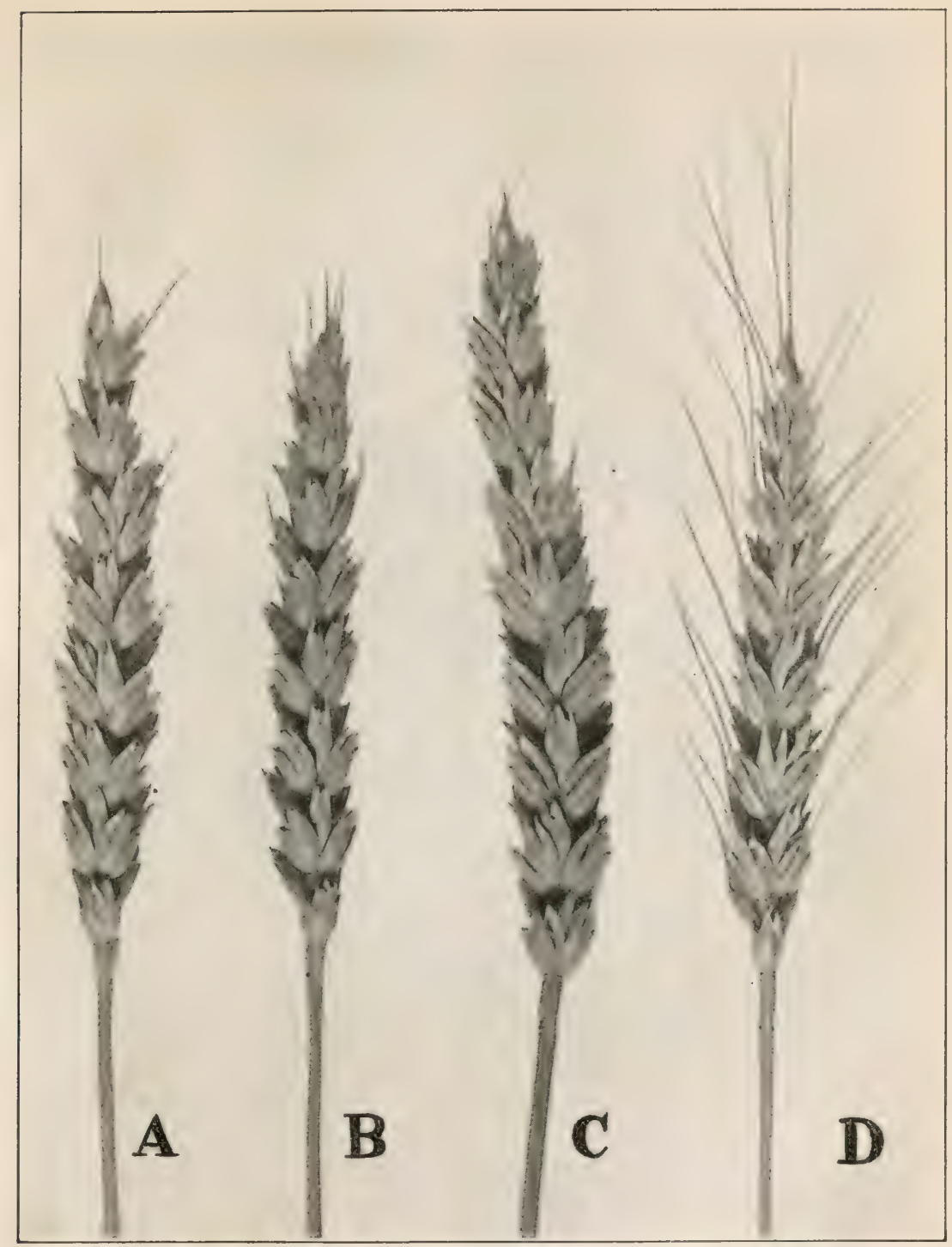

Fig. 29. Spike of Marquis wheat compared with spikes of Minnesota standard varieties. A, Minnesota Yo. 163 or Glyndon Fife: B, Marquis; C, Minnesota No. 169 or Harnes' Bluestem; D. Telvet ('haff (l'reston). Xatural size. From Bulletin No. 137 on Varquis Wheat by A. C. Arny and C. H. Bailey. Courtesy of the United States Department of Agriculture. 


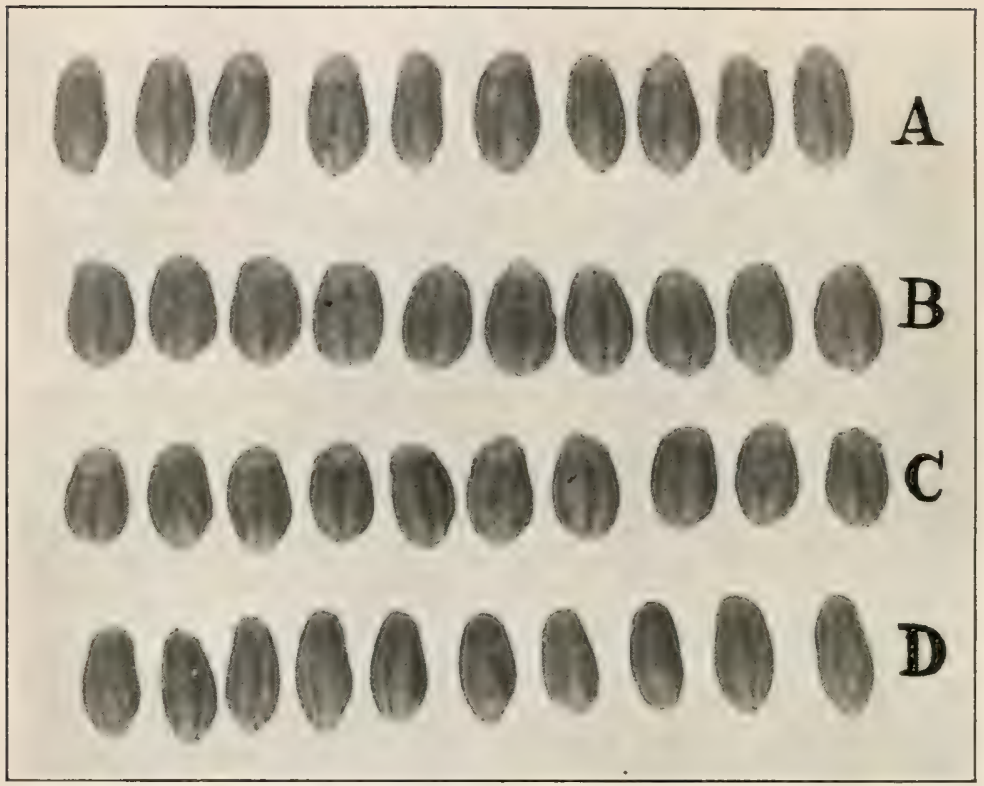

Fig. 30. Kernels of Marquis wheat compared with kernels of Minnesota standard varieties. A, Minnesota No. 169 or Harnes' Bluestem; B, Marquis; C, Minnesota No. 163 or Glyndon Fife; D, Telvet Chaff (Preston). Twice natural size. From Bulletin No. 137 on Marquis IIheat by A. C. Arny and C. H. Bailey. Courtesy of the L'nited States Department of Agriculture. 
Bureau of Crop Estimates at Washington. ${ }^{31}$ These data, reproduced below in their original tabular form, provide us with the estimated percentage which each important variety of wheat contributed to the crop of wheat in Minnesota and the two Dakotas in each of the years 191t, 1916 and 1917, and similar figures for Montana in 1917. For 1915, however, the estimates are lacking except for Durum. Velvet Chaff is another name for Preston.

Percentages of the Total Crop for the Chief Wheat Varieties

\begin{tabular}{|c|c|c|c|c|c|c|c|}
\hline & $\begin{array}{l}\text { Mar- } \\
\text { quis }\end{array}$ & $\begin{array}{l}\text { Velvet } \\
\text { Chaff' }\end{array}$ & $\begin{array}{l}\text { Blue- } \\
\text { stem }\end{array}$ & $\begin{array}{l}\text { Du- } \\
\text { rum }\end{array}$ & Fife & $\begin{array}{c}\text { Win- } \\
\text { ter }\end{array}$ & Other \\
\hline $\begin{array}{l}\text { MINNE- } \\
\text { SOTA }\end{array}$ & $\begin{array}{l}\text { Per } \\
\text { cent. }\end{array}$ & $\begin{array}{l}\text { Per } \\
\text { cent. }\end{array}$ & $\begin{array}{c}\text { Per } \\
\text { cent. }\end{array}$ & $\begin{array}{l}\text { Per } \\
\text { cent. }\end{array}$ & $\begin{array}{c}\text { Per } \\
\text { cent. }\end{array}$ & $\begin{array}{c}\text { Per } \\
\text { cent. }\end{array}$ & $\begin{array}{c}\text { Per } \\
\text { cent. }\end{array}$ \\
\hline $1917 \ldots$ & 46.0 & 26.0 & 18.0 & 3.0 & 3.0 & 3.0 & 1.0 \\
\hline $1916 \ldots \ldots$ & 30.7 & 28.9 & 30.8 & 2.2 & 3.8 & 3.3 & 0.3 \\
\hline $1915 \ldots \ldots$ & $\ldots$ & $\ldots$ & $\ldots$ & 1.9 & .. & ... & 98.1 \\
\hline $1914 \ldots \ldots$ & 3.0 & 30.0 & 52.0 & 2.0 & 7.0 & 2.0 & 4.0 \\
\hline \multicolumn{8}{|l|}{$\begin{array}{l}\text { NORTH } \\
\text { DAKOTA }\end{array}$} \\
\hline $1917 \ldots \ldots$ & 43.0 & 10.0 & 12.0 & 25.0 & 8.0 & 1.0 & 1.0 \\
\hline $1916 \ldots \ldots$ & 38.3 & 12.2 & 14.1 & 18.5 & 15.9 & 0.5 & 0.5 \\
\hline $1915 \ldots \ldots$ & ... & $\ldots$ & .. & 14.5 & ... & $\ldots$ & 85.5 \\
\hline $1914 \ldots \ldots$ & 5.0 & 11.0 & 45.0 & 13.0 & 21.0 & .. & 4.0 \\
\hline \multicolumn{8}{|l|}{$\begin{array}{l}\text { SOUTH } \\
\text { DAKOTA }\end{array}$} \\
\hline $1917 \ldots \ldots$ & 43.0 & 20.0 & 11.0 & 20.0 & 3.0 & 3.0 & .0 \\
\hline $1916 \ldots \ldots$ & 22.5 & 28.4 & 22.8 & 12.0 & 2.6 & 11.5 & 0.2 \\
\hline $1915 \ldots \ldots$ & ... & .. & ... & 22.7 & ... & $\ldots$ & 77.3 \\
\hline $1914 \ldots \ldots$ & 3.0 & 31.0 & 30.0 & 21.0 & 11.0 & 3.0 & 1.0 \\
\hline $\begin{array}{l}\text { MON- } \\
\text { TANA }\end{array}$ & & & & & & & \\
\hline 1917 & 45.0 & 1.0 & 3.0 & 8.0 & 2.0 & 40.0 & 1.0 \\
\hline
\end{tabular}

31 Monthly Crop Report for August, 1918, Bureau of Crop Estimates, U. S. Department of Agriculture, Washington, August, 1918, p. 95. 
An inspection of the Table shows us that the percentage of the total wheat crop contributed by Marquis increased from $191+$ to 1917 : in Minnesota from 3 to 46 per cent.; in North Dakota from 5 to 43 per cent.; in South Dakota from 3 to 43 per cent.; and in Montana from some small unrecorded amount to 45 per cent. Stated more generally, the figures indicate that Marquis increased in popularity in the great central spring-wheat region to such an extent that, although it formed less than 5 per cent. of the total crop in 1914 , by 1917 it had come to form nearly onehalf the total crop. But even this does not mark the final triumph of Marquis over its competitors, for it was again sown last spring in Minnesota, Torth and South Dakota, and Montana, in greatly increased measure. The actual figures for 1918 will not be arailable for some months, but Mr. C. R. Ball, of the Office of Cereal Investigations at Washington, has informed the writer that he believes that Marquis this year will contribute at least 65 per cent. to the total wheat crop of these four States, and possibly a little more.

It is interesting to note how the other varieties of wheat have withstood the onslaught of the invader from the north in the struggle for supremacy. Velvet Chaff (Preston) has about maintained its position in North Dakota but has decreased in Minnesota by 13 per cent. of its original amount in 1914, and in South Dakota by 35 per cent. Bluestem and Fife (Red Fife, Scotch Fife, etc.), have suffered disastrously. Bluestem, which in 1914 was facile princeps among the wheat sorts of Minnesota and North Dakota, and which shared an equal rule with Velvet Chaff in South Dakota. has decreased its crop since 1914: in Minnesota by 65 per cent., in North Dakota by 73 per cent., and in South Dakota by 63 per cent. It is evident that Marquis is rapidls replacing Bluestem in these States 
and that already in the space of four seasons it has cut down the cultivation of the older variety to one-third of what it was originally. Fife had much less ground to give up than Bluestem but, nevertheless, since 1914, its crop has decreased: in Minnesota by 57 per cent. ; in North Dakota by 62 per cent. and in South Dakota by 73 per cent.

Durum wheat, from which macaroni is made, as its name indicates, has very hard kernels, and it differs in various respects from the so-called Common. Wheats such as Velvet Chaff, Bluestem and Fife. ${ }^{32}$ Like Marquis, as the figures in the Table show, it is increasing in popularity in Minnesota and North Dakota, although not nearly so fast; but in South Dakota it is merely holding its place.

On account of climatic conditions, Winter wheat cannot be grown with much success in Minnesota and the two Dakotas, and is therefore never likely to be a serious competitor of Marquis in these States. In 1917 Winter wheat contributed only three per cent. to the total crop in Minnesota and South Dakota, and only 1 per cent. in North Dakota.

It is a remarkable tribute to the worth of Marquis that, nowthstanding its quite recent crossing of the International Boundary Line, it should have already thoroughly established itself as the leading kind of wheat in the chief spring-wheat States, and that it should now be cultivated, to some extent at least, in a continuous zone of States stretching from the Atlantic to the Pacific Ocean. The spring-wheat lands of Minnesota, the two Dakotas, and Montana pass by insensible gradations into the Canadian spring-wheat Provinces of Manitoba, Saskatchewan, and

32 Much Durum wheat is ground into flour at Minneapolis, and the flour, after being mixed with other sorts of flour, is used for making bread. 
Alberta. In this vast territory, in the spring of 1918 , Canadian and American farmers sowed Marquis upon about 20,000,000 acres; and, if one were to travel in summertime from the most southerly point in Nebraska where Marquis is grown, due northwards, through South Dakota and North Dakota, to the most northerly point in Saskatchewan where Marquis is grown, one would pass fields of Marquis for a distance of 800 miles. When one reflects that the thousands of millions of Marquis wheat-plants which turned from green to gold under the summer sun of this year, 1918, all had their origin in a single grain of wheat planted at Ottawa so recently as the spring of 1903 , one cannot help feeling that one is here presented with one of the most extraordinary examples of vcgetable increase that our planet has ever seen. This increase, which is probably a record for Flowering Plants, has been made possible: firstly, by the wonderful means of communication and transportation which are now everywhere available and, secondly, by the highly advantageous cooperation of the cerealists, seedsmen, grain merchants, millers, and farmers of two friendly nations. There are no more pleasant and mutually profitable invasions than those which are accomplished by battalions of wheat-plants from the North, and battalions of corn-plants from the South. May this delightful warfare long continue!

\section{General Description of Marquis}

Marquis is one of the hard red spring wheats and is classed among the beardless varieties, although, in common with Red Fife, White Fife, Glyndon, Haynes' Bluestem, etc., it carries a few short awns at the tip of the head. The head is of medium length and somewhat pointed at the tip. The chaff is smooth and of a straw-vellow color. The straw is somewhat shorter and less liable to lodge than 



\section{$E .8 Y \times 0$}

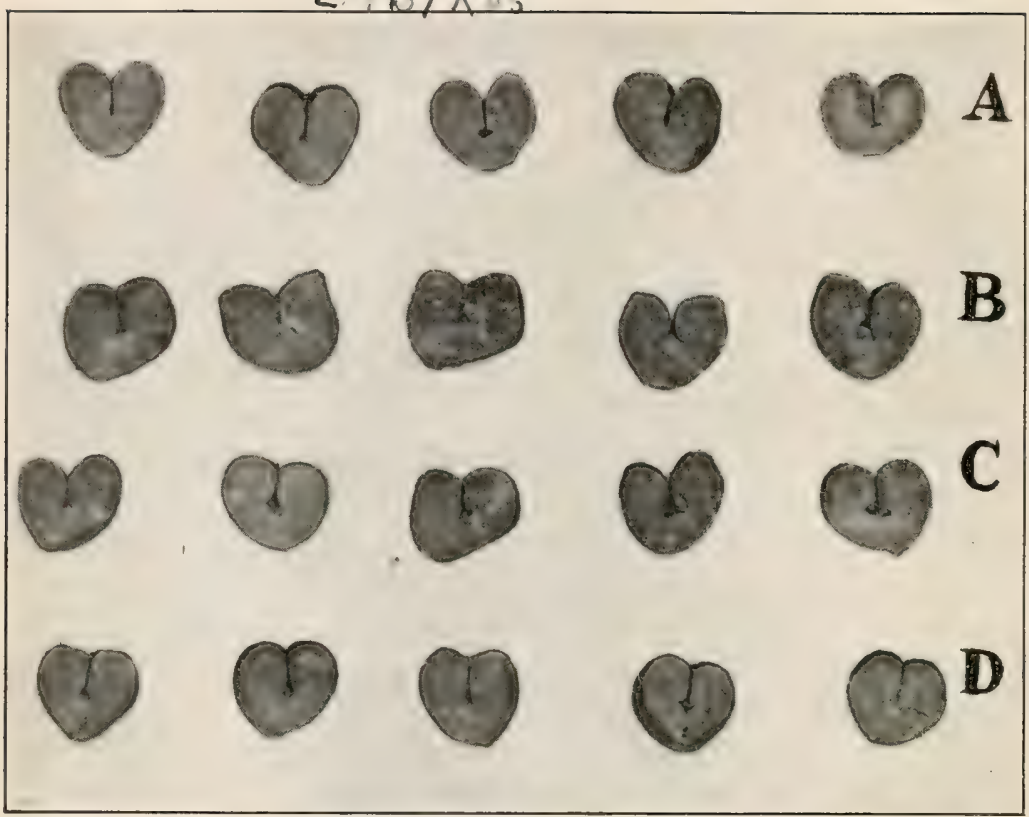

Fig. 31. Cross-sections of Wheat Kernels. Marquis compared with Minnesota standard varieties. A, Minnesota No. 169 or Haynes' Bluestem; B, Marquis: C', Minnesota No. 163 or Glyndon Fife; D, Velvet Chaff (Preston). Three times natural size. From Bulletin No. 137 on Warquis Wheat by A. C. Arny and (. H. Bailey. Courtesy of the Cnited States Department of Agriculture. 
that of most other varieties. The kernels are rather short, very plump, and of a particularly rich red color, qualities which make the wheat pleasing to the eye and admirable for exhibition purposes. The flour produced in the mill is of a pale cream-yellow color, similar to that of the old standard varieties, Red Fife and Bluestem; and, for the production of loaves of large volume, it is fully equal to, if not better than, that of the older sorts.

Messrs. Ball and Clark, of the Office of Cereal Investigations at Washington, have described Marquis, as grown in the United States, as follows:

"In all important characters Marquis closely resembles the wheats of the Fife group, so commonly grown in the northern Great Plains States. It is therefore included in the Fife group. It will be remembered that the Red Fife was the male parent of Marquis and that it doubtless was selected for Fife characters.

"The Marquis is a beardless spring wheat, with white glabrous glumes and broad and short hard red kernels. In general it differs from the true Fife varieties in its shorter straw, shorter spike, shorter glumes, and shorter, broader kernel.

"The plants are of only medium height, ranging from 28 to 48 inches, according to season. They generally are 2 to 4 inches shorter than those of the Glyndon and Power wheats. The straw is stiff and stands up well under unfavorable weather conditions. The spikes are short, varying from 2.5 to 4 inches in length. They average one-half to 1 inch shorter than those of other varieties of the Fife group. Two or three awns usually are found at the tip of the head, as in other beardless wheats.

"The glumes of the Marquis variety are short and broad. The variety usually can be recognized, even before the seed is ripe, by this character and by its lower stature. 
In spite of the short glumes the seed is held firmly and does not shatter.

"The kernels of other Fife wheats are short and broad, but those of the Marquis are even more so. They vary from 4.5 to 6 millimeters in length, areraging 5.2 millimeters, or nearly 1 millimeter shorter than the kernels of Fife and Bluestem wheats. The crease also is broader and deeper.

"The Marquis is an early variety, ripening from 98 to 135 days after sowing, varying with the season and locality. The average length of its growing period in the northern Great Plains is about 115 dars. This makes it three or four davs earlier than most of the other Fife varieties. Because of its earliness it escapes to some extent the drought of dry years, the rust and fall rains of wet seasons, and also the early fall frosts. These are the characters which have made it especially valuable in the Prairie Provinces of Canada.

"The growing season lengthens as one passes southward into the United States, and earliness is no longer so great an advantage." 33

\section{Prizes Awarded to Marquis}

The late James J. Hill, of the Great Northern Railway Company, offered a gold cup to the value of $\$ 1,000$ for the best bushel of hard spring wheat grown in the United States. Sir Thomas Shaughnessy challenged him to open the competition for the prize to Canada, but MIr. Hill was unwilling to do this. Sir Thomas, therefore, on behalf of the Canadian Pacific Railway Company, offered a new prize of $\$ 1,000$ in gold for the best bushel of hard spring

33 C. R. Ball and J. A. Clark, Experiments with Marquis Wheat, Bulletin No. 400, Tnited States Department of Agriculture, Washington, 1916, pp. 4-6. 
wheat grown on the continent of North America. In 1911 the international competition was held under the auspices of the New York Land Show and the prize was won by Mr. Seager Wheeler of Rosthern, Saskatchewan. ${ }^{34}$

Mr. Seager Wheeler, to whose Red Bobs further reference will be made in a later section, won the international prize in 1911 with a sample of Marquis wheat. From 5 lbs. of seed sent to him by Dr. Saunders from Ottawa in 1910, he obtained $250 \mathrm{lbs}$. of wheat and two sheares which were not threshed but which were estimated to contain at least $5 \mathrm{lbs}$. of grain each. This extraordinary yield was obtained on a strip of land measuring 15 by 155 feet, equal to about one-nineteenth of an acre and probably constitutes a world's record for spring wheat. ${ }^{35}$ The crop from the plot furnished part of the seed with which Mr. Wheeler won his first prize.

In 1912, Mr. Holmes of Raymond, Alberta, won the international prize, the competition being held under the auspices of the International Dry-farming Congress; and a similar honor came to Mrr. Paul Garlach of Allan, Saskatchewan, in 1913. In both these competitions it was Marquis which brought success.

In 1914 and 1915 Mr. Seager Wheeler again won the international prize with Marquis wheat; and in 1916 he repeated his suceess; but this time he showed his new variety which he selected from Marquis and which he has called Kitchener.

In the competition held in 1917 at the Twelfth Inter-

34 I am indebted to the Grain Growers Guide for the above particulars and for the names of the winners of the international prize.

35 For the facts concerning Mr. Wheeler's achievement, see the Report of the Dominion Cerealist in the Annual Report on Experimental Farms for 1911-12, Ottawa, 1913, p. 119. A calculation shows that the yield per acre was 81 bushels. 
national Soil Products Exposition, the international prize was again won with Marquis; and the winner was Mr. Samuel Larcombe of Birtle, Manitoba.

In the most recent competition, held in October of the present year, 1918, under the auspices of the Thirteenth International Soil Products Exposition at Kansas City, Mr. Wheeler was again the successful competitor. He showed samples both of Marquis and Red Bobs. Unfortunately, owing to some misunderstanding, no exact record was made as to which of these two varieties won the prize. Attempts made by the author to clear up this uncertainty have proved abortive. Owing to his having won the International prize five times, Mr. Seager Wheeler's name has been brought prominently before the public as that of one of the most successful grain growers on this continent.

From the above, we can draw the interesting conclusion that Marquis, or a derivative of Marquis, has won the international prize for a sample of the best hard spring wheat against all competitors from 1911 to 1917 inclusive, during a period of seven successive years.

\section{Long-Period Tests for Earliness and Yiold}

To show the practical advantage of growing Marquis wheat in respect to earliness and yield, some exact data will be cited. In plot tests on summer fallow land at Indian Head, Saskatchewan, in a series of eleven years, 1907-17 inclusive, Marquis showed an average increase of almost 40 per cent. over Red Fife and ripened its grains six days earlier than the older variety. ${ }^{36}$ In simi-

36 This percentage is either in pounds weight or bushels. Sixty pounds weight make one standard bushel of wheat according to law. The wheat is often weighed on the farm as it is being threshed and always weighed at the elevator when it is about to be stored; 
lar tests at Brandon, Manitoba, for the series of ten years 1908-17 inclusive, Marquis had an advantage over Red Fife of upwards of 20 per cent. and, just as at Indian Head, was six days earlier in ripening. ${ }^{37}$ These facts may be set out in tabular form as follows:

Indian Head: 1907-17 inclusive

Days from Seeding to Ripening Yield in lbs. per acre

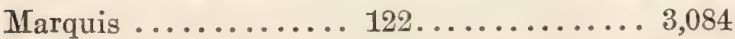

Red Fife ........ 128........ 2,210

Brandon: 1908-17 inclusive

Marquis ......... 107.........2,594

Red Fife ........ 113........ 2,148

The earliness of Marquis, as compared with Red Fife, Bluestem, etc., brings with it a number of solid advantages; and these we shall now proceed to discuss.

\section{Eartiness and the Gain of Working-Time}

Owing to the fact that Marquis ripens its grains a full six days sooner than Red Fife, the farmer who grows the former variety of wheat is given almost an extra week between harvest and freeze-up for the preparation of his land for the next year. In the Prairie Provinces,

and the number of bushels is calculated from the weight in lbs. by dividing by 60 . At an elevator, after the number of bushels of wheat in a delivery has been estimated in this way, the weight of the wheat contained in a bushel measure is found by testing a sample. If the weight should be less than $60 \mathrm{lbs}$., the grading is affected adversely. No. 1 Manitoba Hard and No. I Northern must weigh at least $60 \mathrm{lbs}$, and No. 2 Northern at least $58 \mathrm{lbs}$. Poor wheat may weigh as low as $55 \mathrm{lbs}$. to the measured bushel while good wheat often weighs 64 lbs.

37 Vide Reports of Superintendents of Experimental Farms at Indian Head and Brandon, 1908 and following years. The data in the Tables were kindly compiled for the writer by the Dominion Cerealist. 
where at best only a few weeks intervene between the gathering of the crops and the hard frost of winter, the practical advantage of the six-day gain is often very considerable.

\section{Earliness and Storms}

The early ripening habit of Marquis is prized in Minnesota, as well as in some other parts of the spring-wheat belt, because it lessens the time during which the standing crops must be exposed to the dangers of inclement weather. In that State, when it has become evident that there is going to be a fine rield and the wheat kernels are in the dough stage or ripening, and when it is yet a little too early to begin cutting, the sight of storm-clouds looming up upon the horizon makes the farmers vers apprehensive; for the heavier the stand and the greater the prospective vield, the greater is the danger of severe lodging by rain and wind, and of destruction by hail. Every day that the uncut grain is exposed in the fields, the risk of damage is lengthened; and the harvesting of the crop a week sooner owing to the early ripening habit of Marquis, often prevents serious disaster.

\section{Earliness and Rust}

Another great advantage connected with earliness in Marquis is the diminished risk of loss from Black Stem Rust. The disease is caused by a parasitic fungus known as Puccinia graminis which settles in the form of microscopic spores upon the leares and hanlms of the wheatplant, penetrates through the epidermis when the weather is moist and warm, appropriates for its own uses much of the sugar manufactured br the leaves, and thus interferes with the passage of this important substance to the grains where normally it is destined to be converted into 
starch. When the fungus has been growing within the tissues of the wheat-plant for about a week, red powdery pustules break out, particularly upon the leaf-sheaths and stems. These may become gradually larger and more conspicuous, and their number may increase as the infection spreads; but, sooner or later, they pass away and are replaced by black pustules which persist on the straw through the winter. Both the red and the black pustules consist of spores which resemble in function the seeds of Flowering Plants, for they serve to reproduce the parasite and permit of its continuing its life-cycle. The action of the Rust-fungus upon the wheat-plant causes a greater or lesser shriveling of the grains. The consequence of an attack of Rust to the farmer, therefore, is a greater or lesser diminution of the yield of wheat at harvest time. Now, during the great Rust epidemic ${ }^{38}$ of 1916 , it was observed in many localities that the fields of wheat which ripened earliest, suffered least from the disease. This is easily explicable if one realizes: that the Rust-fungus is a plant, that it therefore requires food for its growth, and that it naturally flourishes best in wheat-plants which are richest in sugars and proteins. When the fungus attacks a younger wheat-plant, with its grains only in the milk or in the dough stage, the straw is still rich in all those substances which enable the parasite to vegetate luxuriantly, for these have not yet been transferred to the heads. On the other hand, when the fungus attacks an older wheat-plant, with its grains ripening, the straw is well advanced toward exhaustion, for a considerable volume of its sugars and proteins has already passed up into the grains which in consequence have become partially filled.

38 Plant pathologists in North America are now discarding the term epidemic as applied to plant diseases and are using the term epiphytotic instead. To avoid misunderstanding, I have not adopted this innovation here. 
Whereas, therefore, the younger wheat-plant forms a highly suitable medium for the parasite, enabling it to flourish for a long time, the older one forms a relatively poor medium within which the growth of the parasite soon comes to an end. It follows from this, and from the fact that a Rust epidemic, when it comes at all, usually comes late in the growing season, that the earlier wheat is planted, the less likely is it to suffer severely from Black Stem Rust. But the hastening of the maturing process may be obtained by growing early-maturing varieties such as Marquis. In 1916, where Marquis and Red Fife were sown at the same time, Marquis withstood the attack of the Rust disease far better than Red Fife owing to its sixday earlier ripening habit. This was noted, for example, in the plot tests at the University of Saskatchewan at Saskatoon by Professor John Bracken who, in his Lessons from the Rust Epidemic of 1916, recommends the planting of early-maturing varieties of wheat as one means of combating the Rust disease. ${ }^{39}$

Marquis, while to a certain extent rust-escaping owing to its earliness, is not rust-resistant. If it could be made rust-resistant by replacing its rust-susceptible character by a rust-resistant one (much in the same way as one may remove a single bad brick from a building and replace it by a sound one), it would be considerably improved. Possibly, some day, our farmers may be provided with a wheat as good as Marquis which resists most of the fungus diseases which now diminish the yield, such as Rust, Smut, Wheat Scab, and Root-rots. In any case, a serious attempt must be made to breed such an ideal plant, howerer long and difficult may be the task. Already in England,

$39 \mathrm{~J}$. Bracken, Lessons from the Rust Epidemic of 1916, Bull. No. 50, Dept. of Agriculture for Saskatchewan, Regina, 1917, pp. 11,15 . 
the yearly toll taken by $Y$ ellow Stripe Rust (a disease not occurring in Canada) has been reduced by the breeding of a rust-resistant wheat by Professor R. H. Biffen of Cambridge University. The new wheat is called Little Joss and originated from a cross between the rust-susceptible Square Head's Master, one of the most widely cultivated English wheats, and a mist-resisting Ghurka wheat from Russia. ${ }^{40}$ Professor Biffen's success in obtaining Little Joss was largely due to the fact that his efforts were guided by the light of Mendel's principles of inheritance. These celebrated principles were working out from a study of the effects of crossing varieties of the Eating Pea, in a cloister garden, by Gregor Mendel, a monk, in 1873; and their application by Professor Biffen in the task of producing a rust-resistant wheat suited to English soil, affords another remarkable instance of the way in which Pure Science provides Applied Science with her tools. The latest report shows that Biffen's rust-resistant Little Joss is now the chief wheat grown in the Eastern Counties of England, that it is spreading rapidly over other parts of the country, and that owing to its resistance to Yellow Stripe Rust which attacks other wheats year after year, it has a yield of 40 bushels to the acre instead of 36 as given by Square Head's Master, as the average for a seven-year period in test plots. ${ }^{41}$ These significant facts have been noted both in the United States and in Canada. At the present time, Professor Stakman, Dr. Hayes and others at the University of Minnesota are engaged in a campaign to breed first-class bread-wheats which are resistant to Black Stem Rust; and, at the University of Saskatchewan,

40 R. H. Biffen, Systematized Plant-Breeding, an essay in Science and the Nation, edited by A. C. Seward, Cambridge, 1917, p. 157.

41 Ibid., pp. 157, 158. Each bushel was 63 lbs. On farms, away from the Experimental Station, Little Joss yielded 5 to 10 per cent. per season more than Square Head's Master. 
Professor W. P. Thompson is studying the problem of rust-resistance with a view to a solution of it for this country in the near or distant future. Up to the present, however, the greatest contribution to the task of combating Rust in Canada has been made by Dr. Saunders through the introduction of early-maturing Marquis wheat. The losses to the wheat crop through Black Stem Rust in the year 1916 were about $100,000,000$ bushels in Canada ${ }^{42}$ and $140,000,000$ in the United States; ${ }^{43}$ and, doubtless, they would have been considerably greater, had not Marquis with its early ripening habit alrearly by that time so largely supplanted later-maturing varieties such as Red Fife and Bluestem. ${ }^{44}$

\section{Earliness and Frost}

Owing to its earliness, Marquis is less liable than Red Fife, ete., to be injured by early frosts in the colder sections of the wheat-growing area. In the greater part of the southern and central prairie region of Alberta, Saskatchewan, and Manitoba, the first destructive frost usually oceurs between September 6 and September 12 . In this renion, Marquis, and nsually also Red Fife, ripen their grains sufficiently early to escape this frost. Further north, the first destructive frost frecuently occurs from August 27 to September 2. In this region, Marquis usually ripens early enough to escape the frost, but Red Fife often suffers from it very severely. Still further to the north, and in less farored districts, the first destructive frost comes from August 20 to August 26. This

42 Estimate made by the writer from a study of data collected by the Secretary of the Winnipeg Grain Exchange.

43 Estimate kindly sent to the writer in a letter by M. A. Carleton, cerealist for the U. S. Department of Agriculture.

44 Bluestem ripens later than Red Fife, and is therefore very little grown in Canada, though well known in the U. S. A. 
very early coming on of cold weather usually prevents Red Fife from ripening at all, and even seriously affects Marquis.

There can be no question that the early-ripening habit of Marquis is a most valuable character so far as escaping early frosts is concerned, and that it has already brought about in Canada a saving of great quantities of wheat which in its absence would have been spoiled.

The farther north man makes his abode and seeks his sustenance, the more necessary is it for him to grow early-maturing wheats. Dr. William Saunders, many years ago, introduced Ladoga, which ripens about ten days earlier than Red Fife, into the Peace River valley. At Dunvegan and at Fort Vermilion, 414 miles and 591 miles by latitude due north of Winnipeg respectively, this wheat has been raised in goor condition, so that it weighed per bushel 64 lbs. at the former place and $60 \mathrm{lbs}$. at the latter. Mr. J. M. Macoun, after making investigations on the spot, reported that in 1903 about 7,500 bushels of wheat had been raised in the neighborhood of Vermilion and that one of the settlers there had obtained 40 bushels per acre from 50 acres. Even at Fort Simpson, which is situated on the Mackenzie River, $\$ 18$ miles by latitude north of Winnipeg and ouly 324 miles south of the Arctic Circle, the early-maturing Ladoga has been successfully raised, so that it weighed $62 \frac{1}{2} \mathrm{lbs}$. to the bushel. In this instance, however, a small percentage of the grain was injured by frost. ${ }^{45}$

45 Experimental Farms Report for 1903, p. 11. The Hudson's Bay Company long had a roller mill at Vermilion. In 1903 it had a capacity of 20 barrels a day. At that time the Company was giving $\$ 1.50$ per bushel for all wheat grown in the vicinity with the object of supplying all their northern posts with Vermilion flour. Recently Vermilion became comected with Edmonton by means of the Edmonton, Dunvegan, and British Columbia Railway and by steamship service. Flour is now taken northwards to Vermilion 
The nearer one approaches to the Arctic Circle in summer, the longer are the days and, other things being equal, the greater is the amount of light to which wheatplants are subjected during the growing season. Dr. William Saunders found that the same kind of wheat grown at Ottawa took on an average of three years 106 dars to ripen but grown at Vermilion only 101 days, and he ascribed this difference to the difference in the amount of sunlight in the two places. It is possible, however, that differences in the amount of available moisture and heat were also important factors in bringing about the result. In support of his view Dr. William Saunders recalled the work of a Russian investigator named Kowalewski. Kowalewski grew spring wheat and oats in different parts of Russia, from the north at Arkangelsk to the southern province of Kherson, and made careful observations on the time of ripening. He found that in higher latitudes the grain ripens in a shorter period than in the more southern districts, the difference varying at different points from 12 to 35 days. Kowalewski attributed the earlier ripening in the north largely to the influence of light during the long summer days, but he also believed that the short seasons of quick growth had brought about in these cereals an early-ripening habit. Dr. William Saunders, however, regarded this habit as a fixed one which cereals continue to manifest when gruwn in localities where the summer season is longer. ${ }^{46}$ Whatever may be the exact reason for the hastening of the maturation of one and the same spring wheat when grown in higher latitudes, the fact remains that this hastening must be of distinct adrantage in lessening the danger from early frosts.

by this route and the Hudson's Bay Company, in consequence, has ceased to operate its Vermilion mill.

16 Ibid. 
At Fort Vermilion, in 1909, 35,000 bushels of wheat were grown with an average yield of 24 bushels per acre. The wheat varieties with which this success was obtained were all more or less early ones and included Ladoga, Preston, Early Riga, and Riga. ${ }^{47}$

In the spring of $1917,9,000$ bushels of wheat were shipped from Fort Vermilion to Fort William by Mr. Sheridan Lawrence from his own farm. The wheat was transported upon the steamship D. A. Thomas 280 miles up the Peace River, then 311 by the Edmonton, Dunvegan and British Columbia Railway to Edmonton, and finally 1,446 miles by rail from Edmonton to Fort William, the total distance being 2,037 miles. The long haul and high freight rates were overcome by the high price for wheat prevailing at that time. This, however, is not a normal condition and, until railway facilities are provided for shipping the grain, the Fort Vermilion district must find its markets nearer home. Upon his farm Mr. Sheridan Lawrence has operated a stone flour mill for over twenty years and recently has had a roller mill installed. ${ }^{48}$ These facts indicate some of the possibilities of the Northland.

\section{Marquis, Ruby, and Prelude}

To meet the exigencies due to short seasons in the northern parts of the Prairie Provinces, Dr. Saunders has striven to produce new kinds of wheat which, in addition to having a high yield and the excellent baking and milling qualities of Marquis, ripen even earlier than this variety. One of these wheats, an approximation to his ideal, which

47 Experimental Farms Reports for 1909, p. 7.

48 F. H. Kitto, The Peace River District, its Resources and Opportunities, Department of the Interior, Natural Resources Intelligence Branch, Ottawa, 1918, p. 41. 
was introduced a few years ago and is being successfully grown in various districts where the season is short, he has called Prelude ${ }^{49}$ because it ripens at the very beginning of the wheat harvest, some two weeks sooner than Marquis. With the coming into existence of such wheats as Marquis and Prelude, it has been made possible to extend the profitable wheat-growing area of Canada much farther toward the North where the seasons are shorter. It may be added that the name Prelude naturally suggested itself to Dr. Saunders as appropriate owing to his love of music. Prelude is a musical term for a preliminary air. ${ }^{50}$

The breeding of Prelude has by no means ended the attempts of Dr. Saunders to develop varieties of wheat suited to the short seasons of the North. His most recent introduction he has called Ruby Wheat on account of the reddish hue of its ripe kernels. As compared with Pre-

49 C. E. Saunders, Prelude Wheat, Experimental Farms Reports for 1911-12, Ottawa, 1913, pp. 117-118.

50 The particular distriets for which Prelude is recommended are Northern Saskatchewan and Northern and Central Alberta; and it is in these that this variety of wheat ripens two weeks earlier than Marquis. There is less difference in the time of ripening in districts where the summer is warmer. Prelude is now grown, sometimes on a considerable scale, at rather high altitudes in Alberta and at northern latitudes in Saskatchewan. It has been ripened in Dawson City in the Yukon. At present it is impossible to say with certainty how much farther North one variety ean be grown than another, owing to the incompleteness of the tests which have been macie hitherto. In attempting to make comparisons, the variation in the seasons becomes a complicating factor. Even late-maturing wheats can be grown in favorable spots and in favorable seasons in high latitudes, although such successes do not by any means represent the average for a number of consecutive seasons. Thus Red Fife sometimes ripens on the farm where tests are made for the Dominion Government at Fort Vermilion on the Peace River, 650 miles north of the International Boundary-line; but this is quite exceptional, and Red Fife is not at all suitable for the Peace River country as a whole, year in and year out. Marquis and other early-maturing wheats do much better in this far distant region of the North. 


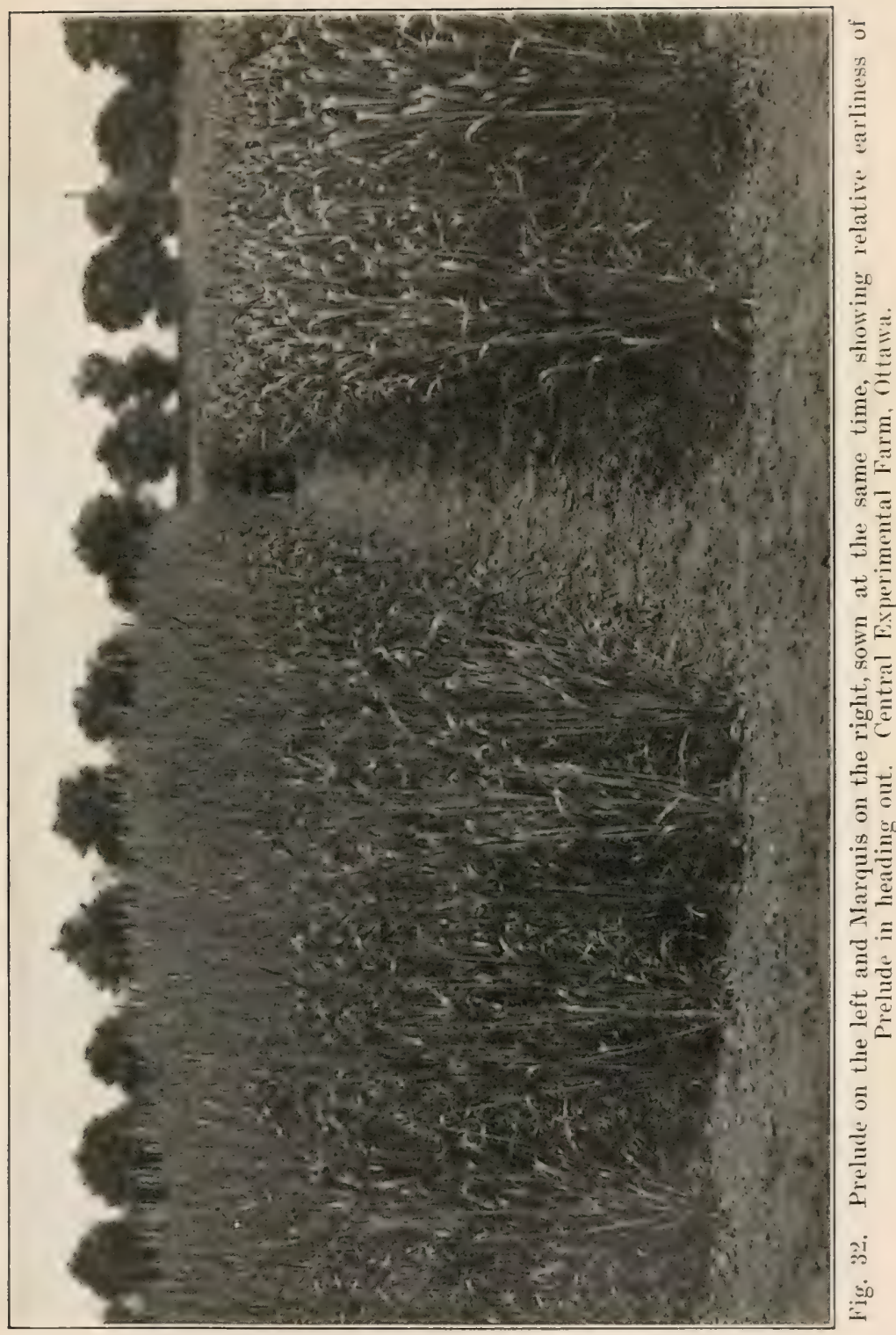



lude, Ruby does not shatter so readily, has longer straw, has a larger rield, is beardless instead of being bearded, but is a few days later in ripening its grains. It is now being rapidly tested in the West. It mar supplant Prelude to a greater or lesser degree but is not expected to replace Marquis in those more southerly districts where the latter does so well.

Marquis ripens about one week earlier than Red Fife, Ruby about two weeks and a half earlier, and Prelude more than three weeks earlier. ${ }^{51}$ The length of straw and the yield vary inversely as the earliness. Thus Prelude, the earliest of the three wheats, has the shortest straw and the least rield; Rubr, which is intermediate in earliness. has straw of intermediate length and has an intermediate yield; while Marquis, the least early of the three wheats, has the longest straw and the best yield.

It is evidently not an easr matter to combine extreme earliness with a very high rield; and this is not surprising, for the earlier a wheat is, the shorter is its growing period, and the less is the time at its disposal for manufacturing the starch and proteins which are required to fill the grains. Other things being equal, extreme earliness and high vield are mutually antagonistic qualities. It is unthinkable that wheat should ever be introduced which would ripen in serenty dars and yield from thirty to fifty bushels per acre, nor does it seem at all likely that cereal breeders will erer succeed in producing a wheat which combines the extreme earliness of Prelude with the very high productivity of Marquis. Becond a certain point increased earliness can ouly be selected at the expense of high yield, and vice versa.

51 At the Indian Head Experimental Farm, in 1918, Ruby was several dașs earlier in ripening than Mr. Seager Wheeler's Red Bobs. Observations of the Superintendent of the Farm and of the auther. 
Marquis, Ruby and Prelude were all produced by crossbreeding. Marquis resulted from a single cross, Ruby from two successive crosses, and Prelude from three successive crosses. Their respective genealogical trees may be represented as follows:

\section{Parentage of Marquis}

Hard Red Calcutta (f.) $\times$ Red Fife (m.) ......A. P. Saunders, 1892

Marquis

\section{Parentage of Ruby}

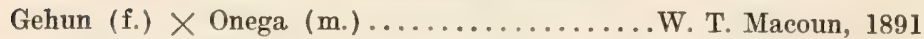

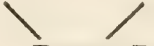

Downy Riga (f.) $\times$ Red Fife (m.) .....C. E. Saunders, 1905

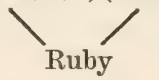

\section{Parentage of Prelude 52}

Ladoga (f.) $\times$ White Fife $(\mathrm{m}.) \ldots \ldots \ldots$..... P. Saunders, 1888

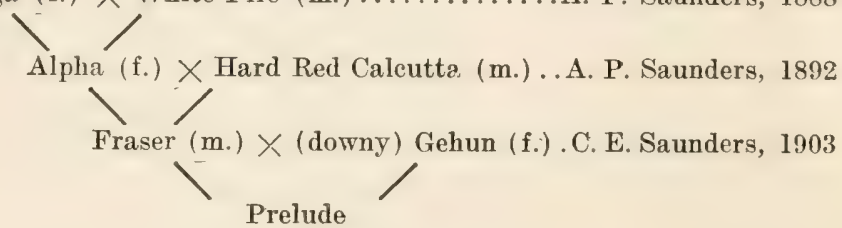

Hard Red Calcutta and Gehun were brought to Canada from India, and Ladoga and Onega from northern Russia. Red Fife came from central Europe (probably Galicia) via the ports of Danzig and Glasgow; and White Fife is believed to be one of its derivatives. ${ }^{53}$ Marquis, Ruby,

52 C. E. Saunders, Experimental Farm Reports for 1911-12, Ottawa, 1913, p. 118.

53 W. Saunders, Ladoga Wheat, Central Experimental Farm, Bulletin No. 4, 1889, p. 4; also C. E. Saunders, Evidence before the Select Standing Committee on Agriculture and Colonization, Ottawa, 1905.

Red Fife is named after David Fife upon whose farm Red Fife orig- 
and Prelude have therefore had a somewhat complex origin. However, each of them, in a greater or lesser degree, embodies the earliness of its Indian or Russian ancestors with the good milling and baking qualities of Canadian Red Fife or White Fife. The production of such cross-bred wheats to meet the requirements of agriculture is one of the most remarkable developments of modern botany.

XVI. The Advance Toward the North of the Belts of Wheat and Corn

The pushing up of the wheat-belt in Canada toward the North, owing to the discovery and introduction of new early-maturing varieties, finds an interesting parallel in the northerly advance of the belt of Indian corn in the United States. The original corn-belt was situated in Ohio, Indiana, Illinois, Iowa, and Nebraska; but now corn culture is undertaken on a considerable scale in Minnesota, South Dakota, and North Dakota. The northerly extension of the corn-belt by several hundreds of miles was accomplished by the introduction of new varieties of corn with early-ripening characteristics, two of the chief ones being known as Minnesota No. 13 and Minnesota No. 23. The former is a uniform Yellow Dent, and the latter a white-capped Yellow Dent. Minnesota No. 13 was discovered by Professor Andrew Boss of the University of Minnesota. Professor Boss in 1890 obtained two bushels of Yellow Dent from De Cow and Company, seedsmen of St. Paul, planted the grains at the University inated in 1841 from a sample of wheat which was obtained by a friend from a cargo of wheat which had arrived at the pcrt of Glasgow from Danzig on the Baltic coast. Dr. C. E. Saunders has shown that it is identical with a wheat still grown in Galicia. Vide Section XXIII on The Origin of Red Fife. 
Farm, and made selections for earliness. He thus originated a strain which became known as Minnesota No. 13 and which, instead of taking 120 to 125 days to ripen like the Yellow Dent variety then most grown, matured in from 100 to 110 days. The development of Minnesota No. 13 made it possible to grow corn much farther northward from the southern boundary of Minnesota than had previously been the case. But another great step in the pushing northward of the corn-belt was soon to follow through the introduction of Minnesota No. 23, which was even more remarkable than Minnesota No. 13 in its earlymaturing properties. Minnesota No. 23 was discovered by Professor Boss on a farm at Mentor, near Hendrum, in Norman County, Ninnesota, only 120 miles south of the International Boundary-line. It was being grown by a farmer named Jacob Berg, but how it came into his possession is not known. Professor Boss noticed its unusual earliness, obtained a sample of it in 1893, and propagated it at the Minnesota Experimental Station. A selection of it, made by Professor C. P. Bull in 1905, was increased in quantity and finally distributed as seed. The new Minnesota No. 23 was found to ripen in the very brief period of about 90 days, and this led to its being grown as far north as the upper boundary of Minnesota and in North Dakota. ${ }^{54}$. Just as the profitable corn-belt in North America was thus pushed northwards in two steps by the successive introduction of Yellow Dent Minnesota No. 13 and Yellow Dent Minnesota No. 23, so, too, in more recent years, has the profitable wheat-belt been pushed northwards by the successive introduction of Marquis and Prelude.

The northward advance of the corn-belt has made a

54 The facts in this paragraph concerning corn were kindly supplied by Professor Boss. 
profound difference to Minnesota, for in that State about 25 years ago a farmer was considered a gambler who attempted to grow Dent Corn north of the southern third of the State (above the so-called St. Clond Line); but now all this is changed, for there is actually more corn raised today in Kittson, the north-west corner county of Mimmesota, than used to be raised a generation ago at Houston, the south-east corner county of the State. ${ }^{55}$ At the present time, when one travels through Minnesota by rail in the summer, one observes scattered everywhere, from north to south and from east to west, rich ficlds of dark-green corn; and silos for the fermentation and storing of corn ensilage for feeding stock have become a characteristic feature of the landscape. ${ }^{56}$ Further evidence of the agricultural importance of the early-ripening Yellow Dent varieties is afforded by the fact that Minnesota in 1917 produced 90,000,000 bushels of corn and North Dakota in $1916,13,500,000$ bushels. $^{57}$ Nanitoba is not within the corn-belt, for corn, as a rule, does not ripen in that Province owing to the shortuess of the growing season. Nevertheless, when corn is sown in the warmer districts about the middle of May, it grows rapidly during the long bright days, attains a height of from 6 to 8 feet, and rields often as much as 10 to 15 tons of green fodder to the acre. This is made into ensilage or stocked in the fields until required for feeding. ${ }^{58}$ It proves to

55 Communicated by Professor Boss.

56 Ensilage is the most economical method of treating corn for feeding animals. Both stalks and green leaves are run through the cutter. After fermentation the ensilage can be kept with safety all through the winter.

57 Year Book of the U. S. Department of Agriculture for 1917, p. 608.

$58 \mathrm{Cf}$. A Handbook to Winnipeg and the Province of Manitoba, prepared for the Winnipeg meeting of the British Association for the Advancement of Science, article on Agriculture by R. P. Roblin and W. J. Black, 1909, Winnipeg, pp. 72, 73. 
be excellent for fattening cattle and is one of the best foods for milch cows. The pushing northward of the corn-belt has therefore directly affected agriculture in the Prairie Provinces. The story of the northward advance of the corn-belt seems to warrant the belief that eventually vast tracts of land in northern Canada which have not yet been plowed, will one day be made to raise early-ripening varieties of wheat such as those which Dr. Saunders is now perfecting. ${ }^{59}$

\section{The Yield of Marquis in Western Canada}

In the greater part of Saskatchewan, on summer fallow, one is safe in saying that the yield of Marquis over Red Fife is at least 20 per cent. The situation in Central and Northern Manitoba is about the same as in Saskatchewan. In Alberta the climatic conditions are more complex than in Saskatchewan and Manitoba, so that for that province it is difficult to make exact statements of the yield of Marquis compared with that of other varieties.

On stubble land Marquis often appears to be no better than, or about the same as, Red Fife, provided that the

59 In Manitoba, the chief variety of corn now grown is Northwestern Dent, the next variety in importance being Minnesota No. 13. The cobs ripen in this Province only in exceptional seasons. In 1914, when the mean shade temperature for July was $70^{\circ} \mathrm{F}$., the cobs of certain Flint varieties (Quebec No. 28 and Free Press) ripened well, while the cobs of the Dent varieties ripened only partially. There are about 100 silos in Manitoba. Information supplied by Mr. Allan Campbell at the Brandon Experimental Farm.

Northuestern Dent is a variety of Red Dent corn that is not related in any way to either Minnesota No. 13 or Minnesota No. 23. It has been grown to a considerable extent in the two Dakotas, Montana, and Minnesota, and to some extent in northern Michigan and Wisconsin. There is no authentic history of this variety, and no one appears to know where or how it originated. Information supplied hy Professor Andrew Boss of the Lniversity of Minnesota. 
season is long enough to ripen both sorts. Where the season is very short, Marquis, even on stubble, etc., has the advantage because it ripens its grains earlier than Red Fife.

The yield of Marquis in the field in western Canada is often very high and a few of the more noteworthy crops may be mentioned. In 1909 a field of $4 \frac{1}{3}$ acres at Bran-

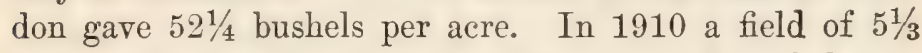
acres at Indian Head gave a little over 53 bushels per acre. But these records were surpassed in 1911 at the Experimental Station at Rosthern, Saskatchewan, when a $1 / 40$-acre plot yielded at the rate of 70 bushels per acre. It was in this same year that Mr. Seager Wheeler ${ }^{60}$ on a $1 / 19$-acre plot at Rosthern, obtained a yield at the rate of 81 bushels per acre. ${ }^{61}$

Mr. C. S. Noble, who is operating a 15,000-acre farm in Alberta, purchased a limited supply of Mr. Seager Wheeler's registered Marquis seed wheat in 1913. From this, by propagation, he obtained a sufficient supply of grain to seed 1,000 acres in 1916. From this 1,000-acre

60 For all of the above data vide Report of the Dominion Cerealist in Report on Experimental Farms for 1911-12, Ottawa, 1912, p. 119. The nature of MIr. Wheeler's plot and yield is given in Section IX on Prizes auarded to Marquis. The field crops cited for Brandon and Indian Head excelled the plot records at both the Brandon and Indian Head Experimental Farms.

61 Record Yield of Wheat-According to the United States Monthly Crop Report of July, 1918, the largest yield per acre of wheat ever recorded is, so far as ascertained by the Bureau of Crop Estimates, 117.2 bushels. It was produced in 1895 in Island County, Washington, on a field of 18 acres. The farm on which this crop was grown consisted of a clearing of 85 acres of black sandy loam with a clay subsoil. It has been farmed for over 30 years, is not irrigated, but is well diversified. No fertilizer has ever been used on this farm. The variety of wheat sown was Australian Club. The field that produced the record yield was in pasture for cattle and sheep for several years, and for three years prior to producing the yield of wheat was seeded to potatoes. 
field he threshed 54,395 bushels of wheat which gives a rate of $54 \frac{1}{2}$ bushels per acre. ${ }^{62}$

\section{The Yield of Marquis in the United States}

The yield of Marquis in the United States has been carefully studied by a number of observers. The first Bulletin dealing with this subject was published by Professor A. C. Arny of the Minnesota Agricultural Experiment Station early in 1914, ${ }^{63}$ and another by Messrs. C. R. Ball and J. A. Clark in $1916{ }^{64}$ In the more recent Bulletin, which is very comprehensive, reports on yield have been brought together from 23 stations scattered in 13 different States. The area of observation stretched from Iowa and Minnesota on the east to California and Oregon on the west, and included all the intervening States except Washington. In this great expanse of territory, the conditions of climate and soil vary greatly; and it was only to be expected that the relative rield of Marquis would vary considerably with local conditions. Mlessrs. Ball and Clark concluded from their data which provided yields for three years, that, in the Northern Prairie States and in the Great Plains area, Marquis gives a higher yield than other Common spring wheats but that, west of the Rocky Nountains, it is outyielded by the standard varieties of soft white spring wheat and by several newly introduced varieties. They also found that, under irrigation, Marquis had done fairly well in limited experiments east of the Rocky Mountains but not at two stations to the west

62 Better Seed Book, The Grain Growers' Guide, Winnipeg, 191718, p. 4.

63 A. C. Arny, Marquis Wheat; I, History and Culture, Minnesota Wheat Investigations, Bullet in No. 137, Series II, Feb., 1914.

64 C. R. Ball and J. A. Clark, Experiments with Marquis Wheat, Bulletin No. 400, Bureau of Plant Industry, U. S. Department of Agriculture, Oet., 1916, pp. 1-40. 
of this range. In what follows we shall concern ourselves solely with the States of Minnesota, North Dakota, South Dakota, and Montana, where most of the spring wheat is grown.

In the great spring-wheat region of the United States, Marquis gives an excellent yield, as is evident from the following Table reproduced from a Monthly Crop Report recently published at Washington. ${ }^{65}$ The Table gives the estimated number of bushels per acre for each important variety of wheat in Minnesota and the two Dakotas in the years 1914, 1916, and 1917, and similar figures for Montana in 1917. The data for the abnormally large crop year of 1915, unfortunately, are not included. Here again, Velvet Chaff is another name for Preston.

Yield of Wheat Varieties in Bushels per Acre

\begin{tabular}{|c|c|c|c|c|c|c|c|}
\hline & $\begin{array}{l}\text { Mar- } \\
\text { quis }\end{array}$ & $\begin{array}{l}\text { Velvet } \\
\text { Chaff }\end{array}$ & $\begin{array}{l}\text { Blue- } \\
\text { stem }\end{array}$ & Durum & Fife & Winter & Other \\
\hline $\begin{array}{l}\text { MINNE- } \\
\text { SOTA }\end{array}$ & Bush. & Bush. & Bush. & Bush. & Bush. & Bush. & Bush. \\
\hline $1917 \ldots \ldots$ & 17.2 & 16.0 & 14.0 & 15.5 & 15.0 & 20.0 & 14.0 \\
\hline $1916 \ldots \ldots$ & 11.0 & 7.4 & 5.5 & 8.5 & 6.9 & 14.0 & $\ldots$ \\
\hline $\begin{array}{l}1914 \ldots . . . \\
\text { NORTH } \\
\text { DAKOTA }\end{array}$ & 12.8 & 11.6 & 9.8 & 12.3 & 10.3 & 19.5 & 11.0 \\
\hline $1917 \ldots \ldots$ & 8.0 & 7.5 & 7.2 & 9.0 & 7.0 & 8.5 & 6.8 \\
\hline $1916 \ldots \ldots$ & 6.0 & 5.2 & 3.8 & 7.3 & 4.5 & 11.9 & 5.0 \\
\hline $\begin{array}{l}1914 \ldots . . . \\
\text { SOUTH } \\
\text { DAKOTA }\end{array}$ & 14.9 & 12.1 & 10.3 & 13.9 & 10.9 & 13.7 & 10.8 \\
\hline 1917 & 15.3 & 13.1 & 11.1 & 15.6 & 10.0 & 14.0 & $\cdots$ \\
\hline $1916 \ldots \ldots$ & 7.9 & 6.2 & 5.0 & 8.2 & 5.0 & 18.5 & $\cdots$ \\
\hline $\begin{array}{l}1914 \ldots \\
\text { MON- } \\
\text { TANA }\end{array}$ & 11.2 & 9.3 & 7.5 & 11.2 & 9.3 & 14.0 & 8.7 \\
\hline $1917 \ldots \ldots$ & 9.3 & 7.5 & 6.5 & 9.0 & 7.5 & 12.5 & 7.5 \\
\hline
\end{tabular}

65 Monthly Crop Report, August, 1918, Washington, p. 95. 
While looking through the Table, the reader should bear in mind the relative contribution which each variety of wheat makes to the total crop. This has already been pointed out in a previous Section. ${ }^{66}$ The reader will remember that most of the wheat produced in the four chief spring-wheat States consists of spring varieties of Common Wheat, i. e., Marquis, Velvet Chaff, Bluestem and Fife; that Durum wheat in 1917 formed 25 per cent. of the total wheat crop in North Dakota, 20 per cent. in South Dakota, 8 per cent. in Montana, and 3 per cent. in Minnesota; and that Winter wheat in 1917 formed 40 per cent. of the total crop in Montana, but only 3 per cent. in Minnesota and South Dakota, and only 1 per cent. in North Dakota.

The most important conclusion to be drawn from the Table is that in each of the four great spring-wheat States, Minnesota, North Dakota, South Dakota, and Montana, Marquis has outyielded every other spring variety of Comman Wheat, i. e., Velvet Chaff, Bluestem, and Fife. Velvet Chaff was outrielded by from 0.5 to 3.6, Bluestem by 0.8 to 5.5 , and Fife by 1.0 to 5.3 bushels per acre.

Marquis, on the average for all the years given in the Table and throughout the whole spring-wheat region of Minnesota, the two Dakotas, and Montana, has outyielded Telvet Chaff by 1.8, Fife by 2.7, and Bluestem by 3.3 bushels per acre.

It is not without interest to observe how Marquis has fared, on an average of three vears, in each of the three chief spring-wheat States taken individually.

In Minnesota, Marquis has ontyielded Velvet Chaff by 2, Fife by 2.9, and Bluestem by 3.9 bushels per acre.

In North Dakota, Marquis has ontyielded Telvet Chaff

B6 Section VII on The Introduction of Marquis into the United States. 
by 1.4 , Fife by 2.2 , and Bluestem by 2.5 bushels per acre.

In South Dakota, Marquis has outyielded Velvet Chaff by 1.9 , Fife by 3.7 , and Bluestem by 3.6 bushels per acre.

In MIontana, where we have data for one year only, Marquis has outyielded Velvet Chaff by 1.8, Fife also by 1.8 , and Bluestem by 2.8 bushels per acre.

So far as Durum is concerned, Marquis has outyielded this variety in Minnesota by 1.6 , and in Montana by 0.3 bushels per acre; but Durum has outyielded Marquis in North Dakota by 0.4 , and in South Dakota by 0.2 bushels per acre.

Winter wheat, on the relatively few acres where it has been grown successfully, has outyielded Marquis in each of the four States: in Minnesota by 4.2, in North Dakota by 1.7 , in South Dakota by 4, and in Montana by 3.2 bushels per acre.

From the point of riew of the three older spring varieties of Common Wheat, we can make the following statements:

Bluestem was outyielded by Marquis: in Minnesota by 3.9, in North Dakota by 2.5, in South Dakota by 3.6, and in Montana by 2.8 bushels per acre. In other words, Marquis outyielded Bluestem, on the average throughout the spring-wheat region, by from 2.5 to 3.9 , or more exactly by 3.3 bushels per acre.

Fife was outyielded by Marquis: in Minnesota by 2.9, in North Dakota by 2.2, in South Dakota by 3.7, and in Montana by 1.8 bushels per acre. In other words Marquis outyielded Fife, on the average throughout the springwheat region, by from 1.8 to 3.7 , or more exactly by 2.7 bushels per acre.

Velvet Chaff was outyielded by Marquis: in Minnesota by 2 , in North Dakota by 1.4, in South Dakota by 1.9, and in Montana by 1.8 bushels per acre. In other words, Mar- 
quis outyielded Velvet Chaff, on the average throughout the spring-wheat region, by from 1.4 to 2 , or more exactly by 1.8 bushels per acre.

The superior productiveness of Marquis entails increased farm values of the wheat crop. A recognition of this fact, no doubt, has been largely responsible for the rapid rise of the new variety into favor with farmers during the past four years, and for the corresponding diminution in the cultivation of Velvet Chaff, Bluestem, and Fife.

In concluding this Section, we may compare the relative yields of Marquis and Fife in the United States and Canada. It will be remembered that it was found in longperiod tests that Marquis outyielded Red Fife: at Indian Head in Saskatchewan by almost 40 per cent., and at Brandon in Manitoba by over 20 per cent. ${ }^{67}$ A calculation made from the Table shows that, as an average for three years, Marquis outyielded Fife: in South Dakota by 41 per cent., in North Dakota by 29 per cent., in Montana by 24 per cent., and in Minnesota by 13 per cent. It thus becomes obvious that the advantage of replacing Red Fifo by Marquis is nearly equal in the two countries.

\section{The Favorable Grading of Marquis}

As a rule, but especially in unfavorable seasons, the increased yield of Marquis over Red Fife on summer fallow is associated with a higher weight per measured bushel and a greater plumpness of kernel. Consequently Marquis tends to obtain a higher grade than Red Fife. This often results in a considerable difference in price apart from the difference in yield. If, for instance, Red Fife were to produce 20 bushels to the acre grading No. 4 and Marquis 25 bushels grading No. 2, the difference in value would be greater than 25 per cent. in favor of Mar67 Vide Section $\mathrm{X}$ on Long-period Tests for Earliness and Yield. 
quis by reason of the higher price paid for the higher grade. Of course the higher grading of IIarquis relatively to the higher yield is but a small matter; but supposing $80,000,000$ bushels of Marquis, on account of higher grading, were to fetch on the average 3 cents per bushel more than a similar quantity of Red Fife, the gain due to the more favorable grading would be $\$ 2,+00,000$, a sum with a purchasing power by no means to be despised.

\section{Resistance to Shelling}

Marquis does not shell, i. e., drop a certain proportion of its grains just before it is cut like Bluestem, Red Fife, Preston, and certain other kinds of wheat. But this advantage which has been especially noted in North Dakota upon the windy prairie and in some parts of Saskatchewan, Alberta and Manitoba, brings with it a disadvantage, for Marquis requires extra power in threshing. A thresher must take care that his machine is accurately set, otherwise much of the wheat may be lost as the straw is run through into the straw stack. The loss due to shelling in Bluestem in North Dakota often amounts to a bushel per acre and possibly more in years of rapid ripening. In some years, when Bluestem is harvested, the ground is littered with the grains shattered out of their glumes by the wind and the harvesting machinery. The amount of grain left upon the ground, and therefore irrecoverable, not infrequently appears to be equal to the amount originally used as seed. ${ }^{68}$ Red Fife does not shell so badly as Bluestem but, nevertheless, is far from equaling Marquis in the retention of its grains. Resistance to shelling by Marquis is undoubtedly one of the several factors which favor a high yield from this variety of wheat.

68 The facts concerning the shelling of Bluestem in North Dakota were kindly supplied to me by Professor H. L. Bolley. 


\section{Milling and Baking Qualities}

It is very important that western Canada should continue to raise wheat which, like Red Fife, possesses very high milling and baking qualities; for it is upon these qualities that the intrinsic value of wheat chiefly depends. The grading of wheat for sale is based as closely as possible upon the value that the cereal will have for the miller and the baker; and those wheats which most nearly approach their ideal, are placed in the highest grades and command the best prices in the open market.

Quality in wheat is a very complex thing; and, when it is necessary to measure it, a number of more or less independent factors must be considered. These factors were discussed by Dr. Charles Saunders in a very exhaustive and masterly manner in a Central Experimental Farm bulletin ${ }^{69}$ published in the year 1907 , and they have recently been summarized by Professor C. H. Bailey, who is a cereal technologist, as follows: ${ }^{70}$

(1) Relative plumpness of the kernets, which influences the yield or percentage of flour which can be produced from the grain.

(2) Density of the kernels, which also affects the yield of flour, since, other things being equal, a larger proportion of the endosperm or "floury" portion of the kernel can be separated as flour when it is hard or vitreous in texture rather than soft or "starchy."

(3) Moisture content of the grain, which affects its keeping qualities, ease of milling, and losses which occur through evaporation during the process of milling.

69 Charles E. Saunders, Quality in Wheat, Bulletin No. 57, Central Experimental Farm, Ottawa, pp. 6-28.

$70 \mathrm{C}$. H. Bailey, Marquis Wheat; II, Milling Quality, Bulletin No. 137, Minnesota Wheat Investigations, Series II, University Farm, St. Paul, 1914, p. 10. 
(4) Soundness of the grain, as indicating its freedom from fermentative changes.

(5) Baking strength of the flour, or its ability to produce a large, well-raised loaf of bread. The relative strength of flour is influenced by at least two groups of factors: (a) The percentage and physical properties of the two principal proteins of wheat flour, known collectively as gluten, and (b) the quantity and nature of the yeast food originally present in the flour and formed during the process of fermentation.

(6) Absorption, or percentage of water necessary to make a dough of proper consistency from the flour in breadmaking, since the more water that can be employed per unit of flour, the greater the weight of bread which can be produced from it.

(7) The color of the flour, the demand being for a very white product. ${ }^{71}$

Factors (3) and (4), the moisture content and the soundness of the grain, are controlled almost entirely by the method of curing and handling the grain after it is harvested and are not affected by varietal characteristics. When Dr. Saunders was re-selecting all the mixed wheats which came into his hands at Ottawa and the progeny of numerous crosses which he made in 1903 and in subsequent years, he had to pay particular attention to the plumpness and hardness of the kernels as influencing the flour yield, and to the gluten content and general baking qualities of the flour, including baking strength, absorp-

71 Professor Bailey also points out that the quality of any wheat is influenced not only by its varietal characteristics but also by the soil and climatic conditions under which it is grown. Thus the protein content and baking strength will almost invariably be lower when the wheat is grown in a moist soil than when it is produced under arid conditions. On the other hand, unfavorable conditions, such as drought, rust, and hot winds, will result in more or less shriveled grain giving lower flour yields when milled. 
tion and color. In doing this, his University training in chemistry stood him in good stead. One of the most remarkable features of the work of Dr. Saunders is that he not only crosses wheats, selects their progeny, propagates the selections on plots and in fields, and records all their field characteristics such as yield and earliness, but that he also carries out all the needful baking and milling tests himself in his own laboratory.

British millers demand from Canada hard red spring wheat which shall produce flour which shall not only be white and have good absorption but which shall have the highest possible baking strength. The strong Canadian flour is perhaps not the best for making loaves with directly, so far as the consumer is concerned, but it is invaluable for mixing purposes. The British miller has plenty of soft wheat at his disposal and thus can readily obtain an abundance of flour which is relatively weak. He therefore mixes the strong Canadian flour with the weaker flour from soft wheats and thus produces a standard flour of his own design. On account of there being much more soft wheat for sale than hard wheat, the latter, in accordance with the law of supply and demand, naturally fetches the higher price. There is, therefore, a very good reason why the Red Fife and Marquis wheat of western Canada, which produce flour of the rery highest baking strength, should be so much sought for in the British market.

From the first, when selecting new wheats, Dr. Saunders bore the requirements of the British market in mind; and he determined never to send out from Ottawa to the farmers of the West, for general cultivation, any new variety of wheat which would be inferior to Red Fife in its milling and baking qualities. This, of course, led to scores of rejections of otherwise promising varieties, and 


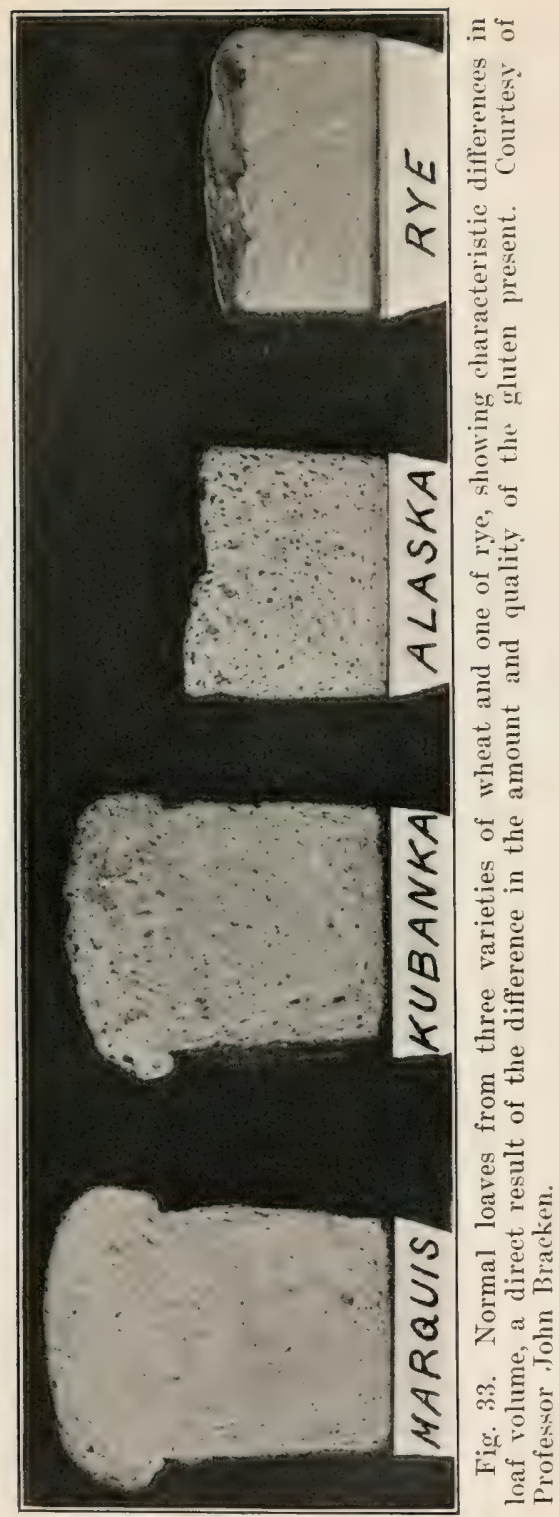




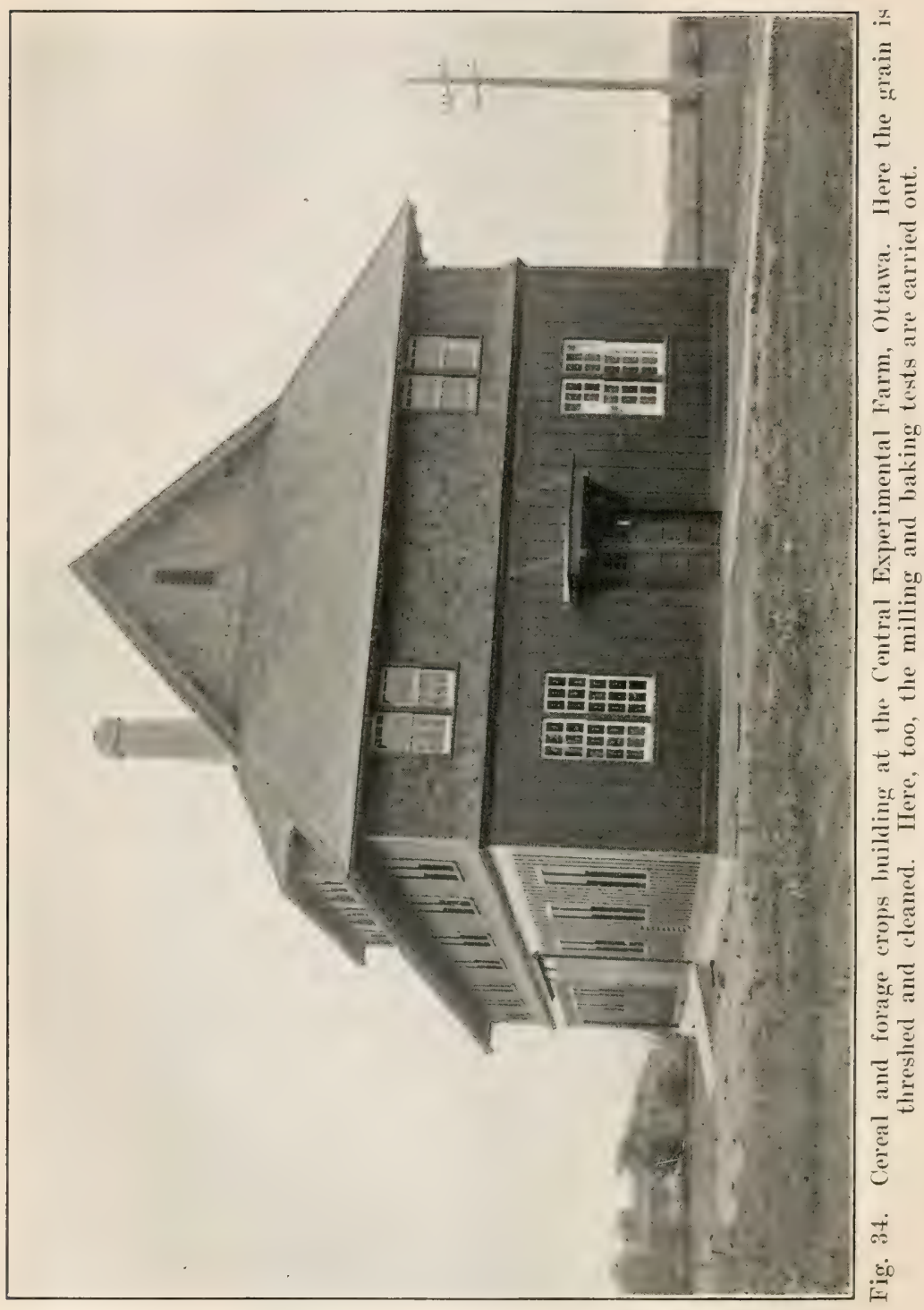


no one of his selections to which he attaches any value has failed to pass the most rigorous milling and baking tests. That Marquis gives so much satisfaction to millers and bakers is therefore not due to any accident but to the careful work of Dr. Saunders who, as the first miller and the first baker of the new wheat, appreciated the good qualities of its flour several years before it became an article of commerce.

When beginning the task of re-selecting all the more or less mixed wheats assembled at Ottawa in 1903, which led to the discovery of Marquis, Dr. Saunders had not a mill, or a fermenting cupboard, or an oven in his laboratory; and, in the absence of this apparatus, he judged the quality of the wheat flour from his different wheat plants by means of the chewing test. In the art of applying this test he soon became a veritable master, and thereby considerably hastened the work of selection. It had long been known to practical wheat buyers that some rough idea of the baking strength of flour can be obtained by chewing for about four or five minutes a few kernels of the wheat from which the flour is to be made, and by then examining in the fingers the elasticity of the little pellet of gluten taken from the mouth. Dr. Saunders, after carrying out this simple test for a large number of times, found that it was thereby possible to acquire considerable facility for judging flour quality, and since then he has used the test extensively. To obtain sufficient gluten for a test, he usually chewed about ten or a dozen kernels from the crop of each individual plant which was being considered as a possible progenitor of a new variety of wheat. He found it to be a general rule that the strongest flour is obtained from those wheats which produce gluten having the greatest ability to recover its shape. ${ }^{72}$

72 Charles E. Saunders, loc. cit., p. 9. 
In discussing the chewing test, Dr. Saunders says: "The variations in the quality of the gluten observed in different plants of the same pedigree are often very great, and it is not claiming too much to say that this simple and apparently inefficient method of testing enables one to select with a fair degree of certainty a few of the best plants each season, and this enormously reduces the labor which would otherwise be involved in multiplying a large number of strains, most of which would ultimately be rejected. That this crude method of testing is infallible, one cannot maintain. The writer has shown, however, by actual baking trials that it possesses sufficient accuracy to be worthy of the very serious attention of all wheat-breeders, although an investigator may have to perform the test sereral hundreds of times before acquiring any proficiency in it. It is not really a very difficult matter to judge in this way, as a rule with fair accuracy, both the gluten strength and the color of the flour which would be produced from the wheat in question; and, if time were taken to weigh the wheat used and the globule of gluten produced, it would certainly be possible to form a rough estimate of the proportion of gluten which the wheat would yield. The writer does not know whether this method of judging the quality of individual plants has been used by other investigators or not, but he would strongly recommend it as imperatively necessary for any one attempting to breed wheat for high quality. It requires some patience and a fairly good set of teeth, but these two attributes can be considered essential to all breeders of wheat. A study of the later sections of this bulletin will make it clear to any one that the usual observations on the color and hardness of the kernels are almost useless for estimating flour strength in breeding new wheats. The chewing test is certainly of great value although it should always be confirmed by 


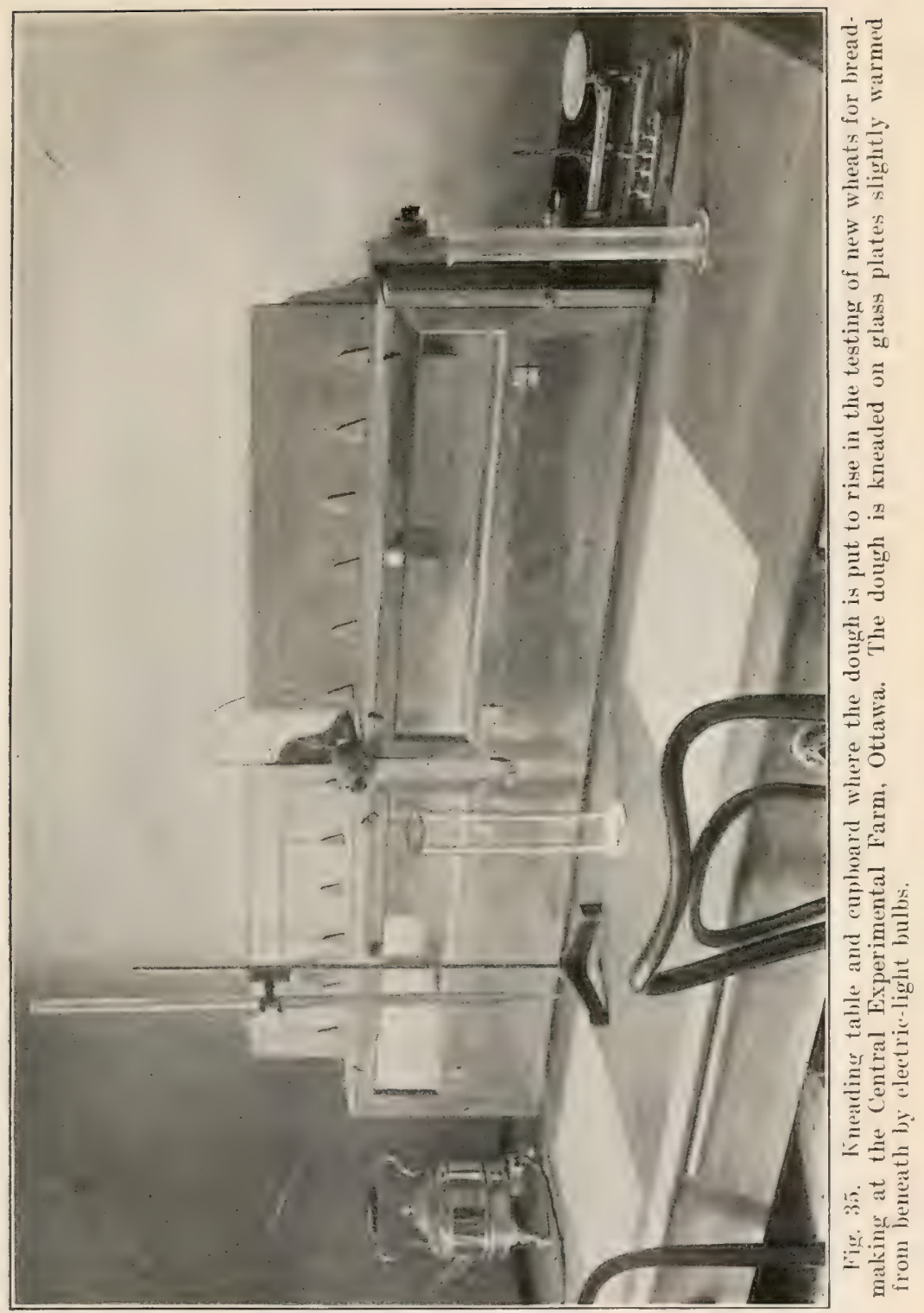



actual baking trials as soon as sufficient wheat is obtainable for that purpose."

Dr. Saunders' application of the chewing test has a definite historical importance, for he thereby obtained the clew to the excellent milling and baking qualities of Marquis wheat. He selected the first head of Marquis in 1903 because, in addition to having other good qualities, it passed this test. The progeny of the first head of Marquis successfully withstood the chewing test in 1904 and 1905 ; and it was not until the close of this period that, having set up a small experimental mill, a fermenting cupboard, and an oven in his laboratory, Dr. Saunders was able to grind the wheat into flour and bake the dough into bread in the usual manner. Rigorous milling and baking tests made with the new apparatus completely confirmed the judgment of Marquis which he had made three seasons previously from the examination of the little gluten pellets taken from his mouth.

Marquis wheat, since being generally introduced into Canada and the United States, has been subjected to a great number of tests for its milling and baking qualities in the laboratories of cerealists and millers; and everywhere it has been pronounced to be, as regards these qualities, a first-class wheat.

Comparative milling and baking experiments made with Marquis and other standard varieties of hard spring wheat were carried out by Professor Ladd ${ }^{73}$ of the North Dakota Agricultural Experiment Station in the years 1913 and 1914, and by Professor Bailey ${ }^{74}$ of the Minnesota

${ }^{73}$ E. F. Ladd, Chemical and Physical Constants for Wheat and Mill Products, N. Dakota Agr. Exp. Sta., Bulletin No. 114, 1916, pp. $273-297$.

74 C. H. Bailey, Marquis Wheat, II, The Milling Quality of Marquis Wheat, Minn. Agr. Exp. Sta., Bulletin No. 137, 1914, pp. 9-14. 
Agricultural Experimental Station in 1913, and the results have been summarized by Messrs. Ball and Clark ${ }^{75}$ as follows:

"The published data show that the Marquis wheat samples tested were equal or slightly superior in most respects to the samples of Fife, Bluestem, and Preston (Velvet Chaff) wheats raised under similar conditions. A higher total yield of flour was obtained from the Marquis. The percentage of bran was less, while that of shorts was greater from the Marquis than from the three standard groups of spring common wheats. Compared with durum wheat, the Marquis is slightly lower in yield of flour and shorts but higher in yield of bran.

"The baking quality of Marquis flour is high. It contains more crude protein than the flours of the three principal groups of spring common wheat. The amount of water absorbed by the Marquis flour in dough making also is high. These are important features in determining the expansive quality of the flour or its gluten. The loaf volume of the Marquis exceeds that of the other hard spring common wheats. There is comparatively little difference in the color, texture, and crumb of the Marquis and of the other spring common wheats.

"In short the data show the Marquis to be a first-class milling wheat."

\section{The Origin of Hard Red Calcutta}

Hard Red Calcutta, the female parent of Marquis, is a wheat which was imported into Canada by Dr. William Saunders some thirty years ago for experimental purposes. It was grown in plots at the Central Experimen$11{ }_{75}$ C. R. Ball and J. A. Clark, Experiments with Marquis Wheat. Bulletin No. 400, Bureau of Plant Industry, U. S. Department of Agriculture, Washington, 1916, p. 40. 
tal Farm and at the branch farms, and a certain number of samples were sent out for trial to farmers and experimentalists in various places. Twenty-seven such samples were distributed from Ottawa in $1892,{ }^{76}$ but for various reasons, particularly on account of its small yield and very short straw, the Indian wheat has not proved a success under Canadian conditions. ${ }^{\mathbf{7 7}}$

Hard Red Calcutta, when grown in Canada, was found to ripen exceedingly early in the season, some two or three weeks earlier than Red Fife; but, unfortunately, linked with this very desirable character were others which were very undesirable, the chief being a poor yield, very short straw, the shattering of the grains from their glumes when ripe, and the bearded condition of the heads.

The newly imported Indian wheat was crossed with Red Fife in 1892 with the hope of obtaining a wheat like Red Fife but which would ripen much earlier in the season than the standard variety. ${ }^{78}$ The progeny of the cross included types with short straw, with long straw, and with medium straw; types with short heads, long heads and intermediate heads; types with the early-ripening habit, the late-ripening habit; and so forth. From all these types were selected a few which most nearly resembled Red Fife in general appearance but which possessed the early-ripening habit; and it was the best one of these few which was subsequently named and introduced as Marquis.

Under what circumstances Hard Red Calcutta came into existence in India is unknown to the writer. It is very probable that its origin, like that of so many other

76 Experimental Farms Reports for 1902, p. 14.

77 S. A. Bedford in a report on wheats grown at Brandon Experimental Farm in 1891, Experimental Farms Reports for 1901, p. 249.

78 See Section II on: The Seleotion of Marquis by Dr. Charles E. Baunders. 
cereals, has never been accurately recorded. Hard Red Calcutta, as already pointed out in an earlier Section, ${ }^{79}$ is a commercial expression and includes several different types of wheat. Thus, for instance, there is Hard Red Calcutta with white chaff, Hard Red Calcutta with brown chaff, and Hard Red Calcutta with black chaff, these types breeding true and being quite distinct from one another. All these types originated in India but how and where are not known. One of them, but which one is also not known, was chosen as the female parent in the cross from which Marquis originated.

\section{The Origin of Red Fife}

The story of the introduction of the celebrated wheat generally known as Red Fife or Scotch Fife into North America, is fraught with the elements of romance and has exercised the mythopœic faculty of those who have handed it down to us. To relate it here harmonizes well with our main theme, for, as we have scen, Red Fife is the male parent of Marquis.

Red Fife is called Red because its grains, when typically developed, are of a good red color, and Fife after David Fife, an Ontario farmer, who was the first to raise Red Fife on this side of the $\Lambda$ tlantic, and who introduced this variety into Canadian agriculture almost eighty years ago.

J. W. Clarke, a Wisconsin farmer, had an excellent crop of Red Fife upon his farm in the year 1860. His yield averaged 36 bushels per acre, and so pleased was he with his harvest that he wrote a letter to the Country Gentleman and Cultivator telling of his experiences and recommending the new variety of wheat to agriculturists in general. Incidentally, he referred to the originator of Red ${ }^{79}$ Section II. 
Fife as being David Fife of Otonabee in what was then called Canada West but now Ontario. ${ }^{80}$

Clarke's letter naturally attracted attention in Canada, and in March, 1861, it was reproduced in the Canadian Agriculturalist. Accompanying the first letter, however, was a second, written by George Essen, in which the main facts relating to the introduction of Red Fife in Canada were recorded for the first time and by an eye-witness. George Essen was one of David Fife's neighbors. Moreover, the Fifes and Essens had both come from the Kincardine parish of Tullyallen in Scotland, and, as pioneers, had settled together at Otonabee, Peterborough County, Ontario. It is very evident, therefore, that George Essen was in a particularly good position to know the true facts concerning the introduction of the new wheat which was becoming so famous. Essen's letter was as follows:

"About the year 1842 David Fife of the township of Otonabee, Canada West (now Ontario), procured through a friend in Glasgow, Scotland, a quantity of wheat which had been obtained from a eargo direct from Danzig. As it came to hand just before spring seed-time, and not knowing whether it was a fall or spring variety, IIr. Fife concluded to sow part of it that spring and wait for the result. It proved to be a fall wheat as it never ripened, except three ears which grew apparently from a single grain. These were preserved, and although sown the next year under very unfavorable circumstances, being quite late and in a shady place, it proved at harvest entirely free from rust, when all the wheat in the neighborhood was badly rusted. The produce of this was carefully preserved, and from it sprang the variety of wheat known over Canada and the Northern States by the different names of Fife, Scotch, and Glasgow. As the facts occurred in my imme-

so The Country Gentleman and Cultivator, October, 1860. 
diate neighborhood and being intimately acquainted, not only with the introducer, but with the circumstances, I can vouch for the correctness of the statement and, if necessary, produce incontestible proof." 81

This letter seems to afford conclusive evidence that the wheat from which Red Fife sprang was formerly grown in central or eastern Europe, that it was conveyed by ship from the port of Danzig to the port of Glasgow, and that at the latter place a sample of it was procured from the cargo and sent to David Fife in Ontario. There is therefore no reason whatever to suppose that Red Fife, as its synonyms Scotch Fife and Glasgow seem to suggest, was ever grown in Scotland.

There were some who were inclined to believe that Red Fife originated as a sport from David Fife's imported seed and therefore that it constituted a new variety which first came into existence in Ontario. This hypothesis, which was never very satisfactory, has now been shown by Dr. Saunders to be superfluous, for he has demonstrated by exact comparison that Red Fife is identical with a central European variety of wheat known as Galician.

In his evidence, given as Dominion Cerealist before the Committee on Agriculture at Ottawa in 1905, Dr. Charles Saunders, after quoting George Essen's letter, made the following statements: "This account has given rise to the idea that Red Fife is a Canadian wheat, that it originated with Mr. Fife in some wholly unaccountable manner, or as a sport from a European variety. It always scemed to me probable that the kernel which Mr. Fife obtained was merely a seed of some common European variety which had found its way into the wheat from Danzig.

81 The Canadian Agriculturalist, March, 1861, p. 167. The letters of Clarke and Essen are here cited from an article Canadian Wheat History prepared by C. C. James and published in the Grain Growers' Guide, June 7, 1916, p. 36. 
Last season, among our newly-imported European varieties, was one under the name of 'Galician,' obtained from a seedsman in Germany. Now, Galicia lies about 300 miles inland from Danzig. This imported Galician wheat struck me at once as being very much like Red Fife, and I therefore sowed it last spring alongside Red Fife, and watched them both very carefully throughout the season. They proved to be identical at all stages of their growth as well as when the grain was harvested. A larger plot of Galician wheat furnished grain for milling purposes. This was ground, analyzed and baked. Red Fife from a plot in the same field was similarly treated. The two samples of flour were found to be alike in all respects, and thus the absolute identity of the two wheats was established. The firm from which the seed of the Galician wheat was obtained, informed me that the variety was procured by them many years ago from a farmer in Galicia. It seems, therefore, quite clear that the kernel of wheat which came into the hands of Mr. Fife, was a kernel of this Galician spring wheat, accidentally present in the cargo of winter wheat from Danzig, of which he obtained a portion. It is interesting to be able to throw this light on the subject of the origin of Red Fife, which has hitherto seemed very dark. There is no doubt that this variety is still grown in Europe, and so far as our tests have gone, it seems to be of the same quality there as it is here." 82

It therefore seems certain: that Red Fife was originally grown in mid-Europe; that one of its kernels was conveyed in a cargo of winter wheat, via the Baltic and the North Sea, from Danzig to Glasgow; that a sample of the cargo containing the kernel in question was procured by

82 The Origin of Red Fife Theat, Evidence of Dr. Charles E. Saunders before the Select Standing Committee on Agriculture and Colonization, Ottawa, 1905, pp. 216-217. 
some one at the Scottish port; that this sample was sent to David Fife at his farm in Ontario about the year 1842; that this single kernel germinated and produced a plant with three heads; that the kernels of these three heads, when sown the next year, gave rise to the wheat which became known as Red Fife; and that Red Fife is identical with a wheat known as Galician which was recently in cultivation in Galicia.

George Essen's letter was but little noticed at the time it was written and soon passed into oblivion. As Red Fife grew in importance with the passage of years, the story of its origin became a tradition which, as it passed from mouth to mouth, gradually assumed varied and colorful forms. Some of these traditions which deal chiefly with the manner in which the original sample of grain was first procured, will now be told.

A contributor ${ }^{83}$ to the Manitoba Daity Free Press, writing in 1883 in reference to Red Fife, says: "The first wheat grown in Canada was on a farm owned by a person by the name of Fyfe in the township of Otonabee, County of Peterborough. Mr. Fyfe hired a Scotchman as a farm laborer. When his time expired with Mr. Fyfe, he decided on returning to his native country. Mr. Fyfe requested him to send a Scotch bonnet from Glasgow. When there a vessel from the Black Sea was unloading wheat at one of the docks. ${ }^{84}$ He procured the full of the bonnet and sent it on the first opportunity to Mr. Fyfe. I have many times been on the same farm."

Another tradition, current at Peterborough at the present day, also includes the incident of the cap but with different details. It is as follows: "David Fife did not

83 M. Colquhoun of Mansfield, Ontario, in the Manitoba Daily Free Press, Feb. 24, 1883, p. 8.

84 In this story the Black Sea is substituted for Danzig on the Baltic. This is doubtless an error due to imperfect memory. 
send for the seed. An acquaintance, strolling along the dock at Glasgow, found men unloading wheat. He knew that Fife had emigrated to Canada, and he also knew of a mutual friend who proposed to go out to the new country presently. The thought struck him to take a sample of the wheat which to his observation looked very good, and send it to Fife. He had nothing in which to hold the wheat, but there was a hole in the lining of his cap. He opened the lining at the hole, filled in a handful, and afterwards wrapped it up in paper. Fife received the seed and planted it. It all grew but rusted badly, except five heads, all from one stalk or root. Two of these heads were eaten by oxen leaving only three heads. The great probability is that the single grain from which the three heads grew was an accidental hybrid." 85

The incident about the oxen has been connected with David Fife's wife and in this form is told as follows: "Mrs. Fife is entitled to share in her husband's honor, for, discovering the family cow contentedly making a meal of the growing clump of grain, she was in time to rescue a portion of it before it was too late." 86 It may be added that a photograph of Mr. and Mrs. Fife was taken when they were very advanced in years and was reproduced in several newspapers.

Another tradition ${ }^{87}$ introduces a sack: David Fife "having by experiment found that the Scotch Danzig wheat was a spring and not a winter variety, the sack in which the wheat had been contained was looked up and a

85 This tradition was told to Mr. F. H. Dobbin of Peterborough, who kindly wrote it down and sent it to me in August, 1918. Mr. Dobbin, in his letter to the author stated that he was assured by one who knew all the circumstances that this tradition is the correct one as opposed to another about to be related.

86 C. C. James, Canadian Wheat History, Grain Growers' Guide, June 7, 1916, p. 36.

87 Ibid. 
handful of the grain was sown in the succeeding year." If this story were true, and the writer, in view of George Essen's letter is not prepared to accept it as such, we should be obliged to regard Red Fife as having sprung not from a single plant but from many scores of plants, thus having a multiple origin.

In the first two of the traditions which have been related so far, David Fife is represented as not sending for the wheat but as receiving it as an unexpected present from a friend in Scotland. Another tradition which is told at much greater length and with many details not appearing elsewhere, and which is regarded by Mr. F. H. Dobbin, the present town-clerk of Peterborough, as authentic, has a very different complexion, for it represents Fife as a man who was anxious to raise a better kind of wheat than was locally available and who therefore sent to Scotland on two occasions for foreign seed-wheat for experimental purposes. The story ${ }^{88}$ told by Mr. Dobbin is as follows:

"The locality in which the celebrated Fife Wheat was first propagated, is that which is now known as the Midland District of Ontario. This part of the province lies midway between Toronto and Kingston, skirts Lake Ontario, extends back from the Lake for a distance of forty miles, and comprises in part the counties of Durham, Northumberland, Peterborough, and Hastings.

"The township of Otonabee, in which the Fife family lived, forms the most southern part of the county of Peterborough, and is bounded on the west by the river Otonabee, on the south by Rice Lake, on the north by the townships immediately adjoining, and on the east by the county of IIastings. At the time of which we are speaking, all this section of the country was comprised in what was known

88 This story was kindly sent to me in August, 1918, by Mr. Dobbin, to whom $I$ applied for information. 
as the Colborne District, and was represented as a municipal unit in the Old House of Assembly of Upper Canada. The Township of Otonabee was one of the first to be settled, men going into its forests as early as 1816. So, when the Fife family reached Canada and directed their steps to Otonabee as their future home, settlers were already in possession of farm lands and many locations had been procured from the Crown. The Fife farm is situated about seven miles from the city of Peterborough.

"The late David Fife, the subject of this memoir, settled in Otonabee in the early thirties of the last century. For several years after that time, the wheat in general sowing in the locality was a fall wheat of a brand known as Siberian. This had come into favor largely owing to the fact that those who sold it as seed claimed that it was particularly fitted to survive the rigors of a Canadian winter. However, Siberian was found to exhibit a weakness in that it often became rusted badly with a consequent diminution in the crop. Fife, being desirous of obtaining improved seed, sent to Glasgow for samples. These were forwarded, but arriving in Canada late in the season, were held in storage at Smith's Creek on the lake front until the following spring. Smith's Creek is now known as Port Hope. The samples cost, in money as now we count it, about three dollars per bushel and a considerable sum for storage. The seed was sown but never sprouted. ${ }^{89}$

"In 1841 Fife again became interested in importing seed-wheat and wrote to a personal friend named Strothers who was a clerk in a grain store in Glasgow, asking that samples of a well-recommended Russian wheat be procured and forwarded. Mr. Strothers selected a new kind,

89 According to Essen's letter the fall wheat germinated but did not ripen. The earlier account written in 1861 is probably the correct one. 
brought from Danzig by ship, and sent it on, saying that from what he had learned from the importers the seed would answer Fife's requirements. Two lots of wheat were sent, one for fall and one for spring sowing.

"The second shipment was held at Cobourg during the fall and winter, as before. Both lots of wheat were sown in the following spring but the fall wheat never germinated. The spring wheat grew, developed, and ripened. In growth and appearance it proved to be superior to any other wheat in the neighborhood, but only three heads were saved. It is known that the seed was not sown until all the other kinds of grain were above the ground, as Fife was ill and wished to watch the sowing and the cultivation himself. The new variety, to the surprise of all, was absolutely free from rust. ${ }^{90}$

"The crop was gathered by Mr. Fife and carefully stored. A pint of seed was realized which, on being sown early the next year, produced a half-bushel at harvest time. From this limited quantity of seed the neighborhood was supplied with samples for trial, and so successful was the result that the district benefited largely from the Fife wheat.

"The spring following, this would be about 1843, a man named Henderson bought from Fife one bushel and from this as seed reaped nearly three hundred bushels, ${ }^{91}$

90 Red Fife wheat is not rust-resistant but often rusts badly. Essen's and Dobbin's accounts agree in stating that the first crop was free from rust when the other wheat suffered severely from the disease. This may be due to the fact that the seed was sown in a protected place and not in an open field. Essen says the seed was sown "quite late and in a shady place."

$91 \mathrm{As}$ a story is told, errors are apt to be introduced where figures are quoted. It takes more than a bushel to sow a single acre, and 50 bushels to an acre is an excellent crop. No one ever yet obtained 300 bushels to an acre, so that Mr. Dobbin's figures here must be fallacious. Such a erop might have come from ten bushels of seed 
a part of which he disposed of at $\$ 3.00$ per bushel, erroneously naming it Glasgow Wheat. The parent seed never grew in Scotland but was imported from one of the Russian districts by ship. Efforts made to locate the territory from which the seed was derived were never successful, and the origin of the new wheat was looked upon as an accidental occurrence. From these small beginnings came the wheat that has so largely contributed to the agricultural reputation of this section of Ontario, and which has made the crops desirable to millers all over Canada."

Such, then, are the traditions of Red Fife which have come down to us. All of them doubtless contain some truth, but to what extent certain of the more picturesque details have been unconsciously invented it is at present difficult or impossible to sav. It may be that David Fife's correspondence with his friend in Scotland and with his neighbors is still in the possession of his descendants. If it could be found it would doubtless throw a new and very interesting light upon the history of the wheat with which the family name of Fife is so honorably associated.

In Ontario, about the year 1870, spring wheat formed about 60 per cent. of the total crop, and the chief variety of spring wheat grown was Red Fife. ${ }^{92}$ Red Fife, after its successful introduction in Ontario, soon passed into the United States; and, as we have seen, an excellent crop of it was raised by a Wisconsin farmer in 1860. With the development of the wheat lands in the Great Plains region, Red Fife was introduced into Minnesota and the two Dakotas.

but not from one. In the preceding paragraph a pint of seed is said to have been realized from the three heads. This is another impossibility. Possibly the original statement was "less than a pint."

92 Spring Wheat in Ontario, Manitoba Daily Free Press, March 16, 1883 , p. 7. 
Exactly when Red Fife was first sown in western Canada is unknown; but a certain small amount was doubtless being grown in Manitoba as early as about 1870 . This seems to follow from the fact that in 1876 nearly one thousand bushels of Red Fife were exported from Manitoba to Ontario to re-seed the very province in which this variety of wheat had originated. The account of this remarkable transaction is related by C. C. James ${ }^{93}$ as follows: "In 1876 spring wheat failed in Ontario, the old reliable Red Fife apparently had run out, it had lost its vigor - perhaps the fault lay in the soil rather than in the grain. The Red River Fife wheat had made a reputation, and so in the fall of the year the late R. C. Steele of Steele Brothers, Toronto, started for Manitoba. He traveled by rail to St. Paul and thence to Fisher's Landing, where, doubtful of the river navigation so late in the year, he took a lumber wagon and made the 150 miles to Winnipeg in 30 hours of continuous going. He wished to bring back 5,000 bushels, but all that he was able to secure at Winnipeg was 857 bushels, which he bought at 85 cents a bushel. This wheat came down to Toronto by steamer from Winnipeg to Fisher's Landing where he secured some additional United States wheat, thence by rail to Duluth, by vessel from Duluth to Sarnia, and by rail from Sarnia to Toronto. This was the first wheat exported from Manitoba to the East. It was in the latter part of 1876 . Mr. Steele paid 85 cents per bushel for this wheat on October 12, 1876."

In Manitoba, up to about the year 1882, the amount of wheat grown in the province had been scarcely more than sufficient to supply the local market. However, with the

93 C. C. James, Canadian Wheat History, Grain Growers' Guide, Winnipeg, June 7, 1916, p. 36. 
opening of the first railway in the province in 1878 giving direct access to St. Paul from St. Boniface, and with the prospect of the completion of the Canadian Pacific Railway which would connect the prairie with eastern ocean ports, grain dealers, farmers, and railway men became convinced that a great export trade in wheat would soon be developed in the Canadian West. In 1883, therefore, by which time the introduction of the purifier into flour mills had greatly enhanced the value of hard spring wheats, an effort was made to improve the quality of the crops. To this end a large amount of Red Fife was brought into Manitoba from Minnesota.

In 1882, James Hartney imported into Manitoba from Minnesota a car-load of Red Fife. He sowed it on virgin land and it produced a splendid crop. Some of the grain was shown at an exhibition held in the fall of the year at Winnipeg, and it carried off the prizes of the Canadian Pacific Railway Company and of the Hudson's Bay Company for the best ten bushels of wheat. At that time the Canadian Pacific Railway Company was hard at work constructing its great line of steel across the continent, and, with a view to future business, was anxious to demonstrate the agricultural possibilities of the West. About 1882, therefore, the Company began to make a series of experimental farms all along the line from Winnipeg to Calgary. Horses and plows, accompanied by laborers, were conveyed by train; and, at intervals along the line, whenever there was found a piece of open, level, promising-looking land, plows, horses and men were detrained and the virgin soil was turned up; and in the autumn the land was back-set. The Company sowed all these new farms with Red Fife purchased from Hartney in the winters of 1882 and 1883, with the result that the amount of Red Fife available for 
seed rapidly increased. The Company supplied the new seed to the settlers, with whom it was in great demand. ${ }^{94}$

In 1883 the firm of Traill, Maulson and Clark arranged for the importation into Manitoba from Minnesota of 10,000 bushels of Red Fife. The government, for the purpose of assisting in the improvement of the wheat crop, allowed this and other consignments of Red Fife intended for seed purposes to come into the country duty free; and the Canadian Pacific Railway Company, with the same object in view, held out a special inducement to importers by offering to bring in seed wheat of this variety free of charge. ${ }^{95}$

The outcome of the efforts at improvement just described was that after 1882 Red Fife soon replacel the softer wheats, such as Club, Golden Drop, and White Russian, so that in the early eighties it became the standard variety of wheat in western Canada.

Red Fife was, and still is, a first-class cereal; and it will always be interesting historically, not only for the fact that it established the reputation of the Dominion for the production of high-grade wheat with excellent milling and baking qualities, but also because it was the male parent first of Preston and subsequently of Marquis. It has been justified not merely by its own achievements but by its children.

XXIV. Marquis as the Off-spring of Red Fife and Hard Red Calcutta

The rudimentary plant or embryo present in every seed arises in the first instance from a fertilized egg; and it is

94 The above facts concerning the introduction of Red Fife into western Canada by James Hartney and the Canadian Pacific Railway Company, were kindly related to me by Mr. William Sharman of Winnipeg, who himself sowed Red Fife in Manitoba in 1883.

95 Red Fife Wheat, Manitoba Daily Free Press, Feb. 24, 1883, p. 8. 
no more possible for an unfertilized wheat egg to develop into a wheat plant, or an oak egg to develop into an oaktree, than it is for an unfertilized fowl's egg to develop into a chicken, or an unfertilized human egg into a child. That plants and animals alike spring from fertilized eggs is one of the most fundamentally important and wonderful of all biological discoveries.

Exactly how the egg which gave rise in succeeding generations to the plants from which Marquis was selected, came to be fertilized is for us a matter of no little interest, and an elucidation of it will now be attempted. Thereafter we shall discuss the influence of the parents of Marquis upon their off-spring.

The original kernel from which all the Marquis plants in the world have been derived, came into existence, as we have seen, from an artificial cross between Red Fife and Hard Red Calcutta. Pollen dust from some stamens removed with foreeps from a few flowers of the former variety, was placed on the two feathery stigmas of a flower of the latter variety. The pollen grains germinated, each grain producing a single pollen tube. The pollen tubes, which were exceedingly delicate cylindrical structures, grew down the stigmas and made their wav, by elongating at their apices, into the ovary below. This ovary was a tiny chamber containing a single ovule or potential seed attached laterally to its wall. One of the pollen tubes, guided by chemotropic stimuli, directed its course toward the ovule, entered it at its mouth or micropyle, and penetrated into its interior as far as the ovum or egg-cell. The egg-cell having been reached, the wall at the tip of the pollen tube liquefied and broke down, and from the opening so produced there were emitted two exceedingly minute dense rounded masses of gelatinous protoplasm known as male nuclei. One of these nuclei, carried by forces as yet 
not perfectly understood, advanced through the general protoplasm of the egg-cell toward the female nucleus situated in its center. The male and the female nuclei, after coming into contact, brought their affinity for one another to a climax by mingling together and forming one whole; and this nuclear fusion, this formation of a single nucleus from two others of opposite sex, marked the completion of the act of fertilization. We thus see that the train of events which received its impetus from cross-pollination, inevitably led to the production of a cross-fertilized eggcell. Without fertilization, the egg-cell would have remained just as sterile as an unfertilized fowl's egg, and in the end it would have withered and died; but, its fertilization having been accomplished, a most extraordinary future was opened to it. Further development became irresistible, with the result that, in the course of a few years, its products became in numbers like the stars on a clear night or the grains of yellow sand upon a sea beach.

The fertilized egg-cell resulting from the physical union of the protoplasm of the Hard Red Calcutta and Red Fife parents could not lie dormant, but, immediately, by celldivision accompanied by nuclear division, began to swell up and become differentiated into distinct parts. Soon it became converted into a definite embryo or rudimentary plant, with a distinct root and a little shoot, lying hidden inside the enlarging ovule and ovary which were now becoming rapidly converted into a grain of wheat. The tiny embryo, as it grew to its full size, came to be situated on one side of the basal end of the grain. Meanwhile, starch, produced from sugar sent from the leaves, and proteins manufactured from nitrogenous compounds, were accumulating in the floury part of the grain which finally came to compose about twenty-four twenty-fifths of its 
mass, the other twenty-fifth part being occupied by the embryo. The floury part of a grain in which the starch and proteins are stored is known technically as the endosperm and consists of about a quarter of a million cells. To protect the embryo and the food-laden endosperm of the kernel under discussion, two coats were developed, one from the skin of the ovule and the other from the wall of the ovarial chamber. The former, known as the testa or seed-coat, soon came to press tightly against the latter, known as the pericarp, so that in the end, a single compound horny layer came into existence on the exterior of the grain. Since this layer was red, the grain, when viewed from without, was found to possess the red color which is so much preferred to white for the hard wheats of Canada.

When the cross-bred kernel was planted in the spring, the embryonic plant within rapidly increased in size and soon pushed several roots down into the soil. It then forced its shoot upwards into the sunlight where it expanded its first green leaf. Thus the embryo grew into a seedling. All this early development was accomplished at the expense of the starch and proteins, the reserve food materials which had been stored up in the endosperm or floury part of the kernel in the preceding summer. These substances, when germination began, became converted into soluble compounds, the starch breaking up into sugar and the proteins into simpler nitrogenous bodies. The sugar and nitrogenous bodies, after becoming dissolved in water, were then gradually absorbed by the enlarging embryo, the organ of absorption or cotyledon being a shieldshaped structure attached to the axis of the embryo at the place of union of the shoot and the first root. In the course of about 115 dars, the embryo grew into a seedling and the seedling into a mature plant. The green leaves 
unfolded themselves to the sunlight one by one, and the slender stem, elongating ever more rapidly, ceased from its upward strivings neither night nor day until it had raised to the full height its precious burden - the spike of flowers. Each flower, left to itself, underwent self-pollination: the pollen dust of the three stamens fell upon the two stigmas of the same flower when the glumes opened, and, as a consequence, the so-called self-fertilization of the ovules which normally takes place in all wheat flowers, was accomplished. Finally, the flowering spike developed into a head of ripe kernels, after which the whole plant, with the exception of the kernels, gradually lost its vitality and died. Thus the life-cycle of the plant which began with the fertilized egg-cell, came to an end with the production of reproductive bodies which provided for the continuance of the species in the next year.

The plants which grew from the seeds of the original cross-bred plant were very variable. No full record was kept of this variability, but it is probable that the descendants of the original cross-bred plant became differentiated into several scores of distinct types. It was a single head of a single plant of one of these types, which was finally selected by Dr. Saunders in 1903 to provide the seeds from which Marquis originated.

Since the nucleus of the fertilized egg-cell from which sprang the plant which gave rise to Marquis, originated from the union of a male nucleus from a Red Fife plant and a female nucleus from a Hard Red Calcutta plant, and since all the millions of nuclei in the millions of cells which make up every Marquis plant have all been derived from that original nucleus, it is not surprising to find that Marquis exhibits characters of both its original parents.

Hard Red Calcutta is a very early-ripening wheat with short straw and short bearded heads. Its grains are very 
hard, red, and fairly plump, but shatter readily even when the straw is green. From Hard Red Calcutta, its female parent, Marquis has inherited its early-ripening habit. Marquis also has straw which is a few inches shorter and heads which are somewhat smaller than those of Red Fife, and here again the maternal influence of Hard Red Calcutta can be traced.

Marquis is exceedingly like its male parent, Red Fife, in general appearance. Thus it is not bearded like Hard Red Calcutta but, like Red Fife, has a few short awns at the tip of its head. Also its straw is not nearly as short as that of Hard Red Calcutta but, while shorter than that of Red Fife, is of good length. When Marquis and Red Fife are growing in adjacent fields before the ripening of the grains, even experts find it difficult to tell off-spring and parent from one another. However, careful comparison shows that Marquis is a few days earlier in its development, is not quite so tall, and has glumes enclosing the young grains which are somewhat broader and shorter.

It thus appears that Marquis stands in a more or less intermediate position between its two parents in respect to length of straw, length of head, and earliness in ripening. In one character, however, it is not intermediate, namely, in resistance to the shattering of its ripe grains. While Hard Red Calcutta shatters readily, and Red Fife shatters to some extent, Marquis resists shattering in a high degree.

\section{$\mathrm{XXV}$. The Future of Marquis}

There is no reason to believe that plant breeders have already obtained the utmost possible in their endeavors to improve the varieties of wheat now grown, for the wheatplant is a plastic thing and the limits of its rariability have not yet been ascertained. Moreover, the number of plant 
breeders who have devoted themselves to the production of new wheats has been very limited until recently, while the number of kinds of wheat in the world, the properties of which require to be investigated and with which experiments could be made, is very great. The wheat population in a field of any common kind of wheat is usually a mixed one and consists of a number of elementary varieties differing slightly from one another. ${ }^{96}$ Some of these are better than the average and some worse. By careful selection ${ }^{97}$ of the best of them, any particular kind of wheat such as Red Fife, Bluestem, or Marquis, can often be considerably improved; and it was by the employment of this method, either consciously or unconsciously, that the older workers, Le Couteur, Shirreff, and Hallett in England, Rimpau in Germany, Nilsson in Sweden, and others, obtained their many successes; and it was also by the employment of this method that Dawson of Ontario isolated his Golden Chaff,98 Haynes of North Dakota his Haynes

98 Every kind of wheat seems to have a tendency to break up spontaneously in the course of time into these elementary varieties; but what the cause of this may be, we do not know.

97 For an interesting discussion of the selection method as used by the older improvers of cereals, see Hugo de Vries, Plant Breeding, Chicago, 1907, pp. 29-90.

98 According to Professor Zavitz of the Ontario Agricultural College the wheat known as Dawson's Golden Chaff originated as follows: Robert Dawson, a farmer living near Paris, Ontario, had a field of the White Clawson winter wheat in the year 1881, which was badly lodged. In walking over the field, Mr. Dawson observed a plant standing upright in the midst of the lodged grain. He carefully saved this one plant and sowed the seed in the autumn. In a comparatively short time he had sufficient seed, not only for his own requirements, but also for sale to his neighbors. The Dawson's Golden Chaff variety of winter wheat, which possesses very stiff straw, has been grown more extensively throughout Ontario than any other variety (Wheat and Rye, Bulletin No. 261, Ontario Department of Agriculture, Toronto, 1918, p. 10). Plot tests at Guelph with fourteen varieties of winter wheat for 22 years showed that Dawson's Golden Chaff gave an annual average 
Bluestem, ${ }^{99}$ Dr. Charles Saunders of Ottawa his Early Red Fife, ${ }^{1}$ Professor W. P. Thompson of the University of Saskatchewan his remarkable Dwarf Marquis, ${ }^{2}$ and

yield of grain of exactly three bushels per acre over the next highest yielding variety (ibid., p. 7 ).

${ }_{99}$ Bluestem was being grown in 1855 in some Eastern States of the U. S. A. as a red winter wheat. It was then taken west and grown in the spring-wheat States as a spring wheat, where apparently it became harder. Haynes began to grow it in 1882 but found it mixed with some soft and bearded wheats. In 1884 he therefore planted in his garden the grains "from two good heads, having three kernels abreast, hoeing it as it grew." From the progeny of the two heads he selected only the best and earliest for the next sowing. He was then spurred on by hearing of Major Hallett's selection work in England. Eleven years of careful and continuous head selection of Bluestem resulted "in increasing the number of kernels abreast of the spikelet from three to four, with the fifth kernel beginning to make its appearance." Further, says Haynes "The length of the heads is increased about one-third, and the berry is much improved in uniformity of color and hardness. Another important feature is in the earlier maturity by five days more than formerly." L. H. Haynes, private pamphlet, $3 \frac{1}{2}$ by $5 \frac{1}{4}$ inches, 11 pages, Fargo, North Dakota, published about 1895. For a typewritten copy of this pamphlet I am indebted to Dr. H. K. Hayes, in charge of Plant Breeding at the Minnesota Experiment Station, St. Paul.

1 Saunders' strain of Early Red Fife was obtained from a single early-ripening plant occurring in a plot of Red Fife. It is just like Red Fife in appearance but ripens a few days earlier (C. E. Saunders, Methods of Selection, Experimental Farms Reports for 1909, pp. 202-203).

2 Dwarf Marquis, which with Professor Thompson's permission is here mentioned in cereal literature for the first time, has heads of the same length as those of Marquis but straw which is only one-quarter of the usual length or even less. It arose from a single dwarf plant which came to perfection in a plot of pure-line Marquis at the University of Saskatchewan, and it has bred true for several years without any signs of breaking up. It never gives rise to tall plants; the progeny of each year are all dwarfs. Dwarf Marquis, owing to its excessively short straw is, of course, of no commercial importance but it is of high interest as bearing on the genetics of wheat. The writer in 1918 saw Dwarf Marquis at Saskatoon growing in one of Professor Thompson's plots and it presented a very striking contrast with Marquis. An interesting parallel is afforded 
Mr. Seager Wheeler of Rosthern his Kitchener and his Red Bobs. ${ }^{3} \quad$ But of late years another method of improving cereals, that of cross-breeding, has been perfected and already its application has led to the introduction of Marquis and Prelude into the great spring-wheat region of North America and of the rust-resistant Little Joss into England. ${ }^{4}$ These cross-bred wheats combine the most desirable characteristics of both their parents. Every year now sees the advent of new varieties of wheat obtained by one or the other of the two methods just described. Taking all these facts into consideration it seems not only quite possible, but even likely, that at some time in the future Marquis will be replaced by some other variety of wheat, or perhaps by a succession of varieties, which will be superior to it in one or more characteristics such as earliness, yield, resistance to disease, ${ }^{5}$ and so forth. Indeed, it is to

by the dwarf Evening Primrose, Oenothera nanella, which arose in one of de Tries's plots at Amsterdam and which is only one-third of the height of its tall parent Oenothera Lamarckiana.

3 Kitchener originated in 1911 from a single plant of Marquis which to Mr. Wheeler's eye stood out from its fellows as a distinct type. Red Bobs was selected from Bobs. In all probability, Dawson's Golden Chaff, Early Red Fife, Dwarf Marquis, and Kitchener all came into existence in the first instance as mutations or sports from a single parent. The writer is convinced, however, that Red Bobs originated from the progeny of a natural cross, accidentally occurring in Mr. Wheeler's plots, between Bobs and either Preston or Early Red Fife. The evidence upon which this view is based, is given in the Chapter on Red Bobs.

4 The pioneer producer of wheat hylorids in North America appears to have been C. G. Pringle of Charlotte, Vermont. He began his work in 1877 and several varieties have received his name, some of which have become standards. (P. T. Dondlinger, The Book of Wheat, New York, 1912, p. 44.) Dr. William Saunders of Ottawa began to cross wheats in 1888 .

5 The wheat crops of the world suffer enormous diminution in yield every year through such diseases as Rust, Smut, Wheat Scab, and Root-rots. The attempt to produce disease-resisting cereals has only just begun. 
be hoped that such a change as that indicated will actually take place; for wheat is merely a convenient means of providing the most civilized countries of the earth with food, and every real improvement in the varieties grown brings with it economy of labor in a task which by its very nature man can never shirk - the task of procuring his daily bread.

In the early eighties of last century and until the introduction of Marquis in 1909, a period of twenty-five years, Red Fife (Scotch Fife) was regarded by many as the incomparable spring wheat destined to maintain its sway in a large part of North America forever. In 1883, in an issue of the Manitoba Daity Free Press it was correctly described as then being "unsurpassed." But just as Red Fife replaced Golden Drop, White Russian, Red Chaff, Ladoga, Club, and other varieties in Manitoba, so, in its turn, it has been replaced over vast areas by Marquis. Already, however, in certain of the more northerly parts of the Canadian wheat-belt, Prelude has replaced Marquis; and the new Ruby, should it prove successful in its present trials in the field, may possibly replace Prelude. Red Bobs is also a very fine wheat and has entered the competition for premier honors in the great spring-wheat region. What its future may be time alone will show. At present there are only a few acres of this wheat in existence, but where it has been grown it has shown great promise. The hope built upon it may possibly be justified within a few years; but it is well not to forget that there is a considerable difference between a promising new variety grown in a few fields and that same variety covering enormous stretches of the prairie and vielding, as Marquis actually does, from $200,000,000$ to $300,000,000$ bushels of wheat a year. It seems certain, for mechanical reasons alone, that Marquis cannot be dislodged from its 
position as the dominant spring wheat in western Canada within five years; and it is probable that it will still hold the lead over large tracts of country ten or twenty years hence.

Marquis, even if it retains its great place for only ten or even five years more, will have been of enormous practical advantage to the world during the most critical stage of its history, for some hundreds of millions of bushels of it have been conveyed to Europe during the past four years of the Great War to feed the soldiers of the Allies in the field and to sustain the civilian populations of the British Isles, France, Italy, Belgium and Greece at home. In a very real sense Marquis has done much to strengthen the sinews of war of those fighting for the great cause of liberty, and therefore has been no small factor in making; victory possible. It is certain that had Marquis not replaced Red Fife in the great spring-wheat area of North America, the world's supply of wheat during the late food crisis would have been many millions of bushels less than it actually was.

\section{Saunders and Burbank}

Were there in existence a book recording the services of all those who have deserved the gratitude of their fellowmen for the improvements they have brought about in cultivated plants, its pages would be many and its roll of honor a very lengthy one. Some day, perhaps, the triumphs of the plant breeder will be set down in the history of a nation as of no less importance than the valorous deeds of brave men performed amid blood and mud and the thunder of great guns upon the field of battle; but this can scarcely be hoped for until the world has entered upon its future development in the spirit of a united family.

Only very few of the names of the leaders in the science 
of plant breeding are widely known. Of Gregor Mendel, the Austro-Silesian monk who, by experiments upon the edible Pea, discovered the now famous Mendelian Laws of Inheritance, and of the Dutchman, Hugo de Vries, who, by his Mutation Theory of Evolution, has also contributed much to plant breeding on its theoretical side, many have heard; but, so far as the practice of plant breeding is concerned, only one name is generally known to the public, that of Luther Burbank. He, indeed, may be said to have acquired universal fame. By means of books, of magazines, and of newspapers, the story of his achievements has been blown, as it were, upon the wind, so that at the present time there is scarcely an intelligent man whose ear it has not reached. Who has not heard of Burbank's potato, of Burbank's plums, of Burbank's berries, of Burbank's spineless cacti, and of Burbank's Shasta Daisy ; and who does not know that these are but a few only of the many novelties that have issued from the celebrated garden of Santa Rosa? Who has not been impressed by the skillful way in which Burbank has chosen the best variations from plots of thousands or tens of thousands of plants in which to the ordinary eye all the individuals look alike? And, finally, who has not felt astonishment at the often surprising products which have issued from his hybridizing experiments? Many are the delights which Burbank has contributed to the garden and the orchard. By his hard work, his persistency, his skill, his excellent judgment, and his many successes he has truly deserved the reputation he has aequired, and he will leare behind him a heritage of plants which will keep his memory green for many generations. On the other hand, the names of the other masters in the realm of plant breeding, whose new kinds of wheat, barley, oats, Indian corn, potatoes, flax, grapes, melons, fruit-trees, etc., have had, and are having, 
an immense influence upon human history, remain unknown to the general public; and among them is that of Dr. Charles E. Saunders whose Marquis wheat is the theme of this essay. Of farmers and others who handle grain in western Canada the writer has often asked the question: who discovered and introduced Marquis wheat? and not so many as one in ten have been able to give a correct answer. The name of Charles E. Saunders has received no advertisement: neither book nor magazine article has ever been written about his labors and his achievements; but it may safely be said that the economic importance of Marquis which he discovered and gave to the world, by far outweighs at the present moment that of all Burbank's novelties put together. The writer does not wish in any way to minimize the great interest and value of Burbank's work in stating that Burbank's efforts at improvements have not been chiefly concerned with the leading food-plant. One's delight in beautiful flowers is entirely æsthetic, and one does not live on spineless cacti, upon plums, cherries, raspberries, or walnuts, and comparatively few eat the Burbank potato; but bread is truly the staff of life for the most progressive part of the population of the globe. The eating of wheaten bread, like the using of soap, is a mark of civilization; and a great improvement in the king of cereals is therefore of the utmost importance to everybody.

This year, 1918, upon the prairies of western Canada and in the Great Plains region of the United States of America, there have been produced more than 300,000,000 bushels of Marquis, a mass of wheat sufficient to provide for a whole year the normal bread and other wheat requirements of a population of $50,000,000$ people. The average selling price for the 1918 wheat crop has been 
fixed at about two dollars a bushel. ${ }^{6}$ Taking two dollars a bushel as the average price, it is obvious that the crop value of Marquis wheat for the year 1918 is upwards of $\$ 600,000,000$. This sum by far exceeds in amount the whole fruit-growing industry in California which for the year 1917 has been estimated by Mr. E. E. Kaufman at $\$ 107,000,000 .^{7}$ About a dozen years ago the California fruit-growing industry was smaller than it is to-day and it was then considered to be worth $\$ 60,000,000$ per annum. ${ }^{8}$ Of this amount de Vries, in 1907 , estimated that Burbank's contribution was scarcely one per cent., ${ }^{9}$ but there can be no doubt that this contribution has grown considerably since then as more of the fruit-trees have

6 From data supplied by Mr. Irvine, the Assistant Secretary of the Winnipeg Grain Exchange.

7 For data concerning the value of the California fruit-crop I am indebted to Mr. E. E. Kaufman, Field Agent of the Bureau of Crop Estimates of the United States Department of Agriculture, and to Mr. Howard C. Rowley, publisher of the California Fruit News. Mr. Kaufman's estimates of the value of the fruit crop to the growers for 1917 is made up as follows:

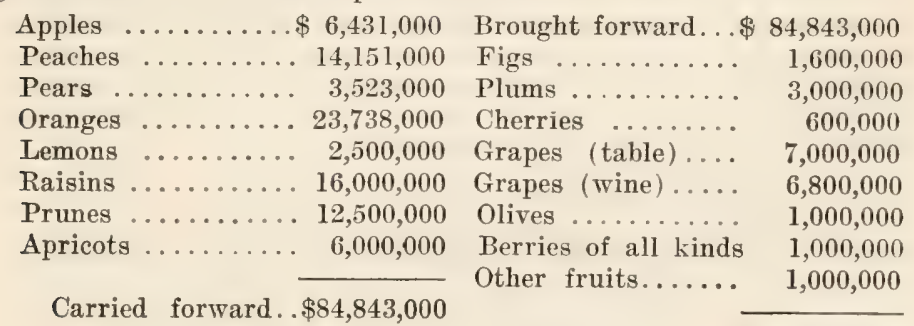

Total

$\$ 106,843,000$

Using a somewhat different basis of calculation and including the cost for boxing and packing of oranges and lemons, etc., and adding $\$ 10,000,000$ for nuts, Mr. Rowley has calculated that the value of the California fruit crop for 1917 was not less than $\$ 150$, 000,000 and was probably between this sum and $\$ 175,000,000$.

8 Hugo de Vries, Plant Breeding, Comments on the Experiments of Nilsson and Burbank, Chicago, 1907, p. 178.

9 Ibid. 
come into bearing. From inquiries made by the author, it seems probable that Burbank's contribution to the total fruit erop of California in 1917 did not exceed three per cent. or, in round figures, $\$ 3,000,000 .{ }^{10}$ Burbank's potato has a higher crop value than his fruits. After its general introduction it was stated by the United States Department of Agriculture that it was adding to the agricultural productivity of the country an annual sum of $\$ 17,000,000 .^{11}$ If to this $\$ 17,000,000$ for potatoes we

10 Of the total California fruit crop, peaches, citrus fruits, prunes, apricots, and European grapes form a very important part, and Burbank, as I am informed by Mr. J. C. Corbett, Horticulturalist in charge of cultural and pomological investigations for the United States Department of Agriculture, has contributed very little to the variety list of this group of fruits. Burbank's chief contribucion to the fruits of California is to be found in his plums and cherries which, e.g., the Wickson plum and the Burbank plum, are shipped away from the State in great quantities. However, the total value to the growers in 1917 of California plums was only $\$ 3,000,000$ and of cherries only $\$ 600,000$, and there are many other plums grown in the State beside those originated by Burbank. It is therefore very doubtful whether Burbank's plums and cherries represent half of the $\$ 3,600,000$ here given. In his circular called 1918 Offerings of Twentieth Century Fruits, etc., Burbank states that 1,092,256 crates of his plums and cherries had been shipped away out of the State of California in the season of 1918 before November 15, besides other shipments made by one large shipping firm which could not make a varietal report. Supposing we take the total of crates at $1,200,000$ and reckon the fruit that was put in them as being worth to the grower (exclusive of boxing and packing) as much as one dollar a crate, then the value to the grower of all the fruit in the crates would be $\$ 1,200,000$. In arriving at the figure of $\$ 3,000,000$ for Burbank's contribution to the fruits of California given in the text, I have added to this $\$ 1,200,000$ the large sum of $\$ 1,800,000$, so as to allow for other fruits, contingeneies possibly overlooked, and so as to err on the generous side of the account.

11 Hugo de Vries, loc cit., p. 164.

Mr. William Stuart, Horticulturalist engaged in cultural and pomological investigations for the United States Department of Agriculture and a well-known authority on the potato, has kindly informed me that the Burlank potato at present: is confined very largely to the northwestern portion of the United States; that it is 
add $\$ 3,000,000$ for fruit, we obtain $\$ 20,000,000$ which we may consider to be a rough estimate of Burbank's total contribution to the annual crop values of the United States. This sum is only an approximation to the truth; it may be too small and it may be too large; but even if we were to multiply it by ten, it would still fall far short of the $\$ 600,000,000$ which is the estimated crop value of Marquis wheat for the year 1918.

\section{Burbank's Quality Wheat as a Possible Com- petitor of Marquis}

Having heard that Luther Burbank was introducing some new varieties of wheat, I wrote to the great plant breeder for particulars concerning them. Mr. Burbank, in reply, kindly informed me that he had added my name to the sixty-five thousand others who receive his catalogues and circulars, and called attention to what he described as "my best wheat" to which he has given the name Quality. He also communicated to me the interesting information that Quality " is a derivative of Prize Marquis" and that it was " secured by many years' selections for certain qualities in which our California wheats are lacking." It is worthy of note that Marquis which was originally selected by Dr. Saunders at Ottawa should have been grown to a slight extent in Wisconsin, Nebraska, and Colorado, the Russet type prevailing in Nebraska and Colorado; that it is chiefly grown in the San Joaquin and Sacramento valleys of California and in some portions of Oregon and Washington; and that probably it does not exceed 5 per cent. of the total potato crop of the United States. Mr. Burbank himself in his 1918 New Creations and Special Nevo Selections states that more than $500,000,000$ bushels of the Burbank potato have been raised during the past forty years. This is a magnificent total, but assuming that the average price has been as much as 80 cents per bushel, the crop value of the $500,000,000$ bushels of Burbank potatoes to the growers has been $\$ 100,000,000$, or two-thirds of $\$ 600,000,000$, the estimated erop value for Marquis wheat for the single year 1918 . 
so long studied and made the basis of further selections by Mr. Burbank in so distant a State as California.

In a circular called Burbank's 1918 New Standard Grains, issued from his Experimental Farms at Santa Rosa, Burbank, under the head of: A New Productive White Wheat - "Quality," makes the following statements: "This season I offer a superior, early, hard white wheat suited to all climates wherever wheat can be grown; as a Summer wheat in cold far Northern climates and as a Winter crop in the United States and most wheatgrowing countries. It is specially adapted also to short seasons, arid soils, and dry climates. A superior milling wheat which makes the best light sweet nutritious bread and pastry. ... This early hardy Quality wheat which I offer this season will not yield as much as some of the coarse macaroni wheats in some warm, dry sections, but for general culture, with its unusual hardiness and extreme earliness, uniformity, superior milling and baking qualities, it stands alone. It most resembles in all these respects the hard Northern Prize Marquis but has a vitreous white berry of quite different appearance and quality and of about the same specific gravity as of granite." Quality is offered to the public at $\$ 5$ per pound or $\$ 45$ for 10 pounds, i. e., at the rate of $\$ 2 \% 0$ per bushel, so that it is doubtless the most expensive wheat in the world. Only as its price goes down can farmers hope to purchase a sufficient quantity of seed to cultivate it on a large scale and thus make it an article of commerce so far as the miller and baker are concerned. ${ }^{12}$

12 In his Burbank's 1918 New Standard Grains, Mr. Burbank advertises for sale two other varieties of wheat in addition to Quality: Quantity offered in 1918 for the first time and Super first offered in 1917. Quantity is on sale at the same prices as Quality, i.e., $\$ 2.75$ for 0.5 pound, $\$ 5$ for 1 pound, $\$ 23$ for 5 pounds, $\$ 45$ for 10 pounds, $\$ 1$ for 10 sample heads, and 60 cents for 5 sample heads. 
Mr. Burbank, in support of the claims which he makes for Quality, publishes the results of a chemical analysis and of a baking test of the flour, and for the rest leares us to rely upon his reputation for producing new and useful plants. But Mrr. Burbank is only just beginning his work as an introducer of new wheats and the writer cannot help feeling that in penning his advertisement of Quality he allowed his enthusiasm for his new cereal to be mixed a little too freely with his ink. Every one knows that Marquis is a hard wheat, but when Mr. Burbank tells us that Quality which has been selected from it, has kernels "with about the same specific gravity as granite," surely he is addressing us in the language of hyperbole. Of two equal-sized sacks, one filled with Quality wheat and the other with erushed granite, which would the reader prefer to carry, were he obliged to make a choice?

Mr. Burbank tells us that Quality is "suited for all climates wherever wheat can be grown, as a Summer wheat in cold far Northern climates and as a Winter crop in the United States and most wheat growing countries"; and all this we are supposed to accept on Mr. Burbank's unsupported ipse dixit. $\mathrm{He}$ is silent in regard to the Quantity is thus described: "It is a tremendous yielder, having long, drooping, well-filled heads laden with extra large, fat, lightcolored berries. My small field of Quantity has been the wonder and surprise of the season. It has a stiff four-foot straw which stands up bravely with its long, heavy, well-filled heads averaging on ordinary soils five to six and sometimes seven inches in length. No good wheat yields more than Quantity. It is remarkably true to type and yields nearly twice as much as the ordinary wheats. Quantity is medium early and will prove its tremendous yielding abilities in any except the most Northern latitude." This brief description contains no statement as to whether Quantity is hard or soft, a spring variety or a fall one, and it contains no reference to milling and baking qualities, shelling, disease resistance, and so forth. Super wheat was offered this year at $\$ 3$ for 1 pound, $\$ 18$ for 10 pounds, ete.; but no more seed is just now available as the stock which was on hand has all been sold. 
exact data of his field tests and affords us no evidence that Quality has ever been compared with Red Fife, Marquis, Bobs, Prelude, Preston, and Bluestem, etc., outside of California in the great spring-wheat region of the United States and Canarla or with the various winter wheats east of the Rocky Mountains where the climate is mild enough to pemit of their cultivation. Such comparisons may have actually been made under varied climatic conditions all over Canada and the United States; but, if so, the writer has not heard of them. Is it not possible that Mr. Burbank has confined his experiments to the one State of California and that in claiming that Quality is suited for all climates, is in reality simply expressing a pious hope which, while it may some day be fulfilled, has not as ret been justified by a series of critical tests?

Rurbank's Quality is a white wheat. However, the demand in the British market, so far as Canada is concerned, is for wheat having a good red color; and there is therefore a sound commercial reason for encouraging the production of such red wheats as Marquis and Red Fife in the west of Canada rather than white wheats. It is therefore certain that, even if Quality were suited to the climate of the Prairie Provinces, there would be considerable opposition to its introduction into this area on the part of grain merchants, millers, and farmers alike.

That Mr. Burbank, with his forty years of experience in successful plant breeding should, sooner or later, introduce some very desirable new varieties of wheat is only what one is justified in expecting of him; and doubtless Quality is an improvement on the wheat grown in various localities, particularly in California. Howerer, there does not at present appear to be any good reason for believing that Quality will ever replace Marquis either in 


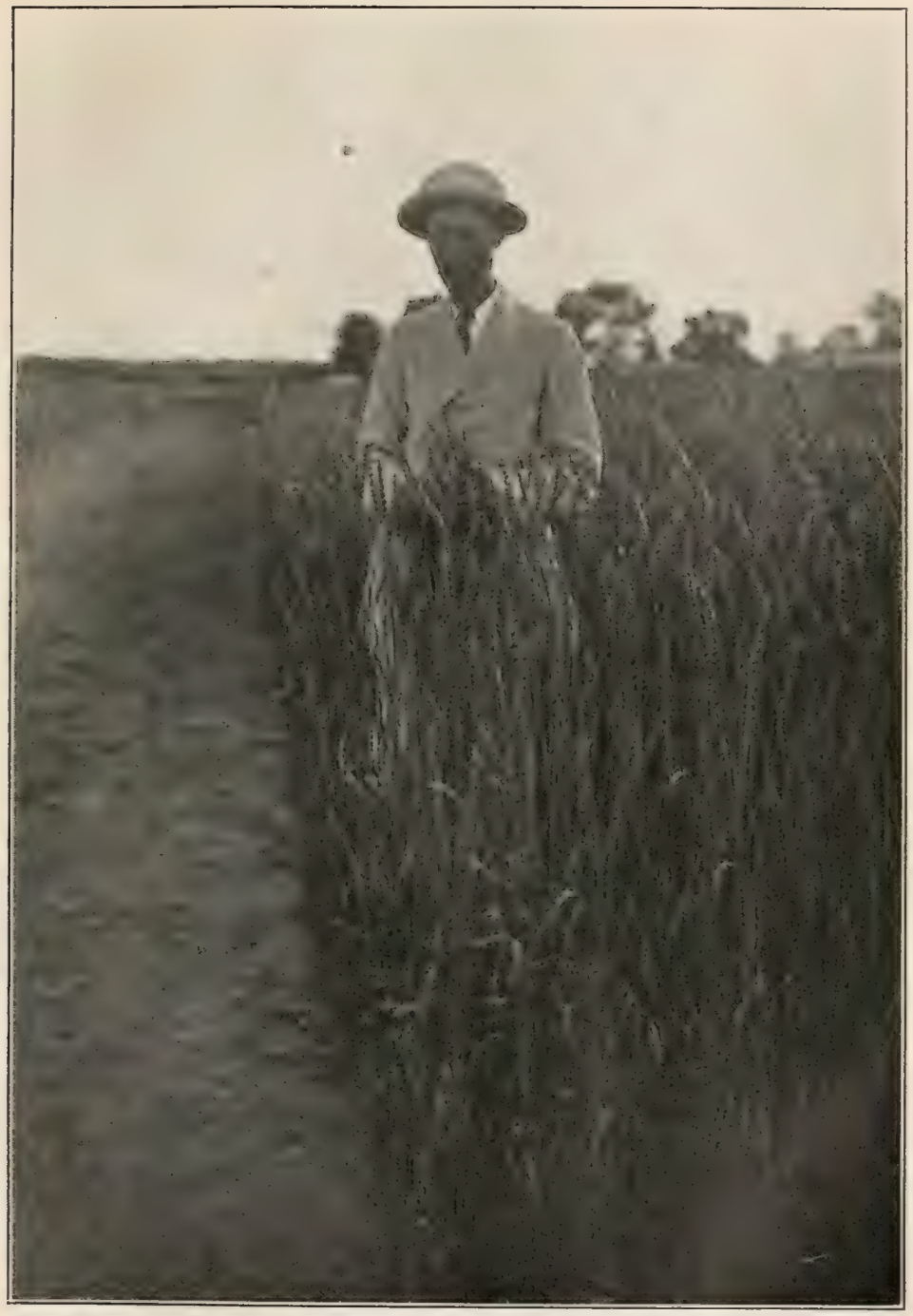

Fig. 36. Dr. Charles Saunders in a field of Marquis wheat. Ottawa. August, 1918. 

the Prairie Provinces of Canada or in the north-central spring-wheat region of the United States.

\section{Biographical Sketch of the Discoverer of Marquis}

Dr. Charles E. Saunders, the discoverer of Marquis wheat, was born at London, Ontario, in the year 1867; and he is therefore a Canadian by birth. He received his early education at the London Collegiate Institute, and from there proceeded to the University of Toronto, where he graduated as a Bachelor of Arts, with Honors in Science, in 1888. He then studied for three further years at the Johns Hopkins University at Baltimore, where he earned his doctorate by taking the degree of $\mathrm{Ph} . \mathrm{D}$. in 1891. This record shows that Dr. Saunders received a first-class scientific education. In 1892, Dr. Saunders married Miss Mary Blackwell of Deer Park, Ontario. From 1892 to 1893 he was a Professor at the Central Lniversity in Kentucky. In addition to his attraction toward science, Dr. Saunders had, and still has, a great lore of music; and he became a masterly player on the flute and took a keen pleasure in song. There was danger that music and not science would claim him for his life's work. For some years he devoted his entire attention to voice culture and to this end studied both in New York and in London, England. He became musical instructor at Havergal College, Toronto, and then at the St. Nargaret's Ladies College in the same city. Subsequently he led the choir at the Dominion Methodist Church at Ottawa; and it was during this period that he assisted his father in the work of improving wheats. This return to applied science resulted in Dr. Saunders being appointed Dominion Cerealist in 1903. 
There may be some who have been inclined to suppose that the discovery of Marquis was nothing more than a lucky accident; but such a supposition is entirely erroneous. The details of the career of Dr. Saunders, as outlined above, show us that the discoverer of Marquis was a man who had had a thorough preparation for his work by studying for several years at two of the best universities on this continent. His training had given him the necessary insight into the problem of wheat-breeding, mastery of method, resource for difficulties, and unfailing patience. In the winter of 1903-04 when he was making the chewing tests which led to the discovery of Marquis, Dr. Saunders was no mere boy, for he was 36 years old. His salary at that time was indeed small - only $\$ 100$ per month but he was rich in the possession of faculties which had been taught to do his bidding and endowed with the courage and determination of a man in the prime of life. How well he employed those faculties is now a matter of history. In his own domain of breeding cereals he has won the place of a king.

\section{Governing Bodies and Scientific Research}

When the Universities of Toronto and Johns Hopkins were giving instruction to Dr. Saunders, they little thought that, in the course of a few years, the work of one of their quietest and least obtrusive students would lead to the production of increased wealth in North Ameriea more than sufficient to defray the annual cost of their growth and maintenance; but, by training men of the stamp of Dr. Saunders, those institutions have fully justified their existence; and, in return, they need not hesitate to claim the heartiest support of the public. In the story of the discovery of Marquis wheat, governing bodies everywhere may find a striking illustration of the wisdom of giving 


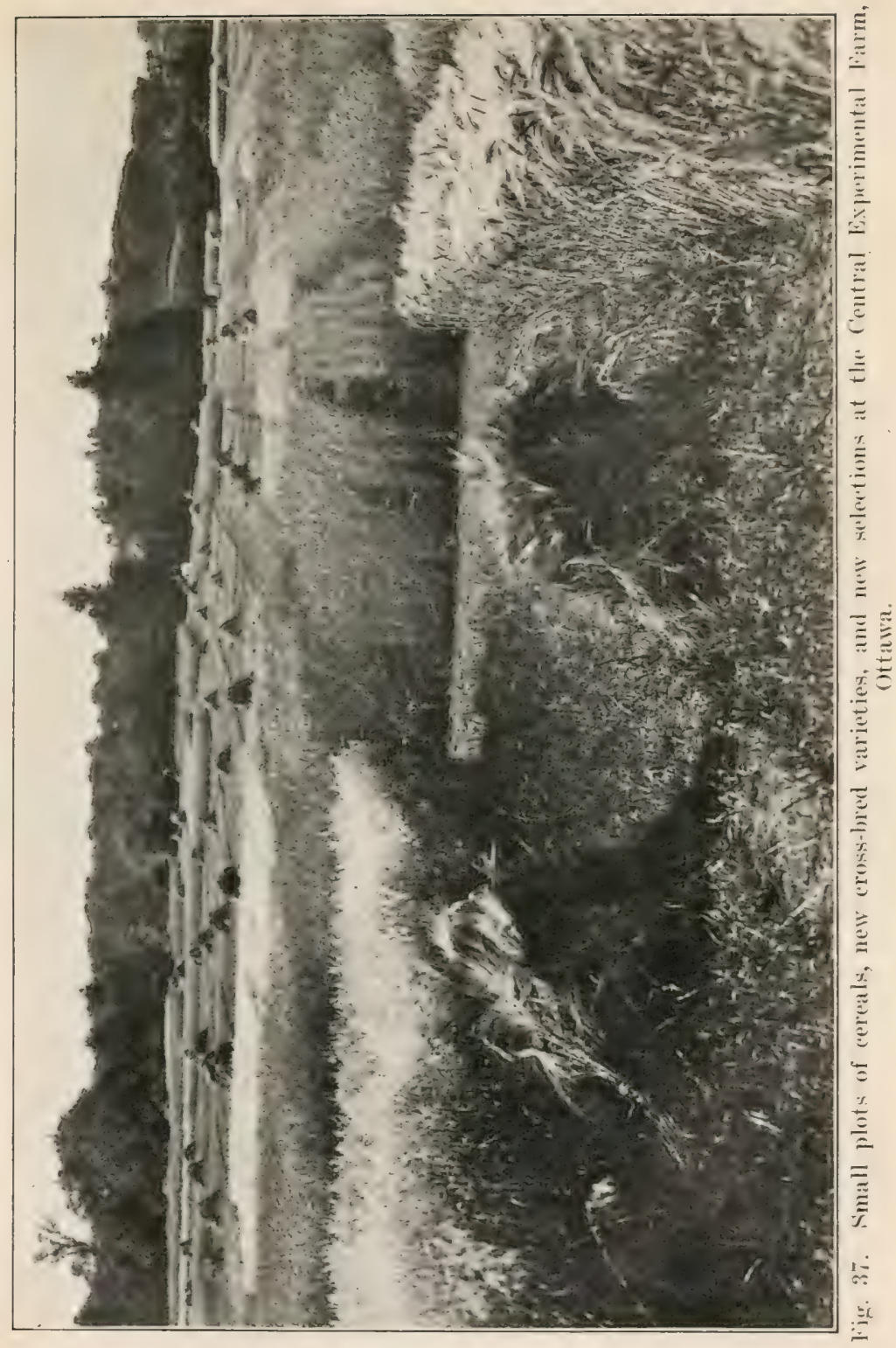




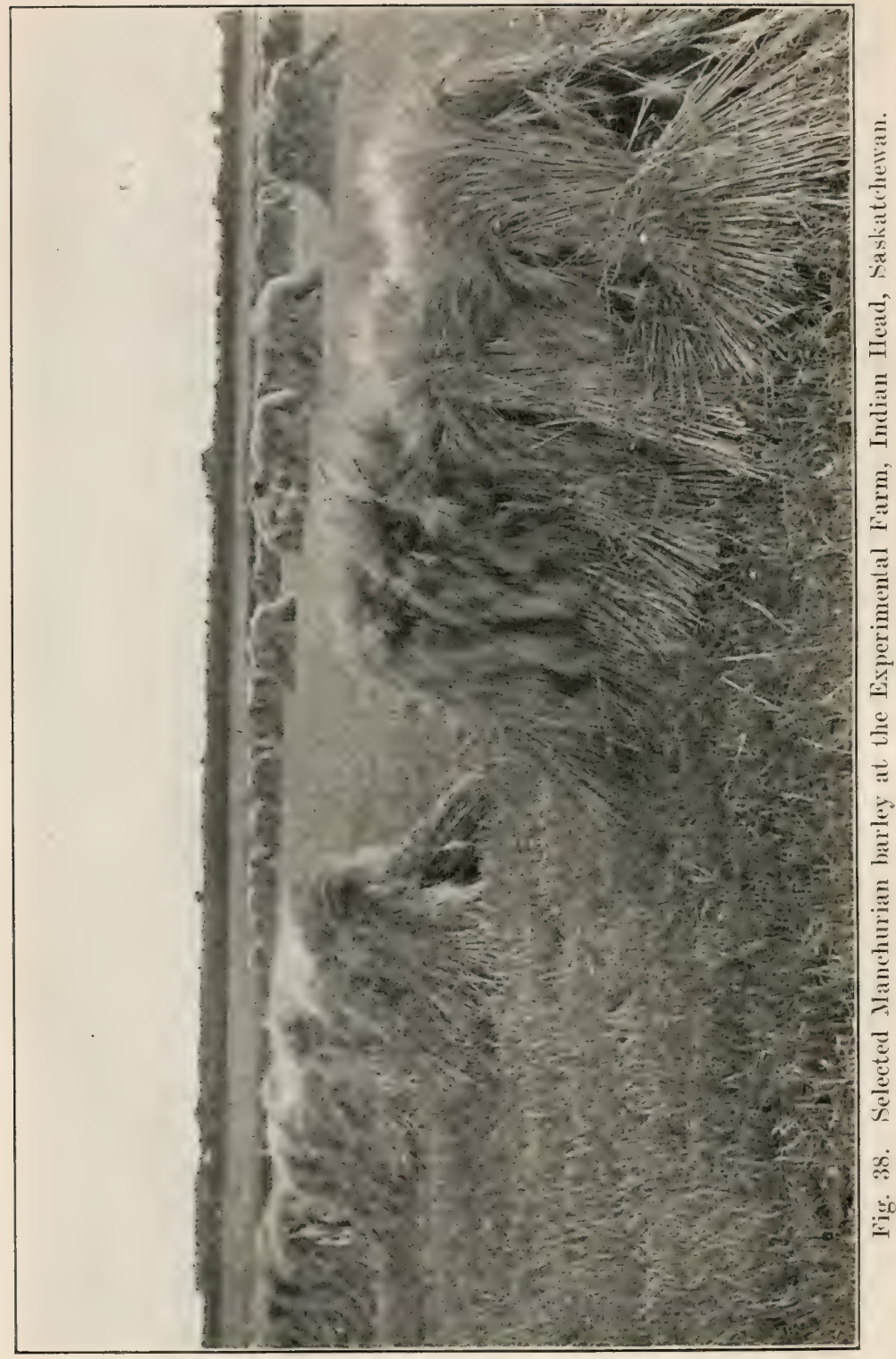


adequate financial and moral support to investigations directed toward the welfare of the State. The starvation of scientific research is truly the worst economy of which a statesman can be guilty.

\section{Other Work of Dr. Saunders}

In addition to his work upon wheat, Dr. Saunders, as Dominion Cerealist, has been engaged in making selections of, and in breeding, new types of other cereals and of peas. From Mensury barley (of supposed Manchurian origin) Dr. Saunders made a selection ealled Manchurian which is a fine six-rowed bearded variety with an excellent yield. It has been grown successfully on a large scale in various parts of Canada. Another selection known as $O . A$. C. No. 21 was made by Professor C. A. Zavitz at the Ontario Agricultural College from a barley which he obtained under the name of Mandscheuri. These two varieties have added much to the productivity of barley in this country. ${ }^{13}$

13 Mandscheuri barley was imported from Russia by the Ontario Agricultural College in the spring of 1889 . It was found to be more productive than any of the other six-rowed barleys tested: it gave an average yield of 9.3 bushels per acre per annum over the Common Six-rowed barley as an average for fifteen years; and it was therefore introduced into general cultivation in Ontario. In 1905, Professor Zavitz pointed out that barley production in Ontario had risen from 24.85 bushels for the ten-year period 1885-94 inclusive to 29.3 bushels per acre for the ten-year period 1895-1904 inclusive; and he attributed the general rise in productivity of $4 \frac{1}{2}$ bushels per acre to the substitution of Mandscheuri barley for lesser yielding varieties. After calculating the increased value which was accruing to the Ontario barley crop through the raising of Mandscheuri, he asked of the public and the legislators, without whose intelligent support the work of agricultural colleges cannot properly be carried on, the following very pertinent question: "From these results, does it not appear as though the introduction of Mandscheuri barley by the Ontario Agricultural College has been worth to the Province of Ontario within the past ten years an annual money value equal to 
Dr. Saunders is now studying a large number of hulless and hooded (beardless) types of barley, most of which have been cross-bred. He is endeavoring to produce a first-class barley with the hull attached but free from awns. Hulless barley is already being raised to a certain extent in Alberta for the feeding of pigs, but Dr. Saunders expects that some of his new sorts will prove superior to the varieties now in cultivation. If hulless barley were raised in sufficient quantity, it would obviously be of considerable value for human food, for it would not require so lengthy a preparation as the hulled varieties at present employed for this purpose. Another interesting barley which Dr. Saunders is now introducing is called Albert. It is of cross-bred origin and extremely early in ripening. It will not be of general utility where a very high yield is a first consideration but may become valuable where the growing season is a short one.

Dr. Saunders has originated a new hulless oat which he has called the Liberty Oat. It threshes out free from the hard and tough glumes which enclose the grains of every common kind of oat, and will therefore probably be much appreciated for feeding chickens and young pigs. It also makes oatmeal of very fine quality, and Dr. Saunders believes that it has a richer flavor than any of the commercial oatmeal products which he has tasted.

The Arthur pea and the Mackay pea were produced many years ago under the direction of Dr. Saunders' father. The Arthur is now making good headway among growers. It is one of the earliest field peas and is, therefore, advantageous for many districts in Canada where earliness is a desideratum. The Mackay was named by Dr. Saunders' father after Mr. Angus Mackay who for more than fifteen times the entire cost of the College?" Vide C. A. Zavitz, The Results of Field Experiments with Farm Crops, Ontario Agricultural College, Bulletin No. 140, 1905, p. 7. 


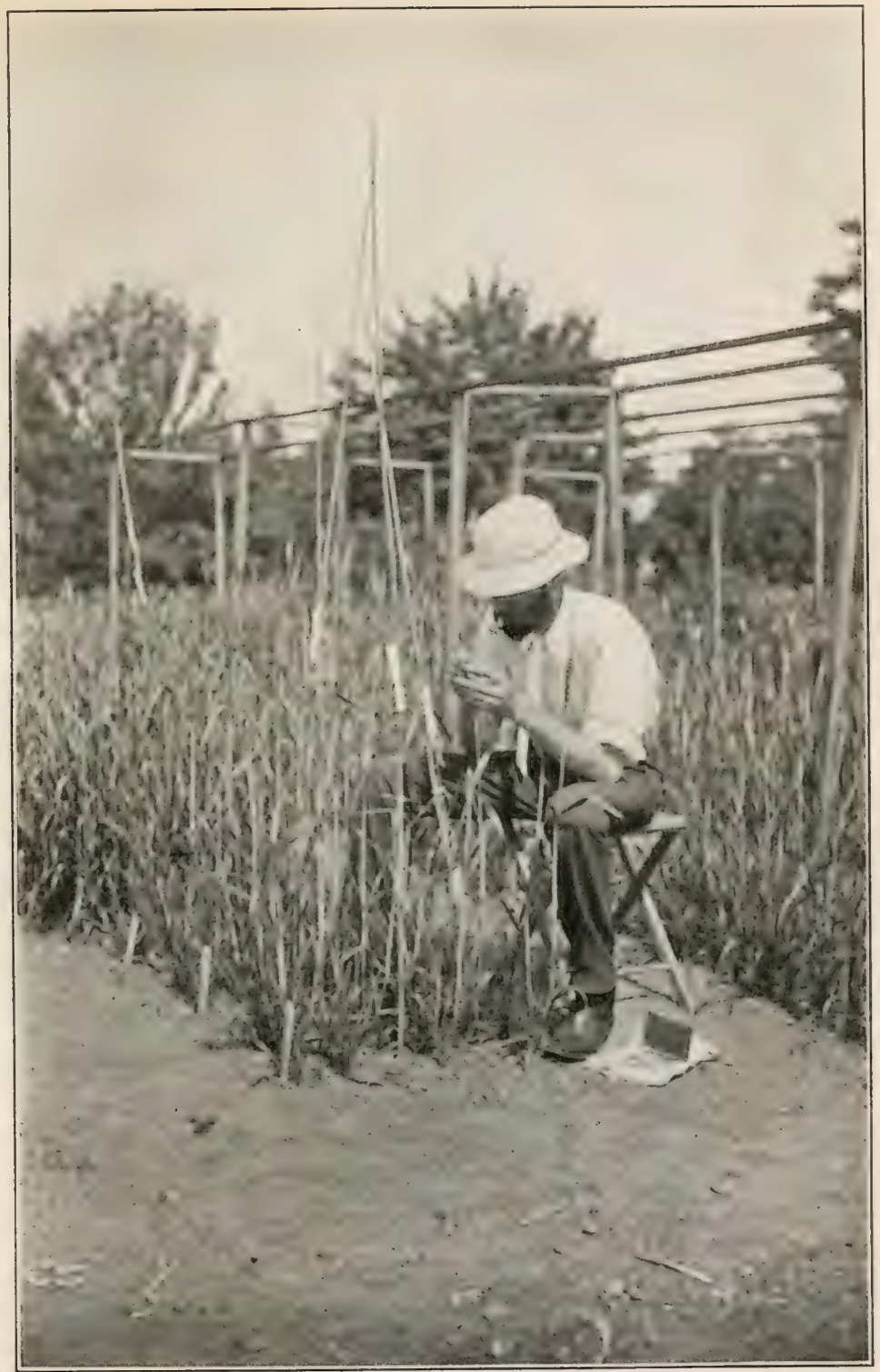

Fig. 39. Dr. Charles Saunders crossing wheats at the Central Experimental Farm, Ottawa. After pollination the heads are wound with cheese-cloth and then tied loosely to sticks. 


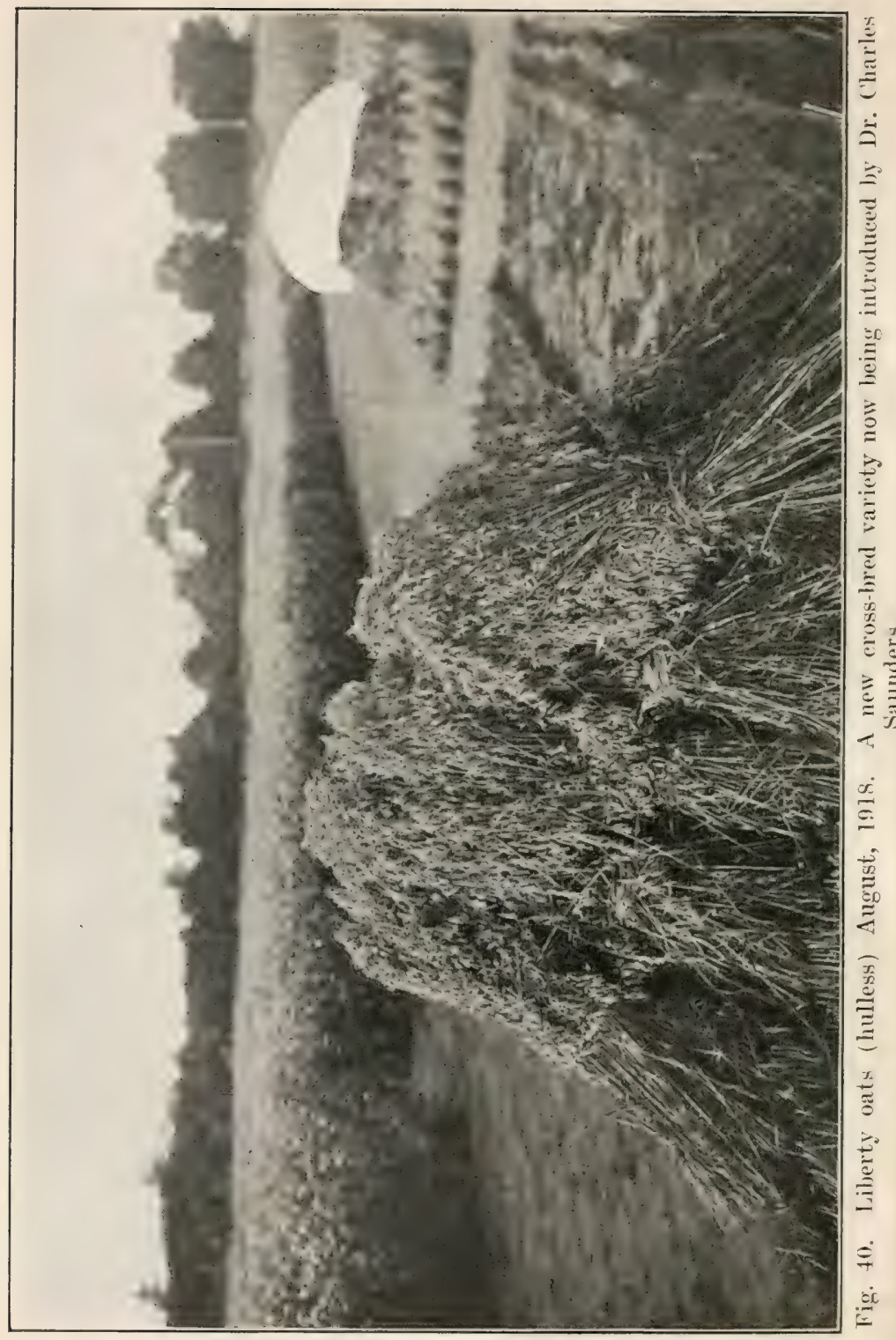


many years was the Superintendent of the Dominion Experimental Farm at Indian Head. It is somewhat later than the Arthur pea but is still more productive. It has been grown at the experimental farms for several years and has been recently re-selected with a view to its being sent out to the public. In addition to studying the Arthur and the Mackay peas originated by his father, Dr. Saunders is selecting a considerable number of pea types of his own breeding. It is to be expected that at least some of them will eventually prove of sufficient value for introduction to growers; but the work of selecting and testing them for their yield and other qualities has not yet been brought to a conclusion.

From what has been already said in the foregoing pages in respect to cereals and peas only, it is evident that there is still very much to be done by the Department of Agriculture and by provincial institutions in adapting cultivated plants to the diverse soils and climates of the broad Dominion. Judging by the experience of the past, there is every reason to believe that Canada will be well repaid for any future expenditures of time, money, energy, and brain power, which she may make in earrying out this work.

Dr. Saunders has influenced agriculture not only directly through the new cereals which he has introduced but also indirectly, through his Reports and Bulletins published by the Department of Agriculture, and through his scientific papers. Other cerealists in Canada, the United States, England, Australia, etc., have read these contributions to science, and have been stimulated in their work accordingly. Some of Dr. Saunders' research methods have now been adopted by other investigators.

The following is a list of publications on cereals made by Dr. Charles E. Saunders: 
Reports on Cereals in the Annual Reports of the Dominion Experimental Farms, 1903 to 1917.

Bulletins issued by the Dominion Experimental Farms: ${ }^{14}$

No. 45. Emmer and Spelt.

No. 50. The Grades of Wheat. Crop of 1904.

No. 57. Quality in Wheat.

No. 60. The Grades of Wheat. Crop of $190 \%$.

Circular, issued by the Dominion Experimental Farms:

Preston and Other Early-ripening Wheats. (March, 1908.)

Papers read before the American Breeders' Association, and

published at Washington, D. C., in the Proceedings:

A Natural Hybrid in Wheat in Vol. I, 1905.

The Cross-fertilizing of Cereals in Vol. II, 1908.

Papers read before the Canadian Seed Growers' Association, and published at Ottawa by the Dominion Government:

Quality in Wheat (Third Annual Meeting), 1906.

The Production of Improved Varieties of Cereals (Fifth Annual Meeting), 1909.

Distribution of Seed at Experimental Farms (Eighth Annual Meeting), 1912.

Difficulties Encountered in the Propagation of Pure Seed (Tenth Annual Meeting), 1914.

The Inheritance of Strength in Wheat, Journal of Agricultural Science, 1909, page 218.

Wheat Breeding in Canada, read before the British Association for the Advancement of Science at Winnipeg, Manitoba, 1909.

The Inheritance of Awns in Wheat, published in the Report of the Third International Conference on Genetics, Londou, 1906. (Published by the Royal Horticultural Society.)

Production de Variétiés de Blé de haute valeur boulangère, published in the Report of the Fourth International Conference on Genetics, Paris, 1911.

Cereal Breeding on the Dominion Experimental Farms during the past Decade, Transactions of the Royal Society of Canada for 1913 .

14 The second sections of Nos. 50, 57, and 60 were written by Dr. Frank T. Shutt, the Dominion chemist. 
XXXI. The Crop Values of Marquis in Canada and the United States

In Canada the crop value of Marquis for the years 1917 and 1918 ean be calculated roughly without much difficulty. In both these years at least 80 per cent. of the wheat produced in the Prairie Provinces was Marquis, ${ }^{15}$ and the average price received by farmers for the crop of both years was, is, and will be almost exactly two dollars a bushel. ${ }^{16}$ The data for the required calculations together with the results are embodied in the following Table: ${ }^{17}$

\section{Crop Values of Marquis Wheat in Canada}

\begin{tabular}{l|c|c|c|c|c}
\hline Year & $\begin{array}{c}\text { Total crop } \\
\text { of wheat } \\
\text { in the three } \\
\text { Prairie } \\
\text { Provinces } \\
\text { in bushels }\end{array}$ & $\begin{array}{c}\text { Per- } \\
\text { cen- } \\
\text { tage } \\
\text { of } \\
\text { Mar- } \\
\text { quis }\end{array}$ & $\begin{array}{c}\text { Amount } \\
\text { of } \\
\text { Marquis } \\
\text { in bushels }\end{array}$ & $\begin{array}{c}\text { Price } \\
\text { per } \\
\text { bushel }\end{array}$ & $\begin{array}{c}\text { Crop } \\
\text { values } \\
\text { of } \\
\text { Marquis }\end{array}$ \\
\hline 1917 & $212,000,000$ & 80 & $169,600,000$ & $\$ 2.00$ & $\$ 339,200,000$ \\
1918 & $162,000,000$ & 80 & $129,600,000$ & $\$ 2.00$ & $\$ 259,200,000$ \\
\hline
\end{tabular}

To the total given in the last column several millions of dollars should be added for the crop value of Marquis grown in Ontario, Quebec, ete.

From the data at our disposal we may safely draw the conclusion that the crop value of Marquis for the whole

15 Information kindly supplied by Mr. George Serls, the chief Grain Inspector for the Dominion of Canada.

16 Information kindly supplied by Mr. Irvine, Assistant Secretary of the Winnipeg Grain Exchange.

17 The total crop of wheat in the Prairie Provinces for 1917 is that given in the Bulletin of Agricultural Statistics, Ottawa, Jan., 1918, and the crop for 1918 as estimated in September, 1918, at Winnipeg. 
of Canada was in 1917 at least $\$ 310,000,000$, and in 1918 at least $\$ 260,000,000$.

Let us now attempt to estimate the crop value of Marquis in the United States for the year 1917. The data for estimating the crop value of Marquis, in 1917, for the four chief spring-wheat States, together with the results of the calculations, are given in the following Table : 18

Crop Values of Marquis Wheat in the Four Spring-Wheat States in 1917

\begin{tabular}{l|c|c|c|c|c}
\hline & $\begin{array}{c}\text { Total crop } \\
\text { of wheat } \\
\text { in bushels }\end{array}$ & $\begin{array}{c}\text { Per- } \\
\text { cen- } \\
\text { tage } \\
\text { of } \\
\text { Mar- } \\
\text { quis }\end{array}$ & $\begin{array}{c}\text { Amount } \\
\text { of } \\
\text { Marquis } \\
\text { in bushels }\end{array}$ & $\begin{array}{c}\text { Price } \\
\text { per } \\
\text { bush- } \\
\text { el }\end{array}$ & $\begin{array}{c}\text { Crop } \\
\text { value } \\
\text { of } \\
\text { Marquis }\end{array}$ \\
\hline Minnesota & $57,965,000$ & 46 & $26,663,900$ & $\$ 2$ & $\$ 53,327,800$ \\
N. Dakota & $56,000,000$ & 43 & $24,080,000$ & $\$ 2$ & $\$ 48,160,000$ \\
S. Dakota & $52,024,000$ & 43 & $22,370,320$ & $\$ 2$ & $\$ 14,740,640$ \\
Montana . & $17,963,000$ & 45 & $8,083,350$ & $\$ 2$ & $\$ 16,166,700$ \\
\hline Totals . & $183,952,000$ & & $81,197,570$ & & $\$ 162,395,140$ \\
\hline
\end{tabular}

From the foregoing Table, it is clear that the crop value of Marquis for the year 1917, in the four chief springwheat States alone, amounted to the large sum of $\$ 162$,000,000. But Marquis in 1917 was also grown on many acres in several other States. Making allowance for this, the crop value of Marquis for the United States as a whole, in 1917, was upwards of $\$ 170,000,000$.

18 The totals of the crops of wheat in the four States are as given in the December Monthly Crop Report, Washington, 1917, p. 121. The percentages of the whole crop contributed by Marquis is given in the August Monthly Crop Report, 1918, p. 95. The exact prices per bushel, which vary about $\$ 2$, are given in the December Monthly Crop Report, 1917. 
Let us now turn to the present year, 1918. On September 1, the spring-wheat crop was forecasted at 342,855,000 bushels of which about $257,000,000$ bushels were forecasted for Minnesota, the two Dakotas and Montana. ${ }^{19}$ These four States were also estimated to produce 15,050,000 bushels of winter wheat ${ }^{20}$ making with the spring wheat a grand total of $2 \tau 2,000,000$ bushels. It has been estimated, howerer, that at least 65 per cent. of the total wheat crop of these four States consists of Marquis. ${ }^{21}$ The amount of Marquis produced in the four chief springwheat States, therefore, is about $177,000,000$ bushels. At the average fixed price of $\$ 2.00$ a bushel, the crop value of this mass of wheat amounts to $\$ 354,000,000$. But, this year, spring wheat has been grown in other States to the extent of $86,000,000$ bushels; and of this wheat a very large proportion has been Marquis, probably one-half. Making allowance for this, it appears safe to say that the crop value of Marquis for the United States as a whole, in 1918, is upwards of $\$ 370,000,000$.

One further calculation only remains to be made, namely, the crop value of Marquis in the whole springwheat region of Torth America for the years 1917 and 1918. To make this calculation, all we need to do is to add the totals already obtained for Canada and the United States. The following Table contains these totals and their summations:

Crop Value of Marquis in North America

\begin{tabular}{c|c|c|c}
\hline & Canada & United States & Total Value \\
\hline 1917 & $\$ 339,200,000$ & $\$ 170,000,000$ & $\$ 509,200,000$ \\
1918 & $\$ 259,200,000$ & $\$ 370,000,000$ & $\$ 629,200,000$ \\
\hline
\end{tabular}

19 October Monthly Crop Report, Washington, 1918.

20 August Monthly Crop Report, Washington, 1918.

21 Estimate sent to the writer by Mr. Carleton R. Ball, of the Office of Cereal Investigation, Washington. 
From the Table it becomes evident that the total crop value of Marquis wheat in North America was upwards of $\$ 500,000,000$ in 1917 and upwards of $\$ 600,000,000$ in 1918. It is to be doubted whether any other single variety of wheat ever had such a high crop value as this.

Marquis wheat, as we have seen, originated in Canada and was first grown there on a large scale. It is interesting to note, however, that this year, 1918, more Marquis has been grown in the United States than in Canada. Whereas the Canadian crop of Marquis, owing to adverse weather conditions, was only about $130,000,000$ bushels, that of the United States was upwards of $180,000,000$ bushels. As a consequence, the crop value of Marquis in the United States will this year, for the first time, considerably exceed that in Canada.

The years 1917 and 1918 are war years, and the price of wheat is abnormally high. Soon after peace is declared, there can be little doubt that the price of wheat will decline and the yearly crop value of Marquis suffer accordingly. However, Marquis is still increasing in popularity with American farmers, and the acreage devoted to spring wheat in North America is still being considerably extended. Even should pre-war prices again come to prevail, the annual crop value of Marquis will probably not fall below an average of $\$ 300,000,000$ a year for some years at least.

\section{The Increased Wealth Brought by Marquis to the United States}

We shall now endeavor to make an estimate of the increased wealth which has accrued to the United States through the replacement of the older lesser-yielding varieties of wheat, such as Bluestem, Fife, and Velvet Chaff, by the newer variety from Canada. 
Let us first consider the year 1917 and limit our inquiry to the single State of Minnesota. To what extent did Minnesota benefit financially in 1917 through growing Marquis wheat? The answer to this question can be obtained from the following data for which we are indebted to the Bureau of Crop Estimates of the United States Department of Agriculture:

DATA FOR MINNESOTA

Total crop of wheat in $1917 \ldots \ldots 57,965,000$ bushels. $^{22}$

Average price of wheat per bushel.......2 dollars. ${ }^{23}$

Percentages of the Total Crop for the Chief Wheat Varieties ${ }^{24}$

\begin{tabular}{c|c|c|c|c|c|c|c}
\hline & $\begin{array}{c}\text { Mar- } \\
\text { quis }\end{array}$ & $\begin{array}{c}\text { Vel- } \\
\text { vet } \\
\text { Chaff }\end{array}$ & $\begin{array}{c}\text { Blue- } \\
\text { stem }\end{array}$ & $\begin{array}{c}\text { Du- } \\
\text { rum }\end{array}$ & Fife & $\begin{array}{c}\text { Win- } \\
\text { ter }\end{array}$ & Other \\
& $\begin{array}{r}\text { Per } \\
\text { cent. }\end{array}$ & $\begin{array}{c}\text { Per } \\
\text { cent. }\end{array}$ & $\begin{array}{c}\text { Per } \\
\text { cent. }\end{array}$ & $\begin{array}{c}\text { Per } \\
\text { cent. }\end{array}$ & $\begin{array}{c}\text { Per } \\
\text { cent. }\end{array}$ & $\begin{array}{c}\text { Per } \\
\text { cent. }\end{array}$ & $\begin{array}{c}\text { Per } \\
\text { cent. }\end{array}$ \\
\hline $1917 \ldots \ldots$ & 46.0 & 26.0 & 18.0 & 3.0 & 3.0 & 3.0 & 1.0 \\
$1914 \ldots \ldots$ & 3.0 & 30.0 & 52.0 & 2.0 & 7.0 & 2.0 & 4.0 \\
\hline
\end{tabular}

Yield of the Chief Wheat Varieties in Bushels per Acre ${ }^{25}$

\begin{tabular}{l|c|c|c|c|c|c|c}
\hline & $\begin{array}{c}\text { Mar- } \\
\text { quis }\end{array}$ & $\begin{array}{c}\text { vel- } \\
\text { Chaff }\end{array}$ & $\begin{array}{c}\text { Blue- } \\
\text { stem }\end{array}$ & $\begin{array}{c}\text { Du- } \\
\text { rum }\end{array}$ & Fife & $\begin{array}{c}\text { Win- } \\
\text { ter }\end{array}$ & Other \\
& Bush. & Bush. & Bush. & Bush. & Bush. & Bush. & Bush. \\
\hline $1917 \ldots .$. & 17.2 & 16.0 & 14.0 & 15.5 & 15.0 & 20.0 & 14.0 \\
\hline
\end{tabular}

Let us now proceed with our calculation. Since 46 per cent. of the $57,965,000$ bushels of wheat produced in Minnesota in 1917 was Marquis, Marquis contributed to the total wheat crop of the State $26,66.3,900$ bushels.

Now let us suppose that the percentages which each 22 and 23 December Monthly Crop Report, 1917, Washington, p. 121. 24 and 25 August Monthly Crop Report, 1918, Washington, p. 95. 
variety of wheat contributed to the crop of Minnesota in 1917 was the same as it was in 1914 , i. e., at the time when Marquis had only just made its advent in the State, and let us distribute the $26,663,900$ bushels which Marquis produced in 1917 among all these varieties in accordance with these 1914 percentages. Then of the 26,663,900 bushels :

Marquis .....taking 3 per cent. will receive 799,917 bushels Velvet Chaff. .. taking 30 per cent. will receive $7,999,170$ bushels Bluestem .....taking 52 per cent. will receive $13,865,228$ bushels Durum ......taking 2 per cent. will receive 533,278 bushels Fife ........taking 7 per cent. will receive $1,866,473$ bushels Winter Wheat. .taking 2 per cent. will receive 533,278 bushels Other Wheat...taking 4 per cent. will receive $1,066,556$ bushels

These masses of wheat, however, were produced by Marquis wheat-plants which had a yield in 1917 of 17.2 bushels per acre. Had equivalent masses of wheat been produced by Bluestem, Fife, etc., these masses would have been smaller, because these varieties in 1917 yielded less than

\begin{tabular}{|c|c|c|c|c|}
\hline & $\begin{array}{l}\text { Wheat } \\
\text { assigned } \\
\text { Bushols }\end{array}$ & $\begin{array}{c}\text { Yields } \\
\text { in } 1917 \\
\text { Bushels } \\
\text { per acre }\end{array}$ & $\begin{array}{l}\text { Adjust- } \\
\text { ments } \\
\text { Bushels }\end{array}$ & Remarks \\
\hline $\begin{array}{l}\text { Marquis .... } \\
\text { Velvet Chaff. } \\
\text { Bluestem ... } \\
\text { Durum ..... } \\
\text { Fife ...... } \\
\text { Winter wheat } \\
\text { Other wheat. }\end{array}$ & $\begin{array}{r}799,917 \\
7,999,170 \\
13,865,228 \\
533,278 \\
1,866,473 \\
533,278 \\
1,066,556\end{array}$ & $\begin{array}{l}17.2 \\
16.0 \\
14.0 \\
15.5 \\
15.0 \\
20.0 \\
14.0\end{array}$ & $\begin{array}{r}799,917 \\
7,441,088 \\
11,285,651 \\
480,570 \\
1,627,738 \\
620,091 \\
868,127\end{array}$ & $\begin{array}{c}\text { no change } \\
\text { decrease } \\
\text { decrease } \\
\text { decrease } \\
\text { decrease } \\
\text { increase } \\
\text { decrease }\end{array}$ \\
\hline Totals .... & $26,663,900$ & & $23,123,182$ & decrease \\
\hline
\end{tabular}


Marquis. Let us find out, therefore, what the masses of wheat just distributed among the various varieties would have been, had they been actually yielded in 1917 by the varieties to which they have been assigned (vide Table).

The difference between the totals just given is $3,540,718$ bushels. We thus see that if, in 1917 , the $26,663,900$ bushels of Marquis had been replaced by wheat from the various varieties in the proportions in which they were grown in 1914, the Mrinnesota wheat erop of 1917 would have been reduced by $3,540,718$ bushels. Instead of its being $57,965,000$ bushels, it would have been $54,424,282$ bushels.

Summing up the results of the foregoing calculation, we may say that the increase in the raising of Marquis wheat in Minnesota in the last three seasons has resulted in a gain in the 1917 crop of $3,5+1,000$ bushels. Taking two dollars per bushel as the average price, we are justified in concluding that the introduction of Marquis wheat into Minnesota brought about a gain in wealth in 1917 of up wards of 7,000,000 dollars.

By making use of the appropriate crop statistics, ${ }^{26}$ and by employing the method of investigation just explained, gains corresponding to that just found for Minnesota, can be found for the two Dakotas.

So far as Montana is concerned, the statistics for the relative contributions of the different wheat varieties to the total crop of 1914 are not available. However, we know that MIontana in 1917 produced 17,963,000 bushels of wheat, of which 45 per cent. or $8,083,000$ bushels was Marquis; and we also know that the estimated yields of the spring-wheat varieties in bushels per acre in 1917 were as follows: Marquis 9.3, Velvet Chaff 7.5, Bluestem 6.5, Durum 9, and Fife 7.5.27 This allows us to conclude 26 and 27 Loo. oit. 
that had Velvet Chaff, Bluestem, and Fife been grown in Montana in 1917 instead of Marquis, the yield of spring wheat would have been lessened by about 1,500,000 bushels. Taking this into consideration, we may assume that the increase in the growing of Marquis in Montana since 1914 caused an increase in the 1917 crop of, let us say, at least 1,100,000 bushels.

Let us now summarize the estimated wealth gained in the four chief spring-wheat States, in 1917, through the increased cultivation of Marquis since 1914.

Gains in Wealth by Growing Marquis in the Four Chief Spring-wheat States

\begin{tabular}{c|c|c|c|c}
\hline & $\begin{array}{c}\text { Total } \\
\text { crop } \\
\text { for } 1917 \\
\text { in bushels }\end{array}$ & $\begin{array}{c}\text { Gain by } \\
\text { growing } \\
\text { Marquis } \\
\text { in bushels }\end{array}$ & $\begin{array}{c}\text { Price } \\
\text { per } \\
\text { bushel }\end{array}$ & $\begin{array}{c}\text { Financial } \\
\text { gain ky } \\
\text { growing } \\
\text { Marquis, } \\
\text { in dollars }\end{array}$ \\
\hline Minnesota & $57,965,000$ & $3,540,718$ & $\$ 2$ & $\$ 7,081,436$ \\
N. Dakota. & $56,000,000$ & $1,619,380$ & $\$ 2$ & $\$ 3,238,760$ \\
S. Dakota. & $52,024,000$ & $3,755,396$ & $\$ 2$ & $\$ 7,510,792$ \\
Montana . & $17,963,000$ & $1,100,000$ & $\$ 2$ & $\$ 2,200,000$ \\
\hline Totals . . & $183,952,000$ & $10,015,494$ & $\$ 2$ & $\$ 20,030,988$ \\
\hline
\end{tabular}

We thus perceive that, through increasing the amount of Marquis grown, from about 4 per cent. in 1914 to about 44 per cent. in 1917, the gain of wealth in the four chief spring-wheat States in 1917 was upwards of 10,000,000 bushels of wheat valued at 20,000,000 dollars. The great campaign which was carried on by American millers and seedsmen in the years 1913 and 1914 for the rapid introduction of Marquis into the spring-wheat region of the United States, has therefore soon borne financial fruit; but it has had a consequence of still greater importance: it resulted in making at least 10,000,000 more bushels of American wheat available for the Allies in the Great War 
at the very moment when the late food crisis attained its climax.

The increased wealth accruing to the United States this year, 1918, through the increase in the sowing of Marquis since 1914, cannot be exactly calculated as the necessary statisties will not be available for some months. However, Mr. Carleton E. Ball, of the Office of Cereal Investigation at Washington, has estimated that Marquis this year will form 65 per cent. of the wheat crop in the chief spring-wheat States and possibly a little more. ${ }^{28}$ We thus see that Marquis is making a gain of about 50 per cent. over 1917 by increased sowing. It is also estimated that this year the United States will produce about 90,000,000 more bushels of spring-wheat than in $1917 .^{29}$ It is certain that a great proportion of these extra bushels will consist of Marquis. Taking all these facts into consideration, one appears to be justified in estimating the gain in wealth in the four chief spring-wheat States in 1918, obtained by increasing the cultivation of Marquis since 1914, at upwards of $15,000,000$ bushels valued at $30,000,000$ dollars.

Any calculation of the full monetary worth of Marquis to the United States should include an allowance for the 4 per cent. of Marquis already grown in the chief springwheat States in 1914 and another allowance for Marquis grown in States other than Minnesota, the two Dakotas, and Montana. These gains should be added on to those already recorded. However, they cannot be calculated as the necessary data concerning them are not available. We shall therefore ignore them and content ourselves with the following conclusion which surely must be a conservative one. Through the replacement of lesser-yielding va-

28 Estimate in a letter to the writer.

29 Monthly Crop Report, Washington, August, 1918, p. 87. 
rieties of wheat, such as Bluestem, Fife, and Preston, by Mrarquis, the wealth of the L'nited States has been increased: in 1917 by upwards of $10,000,000$ bushels of wheat valued at $\$ 20,000,000$, and in 1918 by upwards of $15,000,000$ bushels of wheat valued at $\$ 30,000,000$.

\section{The Increased Wealth Brought by Marquis to Canada}

In order to obtain a general statement of the increased wealth which has been added to western Canada by the introduction of Marquis, we may begin by assuming that the wheat grown on summer fallow (or similarly prepared land) represents half the total yield. ${ }^{30}$ It seems that

30 The phrase similarly prepared land includes (1) new breaking and (2) land on which hoed crops, i. e., potatoes, Indian corn and roots, were raised the previous year. The proportion of summer fallow or its equivalent is greatest in the districts which produce the most wheat, i.e., central and southern Manitoba, central and southern Saskatchewan, and southern Alberta. In those same areas Marquis is grown almost exclusively and in many of the districts it would now be almost impossible to purchase a single car-load of Red Fife. In districts like central Alberta (often ealled northern, but central on the map) where the rainfall is heavier, summer fallowing is much less general but there is a considerable amount of new breaking.

Very generally in western Canada the farm is divided into three gections one of which is sown on summer fallow, another on stubble, while the third is summer fallowed. Thus for all purposes 33.3 per cent. of the land is fallow and 66.6 is available for sowing. Therefore half the acreage sown is on summer fallow. On summer fallow the crop is usually from 50 to 100 per cent. greater than that on stubble, or, in other words, about three-quarters of the crop is produced on summer fallow. From the above considerations it is obvious that the assumption given in the text that the wheat groun on summer fallow (or similarly prepared land) represents half the total yield is a conservative one.

Since summer fallowing is not usually practiced in North Dakota, South Dakota, and Minnesota to the same extent that it is in western Canada, it may be of interest to remark that summer fallowing is found to be advantageous in western Canada for the following 
about 80 per cent. of the wheat grown on summer fallow in the West is Marquis, ${ }^{31}$ and that on summer fallow Marquis yields at least 20 per cent. more wheat in bushels than Red Fife which it has replaced..2 Now let us suppose that we are dealing with a crop of $200,000,000$ bushels, which, as a matter of fact, is less than the average for the last five years. ${ }^{33}$ One half of this, i. e.,

reasons: (1) There is insufficient rainfall to produce a maximum crop with the rain of the current season only. Summer fallowing, by preventing weeds from growing and exhausting the moisture, and by keeping the surface of the ground pulverized and thereby checking evaporation, largely conserves the moisture of the one season and carries it over to the next. (2) The weeds are controlled. On summer fallow the weed seeds at the surface of the soil germinate and then the weeds are killed by cultivation. In this way summer fallowing, in a normal season, practically insures a good crop. On the other hand, sowing on stubble land is somewhat precarious. It costs relatively little to sow on stubble, for such land is easily prepared, whereas summer fallow requires to be worked the whole season. Therefore in good seasons, even if the yield is reduced as compared with summer fallow, stubble sowing is very profitable, if not the most profitable method of farming. However, in bad seasons, stubble farming is sometimes a total failure.

31 Mr. George Serls, the Chief Grain Inspector for the Dominion of Canada, has kindly informed me that, from estimates made during inspections, Marquis forms at least 80 per cent. of the wheat crop of the West. It is therefore only reasonable to conclude that at least 80 per cent. of the wheat crop grown on summer fallow, where Marquis does so well, is Marquis.

32 This is a conservative estimate. Cf. data given in Section $\mathrm{X}$ on Long-period Tests for Earliness and Yield.

33 The average annual wheat crop for western Canada (Manitoba, Saskatchewan, and Alberta) during the last five years has been $233,000,000$ bushels and for the whole of Canada 256,000,000 bushels; but the wheat area for the whole country has increased from 11,015,000 acres in 1913 to $16,080,800$ acres in 1918 and is still being extended, so that it is to be expected that during the next five years the average annual wheat crop will show a considerable increase over that for the last five rears. The area seeded to wheat in western Canada in 1918 was stated by the Dominion Bureau of Statistics on June 12 to be 15,196,300 acres. The rest of Canada, therefore, this year has only 884,500 acres under wheat. The following are the 
100,000,000, will be on summer fallow. Eighty per cent. of this will consist of Marquis, i. e., the Marquis wheat will be represented by $80,000,000$ bushels. If we take 20 per cent. of this as the increase in the crop due to growing Marquis instead of Red Fife, the wealth added to the country owing to the introduction of Marquis would be $16,000,000$ bushels. In unfavorable seasons, when Rust or early frost do much damage, the advantage of the more quickly ripening Marquis over the later ripening Red Fife would be even greater. In the year 1915 the wheat crop attained a record for this country. The final figures, according to Mr. Milner, a former president of the Winnipeg Grain Exchange, were 376,448,400 bushels. ${ }^{34}$ Using the same basis of calculation as before, the additional harvest due to growing Marquis instead of Red Fife in 1915, had Marquis been as widely grown then as now, would have been upwards of $30,000,000$ bushels. As a matter of fact it was probably quite $20,000,000$ bushels. It seems safe to suppose that, from now onwards, the additional harrest, due to growing Marquis instead of other wheats which it has replaced, will be on the average from 16,000,000 to $25,000,000$ bushels per annum. ${ }^{35}$

official figures for the wheat crop for the last five years given in bushels:

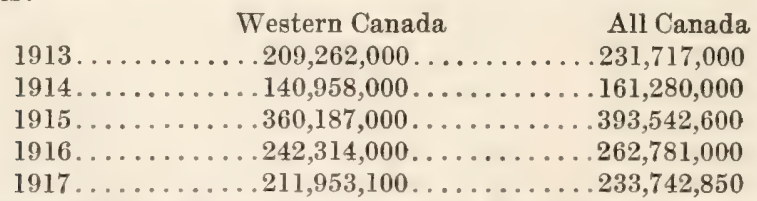

Vide Canada Year Book, Department of Trade and Commerce, Ottawa, 1915, pp. 162-165; 1916-17, pp. 192-193; and the Monthly Bulletin of Agricultural Statistics, Department of Trade and Commerce, Census and Statistics Office, Ottawa, Jan., 1918, pp. 4, 10-12.

$34 \mathrm{~W}$. E. Milner, The President's Address, Eighth Annual Report (new series) of the Winnipeg Grain Exchange, presented to the Annual Meeting held September 13, 1916, p. 24.

35 There can be little doubt that the replacement of Red Fife by 
Canada, according to the Hon. W. J. Hanna, formerly Food Controller of the Dominion, is the most extravagant consumer of wheat of all the countries of the world. The consumption per capita for every man, woman, and child for food purposes of all sorts, including the feeding of animals, has been 9 bushels per annum. ${ }^{36}$ It is therefore clear that the addition to our wheat crop of from 16,000,000 to $25,000,000$ bushels per annum, owing to the discovery and introduction of Marquis, would provide all the bread and other wheat requirements for an additional population in Canada of upwards of 2,000,000 people.

The price of wheat, as every one knows, has varied much in the last ten years but, taking the value of wheat as only 70 cents a bushel, the wealth being added to western Canada through the replacement of other wheats by Marquis is from $\$ 11,200,000$ to $\$ 17,500,000$ per annum; ${ }^{37}$ and just now, under war conditions, this sum must be multiplied by three. ${ }^{38}$ Within a few decades, at this rate, Mar-

Marquis which, owing to its earliness in ripening and its high yield, is more suited to conditions in western Canada than its predecessor, has done much to encourage the breaking of new land on farms already established and also to increase the number of new farms by stimulating the immigration of experienced farmers. This effect of Marquis is imponderable and cannot be expressed in bushels or dollars per annum; but if it could be, no doubt it would add considerably to the statistical estimate of the value of Marquis to this country.

36 The Canadian Food Bulletin, No. 9, Jan. 26, 1918, p. 2. An endeavor is now being made to reduce the human consumption of wheat to 5.4 bushels per capita per annum.

37 The crop in western Canada for the year 1918 has been estimated at $162,000,000$ bushels, i. e., $71,000,000$ bushels below the average for the five previous years. The increment due to the replacement of Red Fife by Marquis has been only 13,000,000 bushels; but, as the price of wheat now averages about $\$ 2.00$ per bushel, this mass of wheat is worth $\$ 26,000,000$. In 1917 the increment was upwards of $16,000,000$ bushels valued at $\$ 32,000,000$.

38 The average price per bushel received by Canadian farmers for the crops each year from 1910 onwards was as follows: 
quis wheat will put into our farmers' pockets an extra gain of hundreds of millions of dollars, an amount of money which would be more than sufficient to pay for all the education given in the Public Schools, the High Schools, the Agricultural Colleges, and the Universities of the whole of western Canada. Even if we take the very conservative estimate of $\$ 15,000,000$ per annum as the increased wealth Marquis is bringing into Canada, and disregard every other consideration, we obtain sufficient evidence to convince ourselves of the amazing success of the Canadian Government in its wheat-breeding experiments. Well may this country be proud of its achierements in this direction and especially proud of Dr. Charles E. Saunders, whose skill and patience triumphed orer all the difficulties that presented themselves and who, in a remarkably short time after his appointment as Dominion Cerealist, gave to the farmer the great gift of Marquis wheat. There are but few men in Canada who can look the whole world in the face and honestly say that by their efforts they have enriched their country by at least $\$ 15$,-

\begin{tabular}{|c|c|c|}
\hline Crops produced in & Price & Crops produced in \\
\hline $1910 \ldots \ldots$ & $\$ 0.75$ & $1914 \ldots \ldots$ \\
\hline $1911 \ldots \ldots$ & $\$ 0.65$ & 1915 \\
\hline $1912 \ldots \ldots \ldots$ & $\$ 0.65$ & 1916 \\
\hline $1913 \ldots \ldots$ & $\$ 0.70$ & $1917 \ldots \ldots$ \\
\hline
\end{tabular}

By an order of the Board of Grain Supervisors of Canada, the price of wheat for the 1917 crop was fixed as follows:

for No. 1 Northern................. \$2.21

for No. 2 Northern................. \$2.18

for No. 3 Northern................ \$2.15

This information was kindly supplied to the writer by Mr. Irvine, Assistant Secretary of the Winnipeg Grain Exchange.

By another order of the Board of Grain Supervisors of Canada, the price of wheat for the 1918 crop (August 26, 1918, until August 31, 1919) was fixed as follows:

for No. 1 Northern............... $\$ 2.241 / 2$

for No. 2 Northern............... \$2.211/2

for No. 3 Northern............... $\$ 2.171 / 2$ 
000,000 a year. But such a man is Dr. Saunders, whose labors exemplify public service at its best. Long may he live to continue his work for the good of Canada and of humanity.

\section{Summary}

The following are some of the more important conclusions which may be drawn from the foregoing pages:

1. Marquis wheat was discovered and introduced by Dr. Charles E. Saunders of the Central Experimental Farm, Ottawa.

2. Marquis is a hard red spring wheat with excellent milling and baking qualities. As compared with Red Fife, it gives a higher yield and on the average is six days earlier in ripening.

3. Marquis was discovered in 1903, first distributed to farmers in western Canada in 1909, and is now, 1918, the dominant spring wheat in both Canada and the United States.

4. In North America the yield of Marquis was: in 1917, upwards of $250,000,000$ bushels having a crop value of 500,000,000 dollars; and, in 1918, upwards of $300,-$ 000,000 bushels having a crop value of $600,000,000$ dollars.

5. In 1917, through the replacement of Red Fife by Marquis, Canada made a gain in wealth of upwards of $16,000,000$ bushels of wheat valued at $32,000,000$ dollars.

6. In 1917, through the replacement of Bluestem, Fife and Velvet Chaff by Marquis, the United States made a gain in wealth of upwards of $10,000,000$ bushels of wheat valued at $20,000,000$ dollars.

7. In 1917, through the replacement of other lesseryielding wheat varieties by Marquis, North America made a gain in wealth of upwards of $26,000,000$ bushels of 
wheat valued at 52,000,000 dollars. During the food crisis of 1917-1918, this mass of wheat was of very great assistance to the Allies in their prosecution of the war.

8. The Government of the Dominion of Canada prepared the way for the discovery of Marquis wheat by establishing the Experimental Farms system in 1886, by encouraging cercal research, and by appointing Dr. Charles E. Saunders, a well-trained scientific man, as Dominion Cerealist in 1903.

9. Marquis wheat was discovered as the result of the application of biological and chemical principles to the problem of breeding a new variety of wheat better adapted than Red Fife for cultivation in the Prairie Provinces of western Canada.

10. The great success of Marquis wheat in the world affords an excellent instance of the benefits which have already been derived from the encouragement given by responsible governments to scientific research. 


\section{CHAPTER IV}

\section{The Origin of Red Bobs and Kitchener}

\section{Introduction}

ONE of the most promising competitors of Marquis is Red Bobs which was selected by Mr. Seager Wheeler at Rosthern, Saskatchewan, in 1910, from an Australian wheat called Bobs. Since Red Bobs is now being widely distributed among the farmers of western Canada and is being tested at various experimental farms and stations, a history of its origin is well worth recording.

\section{Origin of Bobs}

William Farrer ${ }^{1}$ was a leading wheat-breeder in Aus-

1 The following quotation from an article by A. E. V. Richardson, the Agricultural Superintendent of the Victoria Department of Agriculture, is of interest in throwing light upon Farrer's work:

"The outstanding feature in wheat-breeding work in Australia is the remarkable success achieved by that patient and retiring genius, the late William Farrer, of New South Wales, in every branch of wheat improvement.

"A man who could set out as clearly and comprehensively as Farrer (Farrer, The making and improvement of new varieties of wheat for Australian conditions, Agricultural Gazette, N. S. W., Feb., 1898), both as regards the goal toward which he was striving in his work of wheat improvement, and the methods whereby he hoped to reach that goal, and in less than a decade flood the market with varieties like Federation - the most prolific and popular farmer's wheat in the Commonwealth; Bobs and Comeback - of unsurpassed milling excellence; Florence and Genoa-bunt-resisting varieties; and a host of others enjoying a widespread popularity, such as Bunyip, Thew, Bayah, Warren, Genoa, Firbank, Cleveland, Cedar, Jonathan, etc., must have possessed in an unusual degree the insight of genius. It is no exaggeration to say that Farrer has added mil- 
tralia and did much to improve the varieties grown in his native country. By cross-breeding and selection he obtained a fine new wheat with white kernels, which he introduced under the name of Bobs; and he sent about a teaspoonful of the seed to Dr. Charles Saunders, the Cerealist for the Dominion of Canada. Dr. Saunders tested Bobs at Ottawa and then sent some of it to the Indian Head Experimental Farm in Saskatchewan where it was grown in plots for some years. It was found to be a little earlier ${ }^{2}$ than Marquis but less productive. ${ }^{3}$ On account of this lesser productivity and the unfavorable color of its kernels, it was at length discarded.

\section{Importance of the Color of Wheat Kernels}

Even had Dr. Saunders found Bobs to be superior to Marquis in productivity, the white color of its grains would have been fatal to its introduction into western Canada. This is a matter that requires a little explanation. Australia is famed in the British markets for its white wheats but Canada for its red wheats. Now the British buyers are conservative men and suspicious of changes in wheat colors. Hence it has been found advis-

lions sterling to the national exchequer by the creation of Federation wheat. Dr. Cherry estimates the cash value of Farrer's work to Victoria alone during the 1909 season at $£ 250,000$. Since that estimate was framed, the area sown with this popular variety in Victoria has greatly increased, and the benefits have become commensurately greater. Farrer's work was continued by G. L. Sutton, late Wheat Experimentalist of New South Wales, who did a great deal to popularize the Farrer varieties amongst farmers." IWheat Breeding, The Journal of Heredity, March, 1915, pp. 121-125.

2 Dominion of Canada Experimental Farms Report for 1915, p. 877 ; for 1912, p. 123; for 1911, pp. 144-145; for 1910, p. 172. Bobs ripened 1 day earlier than Marquis in 1910, 3 days earlier in 1911, 7 days earlier in 1915, and on the same day as Marquis in 1912.

3 Dominion of Canada Experimental Farms Reports: for 1910, p. 172 ; for 1911 , p. 140 ; for 1915 , p. 877. 
able in Canada to produce wheats for export which are as red as possible, and the grading regulations have been framed in such a way as to discourage the raising of white wheats.

The color of the red and white wheats is due to the color of the bran layer on the exterior of the kernels and not to that of the flour-making mass which the bran layer encloses. There is absolutely no correlation between the color of the bran and the quality of the grain in respect to bread-making. So-called white wheats have a pale yellowish bran layer while red wheats have a darker reddish bran layer. Now the bran layer upon a kernel is more or less translucent, so that the appearance of a grain as a whole is affected by the whiteness or translucency of the interior mass. If the kernel inside the bran layer is horny and translucent, as it is when it contains much gluten, the wheat appears to be relatively dark; but, if the interior is starchy and white, i. e. soft, the wheat has a paler appearance. Both white and red wheats may have the hard horny or the soft starchy interior and thus may appear darker or paler. The difference of shade depending on the difference of the interior only, is significant and important, because starchy wheats are of inferior value for bread-making. In considering a red and a white kind of wheat we may therefore have four possible kinds of grains:

(1) hard red grains which are the darkest of all,

(2) soft red grains which are pale reddish because the interior is white and the whiteness is seen through the translucent reddish bran layer,

(3) hard white grains, in reality a dark yellow, which have a horny interior like hard red grains, 
(4) soft white grains which are very white and which, like soft red grains, hare a starchy interior.

Now hard white grains (3) may be confused with soft red grains (2), although they are radically different. Hence it is that buyers in Great Britain hesitate to purchase white wheat from Canada. They are used to receiving red wheat from this source and, when white wheat samples come into their hands, they are naturally suspicious that they are being offered soft red wheats which are very inferior for bread-making purposes. From these considerations it is clear that the policy of Dr. Saunders in refusing to introduce white wheats into western Canada is thoroughly justified.

IV. The Discovery of Red Bobs by Mr. Seager Wheeler

The facts about to be related concerning the origin of Red Bobs were obtained by the writer during an interview with Mr. Seager Wheeler at his farm at Rosthern during the summer of 1918.

Mr. Wheeler of Rosthern, Saskatchewan, who was an active member of the Canadian Seed Growers' Association and who was engaged in making selections from Dr. Saunders' strain of Early Red Fife and of Preston, heard of Bobs, and, during the winter of 1907-08, secured a ten-pound sample of it from the Experimental Farm at Indian Head. This sample he seeded in the spring of 1908 on one of his special plots by the side of his other varieties of wheat; and, as the Bobs plants grew, he observed that they showed great uniformity and appeared to be free from all admixture. In the autumn the plot gave a yield at the rate of 60 bushels to the acre.

In $1909 \mathrm{Mr}$. Wheeler seeded: (1) a small head-row plot, each row of seeds having been obtained from a single 


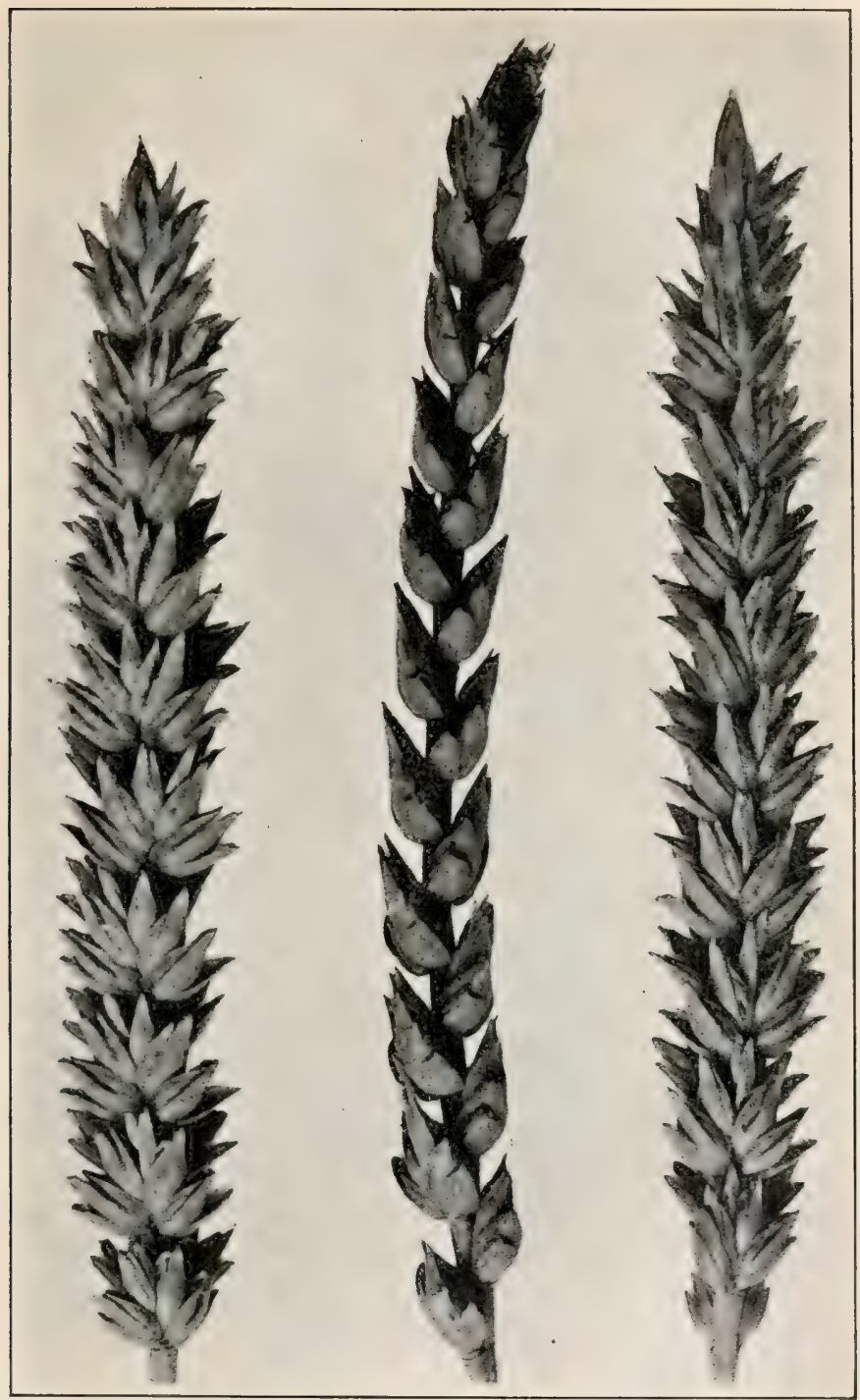

Fig. 41. Typical hearls of Red Bobs wheat, front and side view. Natural size. Courtesy of the Grain Growers' Guide. 

selected head, (2) a 1/4-acre plot, the seeds for which were obtained by mass selection, i. e., from a number of picked heads threshed together, and (3) an increase plot of two or three acres. It is important to note, on account of what follows, that side by side with all these plots of Bobs were similar plots of Early Red Fife and of Preston, and that these three wheats were the only kinds grown by Mr. Wheeler in 1909. Again the Bobs plants appeared to be quite uniform in character.

In 1910, Mr. Wheeler again seeded Bobs in: (1) a head-row plot, (2) a $1 / 4$-acre plot seeded as in the previous year from hand-selected heads, and in (3) an increase plot of several acres. The heads for seeding the $1 / 4$-acre plot were obtained from the $1 / 4$-acre plot and also from the head-row plot of 1909 ; and the increase plot of $2-3$ acres was seeded from the seed resulting from the threshing of the $1 / 4$-acre plot of 1909 . Mr. Wheeler examined all the plants in the $1 / 4$-acre plot as carefully as he could with the result that he discovered that a few of them, less than a dozen, had red grains in all their heads instead of white. Subsequently he detected a few red kernels in the grain threshed from the large increase plot of several acres. This was the very first appearance of any marked variability which Mr. Wheeler had been able to detect since the beginning of his study of Bobs. For the sake of convenience, we shall now call the original Bobs variety White Bobs and the red selection from it Red Bobs. Red Bobs, as we have just seen, was selected from White Bobs in 1910.

In 1911, Mr. Wheeler planted out the seeds obtained from the red-seeded heads of 1910 in head-rows, each head-row containing the seeds of a single head. The plants which came up from these first red seeds at once exhibited a remarkable amount of variability: some were 
awnless like White Bobs, but some were beardy, having short awns at the tip of the head like Red Fife, while others were fully bearded; some were tall growers, some short, and some intermediate; some had open heads and others fairly dense heads; while, in respect to maturity, some were early in ripening and some late. All the grains produced, however, appeared to be red and no white ones were observed. Mr. Wheeler carefully selected heads of each type of plant to serve as seed for the next year.

In 1912 the seed selected in 1911 was planted out in head-rows, and the plants arising from them showed some further variability especially in respect to seed color. All the plants in some head-rows produced nothing but red grains, while, in a few head-rows, some of the plants produced red grains only and some red and white grains mixed. Mr. Wheeler now began to use the name of Red Bobs for the red-grained selection which he wished to multiply.

\section{Red Bobs the Product of a Natural Cross}

The occurrence of a few plants with red grains instead of white in the $1 / 4$-acre plot of 1910 , and the extraordinary variability of the plants produced from them in 1911, strongly suggests that the red-grained plants of 1910 were cross-bred, and that Red Bobs owes its origin to a natural cross which took place in 1909 between White Bobs and one or other of the red wheats Red Fife and Preston which, as we have seen, were grown side by side with White Bobs in all the plots in that vear. It is well known that when two varieties of wheat are crossed artificially, the grains resulting from the cross develop into plants which often differ but little from, or are identical with, one or the other parent, but that in 
the next year the grains produced from the hybrids give rise to a large number of distinct types. The red-seeded Red Bobs plants of 1910 , which apparently differed only in their seed color from White Bobs, correspond to the cross-bred plants or first filial generation in an artificial cross; and the numerous types which were obtained from these red grains in 1911, correspond exactly to the numerous types one frequently obtains in the second filial generation of an artificial cross.

That such natural crosses as that suggested for the origin of Red Bobs do actually occur occasionally under plot conditions, although flower self-fertilization is the rule, has now been sufficiently established by the observations of a number of cerealists. Dr. Charles Saunders was the first on this continent to record such a cross. In 1907, in a Bulletin on the Quality of Wheat, in order to show the value of the chewing test for indicating the gluten value of wheat types, he says: "Some years ago an experiment was tried in order to obtain if possible a natural cross between two varieties of wheat. Red Fife (beardless) and Rio Grande (bearded) were sown mixed in a small plot. When the grain was ripe a few heads of Red Fife, which were borne on rather short straw, were selected, and from these the next season about 200 kernels were sown. Among the plants produced from these seeds, one was found on which the awns were somewhat better developed than is usual in true Red Fife. When some of the seeds of this plant were chewed, it was found that the gluten quality was altogether distinct from, and decidedly inferior to that of Red Fife. In this way it was proved that the plant was a cross, the pollen from the Rio Grande having fallen on the head of Red Fife during the blossoming period in the year previous. As this proof, however, would not perhaps be accepted by other 
observers without confirmation, the seeds from the crossbred plant were sown the following year. They produced mixed types, bearded, partly bearded, and beardless. The seeds as well as the heads showed the influence of the Rio Grande, being, in many cases, larger than those of Red Fife. These observations, of course, completed the proof of the cross-bred nature of the parent plant, and demonstrated the value of the chewing test as a means of distinguishing similar varieties of wheat." 4 NilssonEhle ${ }^{5}$ has shown by experiment that some varieties of wheat are much more liable to natural cross-pollination than others. Smith ${ }^{6}$ found eight natural hybrids in 96 rows of Turkey winter wheat. Leighty, ${ }^{7}$ in 1915 , described four cases of natural crosses between wheat and rye. In 1917 Hayes ${ }^{8}$ recorded that three plants out of fifty taken from nursery plots of Bluestem were natural crosses, as proved from studying their progeny, and that two plants out of 47 selections of Marquis gave progeny with both red and white kernels indicating that they were first generation crosses. The writer visited Dr. Hayes at the University Farm at St. Paul in July, 1918, and saw

4 C. E. Saunders, Quality in Wheat. Bulletin No. 57, Central Experimental Farm, Ottawa, 1907, pp. 9-10. Cf., by the same author, A Natural Hybrid in Wheat, Proc. American Breeders' Association, Vol. I, 1905, pp. 137-138.

$5 \mathrm{H}$. Nilsson-Ehle, Gibt es erbliche Weizenrassen mit mehr oder weniger Selbstbefruchtung? Zeitschrift f. Pfanzensucht, Bd. III, 1915 , pp. 1-6.

6 L. H. Smith, Occurrence of Natural Hybrids in Wheat, Proo. Amer. Breeders' Association, Vol. V, 1912, pp. 412-414.

7 C. E. Leighty, Natural Wheat-Rye Hybrids, Journal of the American Society of Agronomy, Vol. 7, 1915, pp. 209-216.

8 H. K. Hayes, Natural Cross-pollination in Wheat, Journal of American Society of Agronomy, Vol. 10, 1918, pp. 120-122. The citations for Nilsson-Ehle, Smith, and Leighty have been made from this paper. 
for himself several of the natural hybrids and their progeny growing in the plots. He particularly noticed a cross-bred plant produced by a natural cross between Marquis and Bluestem which possessed intermediate characters in the head and straw. In view of the known occurrence of natural crosses between different varieties of wheat when grown side by side in small plots, and in view of facts known in connection with Mr. Wheeler's plots, the author has no hesitation in expressing his belief that Red Bobs owes its origin to a natural cross between White Bobs and Saunders' struin of Early Red Fife or between White Bobs and Preston, one or other of the red wheats having been the male parent.

Professor W. P. Thompson of the University of Saskatchewan has crossed White Bols with Preston and White Bobs with Red Fife, and he has informed the writer that the first generation plants resulting from the crossbred grains in each of the two crosses have heads which cannot be distinguished in general appearance from those of White Bobs, except in the color of the grains which are red instead of white. This fits in very well with the supposition that the few red-grained plants which Mr. Wheeler found in his White Bobs plots in 1910 were actually derived from cross-bred kernels such as those Professor Thompson has produced artificially in the manner described.

Preston is a fully bearded wheat, whereas Early Red Fife is bald except for a few awns at the top of the head. White Bobs and Red Bobs are quite awnless. Since bearded forms appeared after the natural cross in the second generation, it might be supposed that the male parent of Red Bobs was the bearded Preston and not the almost bald Early Red Fife; but such an opinion may 
well be erroneous, for it has been observed by Dr. Charles Saunders ${ }^{9}$ that, when two practically awnless wheats have been artificially crossed, bearded types often occur in the second and later generations. Mr. Wheeler was unable to suggest to the writer which of the two wheats, Early Red Fife or Preston, had supplied the foreign pollen. Perhaps, however, the matter might be decided by making two crosses, one between Thite Bobs and Early Red Fife and another between White Bobs and Preston, and comparing the progeny in the second and third generations with those observed by $\mathrm{Mr}$. Wheeler as the result of the natural erossing. It so happens, as we have seen, that Professor Thompson has already made crosses between White Bobs and Red Fife and White Bobs and Preston. Perhaps, when his studies of these crosses are complete, he will be able to solve the problem of the exact male parentage of Red Bobs with which we are confronted.

\section{The Selection, Multiplication, and Distribution of Red Bobs}

In 1913, Mr. Wheeler sowed seeds of about 60 different types of Red Bobs. A severe hailstorm, on July 28, partially destroyed his crop but served to reveal the fact that some of the types were much better than others in strength of straw.

In 1914, Mr. Wheeler cut down his types to three or four which, except for seed color, most closely resembled the original White Bobs. These mixed strains on a $1 / 4^{-}$ acre plot yielded at the rate of 50 bushels to the acre,

${ }^{9}$ Charles E. Saunders, Wheat Breeding in Canada, Reports of the Winnipeg Meeting of the British Association for the Advancement of Science, 1909; also Dominion of Canada Experimental Farms Reports for 1910 , p. 166. 
whereas Marquis, on a similar plot and under similar conditions, yielded at the rate of 43 bushels to the acre.

In 1915, the seed of Red Bobs, containing three strains, was again sown on a $1 / 4$-aere plot. A certain number of heads of the three types were selected by hand to seed head-row plots the next year and then the rest of the plants were threshed together.

In 1916, Mr. Wheeler again sowed his usual sets of plots with Red Bobs, but unfortunately a severe hailstorm completely destroyed his plants. However, he still possessed about 10 bushels of seed, a sheaf or two, and a few heads which had been held over from the harvest of 1915 , and all this was available for seed the next year. The chicf result of the destruction wrought by the hail was a loss of a whole year in the multiplication of the seed.

In 1917, Mr. Wheeler sowed a five-acre field with Red Bobs containing three types obtained from a bulk threshing. The harvest consisted of 200 bushels of seed and was disposed of to the Grain Growers' Guide. This company has distributed the seed to those who subscribe to its paper in 10, 20, 40, and 60 pound samples, and it is now (1918) being grown by about 500 farmers on about 75 acres of land. Its test under diverse conditions is, therefore, only just beginning to be made.

This year, 1918, Mr. Wheeler is continuing the study of his three strains of Red Bobs, and it is possible that he may erentually select one only for ultimate distribution. The author visited Mr. Wheeler at his farm on the $23 \mathrm{rd}$ of August and spent a whole day with him looking over the plots, collecting the data of the history of his selections, and in discussing his methods of work. The standing crops had a very fine appearance and, in the $1 / 4$-acre plots 
of Red Bobs, Marquis, and Kitchener (his selection from Marquis), the first-named certainly appeared by its yellower color to be some days earlier than the other two.

\section{Red Bobs at the University of Saskatchewan}

After selecting Red Bobs in 1910, Mr. Wheeler sold some of his White Bobs to Mr. George Harvey, a neighboring farmer, who showed a sample of the harvest which it yielded at the Rosthern Seed Fair in the winter of 1912-13. The exhibit won a first prize. Professor Bracken, of the Field Husbandry Department of the University of Saskatchewan, who was acting as a judge at the Fair, took home a sample of the prize White Bobs and sowed it in one of the University plots in the spring of 1913. When the harvest had been secured, he searched the bulk threshing and found a few red kernels like those obtained by Mr. Wheeler in 1910. These red kernels were planted out in 1914 in foundation plots, and they gave rise to various wheat-plant types, some of which were bald, some bearded, ete., resembling those which had been obtained by MIr. Wheeler from his first red grains in 1911. Since 1914, Professor Bracken has been engaged in selecting the most desirable of the types and in discarding those which are not fixed. In 1915 he sowed centgener plots, each little square of ground being seeded with the seer obtained from the heads of a single plant of the previous year. The harvest of each centgener plot was subjected to a bulk threshing, and the grain resulting was sown in 1916 in a multiplier plot. Each multiplier plot consisted of two rows, 100 links long, equal to an area of $1 / 500^{-}$ acre. The harrest of each multiplier plot was subjected to a bulk threshing, and the grain resulting was sown in 1917 upon a $1 / 100$-acre plot. The grain obtained from 
each 1/100-acre plot was again sown in 1918 upon a $1 / 100$-acre plot, and plots of this size are to be continued for five years so that for each strain being tested reliable results may be obtained in respect to yield, earliness, milling and baking qualities, etc.

From single plants grown in 1914 from red grains, Professor Bracken has now selected twelve strains for further study. From the records which he kindly showed to the writer, it appears that some of these strains ripen their grains about the same time as Marquis, some later than Marquis and some as much as ten days earlier. Four of the strains yielded less than Marquis per acre and eight more than Marquis. Elaborate milling and baking tests were carried out in 1917, and some of the strains passed these tests in a very satisfactory manner.

In 1918 , increase plots of $1 / 8$-acre were sown in order to obtain enough seed to make tests upon various types of soil in different parts of the Province of Saskatchewan.

In the winter of 1911-15, Mr. Wheeler gave to Professor Bracken's Department of Field Husbandry about 40 strains of his Red Bobs, and these were sown at the University Farm in 1915. None of these strains were sown in 1916, two in 1917 and seven in 1918. Some of Mr. Wheeler's strains of Red Bobs are therefore now being tested alongside of Professor Bracken's red-seeded strains of White Bobs. Professor Bracken has now about 100,000 red-seeded plants in his plots, and it seems very likely that one or more new wheats of considerable value to agriculture will ultimately be derived from them. There can be no question but that all the various tests to which they are being subjected are being carried out in the most exact and thorough manner. 


\section{Description of Red Bobs}

Red Bobs is a hard red spring wheat. Its heads are absolutely awnless and of a compact type, the spikelets in a good year being well filled with grains from the bottom to the top of each head. The heads are very upright with little or no tendency to lean, and the straw is very strong, upright, and yellow. The chaff is white or light yellow, lighter than that of Marquis. The upright tendency allows the heads to lie closely in the sheaf with little or no waste. On the average, on Mr. Wheeler's farm, Red Bobs has been a week earlier in ripening than Marquis since 1912 inclusive, and it has yielded a little more than Marquis each year. In 1917 Marquis yielded 40 bushels to the acre and Red Bobs 53. This, however, is an extreme difference in the yield of the two varieties. The grains are of a good red color, short and rounded, and they give a good weight per measured bushel. Their baking and milling qualities are about equal to those of Marquis. The most remarkable point about Red Bobs, as grown on Mr. Wheeler's farm, is the combination of earliness and yield. Mr. Wheeler feels that this new variety, owing to its combination of earliness, high yield, high baking and milling qualities, and the characters of its head and straw, has no equal. An absolute decision of its merits, however, can only be arrived at after it has been tested under diverse conditions for a series of years.

\section{A Visit to Mr. Wheeler's Farm}

A brief note may here be added of a personal nature. The author, as already remarked, visited Mr. Seager Wheeler at his farm on August 23, 1918; and there spent a very happy day in his company, looking over his plots, 


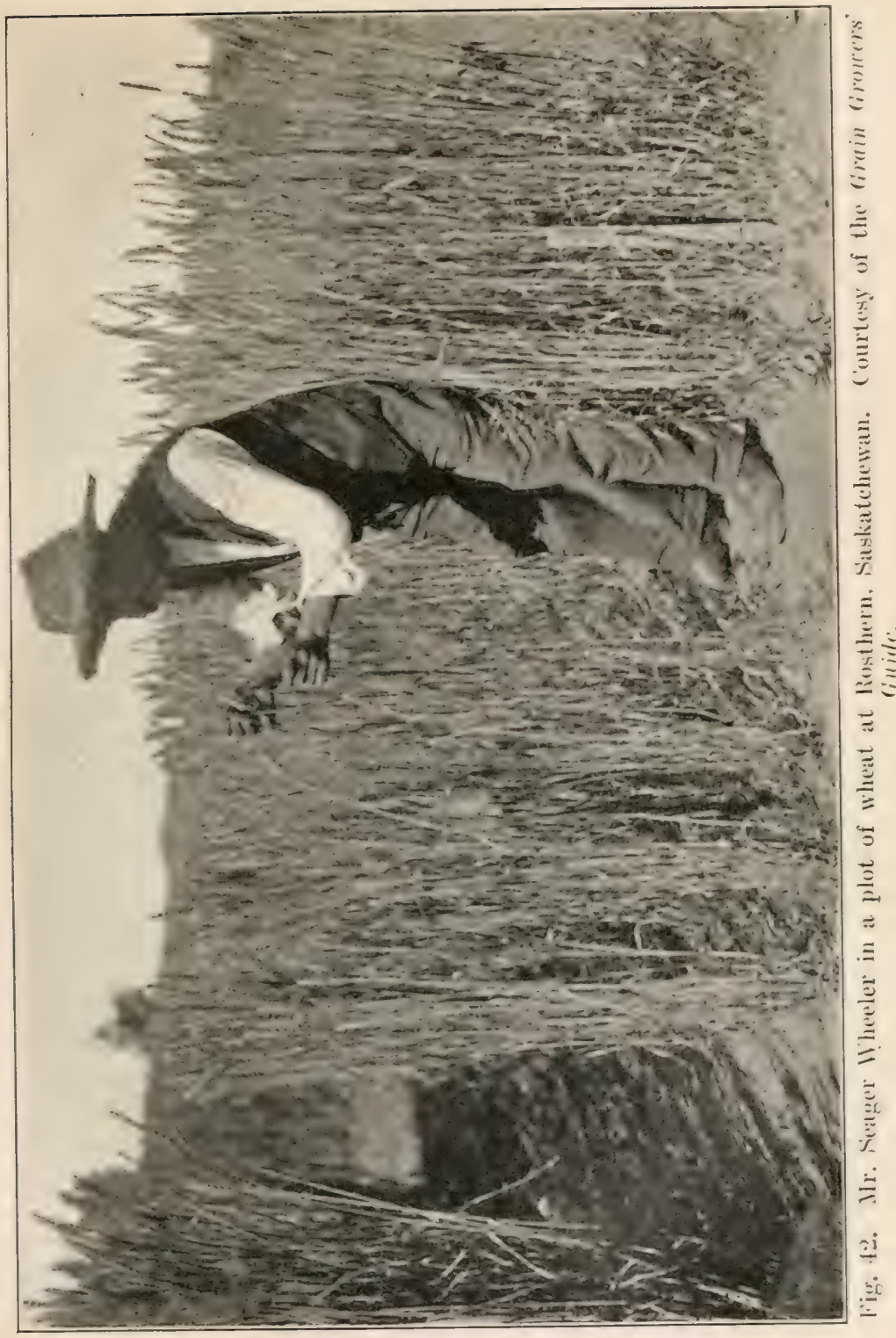



collecting the data of the history of his selections, and in discussing his methods of work. The crops were in the most interesting condition, fast ripening and some ready to cut. The three chief kinds of wheat in the head-row plots and the only ones in the $1 / 4$-acre plots were Marquis, Kitchener, and Red Bobs, and it was upon these that Mr. Wheeler was evidently concentrating his chief attention; but he was also testing three winter wheats, namely Kanred which originally came from Kansas, a selection of his own of Turkey Red, and Winter-Spring, a wheat which originated on his farm in an uncertain manner. Mr. Wheeler was not confining his attention to wheat only, for he was making selections of oats, barley, potatoes, clovers, alfalfa, brome-grass, and western rye-grass; and in his plots were to be seen rows of soy-beans and corn which, however, do not as a rule grow well so far north and were this year a partial failure. His smaller plots, in the garden by the side of his house, were protected by trees and hedges of Russian poplar, etc., which had been planted in rows so as to form wind screens.

Mrr. Wheeler proved an admirable guide and, withal, unassuming, courteous, ready to answer all the numerous questions of his visitor, and also eager to receive any information bearing upon his own work. As he passed from plot to plot, pointing out the qualities of the plants in each, it became evident that he was whole-heartedly absorbed in the task of raising new and improved cereals; and, quite unconsciously, in his conversation and manner, he exhibited an otherworldliness to a degree not often met with in such practical men as farmers. The writer could not help but feel that there was uppermost in Mr. Wheeler's mind not the thought of monetary reward but the hope of originating something of high value to western agriculture. 


\section{A Biographical Note}

Mr. Seager Wheeler was born in the Isle of Wight. His father and uncles were fishermen at Black Gang, a place once famous for the smuggling that went on there. He attended the National School at Ventnor which he left when eleven years old after passing through all the grades. He then worked at the W. H. Smith bookstall at Ventnor Station. A few vears later, in $\mathbf{1 8 8 5}$, he crossed the ocean and came out to Saskatoon where he worked on his uncle's farm for three vears. In 1888 he took up a homestead a few miles north of Saskatoon, and in 1897, Queen Victoria's Jubilee Year, removed to his present farm at Rosthern. Mr. Wheeler has thus been associated with western Canada for 33 years.

Mr. Wheeler began to make selections of cereals and potatoes on his own initiative about the year 1900 but not in a very systematic manner. In 1904, he became an active member of the Canadian Seed Growers' Association, and then undertook the selection of seed according to definite rules. At the same time, he commenced to study individual plants in small seed-plots and to sow head-rows. At first he made selections from Preston, a wheat still grown on many farms at Rosthern, and ther selections from Dr. Saunders' strain of Early Red Fife. He procured a sample of White Bobs for sowing in 1908, and a sample of Marquis for sowing in 1911.

In 1911 he won his first international prize for the best bushel of hard red spring wheat at the New York Land Show with Marquis; and he won similar prizes with Marquis in 1914 and 1915 . In 1916 he also won the international prize but, on this occasion, not with Marquis but with Kitchener, a selection from Marquis. In 1918, for the fifth time, he carried off the international prize, 
but whether he won it with Marquis or Red Bobs is uncertain. ${ }^{10}$ He selected Red Bobs from White Bobs in 1910, and Kitchener from Marquis in 1911. As an active member of the Canadian Seed Growers' Association, he has supplied to other farmers a considerable amount of pure seed of Marquis, Kitchener, and Red Bobs. He has also been much in demand as a judge at Seed Fairs and in standing crop competitions. His stimulating influence has done much to forward the best interests of agriculture in western Canada. When one considers the very small amount of schooling which $\mathrm{Mr}$. Wheeler received as a boy, one cannot help feeling surprise at the successes which he has achieved in the difficult task of plant-breeding. However, he is a born observer, and has remarkable natural ability in distinguishing slight differences in cereals and other plants. There can be no doubt that his selection of Red Bobs from White Bobs was a fine piece of work, such as would be highly creditable to any plant breeder; and the reputation which he has thereby achieved has been well merited.

\section{Kitchener}

Kitchener is a selection from Marquis made by Mr. Seager Wheeler in 1911. The year 1911 was the first in which Mrr. Wheeler grew Marquis and he naturally paid a considerable amount of attention to it. One plant in a plot of Marquis stood out from all the others as a distinct type. He therefore pulled it up by the roots and stored it until winter. Each of the four or fire heads was then rubbed out in the hand separately, and the grains from each head were sown in head-rows in a plot in 1912. The year 1912 was very wet, so much so that 10 Tide Chapter III, Section IX, on Prizes Won by Marquis. 
the grains of some of Mr. Wheeler's wheats sprouted from the heads standing in the fields; but Kitchener did not do this. In that year, Kitchener gave a better result than the other strains of Marquis in point of uniformity, in the color, shape, and size of the grains, and in apparent yield. In 1913 a hailstorm destroyed many of Mr. Wheeler's plants. All the soft-strawed and bearded wheats such as bearded strains of Red Bobs, Preston, and some other wheats, were dashed to the ground. Kitchener, however, stood the test well, even better than Marquis.

Kitchener, Mr. Wheeler feels, has the finest straw of any wheat, for it is not only strong but also very elastic. It ripens about the same time as Marquis, occasionally perhaps a little later, and is later than Red Bobs, Ruby, and Prelude. In 1914 a sheaf of it won an international prize at Denver, Colorado; and in 1915 a quarter of an acre hand-selected seed plot yielded at the rate of 80 bushels to the acre, at about the same rate as the yield of Marquis on Mr. Wheeler's farm in 1911. In 1916 Kitchener won the sweep-stake for the best wheat at the International Soils Products Exposition at El Paso, Texas. In 1917, one field plot yielded 63 bushels to the acre and another 50 bushels. It is evident that the yielding qualities of Kitchener under field conditions at Rosthern are very high. Kitchener is now distributed to a number of farmers in the three western provinces, and it has also been grown in Ontario where its yield has been excellent. In the south and southwest parts of the Prairie Provinces, where it is dry, and where Red Fife is grown in preference to Marquis on account of its longer straw, Kitchener probably has a future owing to superiority in length and strength of straw. It will doubtless have its day for a little while at least in some places.

Kitchener, like Marquis, is not absolutely arnless, and 
it has a solid compact head, and strong straight straw. Its grains as compared with those of Marquis are slightly larger and smoother. The grains are the smoothest known to Mr. Wheeler. 


\section{CHAPTER V}

\section{The Wild Wheat of Palestine}

\section{The Importance and Antiquity of Agriculture}

For some hundreds of thousands of years primitive man was a hunter who knew nothing of either cultivated plants or domesticated animals. Towards the end of the long Stone Age, the way to civilization was opened throngh the introduction of agriculture and through the taming of the dog, the ox, the sheep, the pig, the horse, and other denizens of the woods and plains.

The cultivation of plants and the breeding of animals for food greatly diminished the danger of starvation, and enabled primitive man to give up his nomadic habits and to live in villages. The grouping of families together in settled communities led to the development of an ever more complex social existence and consciousness with the result that there have been differentiated such remarkable social organisms as those represented by France, Italy, the United States, and Great Britain, with their dense populations, their innumerable towns and cities, their complex civic life, their public buildings, their literatures, their laws, their art, their science, their music, their manufacturing machinery, and their wonderful means of communication and transportation. Without the discovery and introduction of agriculture by primitive man it is certain that not one of the world's great cities, nor even a town of one thousand inhabitants, could ever have come into existence. 
Settled communities based on agriculture, as we know from ancient records, were already established many thousands of years ago. A glimpse into the life of one such community is given us by an inscription upon an obelisk set up by Mannichtousan, King of Sis, who lived near Susa about one hundred miles north of the mouth of the Euphrates. The obelisk in question was set up between 1000 B. с. and 3500 B. C., and the inscription upon it records the price of a sale of land. The price of the land was fixed by the value of the crop. The king bound himself to nourish, clothe, and protect the serfs and slaves who were attached to the estate and who were obliged to cultivate it. Near the place where the obelisk was discovered, the accumulated refuse was found to be fifty feet deep. The King of Sis evidently mled over a community which had advanced a long way in the cultivation of the soil and in general civilization. ${ }^{1}$

\section{The Antiquity and Origin of Wheat}

Archrologists have discovered wheat in the rubbish heaps of the lake dwellings of both Switzerland and Italy, so that we have the clearest evidence that this cereal was cultivated by prehistoric man. Unger found wheat in a brick of the pyramid of Dashur in Egypt, to which he assigned the date 3359 B. c.; and the Chinese grew wheat as long ago as 2700 в. с. ${ }^{2}$ The ancient civilizations of Babylonia, Egypt, Crete, Greece, and Rome were undoubtedly based on wheat as one of the principal food plants.

Wheat has been found in the sarcophagi of ancient

1 G. F. Scott Elliott, Prehistoric Man and His Story, London, 1915 , p. 216.

2 Alphonse de Candolle, Origin of Cultivated Plants, London, 1884, p. 355 . 
Egyptian mummies. It is still currently reported that this mummy wheat, after being sown, has been observed to germinate; but there is no truth whatever in this story. Careful experiment has demonstrated that all real mummy wheat has entirely lost its vitality. The oldest tombs containing wheat belong to the First Dynasty and are about 6,000 years old.

The ancients, who knew nothing of the evolution of man and of his slow passage to civilization through the Age of Stone and the Age of Bronze, attributed the origin of wheat to supernatural agency. The Chinese regarded wheat as a direct gift of heaven. The Egyptians believed its introduction to have been due to Osiris, and the Greeks to Demeter and Tryptolemus.

According to Grecian mythology, Persephone, the daughter of the goddess Demeter, was carried off by Hades; whereupon Demeter visited the earth and sought her child far and wide. On the tenth day of her search, she learned the truth from the all-seeing Sun; and so angry did she become with Zeus for having permitted the outrage that, in her wrath, she made the earth barren, so that the mortals living upon it were threatened with destruction by famine. At last a compromise was effected and it was arranged that Persephone should spend twothirds of the year with her mother and one-third with her husband. On returning to Olympus, Demeter left to mankind the gifts of wheat and of agriculture, as a token of her grateful recollection for the generous treatment she had received upon the earth. She then sent Tryptolemus the Eleusinian round the world in her serpentdrawn chariot to diffuse the knowledge of agriculture and of the blessings which accompany it, such as the settlement of fixed places of abode, civil order, and wedlock. Temples were raised to Demeter who was henceforth regarded 
THE WILD WHEAT OF PALESTINE 281

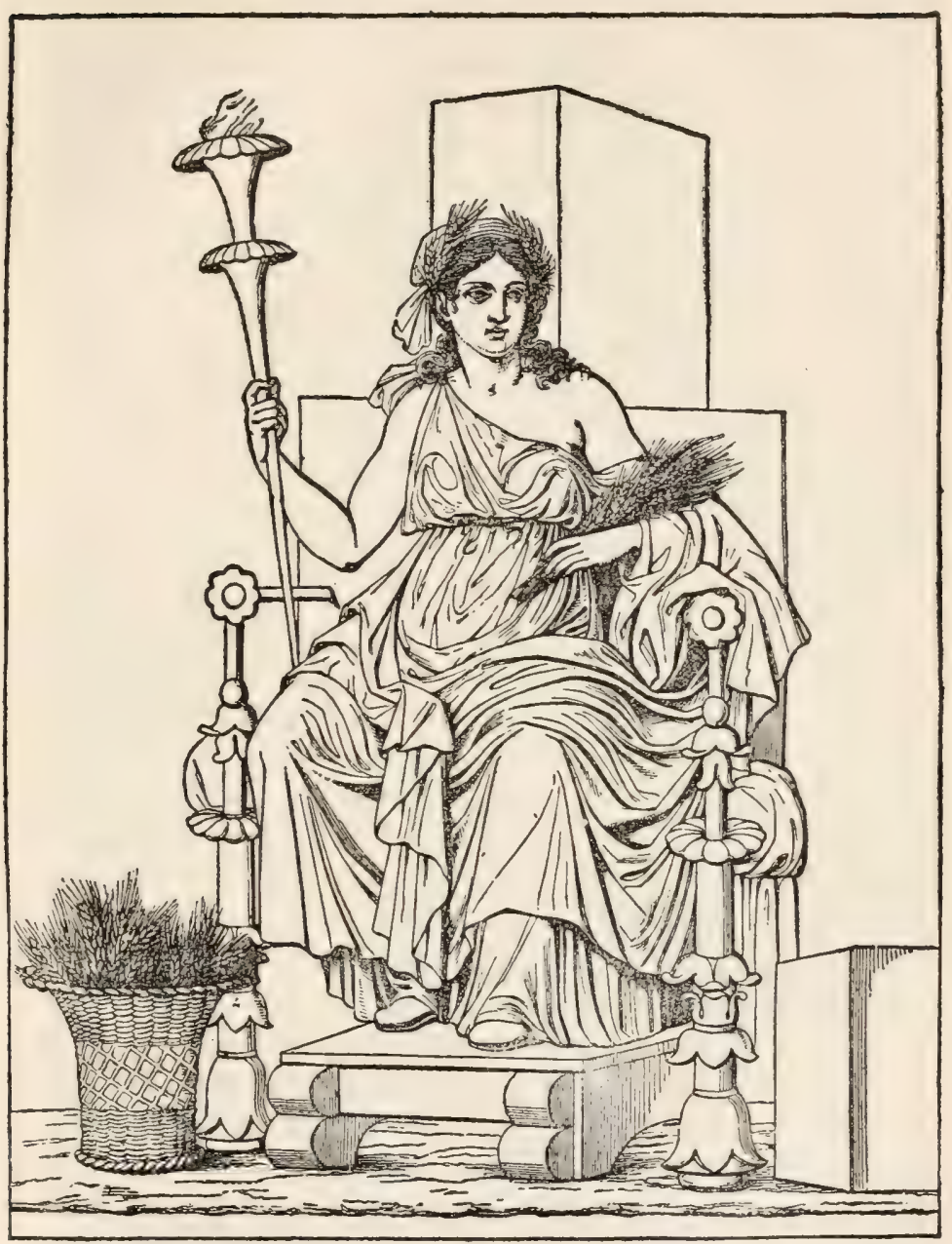

Fig. 43. Demeter enthroned. From a painting found at Pompeii, Naples.

as the goddess of agriculture; and the most ancient seats of her worship were Athens and Elensis where the Rharian 
plain was solemnly plowed every year in memory of the first sowing of wheat. Among the offerings dedicated to her by her votaries were fruit and honey-comb, the cow and the sow, the latter as emblems of productivity. Among her attributes were ears of wheat.

At Rome in B. C. 496 there was a drought. The Sibylline Books were therefore consulted and, as a result, the cult of Demeter was introduced into Italy. The Greek name Demeter was changed by the Romans to Ceres, ${ }^{3}$ and a temple was raised to the goddess on one of the seven hills of Rome in в. с. 490. The worshipers of Ceres in Italy were almost entirely plebeian, and they annually celebrated the festival of the Cerealia or games introduced at the founding of the temple. One fostival was held in April and another was held in August. At the latter, after fasting for nine days, the women, clothed in white and adorned with crowns of ripe ears of wheat, offered to the goddess the first-fruits of the harvest. The worship of Ceres was maintained in its purest form in the country. Here the people of the soil, before the beginning of harvest, offered to the goddess of agriculture a sow (porca præcidanea) and dedicated to her the first cuttings of the wheat fields (præmetium).

At Pompeii, the City of the Dead, which was buried in ashes during the eruption of Vesuvius in A. D. 79, there have been preserved to us some of the world's greatest treasures in art and archrology, and among them are two mural paintings of the goddess of agriculture. In one of them (Figure 43), the artist has represented her as full of

3 Ceres may have been originally a native Italian deity whose name came from creare, to create, and who presided over or represented the generative powers of nature. If so, she was replaced by Demeter when the cult of the Greek goddess was introduced into Italy. $C f$. W. W. Fowler, The Roman Festivals of the Period of the Republic, London, 1908, pp. 73, 181. 
dignity seated upon a throne: her head is crowned with a wheaten garland; in her right hand she bears a torch; upon her left arm reclines a sheaf of wheat, while her relation to the cereal she is supposed to have introduced is further emphasized by a basket of wheat which stands on the ground at her feet. In the other painting, the goddess is represented to us in a standing posture; but again she wears a wheaten crown, while she bears a torch in her right hand and ears of wheat in her left. ${ }^{4}$

The people of ancient Italy, notwithstanding their prayers to Ceres, found that their wheat and other cereal crops were often affected by Rust; and mention of the disease is made in the writings of Aristotle, Theophrastus, Strabo, Varro, Columella, Ovid, and Pliny. Pliny states that it was "the greatest pest of the crops." The Romans believed in a Rust-god whom they called Robigus, and they held that he had power to ward off the rust disease. On the twenty-fifth of April, therefore, at the time in each year when the rust usually attacked the wheat, they celebrated a feast called the Robigalia with the object of propitiating Robigus. The Quirinal flamen presided over the ceremony, and the procession marched out from Rome to the lucus Robigi, situated at the fifth milestone along the Claudian Way. There, in the sacred grove, before a erowd clad in white togas, the priest offered up a prayer to the stern Rust-god, imploring him to spare the crops of Ceres, a libation of wine was poured upon the altar, incense was thrown into the flames, and the entrails of a sheep and of a dog were placed upon the altar and burnt. The dog was reddish, this color being symbolical of the pest to be avoided. Ovid, once, when re-

$4 \mathrm{Cf}$. W. H. Roscher, article on Ceres, Lexicon, Leipzig; also H. T. Peck, articles on Demeter and Ceres in Harper's Dictionary of Classieal Literature and Antiquities, New York, 1896. 
turning to the capital from the neighboring town of Nomentum, met the Robigalian procession by chance, and it is to his pen that we are indebted for an account of the rites which were performed by the priest. ${ }^{5}$

Wheat, rye, barley, oats, millet, rice, and maize are collectively designated as cereals. It is of interest to note that the word cereal riginally meant something pertaining to Ceres, the goddess of agriculture. It is thus clear that when we speak of cereals, we employ a term which was brought into being and shaped into usefulness by the worshipers of the gods and goddesses of Italy some 2,500 years ago.

The besom of science has swept away many of the superstitions of the past, even stretching to high Olympus and removing the gods and goddesses from their seats. When considering the origin of wheat, we no longer think of Osiris and Ceres but seek to guide our steps into the way of truth with light from the lamp of the now thoroughly well established doctrine of evolution. Our present biological knowledge leads us to believe that the wheat now in cultivation was formerly derived from one or more species of wild grass-plants which grew somewhere in Asia, and that the first wheat-grower was a man or woman who lived toward the end of the long Stone Age. The Palæolithic Period or Older Stone Age was coincident with the Great Ice Age, and there is no reason to believe that palæolithic man knew anything of agriculture. The much shorter Neolithic Period or Newer Stone Age was passed through subsequently to the disappearance of the ice. The remains of neolithic man seem to prove that the growing of wheat was associated with his development. Mr. Scott Elliott after discussing the

5 Cf. A. H. R. Buller, The Fungus Lore of the Greeks and Romans, Transactions of the British Mycological Society, 1914, pp. 30-31. 
archæological evidence upon which his conclusion is based, states that " the best guess as to the date of the first harvest is perhaps between 15,000 в. с. and 10,000 в. с." 6

\section{The Prototypes of Cereals}

Certain wild species of barley, oats, and rye are known, which may reasonably be considered as the prototypes or ancestors of their cultivated relatives. Thus Hordeum spontaneum, a wild barley, is regarded as the wild form of Hordeum distichon, the two-rowed barley; and it is further believed that from this species have been derived Hordeum vulgare, the common six-rowed square-headed barley, and Hordeum hexastichon, the true six-rowed barley. Secale montanum, a wild rye, has been considered to be the prototype of Secale cereale, the cultivated rye; while Avena fatua, a wild oat, or some other species of wild Avena, is believed to be the progenitor of cultivated oats. However, until recently, no one knew anything about the original wild form of wheat and most botanists were inclined to believe that it had become extinct. In 1899, the Count of Solms-Laubach declared that the genealogical record of wheat had been lost forever and that the history of its development could only be written from theoretical considerations. Even whilst the Count was publishing his views, there was a small group of botanists who not only believed that the wild ancestor of wheat would one day be found but that a single head of it was already known. Chief among these men was Körnicke who devoted some forty years to the study of cereals. ${ }^{7}$

6 G. F. Scott Elliott, loc. cit., p. 217.

7 Cf. A. Aaronsohn, Agricultural and Botanical Explorations in Palestine, Bulletin No. 180, Bureau of Plant Industry, United States Department of Agriculture, Washington, 1910, pp. 37-38. 


\section{IV. 'Körnicke's Discovery in a Herbarium}

Körnicke published his great work on cereals in the year 1885. In 1873, when he was preparing the notes for his manuscript, he was looking through the pressed specimens of grasses preserved in the herbarium of the National Museum at Vienna. On examining a sheet of wild barley (Hordeum spontaneum) which Kotschy had gathered in 1855 at Rasheyya, on the northwestern side of Mount Hermon in Palestine, his eye was attracted to the ear of a graminiferous plant which he at once recognized as a species of wild wheat closely resembling the cultivated wheat known as emmer. Curiously enough, he forgot to mention the wild wheat in his book on cereals published twelve years later; and it was not until 1889, at a meeting of the Society of the Lower Rhine and Westphalia, that he reported his discovery to the scientific world. He then named Kotschy's plant Triticum vulgare dicoccoides and declared that it was the prototype of our cultivated wheat. For some years afterwards he repeatedly referred to the wild Triticum and urged botanists who went to the region of Mount Hermon to seek for it. He even endeavored to induce the scientific academies of Vienna and Berlin to organize an expedition to Palestine to find the plant which he felt to be of so much interest; but his efforts were all in vain. ${ }^{8}$

\section{Rediscovery of the Wild Wheat by Aaronsohn}

In 1902, Aaron Aaronsohn, Director of the Jewish Agricultural Experiment Station at Haifa in Palestine, made a visit to Berlin and whilst there Professors Ascherson, Schweinfurth, and Warburg called his attention to the importance, from a theoretical point of view, of finding 8 A. Aaronsohn, loc. cit., p. 37. 
the wild wheat. In 1904, therefore, Aaronsohn visited the foot of Mount Hermon and began his seareh. However, he had but little hope of success, for two other botanists, Post and Bornmüller, had previously botanized in the neighborhood of Rasheyya, the locality on Mount Hermon where Kotschy's original specimen was supposed to have been gathered, and yet in their two Floras of Syria and Palestine they had failed to report finding any species of Triticum. Aaronsohn, therefore, did not long persist in his search and concluded that there had been some mistake in the record of the locality from which Kotschy's wild wheat had come.

In 1905, Aaronsohn was again in Berlin and was urged by the botanists there to renew his search. Stimulated anew, he returned to Palestine, and in June, 1906, took a long trip to Upper Galilee with the intention of going as far as Mount Hermon and of spending as much time as possible in looking for the wild wheat. This time his effort was crowned with success and even sooner than he had anticipated. Whilst on the way to Mount Hermon, he had the good fortune to rediscover the species for which he had sought and thus to bring to light one of the most interesting plants in the world. His own account of the event, which is contained in a Bulletin of the United States Department of Agriculture, will now be quoted:

" On June 18, I was walking with my friend, the agronomist Mr. M. Bermann, in the vineyard of the Jewish Agricultural Colony at Rosh Pinar, at the foot of Jebel Safed, and was trying to demonstrate to him the Eocene origin of the ground. Suddenly I noticed in a crevice of a rock of nummulitic limestone an isolated plant which at first sight looked like a stool of barley, but which on closer inspection proved to be a wheat, the ripe 
spikelets of which could be detached from the brittle rachis by the slightest shake. I could hardly believe that it was really the plant for which I was looking. The development of the head and grains was so perfect - so nearly like the forms produced under cultivation at the present day - that I could scarcely believe that this was their wild prototype, though, to be sure, if it had not been so well developed, primitive man would not have noticed it, or at least would not have appreciated the importance of its cultivation to such an extent as he did.

"I could not at that time remain longer at Rosh Pinar, and so left the next day for the north. On the way from Rosh Pinar to Rasheyya (three days on horseback), I looked for wild wheat, but could not find any. At Rasheyya, too, I spent a great deal of time botanizing in the vineyards in the hope of finding the Triticum there, but also without success. But when I began to extend my search to uncultivated lands, along the edges of roads and in the crevices of rocks, I found a few stools of the wild Triticum. Later I came across it in great abundance, and the most astonishing thing about it was the large number of forms it displayed. The sample specimen of Rosh Pinar, however, was the finest one. This plant had made a very vigorous growth and bore heads of which the stiff, rugose awns (beards) were nearly or quite 6 inches long. At the foot of Mount Hermon the stems were longer but fewer. Instead of being 2 feet high, as at Rosh Pinar, this wild wheat at Rasheyya was more than 40 inches high.

"I ascended Mount Hermon and went around to the other side. I intend at some future time to describe this trip, as its botanical and geological results may interest the scientific world; but here I shall speak only of the Triticum. In descending from the summit of Mount Hermon 


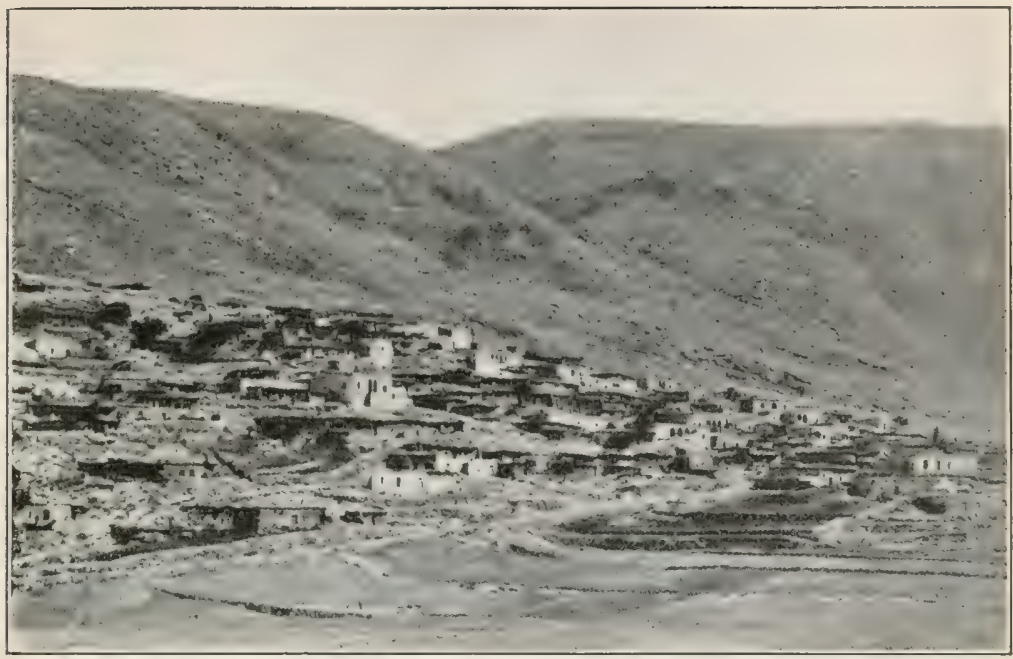

Fig. 44. Tiew of Mejdel esh Schems, on the slopes of Mount Hermon, where Wild Wheat was found. From A. Aaronsohn's Aricultural and Botanical Explorations in Palestine. Courtesy of the United States Department of Agriculture. 


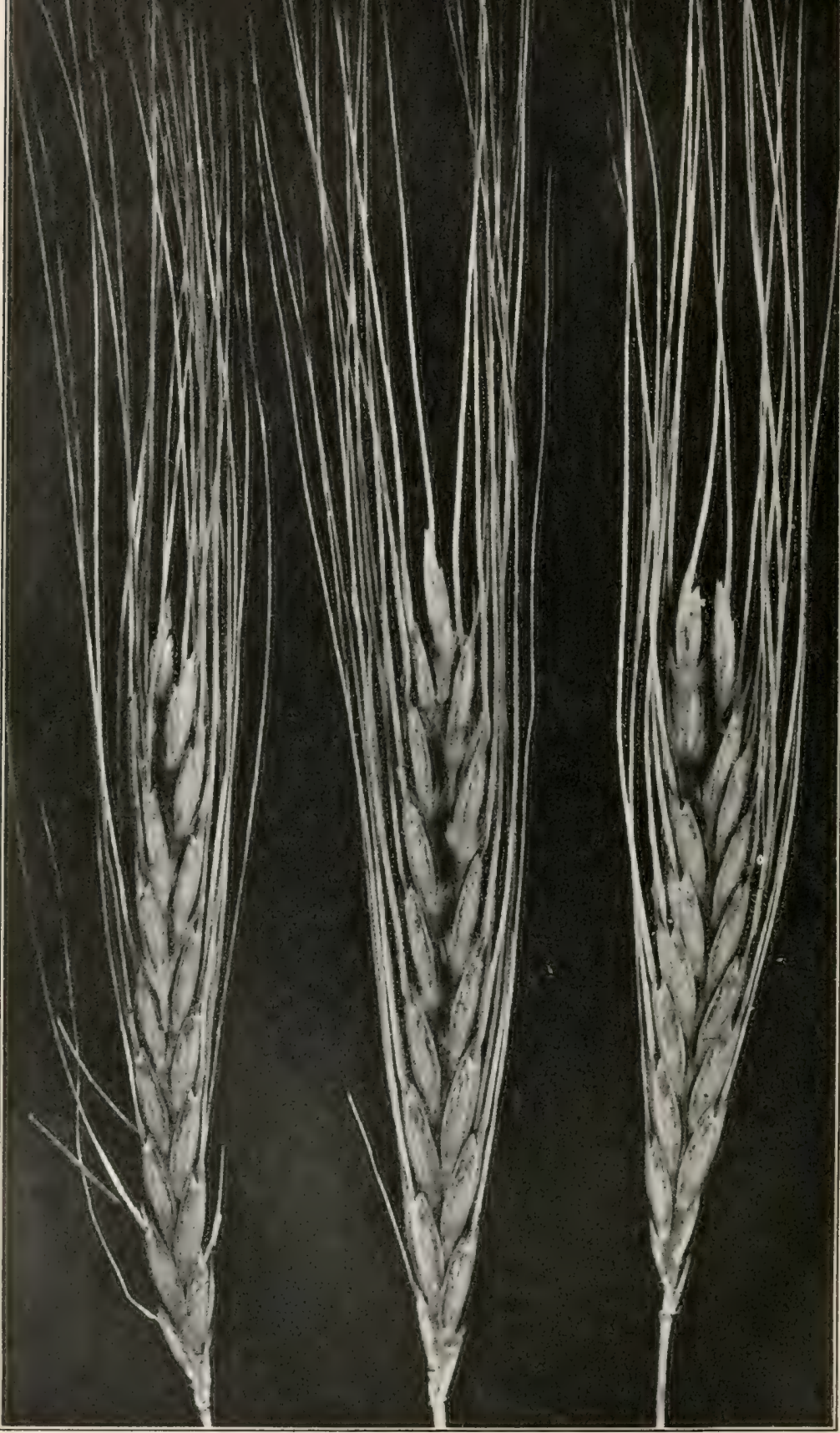

Fig. 45. Heads of an ordinary form of the Wild Wheat of Palestine as grown at Bard, California. Natural size. From O. F. Cook's Wild Wheat of Palestine. Courtesy of the United States Department of Agriculture. 
$(9,498$ feet in altitude) towards Arny, a little village on its eastern slope, I found innumerable forms of this wild Triticum growing in abundance at an altitude of 5,250 feet and less. In some cases the whole ear was black; in others only the glumes or part of the glumes; in still others the awns alone were black. Sometimes the glumes were completely glabrous, sometimes very hirsute; in some the form of the glume resembled that of Triticum durum (durum wheat), in others the development of the secondary nerve was similar to that of $T$. monococcum (einkorn). I had discovered so many forms that no attempt at determination could be made. Among these was even $T$. monococcum aegilipoides, a form I had not at all expected to find. I could therefore only gather specimens, noting their habitat, associations, etc.

"As soon as I got home I wrote the good news to my friends in Berlin. I short notice of the results of this trip and an article by Professor Schweinfurth on the importance of this discovery and on the possibilities which it opened up were published.

" My trip in 1906 merely established the native habitat of Triticum dicoccum dicoccoides. It was still necessary to find out the extent of the distribution, its habit of growth, etc., and I made another trip for this purpose in $1907 . .$. On this trip I was able to show conclusively that Triticum dicoccum dicoccoides is indigenons to the regions of Mount Hermon and the northern part of the Trans-Jordan. The idea that it is a plant escaped from cultivation can not be entertained for a moment. In the first place Triticum dicoccum. (emmer) is not cultivated anywhere in Syria or Palestine. I have not been able to discover any hybrid or mongrel between this wild wheat and the cultirated forms. Second - and this is the important point - our Triticum dicoccum dicoccoides rarely 
appears on soils which have been cultivated for any purpose. It grows only upon the slopes of the most arid and rocky hills and in places exposed to the hottest rays of the oriental sun." (Figure 44.)

Aaronsohn's observations have been confirmed by O. F. Cook of the United States Department of Agriculture, who visited the Holy Land in 1910, found the wild wheat, and carried out an independent investigation upon its characteristics. Cook reports in his well illustrated Bulletin that the wild Triticum is widely distributed on the slopes of the Anti-Lebanon range of mountains in northern Palestine and Syria, and that it behaves in every way as a truly indigenous plant; and he further points out that it is especially abundant on limestone formations where it often appears to be the dominant species. His illustrations show the wild wheat in tufts growing on the arid slopes of hills among stones and bowlders much in the same manner as its distant relatives the Couch-grass or False Wheat (Agropyron repens) and the Slender Wheat-grass (A. tenerum) now grow from the cracks and crevices of the glaciated rocky hummocks which make up so much of the land surface at Kenora and other places on the Lake of the Woods.

The scientific name of the wild wheat used by Aaronsohn is Triticum dicoccum dicoccoides and was chosen because the name of the cultivated wheat to which in Aaronsohn's opinion the wild wheat is most closely related (Emmer), is Triticum dicoccum. The triple name Triticum dicoccum dicoccoides, however, is cumbersome and tautological, and it makes the wild wheat a variety of a cultivated wheat. Moreover, Cook has doubts based on morphological grounds as to the propriety of associating the wild wheat so closely with Emmer. Cook has therefore suggested that the name Triticum dicoccum dicoccoides should 


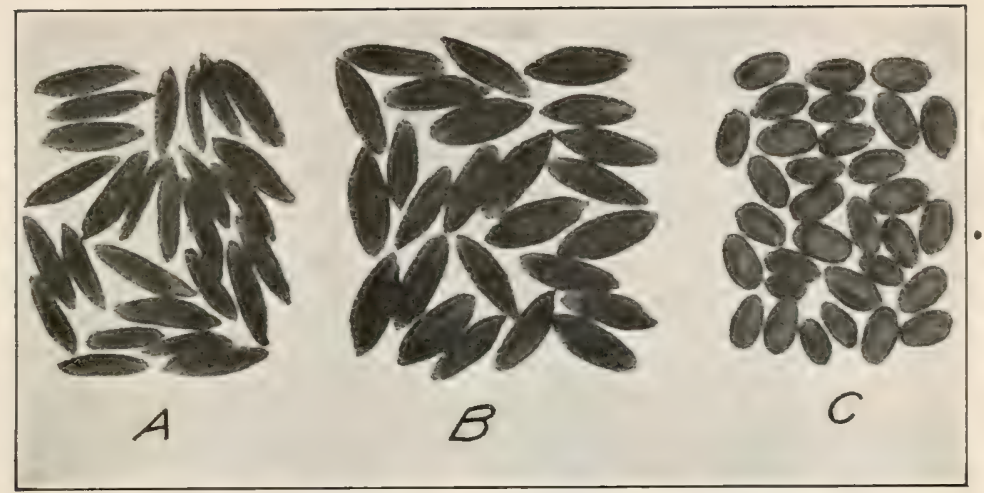

Fig. 46. Wheat Kernels. A, Wild Wheat showing usual size; B. large-seeded variation of Wild Wheat; C, Sonora wheat commonly grown in the same locality at Bard, California. All natural size. The weight of the individual kernels in A. B. C averaged respectively, 0.032 gram, 0.071 gram, and 0.038 gram. From O. F. Cook's Wild theat of Palestine. Courtesy of the United States Department of Agriculture. 


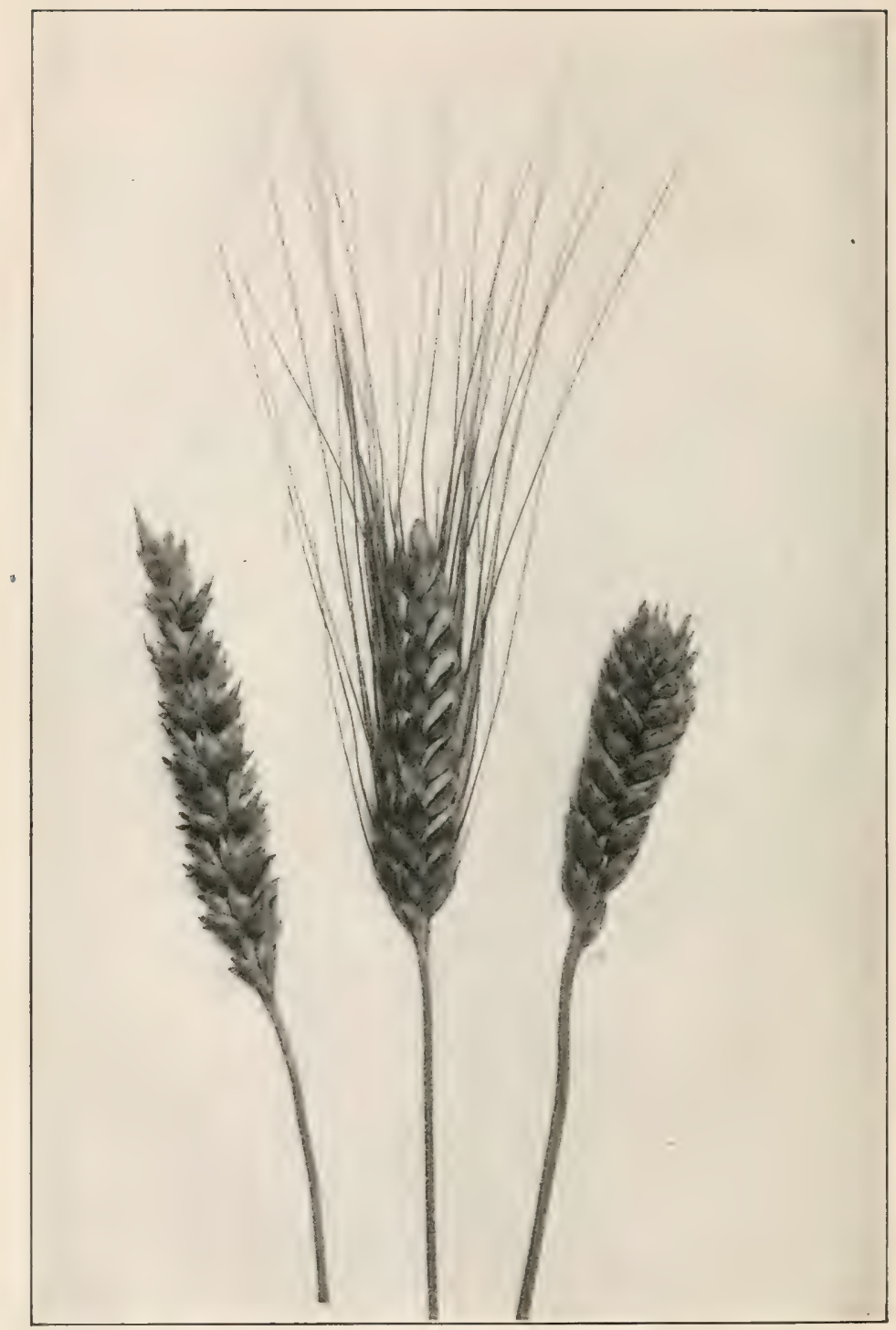

Fin. 47. Classes of Wheat. From left to right: Wheat (Triticum vulgare-Narquis); Durum wheat (Triticum durum-Kiulanka); ('lub wheat (Triticum compactum). Courtesy of Professor John Bracken. 
be discarded and that it should be replaced by Triticum hermonis. This proposed change in nomenclature not only gives to wild wheat the status of an independent species which is its just due, but also serves to commemorate the spot - Mount Hermon - where the first ear was collected. In future, therefore, we shall refer to the wild wheat as Triticum hermonis.

Specimens of Triticum hermonis were brought from Palestine to the United States by Aaronsohn, with the result that at various experimental stations in that country plots of ground are now sown annually with the new cereal. The wild wheat has also found its way to western Canada and has been grown by Professor Harrison at the Agricultural College at Winnipeg and by Professor W. P. Thompson on the campus of the University of Saskatchewan at Saskatoon. I visited Professor Thompson in the summer of 1918 in order to become acquainted with the nature of his cereal investigations and, of course, was shown his little plot of Triticum hermonis. With what interest and delight did he and I examine the newcomer from Palestine, noting its grass-like habit, its relatively short straw, and its bending long-bearded heads, with their primitive and admirable arrangements for scattering the grains; and with what wonder did we reflect upon the possibility that there, at last, before our own eyes, was the very species from which had sprung all the Marquis and Red Fife which, all over the West, even then, was ripening unto harrest. Evidently we were in the presence of a virile vegetable, not dependent for its propagation, as are our cultivated wheats, upon the pampering attentions of mankind, but well fitted by its structure and functions to maintain itself in its native habitat from generation to generation in open competition with the rest of the plant world. 


\section{The Botanical Classification of Wheats}

In order to appreciate why it is that the wild wheat of Palestine has been considered to be the prototype of our cultivated wheats, it is necessary to understand how cultivated wheats have been classified. Eight distinct kinds of wheat have been recognized as follows:

1. Einkorn.

2. Polish Wheat.

3. Emmer.

4. Spelt.
5. Wheat.

6. Club Wheat.

7. Poulard Wheat.

8. Hard or Durum Wheat.

In the great central spring-wheat region of North America, No. 5 or wheat is by far the most important kind, for it includes Red Fife, Marquis, Preston, and Bluestem. No. 8 or durum wheat is also grown in the dryer localities; but few farmers in the West are acquainted with either einkorn, Polish wheat, emmer, spelt, club wheat, or Poulard wheat. The following classification is based upon the studies of Körnicke and Hackel:

\section{Triticum}

Section Eutriticum

I. Triticum monococcum ....................einkorn.

II. Triticum polonicum ...................Polish wheat. III. Triticum sativum ........... a collective species.

1. Triticum dicoccum ....................emmer.

2. Triticum spelta .......................spelt.

3. Triticum tenax .............common wheats.

a. Triticum vulgare (Triticum cestivum)... wheat.

b. Triticum compactum ...............club wheat.

c. Triticum turgidum ............. Poulard wheat.

d. Triticum durum ..............durum wheat.

We thus see that in the section Eutriticum of the genus Triticum there are three species: Triticum monococcum, 
T. polonicum, and T. sativum. Triticum sativum is a collective species and contains three small species: $T$. dicoccum, T. spelta, and T. tenax. Triticum tenax is. in turn subdivided into subspecies: T. vulgare, T. compactum, T. turgidum, and T. durum.

This classification is essentially artificial and the distinctions between the groups are not always clear. Thus Körnicke found it almost impossible to distinguish between some forms of Triticum durum (durum wheat) and Triticum dicoccum (emmer).

Triticum monococcum holds a place distinct from the other kinds of wheat because when crossed with them it does not produce fertile hybrids. All the other kinds of wheat can be crossed without difficulty. Moreover, a wild prototype of Triticum monococcum has been known for a long time and Aaronsohn found a wild form of T. monococcum in Palestine, which is only very slightly different from cultivated einkorn. All the species of cultivated wheats except einkorn pass so gradually into one another that it seems reasonable to suppose that they really belong to one species and have had a common origin.

Aaronsohn definitely regards Triticum hermonis which he found in Palestine as the wild prototype or ancestral species of all our cultivated wheats except Triticum monococcum, the einkorn. In the following paragraphs the argument which he adduces in support of his view, will be quoted verbatim.

\section{The Brittle Rachis of the Primitive Cereats}

"What," says Aaronsohn, "can we suppose the prototype of wheat to have been, and by what characters can it be recognized? A fragile rachis was undoubtedly one of the characters of this wild prototype. ${ }^{9}$ All who have

9 The rachis of the head of wheat is the main axial rod or stalk 
studied the question agree as to this. All agronomists and all botanists regard a rigid rachis as an acquired characteristic, developed by man under eultivation and having a tendency to destroy the plant's natural capacity for dissemination.

"All of the genera and species related to wheat, as Aegilops, Agropyron, etc., have the fragile rachis, a necessity in order that the grain be assured a wide dissemination. It is also needful that the grain remain fixed in its glumes as a general protection against premature germination, decay and destruction by enemies. But this characteristic, so useful to the plant itself, was a drawback to its use by man. Wheat with a brittle rachis requires to be harvested before complete maturity and is difficult to handle. Moreover, grains that are held too closely in the glumes can not be thrashed with flails, but a special system of mills must be used. In Egyptian tombs 6,000 years old have been found heaps of emmer hulls, a careful inspection of which clearly indicates that they were thrashed by such mills, so that their use must date from the most ancient times.

"Wild wheat, the same as wild oats and wild barley, must have been provided with the means for ready dissemination. Man, however, naturally wished to develop forms which are not so difficult for him to handle, and along this line he has succeeded in obtaining a rigid rachis which bears the spikelets. Hordeum jubatum, the Wild Barley, Squirrel-tail Grass or Skunk-tail Grass of the prairies, has such a brittle rachis. As soon as the head is ripe, the rachis breaks up into some twenty or more joints to each one of which are attached three little spikelets, the center one containing a single grain. Every one knows what a successful weed Wild Barley is. It is its brittle rachis, however, which makes its dissemination possible. Were its rachis to become rigid, as in our eultivated wheats and barleys, the scattering of its grains would be prevented and no doubt it would quickly cease to be noxious. A. H. R. B. 


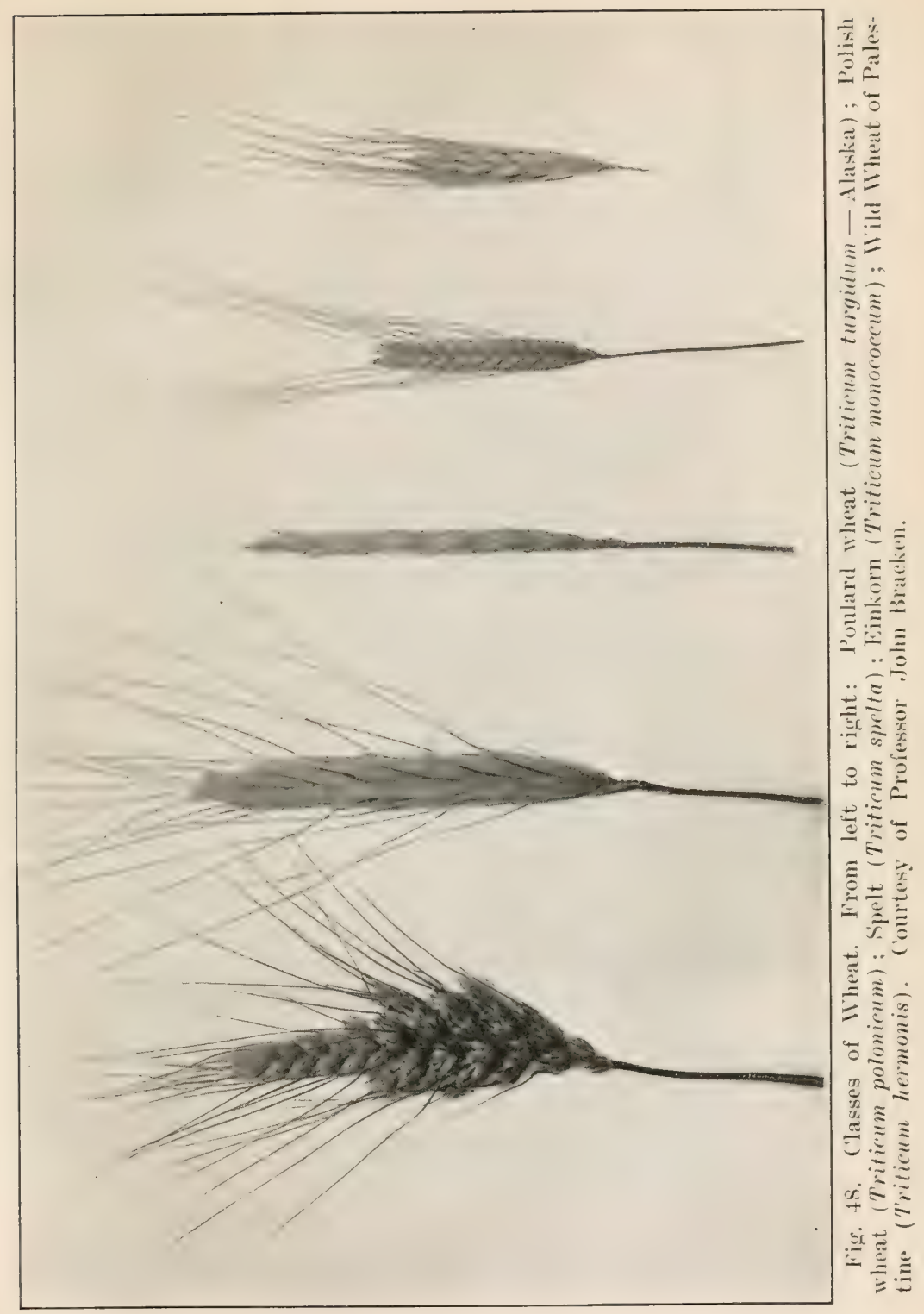




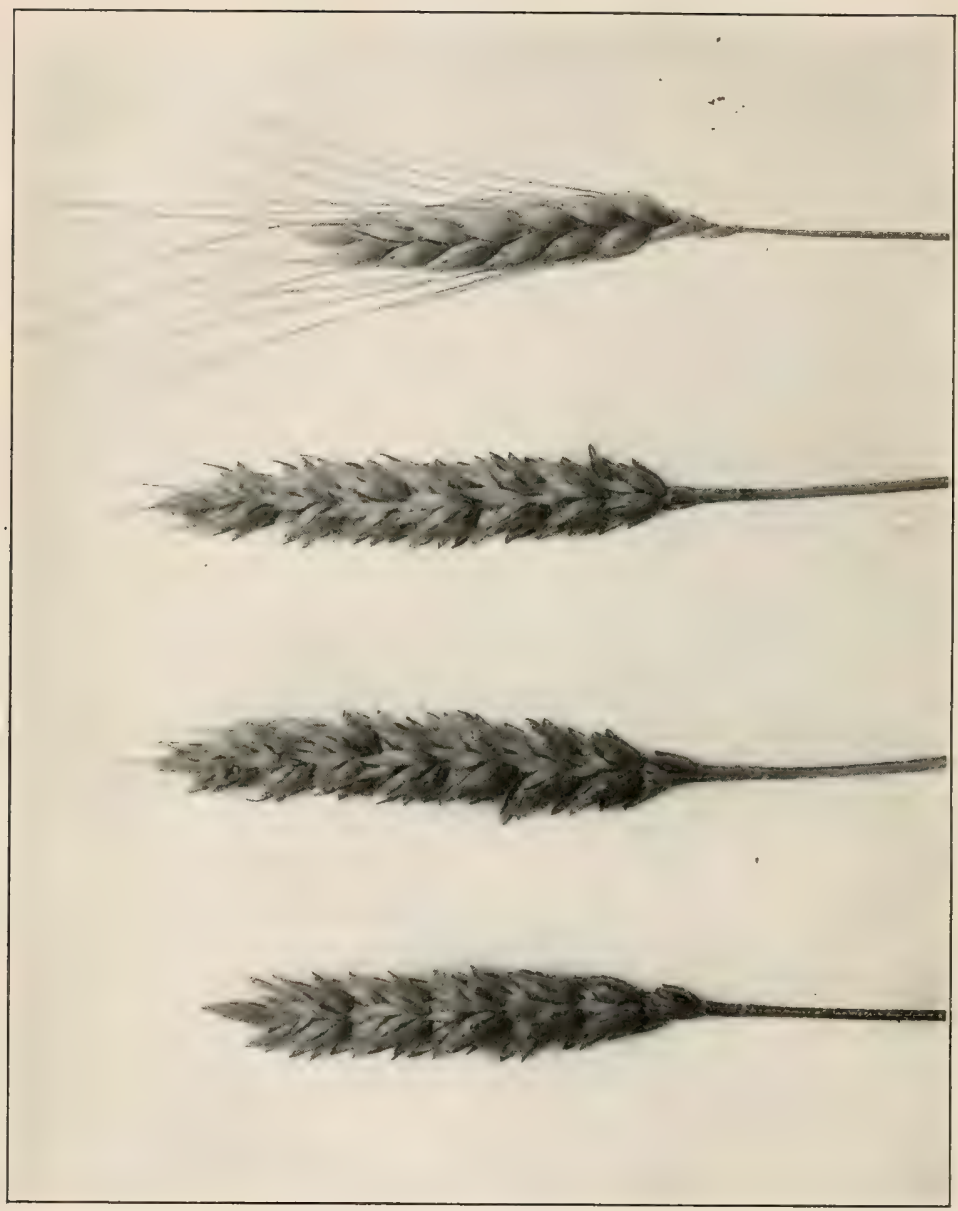

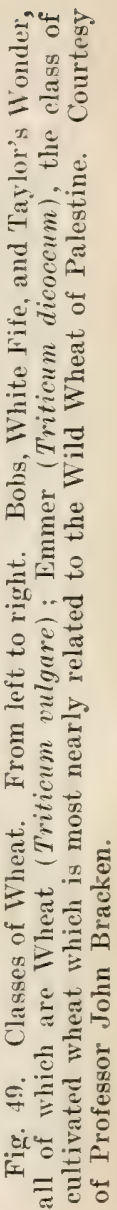


in barley as well as in wheat. An important difference between the cultivated two-rowed barley (Hordeum distichon) and the wild barley (Hordeum spontaneum) is the fragile rachis of the latter. But more than this has been accomplished with wheat. Forms have been developed in which the grains are very readily removed from the glumes. In barley and oats this has not been done to the same extent. We have, it is true, naked varieties of these two cereals, but these varieties have not been extensively cultivated, doubtless on account of their relatively smaller yield, and until a comparatively recent date their cultivation has been confined to the Orient. In wheat, on the contrary, naked grains and a rigid rachis are the general rule, these two characteristics differentiating the cultivated forms from the primitive type and making the former incapable of perpetuating itself without the intervention of man.

\section{Cultivated Wheats with a Brittle Rachis}

"Among the known cultivated wheats there are three that still retain the brittle rachis: Einkorn (Triticum monococcum), emmer (Triticum dicoccum) and spelt (Triticum spelta).

"It is known that the cultivation as grain crops of einkorn, emmer, and spelt is steadily decreasing. An attempt has been made in comparatively recent times both in this country and in Russia to cultivate einkorn and emmer as forage plants. It is interesting to note that, except for these attempts, these wheats are cultivated today only by the Basques, ${ }^{10}$ the primitive Swabians, ${ }^{11}$ the

10 The Basques live on both sides of the Pyrenees in Spain and France. A. H. R. B.

11. The Swabians live in the old Kingdom of Wiirttemberg, in Hesse, and in the western part of Bavaria. A. H. R. B. 
Serbes and that peculiar people the Bactrians of Persia. "The cultivated wheats with a rigid rachis are therefore derived from the wheats with a brittle rachis. But of the three species which have this common character, which one shall we select as the prototype and why make this selection to the exclusion of others?

\section{Einkorn and Its Prototype Distinct from other Wheats}

"More than fifty years ago Balansa discovered Triticum monococcum cegilipoides in the wild state. This differs from the cultivated Triticum monococcum (Einkorn) only in minute characters and is without doubt its prototype. Balansa believed that he had found the progenitor of the cultivated wheats, an opinion that Haussknecht also accepted at the time. But experiments in crossing undertaken more than fifty years ago by Vilmorin led him to assert that whereas all the other species of wheats crossed with each other perfectly and gave mongrels, or fertile offspring, he had never succeeded in crossing Triticum monococcum with any other wheat. Later, Beyerinck succeeded in producing the cross, but the products were strict hybrids; that is, they were all sterile. líore recently still, Professor von Tschermak, who took up Vilmorin's experiments, met with the same failure. He has succeeded in crossing Triticum monococcum with Triticum ovatum which, as we have seen, may in turn be crossed with Triticum astivum; but neither he nor any one else has succeeded in crossing Triticum monococcum with any other wheat.

"Let us note, however, that in the case of Triticum polonicum there was difficulty in crossing, because of the peculiar form of its glumes, until a particular operative technique har been worked out. In view of this we may 
question whether the failure with einkorn was not also caused by a faulty technique. We may remark in this connection that, as Doctor Trabut observed, ${ }^{12}$ no one has ever succeeded in crossing the two varieties of Anagallis arvensis, corrutea and phonicia, although the only difference between the two is that the former has blue and the latter pink flowers. But we can not on this account class them as distinct species.

"In so far, therefore, as the lack of sexual affinity between two related forms justifies us in recognizing in them two distinct species, Triticum monococcum must be considered as standing alone, and it cannot be regarded as the progenitor of the cultivated wheats.

"From the historical point of view, also, we may reject einkorn as the progenitor of wheat. Its cultivation can not have gone back to very ancient times, since the cultivated form differs so little from the wild one. The only evidence that we possess of any antiquity is that Schliemann discorered it in his celebrated excavations of ancient Troy, showing that it was cultivated there. ${ }^{13}$ But the other cultivated wheats are traced back for thousands of years before this.

"Spelt and emmer, then, are the only two forms remaining to be considered, but we have no ancient remains of the cultivation of spelt, nor is there any mention of it in literature until toward the beginning of the Christian era.

12 Bulletin de la Société Botanique de France, Vol. 68, p. 182.

13 This evidence for the antiquity of einkorn has turned out to be worthless, for Aaronsohn now reports that the supposed einkorn found at Troy was afterwards identified by Wittmach as barley on the basis of a microscopical examination. Tide O. F. Cook, Wild Wheat in Palestine, Bulletin No. 274, U. S. Department of Agriculture, 1913, p. 26. A. H. R. B. 


\section{Emmer the Only Possible Prototype of True Wheat}

"The species of grain of the cultivation of which we have the oldest records is emmer. It is true that durum wheat has been found in Egypt in some tombs of the first dynasty - that is four thousand years before the Christian era - but emmer is found both in far greater abundance and in all of the tombs. It is not at the present time cultivated anywhere in Egypt, durum wheat having since historic times taken its place.

"Emmer has been found in the lake dwellings of Wangen and Robenhausen, which date back to the end of the neolithic epoch, a little before the bronze age. This, therefore, is the only species which has been cultivated from the very beginning of civilization, and we are justified in asserting it to be the progenitor of our cultivated wheats. This explains why it was so desirable to find the wild form."

Every one will admit that the wild wheat of Palestine possesses all the characters that specialists expected to find in the primitive ancestor or prototype of our cultivated common wheats; but such characters, as Cook has pointed out, might be expected to occur in any wild relative of these wheats. These characters, therefore, do not afford absolute proof of the parental position of Triticum hermonis in respect to our cultivated wheats. It is possible that other wild wheats still remain to be discovered in Palestine or in neighboring countries which are much less wellknown botanically, and that one such species may be found to stand still nearer to our cultivated wheats than does Triticum hermonis. Cook ${ }^{14}$ has suggested that the real prototype may be a wild species growing somewhere in Arabia or elsewhere in western Asia which has heads with 14 O. F. Cook, loc. cit., p. 26. 


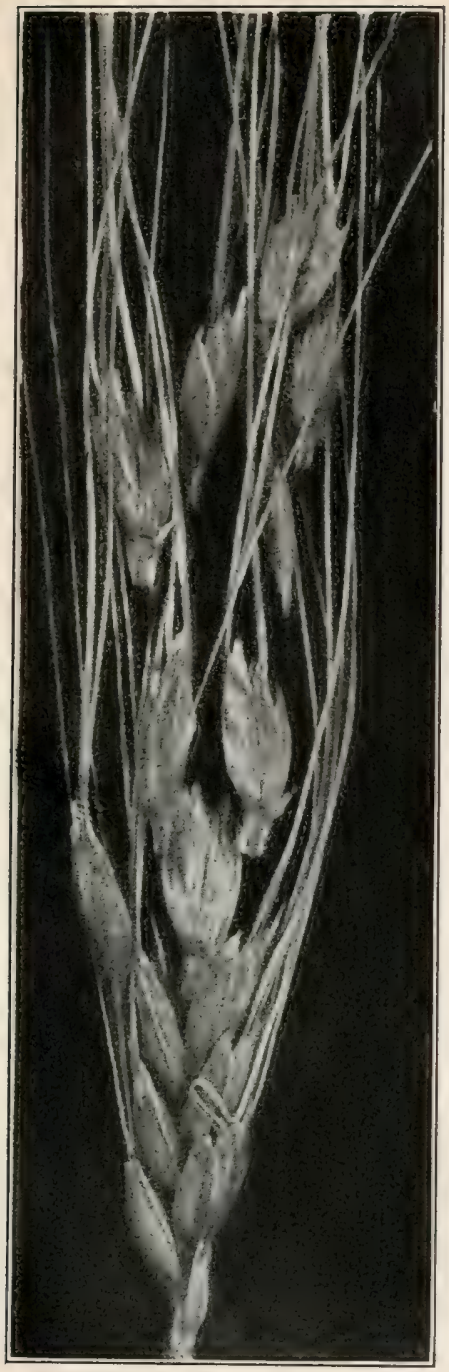

Fig. 50. Head of a largeseeded variation of the Wild Wheat (Triticum hermonis) with the spikelets falling apart. From O. F. Cook's Wild Wheat of Palestine. Courtesy of the United States Department of Agriculture. 

a non-brittle rachis and which is therefore so like our cultivated wheats that it differs from them in scarcely anything except that it grows wild and maintains itself from generation to generation without the aid of man. However, it may be urged against the likelihood of finding such a wild wheat that our cultivated wheats, although grown on such diverse soils, in such varied parts of the world, and so extensively, have nowhere succeeded in escaping from cultivation and maintaining themselves in the wild state. It is also possible that the primitive wild ancestor of our cultivated wheats has become extinct leaving behind only close relatives such as Triticum hermonis. However, the writer is inclined, tentatively at least, to accept Aaronsohn's conclusion. At any rate there can be no doubt that the wild wheat of Palestine has a better claim to be considered the ancestor of our cultivated wheats than any other known species. Even if, with the progress of botanical knowledge, Triticum hermonis should prove not to be the prototype we are seeking, this species will doubtless be found to be extremely similar to that prototype. It must therefore continue to be one of the most interesting of all plants.

\section{Cross-Fertilization}

The wild wheat of Palestine differs from our common cultivated wheats in that it is well adapted for cross-pollination. Some of the flowers, says Cook, ${ }^{15}$ have their anthers pushed out beyond the glumes before the shedding of the pollen, and, conversely, in some flowers the glumes spread apart so that the pollen is admitted before the anther's mature. The pushing outwards of the anthers beyond the tips of the glumes allows the pollen to be scat15 O. F. Cook, loc. cit., p. 51. 
tered by the wind, and the spreading of the glumes permits wind-blown pollen to fall upon the stigmas. The two glumes of a flower, when opening occurs, separate at an angle of from $30^{\circ}$ to $40^{\circ}$ so as to form a broad tube or funnel with the expanded stigmas at the bottom. Although well protected on all sides, the stigmas can be seen in the open flower by looking in from above. ${ }^{16}$

Cook, when studying pollination in the wild wheat, found indications of sexual dimorphism, ${ }^{17}$ i. e., that there are two forms of flowers regarded sexually. In some plants which he examined, the flowers were proterogynous, the stigmas being exposed before the adjacent anthers had matured, whilst in other plants the flowers appeared to be proterandrous, the anther's being exserted at a time when the stigmas were still only partly developed. Seed was also found to be produced in some heads that had not emerged from their sheaths, from which we may conclude that some forms of Triticum hermonis are capable of self-fertilizing their own flowers. Cook's observations go to show that in the wild wheat of Palestine the usual mode of pollination is cross-pollination.

The Grass Family or Graminex, as a group, possesses flowers with floral mechanisms adapted to secure crosspollination; and, for grasses in general, we must look upon this mode of pollination as primitive and ancestral. The wild wheat of Palestine, which is a wild grass, therefore resembles most other grass species in having crosspollinated flowers. In our cultivated wheats, on the other hand, self-pollination is the rule, although cross-pollination may and does take place occasionally. ${ }^{18}$ We may

16 Ibid., p. 15.

17 Ibid.

18 Tide Chapter IV, Section V, on Red Bobs the Product of a Natural Cross. 
therefore regard our cultivated wheats as sexually degenerate. Since the wild wheat of Palestine has cross-fertilized flowers, there seems good reason for supposing that in our cultirated wheats self-pollination came to replace cross-pollination under conditions of domestication.

An attempt will now be made to summarize some of the chief observations which have been made upon the opening of the flowers and mode of pollination of our common wheats.

The results of careful observation by botanists and cerealists upon the pollination of cultirated wheats seem to show: (1) that in cooler northern regions. such as northern Europe, the northern part of the United States, and Canada, self-pollination is the rule but that crosspollination may and does take place occasionally, (2) that in warmer regions cross-pollination is more frequent, and (3) that in hot dry localities, such as the canal colonies of the Punjab where the crop can only be grown by means of irrigation, cross-pollination is quite common. ${ }^{19}$

Delphino observed that at flowering time the glumes direrge rapidly and suddenly. At the same time, the anthers project laterally, open, and empty about one-third of their pollen on the stigmas of the same flower, while the rest of the pollen is scattered in the air. This happens in about one minute and, after a quarter of an hour, the glumes close again. Delphino made experiments which prove that automatic self-pollination results in the setting of good fruits. ${ }^{20}$

Delphino and Körnicke found that a single wheat flower

19 A. Howard, Gabrielle L. C. Howard, and Rahman Abdur, The Economic Significance of Natural Cross-fertilization in India, Memoirs of the Department of Agriculture in India, botanical series, Vol. III, October, 1906.

20 Tide P. Knuth, Handbook of Flower Pollination, translated by J. R. A. Davis, Oxford, Vol. III, 1909, p. 529. 
remains open for only about a quarter of an hour but that the flowering period for a whole head has a duration of four days, so that only a small number of flowers are found open at any one time. ${ }^{21}$ It has been noticed by many. observers that, in a single head, the first flowers to open are the median ones and that flowering proceeds upwards and downwards in the head, the last flowers to open being those in the spikelets at the head's extreme ends.

Kirchner's observations support those of Delphino, and are as follows: The flowers which are homogamous, gradually open so widely that the tips of the glumes are about $4 \mathrm{~mm}(1 / 6$ inch $)$ apart. As a flower opens, the anthers of the stamens dehisce apically and about one-third of the pollen falls into the flower. After this the anthers come to project outside the glumes so that they scatter their pollen into the air. Self-pollination therefore takes place regularly but cross-pollination by means of the wind is not excluded. Kirchner also observed that the flowering period for a single head was four days in length. ${ }^{22}$

Godron found that the flowers open in the early morning and that the extent of their opening depends upon weather conditions. His observations were as follows: At $16^{\circ} \mathrm{C}$. $\left(61^{\circ} \mathrm{F}\right.$.) the flowers open at $4.30 \mathrm{~A}$. M. and close again at 6.30 to $7 \mathrm{~A}$. M. If, when the flower opens, the anthers tip over the ends of the glumes quickly, the stigmas of the flowers as a rule are not dusted with pollen. Under less favorable circumstances, the flower opens more slowly and the stigmas do not project until they have been dusted with pollen from the same flower. At a low temperature, $12^{\circ}-13^{\circ} \mathrm{C}$. $\left(54^{\circ}-56^{\circ} \mathrm{F}\right.$. $)$, or after several days' rain, the flowers remain closed and fertilization takes

21 Ibid.

22 Ibid. 
place without the flowers opening (pseudo-cleistogamous fertilization). ${ }^{23}$

Rimpau has also observed the effects of temperature on the opening of wheat flowers. He states that at $12^{\circ}-13^{\circ} \mathrm{C}$. $\left(54^{\circ}-56^{\circ} \mathrm{F}\right.$.) the glumes do open a little but that complete opening does not take place under $16^{\circ} \mathrm{C}$. $\left(61^{\circ} \mathrm{F}\right.$.). He found that the opening of the glumes is not limited entirely to the morning hours but may take place at any hour of the day or even in the evening. The length of time during which the flowers are open depends on the temperature and the dryness of the air: at $23^{\circ} \mathrm{C} .\left(73^{\circ} \mathrm{F}\right.$.) the flowers closed again in 15-20 minutes, but at lower temperatures closing took a much longer time. Rimpau observed that the anthers dehisce before they have reached the upper margins of the glumes by elongation, so that automatic self-pollination is regularly effected in every flower. ${ }^{24}$

Rimpau removed the anthers from 85 wheat flowers and yet 50 of them set fruit. He therefore concluded that if self-pollination were not to take place, pollination by crossing would still ensure the production of seed. He found that crossing, as judged by the average number of haulms formed, gave rise to a more vigorous off-spring than self-pollination, the result being seen even in the fourth generation. ${ }^{25}$

The flowers of wheat only open once and for a very short time. The actual opening which results in the divergence of the glumes and the exposure of the sexual organs, is effected by two small scales known as lodicules which lie at the base of the flower between the ovary and the outer glume. As a flower opens, the lodicules become fleshy and

23 Ibid.

24 Ibid.

25 Ibid. 
succulent and more or less spheroidally swollen at the base. By swelling up in this way, they overcome the resistance of the elastic outer glume and move it outwards. After a short time the lodicules shrivel up again into small thin scales thus allowing the outer glume to resume its former position and close the flower again. The action of the lodicules in opening the flowers of grasses was first investigated in 1880 by Haeckel, and his observations were confirmed by Rimpau in 1883 . When a flower opens, the filaments of the three stamens grow very rapidly in length, and it is this rapid growth which causes the anthers to be pushed out of the flower over the ends of the glumes. This observation was first made by Arkenasy and afterwards confirmed by Rimpau. ${ }^{26}$

Kerner states that the most favorable conditions for pollination in most Grasses prevail in the early morning, at an hour when there is still some dew lying in the meadows, when the first rays of sunshine fall obliquely upon the flowers, when the temperature is rising gently, and when a light breeze sets the spikes and pannicles in motion. "Under such conditions as these the phenomena of flowering and pollination are accomplished with astonishing rapidity. In some Grasses an observer may see the glumes relax and spring open, the stamens grow out, the anthers open, and the pollen scattered, all in the space of a few minutes." 27 Wheat is only a glorified grass and although its flowers open early in the morning there are other grasses which, under mid-European conditions, open their flowers just as early or even earlier. The time at which the flowers of wheat open relatively to those of other grass species is indicated by Kerner in

26 P. Knuth, loc. oit., p. 515.

27 Anton Kerner von Marilaun, The Natural History of Plants, translated by F. W. Oliver, London, Vol. II, 1895, pp. 141-142. 
the following statement. "The earliest discharge of pollen (in the Graminex) begins in the height of summer between 4 and 5 A. Mr. and the plants which take part in it thus early are the Meadow-grass (Poa), Koeleria, and Avena elatior. A little later between 5 and 6 o'clock comes the turn of the Quaking-grass (Briza media) and Aira cospitosa, and of Wheat and Barley (Triticum, Hordeum). Between 6 and 7 pollination occurs in Rye and in a great number of different Grasses which grow in meadows, such as Cock's-foot-grass (Dactylis), Andropogon, the Brome-grasses (Brachypodium) and many species of Fescue (Festuca). Between 7 and 8 o'clock the pollen is liberated from Oats of the Trisetum group, from the Fox-tail-grass (11opecurus), Timothy Grass (Phleum) and the Sweet Vernal Grass (Anthoxanthum). An interval now intervenes, at least among the indigenous Grasses. Of exotic species which are cultivated in gardens the following discharge their pollen in the course of the forenoon, viz., the Millets (Panicum milliaceum and Sorghum) between 8 and 9 o'clock; Setaria Italica and the Brazilian Pampas-grass (Gynerium argenteum) between 9 and 10 o'clock. Toward noon indigenous Grasses come again into play. About 11 o'clock pollination takes place in most species of the Bent-grass genus (Agrostis) and between 12 and 1 in Melic-grass (Melica), Molinia, Mat-grass (Nardus), Elymus, Sclerochloa, and several species of Calamogrostis. In the course of the afternoon the process takes place in a few isolated species as, for instance, in some Brome-grasses at 2 o'clock, in a few species of Oat (Avena) at 3 , in Agropyrum at 4 , and in Aira flexuosa between 5 and 6 . It is worthy of note that Soft-grass (Holcus), under favorable atmospheric conditions, opens its glumes, pushes forth its anthers, and liberates pollen twice a day, once in the 
morning about 6 o'clock and a second time in the evenning at about 7 - provided always that the temperature of the air is not less than $14^{\circ} \mathrm{C}$. $\left(57^{\circ} \mathrm{F}\right.$. $)$. The entire process lasts in most eases from fifteen to twenty minutes for each flower." 28

\section{Conclusion}

Here the writer must bring to a conclusion his remarks upon Wheat - the cereal which is and has been of such vast importance to the world, which was the chief basis of the ancient civilization of the lands of the Mediterranean, and which is still the main source of food for the civilization of modern Europe, of a large part of Asia, of North and South America, and of Australia. If there had been no wheat upon the earth during the last 25,000 years or if wheat had been present but primitive man had not succeeded in domesticating it, it is certain that the course of man's evolution would have been greatly retarded and that the New World, where these pages have been penned, would wear to-day a very different aspect to that with which we are familiar. That bread-eaters should desire to know more about the origin and history of the cereal which sustains them is most natural. If this curiosity should be satisfied to some extent by what has been gathered together in this book, the author will feel that his labor has been well rewarded.

28 Ibid., p. 142.

THE END 


\section{INDEX}

A

Aaronsohn, A., brought wild wheat to the United States, 291 ; on the origin of wheat, 285; rediscovery of wild wheat by, 286-291; regards Triticum hermonis as the wild prototype of cultivated wheats, 293299.

Abdur, Rahman, on natural crossing of wheats in India, 301.

Admixtures of wheat, 70-71; in North Dakota, 161.

Advance toward the north of the belts of wheat and corn, 187190.

Agassiz, and Marquis wheat, 152; wheats crossed at, 148.

Agrarian movement, the, 141143.

Agriculture, goddess of, 280 283 ; its importance and antiquity, 278-279.

Agropyron repens and $A$. tenerum at Kenora, 290.

Agropyrum, time of pollination of, 305 .

Agrostis, time of pollination of, 305.

Aira caespitosa and A. flexuosa, time of pollination of, 305 .

Albert barley, C. E. Saunders and, 240.

Alberta, durum wheat in, 42; and hulless barley, 240; and Prelude wheat, 184; and the shelling of wheat, 197; and the Survey Board, 97; and the agrarian movement, 141; and the yield of Marquis wheat, 190 ; export of grain from, 51 ; flour mills of, 134; introduction of Marquis into, 157; Marquis wins prize from, 173; spring and winter wheat in, 35-36; wheat sent through Panama Canal, 52-53; yield of Marquis on C. S. Noble's farm, 191-192.

Alcock, A. W., and the Dominion Grain Research Laboratory, 102-104; and the Panama Canal, 52-53.

Allied governments, negotiate with Board of Grain Supervisors, 129.

Allies, and Canadian flour, 136; flour purchases for, 124; purchase of wheat for, 120 .

Alpha wheat and parentage of Prelude, 186.

Alopecurus, time of pollination of, 305 .

-A moeba histolytica, as cause of the Bloody Flux, 27.

Anagallis, difficulty of erossing, 297.

Andrews Grain Company, and Marquis wheat, 160.

Andropogon, time of pollination of, 305 .

Angus Mackay Farm Seed Company, 159, 160.

Anthoxanthum, time of pollination of, 305 . 
Apples, hardy, for the Northwest, 145 .

Arabia, a wild wheat possibly grows in, 298.

Arctic circle, wheat-growing near, 181-182.

Argentina, wheat crop of, 38, 39, 40 ; lack of wheat surplus, 123.

Aristotle, mentions rust disease, 283.

Arkangelsk, and wheat-growing, 182.

Arkenasy, on elongation of staminal filaments of wheat, 304 .

Arny, A. C., comparison of Minnesota wheats by (Figs. 29, 30, $31), 166,170,171$; on yield of Marquis, 192.

Arny, wild wheat found at, 289. Arthur pea, 240-241.

Ascherson, Professor, and the wild wheat, 286.

Athens and agriculture, 281.

Atlantic Ocean, and Marquis wheat, 158; and the Panama Canal, 53.

Australia, and white wheats, 260 ; export of wheat from, hindered during war, 123; Farrer's wheat-breeding work in, 259-260; wheat eaten in, 306 ; wheat exported in bags from, 52 ; wheat varieties from, 146.

A vena elatior, time of pollination of, 305 .

Awns, of Marquis wheat, 223; of wild wheat, 288 .

\section{B}

Babylonia, wheat of, 279. Bactrians, cultivated einkorn and emmer, 296.
Bailey, C. H., comparison of Minnesota wheat by (Figs. 29, $30,31), 166,170,171$; milling and baking tests, 203; on Marquis in Montana, 166; on Marquis in the Pacific North-west, 165 ; on quality in wheat, 198199.

Baking oven, electric, for experiments, 103.

Baking strength of flour, 199200.

Balansa, discovered wild einkorn, 296.

Baldwin Flour Mills and Marquis wheat, 161 .

Ball, C. R., on percentage of Marquis in the wheat crop, 251.

Ball, C. R. and J. A. Clark, describe Marquis wheat, 171172; experiments with Marquis, 203-204; on geography of Marquis, 164; on increase of Marquis, 168; on ifarquis crops, 160; on Marquis west of the Rocky Mountains, 166; on Preston wheat 149 ; on yield of Marquis, 204.

Baltimore, export of wheat from, $50-51$.

Banks, and grain exchanges, 119; finance crop movements, 130-134; importance of, 133.

Barley, and a distillery, 18; evolution of, 294-295; found at Troy, 297; improvements of, 239-240; in 1813 in Selkirk settlement, 4 ; in 1822 , in census, 16 ; origin of, 285 ; time of pollination of, 305 ; sown in 1816,7 ; wild species in Manitoba, dissemination of, 294; wild species in Palestine, 286. 
Barnes and Company, O. J., and Marquis wheat, 161.

Basques, cultivate einkorn and emmer, 295.

Bawlf, W. R., on Dominion control of grain trade, 129.

Bayah wheat, in Australia, 259.

Bearded Fife wheat, 149.

Beef, price of, in 1826, 19 .

Belgian Relief Commisson, purchase of wheat for, 124 .

Belgium, and Marquis wheat, 228.

Bell, C. N., on Passenger pigeons in Manitoba, 4-5; on weeds introduced with seedwheat in $1820,13$.

Berg, Jacob, and origin of Minnesota No. 23 corn, 188.

Berlin, and the wild wheat, 286 , 287, 289.

Bermann, M., and the wild wheat, 287.

Beyerinck, wheat hybrids of, 296.

Biffin, R. H., on rust-resisting wheats in England, 179.

Birchard, F. J., and the Dominion Grain Research Laboratory, 102-104; and the Panama Canal, 52-53.

Birds, injury of erops by, 4 .

Birtle, and Marquis wheat, 174 .

Black Sea, and Red Fife wheat, 210.

Black, W. J., on corn grown in Manitoba, 189.

Bloody Flux disease, 26-27.

Bluestem wheat, and Marquis in U. S. A., 164; and natural crossing with, 266-267; and Quality wheat, 236; and rust disease, 180; and shelling, 187 ; and time of ripening, 175; classification of, 292 ; improvement of, by Haynes, 224
225; in Canada, 180; in Minnesota, 163; mixed in North Dakota, 162; percentage in crop, 167-169; replacement by Marquis in Minnesota, 246248 ; yield of, in the United States, 193-196.

Board of Grain Commissioners, and Board of Grain Supervisors, 127; and Dominion Grain Research Laboratory, 102; and rules of Winnipeg Survey Board, 97 ; and weighing grain, 100; appoints Grain Standards Board, 104; when created, 68. Board of Grain Supervisors, constitution of, 127-128; functions of, 127; prices fixed by, 92 ; regulates export of wheat, 129.

Boats, number of, in Selkirk settlement in $1849,27$.

Bobs wheat, origin of, 259-260; sold by Seager Wheeler, 270; studied by John Bracken, 270271.

Bolley, H. L., estimate of Marquis wheat grown in North Dakota, 161; inspects Canadian fields of Marquis, 159; on the shelling of Bluestem wheat, 197.

Bornmüller, failed to find wild wheat, 287.

Boss, Andrew, discovers earlyripening corn varieties, 187 188; on Marquis wheat, 162; on Northwestern Dent corn, 190.

Boston, export of wheat from, $50-51$.

Box-cars, for transporting wheat, 57-59; emptying of, at terminal elevators, 52; how contents are known, 83; numbers upon, 
82 ; overfilling of, $86-87$; plugging of, 86 ; samples taken from, 79-81.

Brachypodium, time of pollination of, 305 .

Bracken, John, his red-seeded selections from Bobs wheat, 270 271 ; illustrations supplied by, $157 ; 200,291,294,295$; on the rust disease, 178-179; on wheat growing, 41.

Bran layer, color of, 261-262.

Brandon, Experimental Farm at, 26 ; flour mills at, 135; Marquis wheat introduced at, 157; Marquis tests at, 175; wheatcrossing at, 148; wheat crosses made at, 152; yield of Marquis at, 191, 196.

Bread, and civilization, 230 ; and Quality wheat, 234; eaters of, and the history of wheat, 306 ; from Marquis wheat, 158; making of, and wheat color, 262.

British Columbia, flour mills of, 134; Marquis wheat in, 157; wheats crossed in, 148.

British Government, and the Wheat Export Company, 120.

British Isles, and Marquis wheat, 228.

British market, and wheat color, 260-261.

British miller, 200.

British public, assists Red River settlement, 28.

Briza media, time of pollination of, 305 .

Brown-Duvel moisture-tester, description of, 89 .

Bryce, G., on history of Selkirk settlers, 2, 13, 32 .

Buenos Ayres, and the Winnipeg Grain Exchange, 105.
Buffalo, as a source of food, 8, $11,14,18,23$.

Buffalo, seed Marquis made available at, 164-165; wheat traffic through, 49-50.

Bulk wheat, shipment through Panama Canal, 52, 103.

Bull, C. P., a corn selection made by, 188.

Bunyip wheat, in Australia, 259. Burbank, Luther, and C. E. Saunders, 228-233; appreciation of, as a plant-breeder, 228-232; his potato and plums, 232; his Quality wheat, 233-237.

Buying and selling of wheat, at the Grain Exchange, 111-118; war competition for, 124 .

\section{C}

Calamogrostis, time of pollination of, 305 .

Calgary, cars inspected at, 91 ; flour mill at, 135; government elevator at, 64, 102; inspection of grain at, 78 .

California, and Burbank's new wheats, 233-237; iruit-growing industry of, 231-232; yield of Marquis wheat in, 192.

Camas Prairie, Marquis wheat at, 165.

Campbell, Allan, on ripening of corn in Manitoba, 190.

Canada, debt owed by, to inventors, 138; increased wealth brought to, by Marquis, 252257 ; the granary of the British Empire, 34.

Canada Grain Act, chief features of, 68 ; weighing provisions of, 99. 
Canadian Agriculturist, The, and the origin of Red Fife wheat, 207.

Canadian Council of Agriculture, 127.

Canadian Northern Railway, and the wheat funnel, 49 ; terminal elevator of, 102.

Canadian Pacific Railway, and the wheat funnel, 49 ; building of the, 33-34; encouraged wheat-growing, 217-218; leased in elevator, 142; prizes offered by, 172 ; record haulage of cars on, 66 ; terminal elevator of, 102; Transcona elevator of, 64 .

Canadian Seed Growers Association, 262, 274, 275.

Canadians, and Marquis wheat, 144.

Canoes, number of, in 1849, 27.

Carleton, M. A., estimate of loss due to rust, 180.

Cars of grain, number inspected, 91.

Carts, number of, in 1849, 27.

Cary, Captain, his experimental farm, 25.

Cattle, and corn, 189-190; number of, in 1849, 27.

Cedar wheat, in Australia, 259.

Census of Red River settlement, in 1822,16 ; in $1849,27$.

Central Experimental Farm, Hard Red Calcutta wheat at, 204-205; organized by W. Saunders, 144; wheat crosses made at, 149.

Cereals, prototypes of, 285-286.

Ceres and the cerealia, 282-283.

Certificate of grade, 96.

Cherry, Dr., on value of Farrer's wheat-breeding work, 260.

Chess matches on farms, 140.
Chewing test, for gluten contents of wheat, 155, 201-203, 265266.

Chicago, and Velvet Chaff wheat, 149 ; highest price of wheat at, 124 ; prices posted at Winnipeg Grain Exchange, 105, 116.

Chinese, and origin of wheat, 280 ; wheat grown by, in early times, 279.

Chopping roots, engine for, 139.

Churches, number of, in Red River settlement in $1849,27$.

Churn, how driven, 138.

Cities and agriculture, 33-34; 278-279.

Clark, J. A., vide Ball and Clark.

Clearing House of the Winnipeg Grain Exchange, description of, 109-116; advantage to traders of, 113, 115.

Cleveland wheat, in Australia, 259.

Climate, and wheat quality, 199 ; claim respecting, for Quality wheat, .234, 236.

Clock, tell prices of wheat, 117118.

Club wheat, classification of, 292 ; replaced by Red Fife, 218, 227.

Cobourg, and Red Fife wheat, 214.

Colborne district of Ontario, 213.

Colorado, Marquis wheat in, 164.

Color, of flour, 199; of gluten of Marquis wheat, 155; of wheat grains, 221, 236, 260-262.

Colquhoun, M., on the origin of Red Fife wheat, 210.

Columella, mentions rust disease, 283.

Comeback wheat, in Australia, 259. 
Commission merchants, at Grain Exchange, 106; borrow for banks, 131.

Commission rule, value of, 107.

Consumers, represented on Board of Grain Commissioners, 128.

Contract grades, of wheat, 111112.

Cook, O. F., investigations on wild wheat, 290 ; illustrations by, $289,290,298$; on cross-fertilization of wild wheat, 300 ; on the origin of wheat, 298 299.

Corbett, J. C., on Burbank's new fruits, 232.

Corn, and wheat, battle with, 170 ; at Rosthern, 273 ; in 1822 , 16 ; northern advance of, 187190.

Council of Assiniboia, 28.

Country elevators, controlled by farmers, 142; cost of building, 131; definition of, 53 ; description of, 56-57; shipping grain from, 57-58; weighing wheat at, 98-100.

Country Gentleman and Cultivator, and Red Fife wheat, 206.

Cream-separator, how driven, 138.

Credit, importance of, 133; principle of velocity of, 132 ; use of, in crop movements, 130-131.

Crete, wheat of, 279.

Crookston Milling Company, and Marquis wheat, 160.

Crops, destruction of by hail, 48; financing movement of, 130-134; statistics of, $35-40$; values of, in Canada, 256 ; values of, for Marquis wheat, 243246.
Cross, products of, between Red Fife and Hard Red Calcutta wheats, 205.

Cross-bred kernels, how produced, 219-221.

Cross-bred wheats, a remarkable product of modern botany, 187.

Cross-breeding of wheats, results of, 226.

Cross-fertilization, in wild wheat and other grasses, 299-306.

Crossing of wheat, occurs naturally, observed by Rimpau, 303.

Crossing of wheat species, 296.

Crossing wheats, by W. Saunders and his assistants, 148-150; failure with einkorn, 293; genealogical trees of Marquis, Ruby, and Prelude, 185; Marquis results from, 152; Red Bobs the product of a natural cross, 264-268.

Cross-pollination, in cultivated wheat, $300-301$; in wild wheat, 300 ; natural, of wheats, $265-$ 267 ; of wild grasses, Kerner's observations on, 304-306.

Cultivation of plants and civilization, 278-279.

Currants, called Climax and Saunders, 145.

\section{D}

Daotylis, time of pollination of, 305.

Dakota Climax wheat, 149 .

Dakotas, and milling, 31 .

Damp wheat, milling value of, 104.

Danzig, and the origin of Red Fife wheat, 207-209, 214.

Dawson, Robert, and the origin 
of Dawson's Golden Chaff wheat, 224.

Dawson City, and Prelude wheat, 184.

Dawson's Golden Chaff wheat, a mutation, 226.

de Candolle, Alphonse, on the origin of wheat, 279.

de Cow and Company, and seed corn, 187.

Delphino, on pollination of wheat flowers, 301-302.

Demeter, and the origin of wheat, 280-282.

de Meuron soldiers, 19-20.

de Vries, and dwarf Evening Primrose, 226; and the mutation theory, 229; on Burbank's contribution to the California fruit-growing industry, 231; on Burbank's potato, 232 ; on selection of cereals, 224 .

Dirigibles, possible future use of, 140.

Disease, resistance to, of wheat, 226.

Dissemination, of wheat, 294295.

Dobbin, F. H., on the origin of Red Fife wheat, 211-215.

Dockage, setting of, 82,88 .

Downy Riga wheat, and parentage of Ruby, 186.

Drills, for sowing wheat, 45.

Drought, and wheat-growing, 48.

Duluth, and export of Red Fife in $1876,30,216$; and Winnipeg Grain Exchange, 105; cars inspected at, 91 ; grading system at, 69 ; inspection of grain at, 78.

Dunvegan, and Ladoga wheat, 181.

Durum wheat, and wild wheat, 289 ; classification of, 292 ; in tombs in Egypt, 298; in western Canada, 42 ; percentage in crop of, 167-169; yield of, in the United States, 193-196.

Dwarf Marquis wheat, origin of, 225 ; a mutation, 226.

Dysentery, in the Red River Settlement, 27.

E.

Earliness in wheat, and frost, $180-183$; and gain of workingtime, 175-176; and rust, 176180 ; and storms, 176 ; difficulty of combining high yield with, 185; of Marquis, 154-155; of Marquis and Red Fife, 175; of Marquis and Prelude, 184; of Red Bobs, Marquis, and Kitchener, 270.

Early Java wheat, and Preston, 149 ,

Early Red Fife wheat, a mutation, 226; and parentage of Red Bobs, 262, 263, 267-268; grown by Seager Wheeler, 262, 274.

Early Riga wheat at Fort Vermilion, 183.

Early-ripening corn varieties, 187-188.

Edgar, W. C., on a revolution in the milling industry, 31.

Edmonton, Dunvegan, and British Columbia Railway, 181, 183.

Edmonton, wheat shipped through, 183.

Education, cost of, and Marquis wheat, 256.

Eggs of wheat-plants, fertilization of, 219-220.

Egyptians, and the origin of wheat, 280. 
Egypt, ancient mills of, 294; durum wheat in tombs of, 294; wheat and civilization of, 279 .

Einkorn, and its prototype distinct from other wheats, 296297 ; classification of, 292 ; decrease of cultivation of, 295 ; not the progenitor of common wheats, 297.

Electric power, used to drive flour mills, 134 .

Electricity, in use on farms, 139. Elevator companies, borrow money from banks, 131; buy and sell wheat, 133 .

Elevators, and the Canada Grain Act, 68 ; choice of terminal, 102 ; compared with flat warehouses, 55; country, 56-57; country, cost of building, 131; hospital, 54; kinds of, 54-55; number of, 54; principle of, 53-54; terminal, 60-64.

Elliott, G. F. Scott, on the first harvest, 285.

Elymus, time of pollination of, 305.

Emmer, classification of, 292 ; decrease in cultivation of, 295 ; found in Egyptian tombs and in lake dwellings, 298; not grown in Syria and Palestine, 289 ; the only possible prototype of true wheat, 298-299; milled in ancient Egypt, 294; wild species of, 286.

England, and Yellow Stripe Rust disease, $178-179$.

Ensilage, corn used for, 189.

Epidemic and epiphytotic diseases, 177.

Essen, George, upon the origin of Red Fife wheat, 207-209, 210, $212,213$.

Europe, and grain exchanges,
118; receives Marquis wheat, 158.

Evans, Sandford, on east-bound movement of wheat, 50 .

Evolution, of man connected with wheat, 306; of wheat, 294-296. Exhibitions, agricultural, and Marquis wheat, 171, 173-174. Experimental farms, and W. Saunders, 144; three, in the Red River Settlement, 24-26; various wheats tested at, 146147 ; wheats crossed at, 148.

Experimental Farms Reports, $145,147,148,149,152,181$, $183,184,186,198,201,205$, 225,242 .

Exporters of wheat, deprived of business, 120, 126.

Export of wheat, financing of, 132; from Manitoba in 1876, 216; wheat sorts undesirable for, 149 .

F.

Fallow land, in western Canada and the United States, 252253 ; summer, principle of, 44 . Fanning mill, how driven, 139.

Fargo, Marquis wheat tested at, 159.

Farm, of Seager Wheeler, 272273.

Farmers, agrarian movement of, 141-153; and origin of Marquis wheat, 230 ; benefits to, from Marquis, 255-251; can supervise weighing, 99; complaints of, 68-69; need of money by, 130; own elevators, 142 ; private scales of, 99-100; receive grain prices from Winnipeg, 105; represented on Board of Grain Commission- 
ers, 127; terminal elevators of trading companies of, 102; tested Hard Red Calcutta wheat, 205.

Farming, implements of, improvements in, 138; mixed, introduction of, 43 ; use of straw in, 47.

Farm life, recent improvements in conditions of, 138-141.

Farms, and flying machines, 140141 ; area under cultivation in 1849,27 ; chess matches at, 140 ; first, in Red River Settlement, $9-10$; lighting plant for, 139 ; music on, 140; position of, in 1870,30 ; sanitation of, 139 ; telephones of, 140.

Farrer, William, wheat-breeding work of, in Australia, 259-260.

Federation wheat, in Australia, value of, 259 .

Fermenting cupboard, for breadmaking, 103, 203.

Fertilization of wheat eggs, 218220.

Fertilizers on farms, 43.

Festuca, time of pollination of, 305.

Fife, David, and Red Fife wheat, 206-207, 209, 210-212, 213, 214,215 .

Fife wheat, a name for Red Fife, 207; percentage of in crops, 167-169 ; replacement by Marquis in Minnesota, 246-248; yield of, in the United States, 193-196.

Financial business of forwarding erops divided, 132.

Financing grain sales, and grain exchanges, 119; by Wheat Export Company, 120-121.

Financing the crop movement, 130-134.
Finch, V. C., and O. E. Baker, on geography of wheat, 37, 39, 164.

Finlayson, Governor, 23.

Firbank wheat, in Australia, 259.

Fire, diminution in risk of, on farms, 139 .

Fisher's Landing, and Red Fife wheat, $30,216$.

Fishes, hunger prices for, in 1821, 14.

Fishing tackle, required in Red River Settlement, 28.

Flail, used in Red River Settlement, 16.

Flat warehouses, description of, 55.

Flax, erop in 1915, 36 ; questions respecting grading of, 104 .

Flood, in Red River Settlement, in $1825,18-19$; effect on crops, 20 ; refuge during, in 1852, 24.

Florence wheat, in Australia, 259.

Flour, amount of bran in, 23; Canadian, 200-201; export of, 135-136; fall in price of, 21; of Red Fife and Galician wheats, 209; price of, at Red River in 1814, 17; price of Vermilion, 181; purchased in the United States, 28-29; Red River, evil nature of, 21-24.

Flour mill, at Vermilion, 181; description of a modern, 137138.

Flour mills, of Minneapolis and Marquis wheat, 159 ; of western Canada, 134-138.

Flower of a wheat-plant, fertilization of the ovules, 219-220, 222 ; opening and pollination of, $300-304$.

Flying machines, and farms, 140. Food Control Bill, 126. 
Fort Abercrombie, and transport of flour, 29.

Fort Simpson, Ladoga wheat grown at, 181.

Fort Vermilion, amount of wheat grown at, 183; Ladoga wheat grown at, 181.

Fort William, and east-bound wheat traffic, 49-50; and futures in wheat, 133; and loading platforms, 54; arrival at, of wheat from Fort Vermilion, 183; clearance of wheat cargoes, 66-67; farmers' elevators at, 142; financing of crops to and from, 132; fixed prices of wheat at, 128-129; flour mills at, 134, 135; geographical position of, 108-109; grain doors removed at, 59; inspection of grain at, 78 ; official weighing at, 100 ; overfilled ears sent to, 87 ; price of wheat in store at, 93 ; sample room at, 69-70; terminal elevators at, description of, 6065 ; trains leaving Winnipeg for, 84; weighing and dockage, 82; wheat bought stored at, 112-113.

Fortyfold wheat, and Marquis, 165.

France, and Marquis wheat, 112113,228 ; purchase of wheat for, 124.

Fraser, J. D., inspector of wheat, 77.

Fraser wheat, and parentage of Prelude, 186.

Free Press corn, ripening of, 190.

Frost, and early-ripening wheats, $155,175-176$; and wheat-breeding in Canada, 146; danger of, in early fall to wheat, 43,48 ; dates of, in autumn, 180; frosted wheat kernels, 71 ; kills Turkey wheat, 166.

Fruits, improvement of, 145.

Fur trade, and the Selkirk Settlement, 5; through the Hudson Bay, 51.

Future, the, of Marquis wheat, 223-228.

Future trading, developed by grain exchanges, 118 ; benefits of, 133 .

Future trading in wheat, explanation of, 109-110; facilities for, taken away at Winnipeg, 122; prohibited in the United States, 126.

Futures, and the work of elevator companies, 133.

G.

Gage, J. C., on a crisis at the Winnipeg Grain Exchange, 122-125; on effect of war on the grain trade, 120.

Galicia, and origin of Red Fife wheat, 209.

Galician wheat, resembles Red Fife, 208-210.

Gallipoli Peninsula, dysentery at, 27.

Gambling on wheat, investigation of, 121, 125.

Garlach, Paul, wins a prize for wheat, 173 .

Gasolene engine, on the farm, 138-139.

Gehun wheat, and parentage of Ruby and Prelude, 186.

Genealogical trees of Marquis, Ruby, and Prelude wheats, 185. Genesee, Marquis wheat at, 165. Genoa wheat, in Australia, 259. Geographical position of the 
Winnipeg Grain Exchange, 108-109.

Geography of the World's Agriculture, 163-164.

Ghurka wheat, a parent of Little Joss, 179.

Glasgow wheat, 207, 215; and Red Fife, 207-211, 213.

Glumes, opening of, in flower of wheat, 301; vary in color in wild wheat, 289.

Gluten, elasticity of, from Marquis wheat, 155-156; in wheat flour, 199; quality of, 201-203.

Glyndon Fife wheat, compared with Marquis, 166, 170-171.

Goddess of agriculture, 280-283.

Godfrey, Mr., of the Andrews Grain Company, 160.

Godron, on time of opening of wheat flowers, 302.

Golden Drop wheat, replaced by Red Fife, 218, 227.

Gooseberries, improved by W. Sanders, 145.

Governing bodies and scientific research, 238-239.

Government of Canada, aid to farmers' elevator companies, 142 ; great success of its wheatbreeding experiments, 256 ; and the crop movement, 133; and the Winnipeg Grain Exchange, 125; appoints Board of Grain Commissioners, 127; commandeers wheat, 119 ; interior elevators of, 64 ; supervision by, at terminal elevators, 101102 ; takes control of grain business, 129; terminal elevators of, 102 .

Grade, certificate of, 90.

Graders, and their work, 82, 87, 89-90.

Grades of wheat, alteration in,
97-98; general description of, 70-75; line, and reinspection, $97-98$; mixing of, stopped in United States, 126; statistics of, for certain years, 92 ; stored separately at terminal elevators, 63 .

Grading of wheat, description of, 75-93; favorable for Marquis, 196-197; importance of, 9293 ; origin of, 69 ; out of terminal elevators, 95-96; regulations favor red wheats, 261 ; scientific investigations upon, 103 ; standard samples for, 87. Grain doors, 58-59.

Grain exchanges, development and advantages of, 118-119.

Grain Growers Export Company, business of, 143.

Grain Growers Grain Company, 142.

Grain Growers Guide, and Canadian wheat history, 208, 211; and Red Bobs wheat, 269 ; origin of, 142; yield of Marquis wheat, 191-192.

Grain Research Laboratory, the Dominion, description of, $102-$ 104 ; and Panama Canal, 52-53. Grain Standards Board, the western, and commercial wheat grades, 104.

Grain wagon, use of, 56.

Gramineæ, and eross-pollination, 300, 304-306.

Grand Forks, and Marquis wheat, $159,161$.

Grand Trunk Pacific Railway, and the wheat funnel, 49 ; terminal elevator of, 102.

Grangeville, Marquis wheat at, 165.

Grapes, selected by W. Saunders, 145. 
Grass family and cross-pollination, 300, 304-306.

Grasshoppers, and locusts, 11; plagues of, 10, 28.

Great Northern Railway, and J. J. Hill's wheat prize, 172 .

Greece, and Marquis wheat, 228; ancient, and wheat, 279.

Greeks, and the origin of wheat, 280.

Grinding grain, engine for, 139.

Grindstones, how driven, 139; teeth used as, 157.

Gunn, Donald, on rival fur companies, 5.

Gynerium argenteum, time of pollination of, 305 .

\section{H.}

Hackel, and wheat classification, 292-293; on lodicules of grass flowers, 304.

Haifa, experiment station at, 286.

Hail, danger of, $48,49,176$; destroys Seager Wheeler's crops, 268-269; insurance against, 48 ; resistance of wheats to, 276.

Hailstones, as large as hens' eggs, 48.

Half-breeds, in the Selkirk Settlement, 6, 7, 18.

Halifax, export of wheat from, $50-51$.

Halkett, and the Selkirk Settlement, 15 .

Hallet, and selections of wheat, 224 ; stimulates Haynes, 225.

Hanna, W. J., on consumption of wheat in Canada, 255.

Hanson and Barson, and Marquis wheat, 161 .
Hard and soft wheats, color of, 261-262; mixed by British millers, 200.

Hard Red Calcutta wheat, and parentage of Marquis, 151, 186, 218-223; origin of, 204-206.

Hargrave, J. J., on grasshopper plague, 28-29; on the Red River Settlement in 1870,29 30.

Harrison, T. J., grew wild wheat at Winnipeg, 291.

Harrowing of crops, 46.

Harrows, number of, in 1849, 27.

Hartney, James, his Red Fife wheat, 217.

Harvesters, visit western Canada annually, 47.

Harvesting wheat, and shelling, 197; with a brittle rachis, 294 ; description of, in western Canada,

Harvey, George, and White Bobs wheat, 270.

Harvey Milling Company, and Marquis wheat, 160.

Haussknecht, on wild einkorn, 296.

Hayes, H. K., and rust-resistance, 179; on natural crosses in wheat, 266-267; supplies information on Haynes' Bluestem wheat, 225.

Haynes, and his Bluestem wheat, 224.

Haynes' Bluestem wheat, compared with Marquis, 166, 170, 171.

Heating of wheat grains, 71 .

Hedged grain, not up to contract grades, 121.

Hedging of grain, explanation of, $110,133$.

Helm, H. S., on Marquis wheat, 159. 
Henderson, and Red Fife wheat, 214.

Hendrum, and Minnesota No. 23 corn, 188.

Hewitt, Gordon, on grasshoppers, 11.

Hill, James J., wheat prize offered by, 172 .

Himalaya Mountains, wheat brought from, 146.

Hoe, used for wheat culture, 2, $4,8,16$.

Holcus, time of pollination of, 305.

Holmes, wins a prize for wheat, 173.

Hoover, Herbert, appointed food controller, 126; regulates wheat export, 129.

Hordeum jubatum, its brittle rachis, 294.

Horses, death of, 18; improvement of breed of, 25 ; number in $1849,27$.

Hospital elevator, definition of, 54.

Hour-glass, the, in the Red River Settlement, 14-15.

Houses, number of, in Red River Settlement in $1849,27$.

Houston county, corn grown in, 189.

Howard, A., G. L. C. Howard and Rahman Abdur, on natural crossing of wheat in India, 301.

Hudson Bay, and elevators, 64; use of, 51 .

Hudson Bay railway, 51-52.

Hudson's Bay Company, at Fort Douglas, 8; change of route of, 29,51 ; gives a prize for wheat, 217; grant of, to Lord Selkirk, 1, 3; its roller mill at Vermilion, 181-182; market of, 30 ; purchase of flour, 21; rival of the North-West Company, 5; windmill of, 17.

Hulless barley, crossbred by C. E. Saunders, 240; evolution of, 295 .

Hulless oats, evolution of, 295. Huron wheat, origin of, 149 .

I.

Ice, and close of navigation, 63; thickness in Red River, 19.

Idaho, Marquis wheat in, 164, 165 .

Illinois, and the corn-belt, 187; Marquis wheat in, 164.

India, source of Hard Red Calcutta and Gehun wheats, 186; wheat exported in bags, 52; wheat in war-time of, 123; wheat varieties from, 146.

Indiana, and the corn-belt, 187; Marquis wheat in, 164.

Indian corn, in census of 1822, 16. Vide corn.

Indian Head, and Angus MacKay, 147; and the agrarian movement, 141; aboretum at, 140; Marquis wheat at, 157; Marquis procured from, 159; Ruby and Red Bobs wheat tested at, 185; tests for Bobs wheat at, 260,262 ; tests of Marquis at, 174-175; wheats crossed at, 148, 152; yield of Marquis at, 191, 196.

Indians, nickname colonists, 2; suffer from the Bloody Flux, 26.

Influenza, compared with the Bloody Flux, 26, 27.

Inland Empire, and Marquis wheat, 165 . 
Inland Revenue Department, and weighing grain, 99.

Inspection Divisions, for grain, 76.

Inspection of grain, by United States Government, 126; why concentrated at Winnipeg, 78.

Inspection of wheat, at terminal elevators, 93-96; charge for, 90 ; chief object of, 93 ; general description of, 75-93; space left above cars for, 58 .

Inspector, the Chief, 77, 78, 95, 96.

Inspectors, Deputy, 77; difficulties of, $75-76$; of scales, 99.

Interior terminal elevators, 64.

International Dry-Farming Congress, 173.

International Soils Produets Exposition, 173-174.

Iowa, and the corn-belt, 187; Marquis wheat in, 164; yield of Marquis in, 192.

Irvine, J. T., information on wheat supplied by, 231, 243.

Italy, and Marquis wheat, 228.

\section{J.}

Jack River, as a refuge for the Selkirk settlers, $5,7,8$.

James, C. C., on Canadian wheat history, 208, $211,216$.

Japan, wheat varieties from, 146.

Jennison Company, W. J., and Marquis wheat, 161.

Jewish Agricultural Experiment Station, 286.

Jonathan wheat, in Australia, 259.

Jones Winter Fife and Marquis wheats, 165.
K.

Kamloops district, Marquis wheat in, 157.

Kanred wheat, at Seager Wheeler's farm, 273.

Kansas City, and Marquis wheat, 174; and Winnipeg Grain Exchange, 105.

Kaufman, E. E., on California fruit, 231.

Keewatin, flour mills at, 134, 135, 136-138.

Kenora, Couch-grass and Slender Wheat-grass at, 290; flour mills at, 134-135.

Kerner von Marilaun, on pollination of grasses, 304-306.

Kerosene engine, use of, on farms, 138-139.

Kharkov wheat, grown in Alberta, 42 .

Kherson, and wheat-growing, 182.

Kincardine parish, home of David Fife, 207.

Kingston, and Red Fife wheat, 212.

Kirchner, on pollination of wheat flowers, 302 .

Kitchener wheat, a mutation, 226 ; and hail, 276 ; earliness of, 270 ; its origin, 226, 275277 ; prize won with, 173.

Kitto, F. H., on the Peace River district, 183.

Kittson county, corn grown in, 189.

Koeleria, time of pollination of, 305.

Körnike, on opening of wheat flowers, 301-302; on origin of wheat, 285-286; on wheat classification, 292-293.

Kotschy, and wild wheat, 286. 
Kowalewski, observations on wheat and oats by, 182.

L.

Labor organizations, represented on Board of Grain Commissioners, 127.

Ladd, E. F., milling and baking experiments of, 203.

Ladoga wheat, in the Peace River Valley, 181, 183; introduced and tested by W. Saunders, 146-147; parent of Preston, Stanley, Huron and Percy, 149; replaced by Red Fife, 227.

Laidlaw, managed an experimental farm, 25.

Lake dwellings, emmer found in, 298.

Lake of the Woods, and flour mills, 134; two wild grasses at, 290.

Lake of the Woods Milling Company, 135; its quern and roller mill described and contrasted, 136-138.

Lake Shippers' Clearance Association, work of, 66-68.

Lake steamers, description of, 65-66.

Lake Winnipeg, and the Selkirk settlers, 7 .

Lamont, Samuel, first millwright at Red River, 17.

Lamps and lanterns, falling into disuse of, 139.

Larcombe, Samuel, wins a prize for wheat, 174 .

Lawrence, Sheridan, and wheatgrowing in far north, 183.

Le Couteur, and selections of wheat, 224.
Leighty, C. E., on crosses between wheat and rye, 266.

Lewiston, Marquis wheat at, 165.

Liberty oat, C. E. Saunders selects, 240 .

Light, and wheat-growing, 182.

Lighting plants, on farms, 139. Little Club wheat, and Marquis, 165.

Little Joss wheat, and crossbreeding, 226 ; rust-resistant in England, 179.

Liverpool, and Winnipeg Grain Exchange, 105, 116.

Loading platform, and Canada Grain Act, 68; description of, 54-55.

Loading wheat, speed of, at the lake front, 64 .

Loaves of bread, and Canadian flour, 200 ; from rusted wheat, 103.

Lodicules, function of, 303-304.

Logan, his wind-mill, 24.

London, and Panama Canal, 53, 103 ; and Winnipeg Grain Exchange, 105.

Luther, Martin, phrase used by, 61.

M.

Machinery, supplied by farmers' trading companies, 141-143.

Macdonell, Alexander, on grasshoppers, 10.

Macoun, John, on Selkirk settlers, 7.

Macoun, J. M., report on wheat grown in far north, 181.

Macoun, W. T., and parentage of Ruby wheat, 186 ; on work of W. Saunders, 145; wheat crosses made by, 148; work on apples of, 145 . 
Macdonell, Miles, leads Selkirk settlers, 1; on harvest of 1813 , 2 ; surrenders himself, 5.

MacDougal, John, quern of, 16.

MacKay, Angus, and MacKay pea, 240-241; and Marquis wheat, 159; procures Ladoga wheat, 147.

Mackay pea, named by $W$. Saunders, 240-241.

Mackensie, Donald, describes Red River colony in 1820, 20-21.

Mackensie River, and wheat, 181. Magill, Robert, advocated establishment of Grain Research Laboratory, 102; on the grading and inspection of grain, $55,64,68,76,78,79-82,95-$ $96,102$.

Manchurian barley, originated by C. E. Saunders, 239.

Mandscheuri barley, importation of, 239.

Manitoba, and a prize for wheat, 174 ; and the agrarian movement, 141; and the Survey Board, 97; boundary of, 3; corn gxown in, 189-190; Hudson Bay railway in, 51-52; first export of wheat from, 216 ; flour mills of, 134 ; formation of the Province of, 32; Marquis wheat introduced into, 157; obtains Red Fife seedwheat from Minnesota, 217218; shelling of wheat in, 197; tests for Marquis wheat in, 175; wheats crossed in, 148; yield of Marquis in, 190 , 196.

Manitoba Daily Free Press, on Red Fife wheat, 210, 227; on spring wheat in Ontario, 215.

Manitoba Grain Growers Association, organization of, 141.
Mannichtousan, king of Sis, obelisk to, 279.

Manure, use of, 43, 44.

Maple Leaf Milling Company Limited, 135.

Maritime Provinces and Marquis wheat, 157.

Marketing grain, by sample, 69 70 .

Marquis wheat, and Bobs, 260; and Burbank's Quality wheat, 233-237; and frost, 180-181; and hail, 276; and Hard Red Calcutta, 204-206; and its parent Red Fife, 218; and rust, 176-180; and the northward advance of the wheatbelt, 188; and the War, 228; as the offspring of Red Fife and Hard Red Calcutta, 218223; beneficial influence of, 154; classification of, 292 ; comparative yields of, in Canada and the United States, 196 ; compared with Minnesota standard wheat varieties, (Figs. 29, 30, 31) , 166, 170, 171 ; compared with Ruby and Prelude, 183-184; crop values in Canada and the United States, 243-246; discovery and introduction of, 144-257; discovery of, not accidental, 238 ; does not shell readily, 197; earliness and storms, 176 ; earliness and yield of, 174175 ; economic value of, 230 233 ; extraordinary example of vegetable increase, 170 ; favorable grading of, 196-197; first distribution of, 157; first grinding of, 156; future of, 223-228; genealogical tree of, 185; general description of, $170-172$; history of, not well 
known, 144; improvement of, 224 ; increased wealth brought by, to Canada and United States, 246-252; in the United States, 158-170; introduction of into western Canada, 157; investigation of qualities of, 154-157; its blessings to the world, 158; Kitchener the product of, 275 ; milling and baking qualities of, 198-204; natural crossing with Bluestem, 266-267; origin of, little known to farmers, 230 ; origin of name of, 154; percentage of crop of, 167-169; possible origin from wild wheat of Palestine, 291; prizes awarded to, 172-174; provision for, in grades of wheat, 72 ; selection of by C. E. Saunders, 151-154; sown on $20,000,000$ acres, 170 ; summary concerning, 25i258; value to North America and the world of, 257-258; why sought in British markets, 200 ; yield of, in Canada, 190192; yield of, in United States, 192-196.

Martin, Chester, on the history of the Selkirk settlers, 1-2, 6, $7,9,13,21,29$.

May and Company, L. L., and Marquis wheat, 161.

May wheat, a deal in, 111-113; highest price of, 121.

McAlister, J. E., quern of, 16.

McDonell, Alexander, the "grasshopper governor," his revels, 15 .

MeGill and Company, and Marquis wheat, 161.

McLauchlin and Moore, test Ladoga flour, 147.

McLeod, John, defends Red River Settlement, 5-6.
McMurray, J. L., wheat crosses made by, 148.

Medicine Hat, ears inspected at, 91; flour mills and natural gas, 134, 135 .

Mediterranean, civilization of, and wheat, 306.

Melica, time of pollination of, 305.

Mendel, Gregor, and rust-resistance, 179 ; laws of inheritance of, 229 .

Mennonites, settle on open prairie, 30.

Mensury barley, C. E. Saunders' selection from, 239.

Mentor, and Minnesota No. 23 corn, 188.

Mice, in granaries, 23; plague of, in $1825,18$.

Michigan, and Northwestern Dent corn, 190.

Milking machines on farms, 138. Mill, experimental, of C. E. Saunders, 156, 203; of Hudson's Bay Company at Fort Vermilion, 181-182; of Sheridan Lawrence at Fort Vermilion, 183; one destroyed in 1815,5 .

Mill elevator, definition of, 54 .

Miller, foreign, 132; British, mixes flour, 200.

Millers, at Winnipeg Grain Exchange, 106 ; competitive buying of, during war, 124; deal in futures, 109-110.

Milling, and mixed wheat, 162 .

Milling and baking qualities, of Ladoga wheat, 147; of Marquis, 155-157, 198-204; of Preston, Stanley, Huron, and Percy, 149; of Quality, 234; of Red Fife, 218; made by C. E. 
Saunders, 156; supreme test of wheat, 147.

Milling industry, effect of revolution in, 30-31.

Milling operations, early history of, in Red River Settlement, 16-18.

Mills, and Board of Grain Supervisors, 129; and grain exchanges, 118; Egyptian, for emmer wheat, 294; experimental, 103; Midget, 135; Minneapolis, 159; querns, 16-17, 136-137.

Milner, W. E., on effect of war on grain trade, 119-120; on number of cars of wheat passing through Winnipeg, 49; on wheat crop of 1915, 35-36, 254; on Winnipeg Grain Exchange, 105.

Minneapolis, and introduction of Marquis wheat, 160 ; and Winnipeg Grain Exchange, 105, 116; and Velvet Chaff wheat, 149; flour mills at, and Marquis wheat, 159; grading system at, 69 ; highest price for wheat at, 125; seed Marquis made available at, 164-165.

Minnesota, and earliness of wheats, 176; and Minnesota No. 23 corn, 188; and St. Paul railway, 32 ; and yields of several wheat varieties, 193196; as source of Red Fife wheat for seed in Manitoba, 217-218; chief wheat varieties of, and total crop, 167; corn culture in, 187-190; crop value of Marquis wheat in, 244-245; financial benefit to, from Marquis, 247-249 ; introduction of Marquis into, 158-165; Marquis in, 157;
Preston wheat in, 149 ; purifier introduced into, 30-31.

Minnesota Agricultural Experiment Station, and Marquis wheat, 192, 203-204; and Bluestem, 225; and Preston, 149 .

Minnesota No. 13 corn and No. 23 corn, origin of, 187-188.

Minnesota No. 188 wheat, name for Preston, 149.

Minnesota River, and transport of seed wheat, 13.

Minnesota University, and earlyripening corn varieties, 187188,190 ; and rust-resistance, 179 ; and spring wheat, 162; Marquis wheat tested at, 165 ; natural crosses of wheat at, 266.

Mitchel, a millwright in the Selkirk Settlement, 24.

Moisture, conservation of, in soil, 43, 44, 45-46; in wheat grains, 71, 198; in wheat samples, how estimated, 89.

Moisture-testers, the BrownDuvel, 89 ; other, 103.

Molinia, time of pollination of, 305.

Money, amount received in Prairie Provinces for grain, 106; inflated currency, 124; provided by banks, 131-132; required by farmers, 130.

Montana, and Northwestern Dent corn, 190; and yield of several wheat varieties in, 193-196; chief wheat varieties of, and total erop, 167; erop value of Marquis wheat in, 244-245; increased wealth from growing Marquis in, 249-252; introduction of Marquis into, 160; Marquis in, $164,166$. 
Montreal, Ogilvie flour mill at, 135; wheat traffic through, $49-50$.

Moosejaw, cars inspected at, 91; elerator, 64,102 ; inspection of grain at, 78 .

Moseow, Marquis wheat at, 165.

Mount Hermon, and wild wheat. 140.

Mummy wheat, its vitality lost, 280.

Music, on farms, 140.

\section{N.}

Nardus, time of pollination of, 305.

Nebraska, and the corn-belt, 187; introduction of Marquis wheat into, 160; Mrarquis in, 164.

Neolithic Period, and wheat, 284-285, 298.

New York, and Hudson Bay route, 51-52; export of wheat from, 50-51; farmers' export business from, 143.

New York State, Marquis wheat in, 164.

Nilsson-Ehle, H., and wheat selections, 224; on natural crosses in wheat, 266.

Noble, C. S., and a great yield of Marquis wheat, 191.

Norman County, and Minnesota No. 23 corn, 188.

North, the, and belts of wheat and corn, 187-190; wheat in the far, 182, 184.

North Dakota, and Haynes Bluestem, 224; and shelling of wheat, 197; and yields of several wheat varieties, 193-196; chief wheat varieties and total crop, 167; corn culture in, 187-189; crop value of Marquis in, 244-245; increased wealth from growing Marquis in, 249-252; introduction of Marquis into, 158-165; Marquis wheat in, 157 .

North Dakota Agricultural College, and H. L. Bolley, 161.

North Dakota Agricultural Experiment Station, and E. F. Ladd, 203.

Northrup Grain Company, and Marquis wheat, 159, 160.

North-West Company, amalgamation with Hudson's Bay Company, 9; charges against Lord Selkirk, 9; Fort Douglas captured and lost by, $7-8$; ruin Red River Settlement in 1815,5 .

o.

Oatmeal, in reserve at Selkirk Settlement, 14.

Oats, a sale of, in the wheat-pit, 117 ; as an admixture of wheat, S8; evolution of, 294 295 ; new variety of, 240 ; origin of, 285; wild, in Manitoba, brittle rachis of, 294; wild, time of pollination of, 305.

Ogilvie Flour Mill Company Limited, 16, 135.

O'Donoghue, C. H., on locusts and grasshoppers, 11.

Ohio, and the corn-belt, 187; Marquis wheat in, 164.

Onega wheat, and parentage of Ruby, 186.

Ontario, and Golden Chaff wheat, 224; and origin of Red Fife wheat, 207, 212, 214, 215; 
cause of improved barley production in, 239; export of Red Fife to, in 1876, 30, 216; flour mill at Port Colborne, 135; Marquis wheat in, 157; western flour mills of, 134-135.

Ontario Agricultural College, improvement in barley at, and its economic importance, 239 ; tests for winter wheat at, 224225.

Oregon, and yield of Marquis wheat, 192.

Osiris, and mythical origin of wheat, 280.

Otonabee, and Red Fife wheat, $206,207,210,212$.

Ottawa, crossed wheats transferred to, 148; Marquis wheat selected at, 151-152; Monthly Bulletin published at, 104 .

Ovid, on the rust disease, 283.

\section{P.}

Pacific North-West, Marquis wheat in, 165-166.

Palæolithic Period, and agriculture, 284.

Palestine, and wild wheat, 286291.

Palouse district, and Marquis wheat, 165.

Panama Canal, and elevators, 64; shipment of bulk wheat through, 52-53, 64, 103.

Panicum milliaceum, time of pollination of, 305 .

Paris, and Winnipeg Grain Exchange, 105.

Passenger pigeons, in Manitoba, 4-5.

Peace River valley, and Ladoga wheat, 181; and Red Fife, 184.
Peas, in census of 1822,16 ; new sorts of, 240-241.

Pembina, settlers go to, 11 .

Percy wheat, origin of, 149.

Persia, and primitive wheats, 296.

Perrigault, inventor of the purifier, 31 .

Peterborough, and Red Fife wheat, 207, 212-213.

Philadelphia, export of wheat from, 50-51.

Phleum, time of pollination of, 305.

Phonograph, on farms, 140.

Pigeons, Passenger, C. N. Bell on, 4-5; injury of crops by, 4 .

Pigs, number of, in $1849,27$.

Piper, C. B., on financing the crop movement, 130; on geographical position of the Winnipeg Grain Exchange, 109; on lake steamers, $65-66$; on prices of contract grades, $111-$ 112 ; on relative transportation costs, 66 ; on velocity of credit, 132 .

Plant-breeders, and origin of new wheats, 223-226; triumphs of, 228 .

Plant-breeding, much still to be done in Canada, 241.

Pliny, and the rust disease, 283.

Plows, absence of in Selkirk Settlement, 2,8 ; improvement of, 138 ; number of, in 1849,27 ; yields after plowing in 1824, 16.

Plowing, in western Canada, 43; tractor for, 139.

Poa, time of pollination of, 305 .

Polish wheat, classification of, 292.

Pollination, and origin of Mar- 
quis wheat, 219-220; in wild wheat, 300 .

Pompeii, and Ceres, 282-283.

Population, Lord Selkirk's prophecy concerning, 9 ; of the Red River Settlement in 1822, 16 ; in 1849,27 ; in 1870 , 29-30; in village of Winnipeg, 33.

Port Arthur, and east-bound wheat traffic, 49-50; and futures, 133; clearance of wheat cargoes at, 66-67; farmers' elevators at, 142; financing of crops to and from, 132; fixed prices of wheat at, 128129 ; geographical position of, 109-109; government elevator at, 102; grain doors removed at, 59 ; inspection of grain at, 78 ; official weighing at, 100 ; overfilled cars sent to, 87; price of wheat in store at, 93 ; sample room at, $69-70$; terminal elevators at, 60,64 ; trains leaving Winnipeg for, 84; wheat bought stored at, 112-113.

Port Colborne, mill at, 135 .

Port Hope, and origin of Red Fife wheat, 213.

Portland, Maine, export of wheat from, 50-51.

Portland, Oregon, export of wheat from, 52.

Port Nelson, and export of wheat from western Canada, 51.

Post, failed to find wild wheat in Palestine, 287.

Potatoes, in census of 1822,16 ; late-sown in 1822, 20 ; yield of, in $1813,2-4$.

Poulard wheat, classification of, 292.

Prairie, breaking of, 42-44; free- dom from trees of, 48 ; harvesting scene upon, 48-49.

Prehistoric man, and agriculture, 278-279.

Prelude wheat, and cross-breeding, 226; and northward advance of the wheat-belt, 188; and Quality wheat, 236 ; genealogical tree of, 185 ; general description of, 183-187; replaced Marquis locally, 227.

Preston wheat, admixtures in, in North Dakota, 162; and Marquis in the United States, 164; and parentage of Red Bobs, 262, 263, 267-268; at Fort Vermilion, 183; compared with Marquis, 166, 170-171; grown at Rosthern, 274; in Minnesota, 163; in United States, 149 ; origin of, 149.

Price of wheat, and grading of Marquis, 197; cause of high prices of, 124; fixation of, in Canada, 128-129; fixation of, in United States, 128; from which came Red Fife, 213; highest, at Chicago, 124; highest, at Minneapolis, 125; highest, at Winnipeg Grain Exchange, 121 ; in wheat-pit at Winnipeg, 116; of Burbank's Quality seed, 234; of different grades, 93 ; of May wheat, 111; of Red Fife in 1876 at Winnipeg, 216 ; remarks on, 106107.

Primitive man, and domestication of wheat, 306 ; and wild wheat, 288, 294-295.

Prince Albert district, Ladoga wheat procured from, 147.

Pringle, C. G., and wheat hybrids, 226.

Prizes for wheat, awarded to 
Marquis, 172-174; awarded to White Bobs, 270; in 1882 at Winnipeg, 217; won by Seager Wheeler, 274-275, 276.

Probe, for sampling grain cars, construction and use of, 8485.

Prosperity, of Red River Settlement in 1822, 20-21.

Puccinia graminis, action of fungus on wheat, 176-180.

Pullman, Marquis wheat at, 165.

Pumping water, how accomplished on farms, 138.

Punjab, natural cross-pollination of wheat in, 301 .

Purifier for flour, and hard spring wheat in Manitoba, 217 ; introduction into Minneapolis of, $30-31$.

\section{Q.}

Quality, in wheat, 198-200.

Quality wheat, Burbank's, and Marquis, 233-237.

Quantity wheat, Burbank's, 234235.

Quebec, Province of, Marquis wheat in, 157.

Quebec No. 28 corn, ripening of, 190.

Quern, brought by Doukabors, description of, 136-137; in Red River Settlement, 16-17.

\section{R.}

Rabbits and mice, periodic increase of, 18.

Rachis of wheat heads, brittle in certain wheats, 293-295; rigid derived from brittle, 296.

Railways, all-rail route for wheat, 63 ; and the wheat funnel, 49 ; and transportation by water, 66; conductor's train list, 83 ; grain trains at Winnipeg, 78; long haul of wheat on, 183 ; procession of grain trains on, 59 ; sampling grain on, 79-81; sealing cars of, 58; seals of, $83-84$; size of boxcars, 58.

Rain, danger of, to standing crops, 176; low rain-fall and fallowing, 44 .

Rasheyya, and wild wheat, $286-$ 288.

Raymond, and Marquis wheat, 173.

Recorder of Winnipeg Grain Exchange, presides over wheatpit, 118.

Red Bobs wheat, and hail, 276; at University of Saskatchewan, 270-271; description of, 272 ; future of, 227 ; origin of, 259 275 ; selection, multiplication, and distribution of, 268-270; shown at a show, 174; tests of, incomplete, 272 ; the product of a natural cross, 264268.

Red Chaff wheat, replaced by Red Fife, 227.

Red Fife wheat, and a natural cross, 265-266; and Hard Red Calcutta, 205; and frost, 180; and Marquis, 257; and Marquis in the United States, 164 ; and parentage of Marquis, 218-223; and shelling, 197; and Rust disease, 178, 180,214 ; a parent of Marquis and Ruby, 186-187; at Fort Vermilion, 184; classification of, 292; compared with Marquis in plot tests, 174-175; 
exported from Manitoba to Ontario in 1876, 216; famous during last century, 145-146; for seed in Manitoba, brought from Minnesota, 217; grinding of, 196-197; improvement of, 224 ; in definition of grades, $72-73$; introduction into United States, 215; in western Canada, 42; milling and baking qualities of, 198; name wrongly applied to Preston wheat, 149 ; origin of, 206218 ; origin of name of, 206 ; outyielded by Marquis, 157; parent of Preston and Stanley, 149 ; possible origin from wild wheat of Palestine, 291; price of, in 1843, 214; replaced by Marquis, 227, 253-254; the male parent of Marquis, 151; used in crossing experiments, 148; yield and earliness of, compared with Marquis, 190, 174-175; why sought in British market, 200.

Red River, as a main highway, 10 ; ice of, in 1825-26, 19.

Red River carts, number and use of, 29.

Red River Settlement, history of, 1-33; and Hudson Bay, 51.

Red Russian wheat, and Marquis, 165.

Regina, Marquis seed-wheat for United States procured from, 159 ; and Saskatchewan Grain Growers Association, 142; publication on rust disease at, 178.

Registration records, for wheat, 101.

Reinspection of wheat, 96-98.

Re-selection of wheats, by C. E. Saunders, 153-154.
Resistance to disease, by wheat, 179-180, 226.

Reubens, Marquis wheat at, 165 . Richardson, A. E. V., on Farrer's wheat-breeding work, 259-260.

Riel, Louis, insurrection of, 32 . Riga wheat, at Fort Vermilion, 183.

Rimpau, and selections of wheat, 224 ; on elongation of staminal filaments of wheat, 304; on lodicules of grass flowers, 304 ; on opening of wheat flowers, 303.

Rio Grande wheat, and a natural cross, 265-266.

Ripening of wheat, and latitude, 182, 184; comparative, of Marquis and Red Fife, 175.

Robenhausen, emmer found in lake dwellings of, 298.

Robertson, Colin, and return of settlers to Red River, 6.

Robigus, the rust god, 283-284. Roblin, R. P., on corn grown in Manitoba, 189.

Rocky Mountains, the, and Marquis wheat, 166, 192; and Quality wheat, 236.

Rome, and Ceres, 282-283; wheat of, 279 .

Root-rot of wheat, and diseaseresistance, 226.

Roseher, W. H., on Ceres, 283.

Rosh Pinar, wild wheat found at, 287-288.

Ross, Alexander, on Bloody Flux, 26 ; on census of 1849,27 ; on grasshoppers, 10-12; on mice, 18; on Red River flour, 2124 ; on the hour-glass, 14-15; on yields of wheat, 20 ; possible error in chronology of, 4. Rosthern, and origin of Red 
Bobs, 259, 262; Preston wheat grown at, 274; seed fair at, 270 ; yield of Marquis wheat at, 191 .

Rowley, H. C., on value of Californian fruit-growing industry, 231.

Royal Flour Mills, test Ladoga wheat, 147.

Ruby wheat, genealogical tree of, 185 ; general account of, 183187 ; may replace Prelude, 227.

Russel, Miller Milling Company, and Marquis wheat, 159, 160.

Russia, and wheat-growing in far north, 182; einkorn and emmer in, 295; Mennonites came from, 30 ; source of Ladoga and Onega wheats, 186; wheat locked up in, 123 ; wheat sought from, for seed, 213; wheat varieties brought from, 146.

Rust disease, and disease-resistance, 226; and earliness in wheats, 155; and Red Fife wheat, 207, 211; and Siberian wheat, 213 ; and wheat grains, 71; Black Stem, great losses due to, 180; danger of, in western Canada, 48; description of, 176-180; in antiquity, 283-284; resistance to, 178 ; Yellow Stripe, in England, 179. Rusted wheat grain, in 1916, 103 ; special grade for, 74.

Rye, crossed with wheat, 266 ; in 1813,4 ; origin of, 285 ; time of pollination of, 305 .

\section{S.}

St. Boniface, and the St. Paul railway, 32 .
St. Cloud line, and corn culture, 189.

St. John, export of wheat from, 50-51.

St. Lawrence River, and export of wheat, 50-51.

St. Paul, and Red River carts, 29 ; building of railway from, 32 ; flour conveyed through, to succor Red River settlers, 28; corn obtained from, 187.

St. Paul railway, the, building of, 32 ; export of wheat by, 217.

Sample bags, weight of contents of, 86 .

Sample market, the, 69-70, 96.

Sampler or stabber, structure and use of, 84-86.

Samplers, a gang of, 80 .

Samples of wheat, how taken at a terminal elevator, 94; how taken on a steamer, 96; how stored at Winnipeg, 82, 90; sale of, by Inspection Department, 91 .

Sampling grain, account of, $79-$ 81.

Sanitation on farms, improvement of, 139-140.

Sarnia, and Red Fife wheat in $1876,216$.

Saskatchewar, acreage and yield of wheat in, 35,36 ; and Ladoga wheat, 147; and Marquis wheat prizes, 173; and Prelude wheat, 184; and tests for Marquis wheat, 174-175; and the agrarian movement, 141; and the Survey Board, 97; durum wheat in, 42 ; export of grain from, through Hudson Bay, 51; flour mills of, 134; Marquis wheat in, 144; Marquis wheat introduced into, 
157; shelling of wheat in, 197; traffic with Red River in 1870, 29; University of, and rust-resistance, 179 ; wheats crossed in, 148; yield of Marquis in, 190, 191, 196.

Saskatchewan Coöperative Elevator Company, 128, 141-142.

Saskatchewan Grain Growers Association, organization of, 141.

Saskatoon, and Dwarf Marquis wheat, 225; and wild wheat, 291 ; number of cars inspected at, 91 ; elevator at, 64, 102 ; inspection of grain at, 78 .

Saunders, A. P., and parentage of Marquis and Prelude wheats, 186; assisted IV. Saunders, 145; biographical note upon, 151; made cross from which sprang Marquis wheat, 151; wheat crosses made by, $148,149$.

Saunders, C. E., and Burbank, 228-233; and the chewing test for wheat, 155, 201-203; and the northward advance of the wheat-belt, 190; and the rust disease, 180 ; appointed Dominion cerealist, 150 ; assisted W. Saunders, 145 ; biographical sketch of, 237-238; extraordinary value of his work, 256-257; his Early Red Fife wheat, 225 ; his original estimate of Marquis wheat confirmed, 158; his regard for the British market, 200; investigates qualities of Marquis, 154-157; isolates Marquis, 144; list of publications by, 242; Marquis, Ruby, and Prelude wheats, 183-187; names Marquis, 154; obtains a wheat naturally crossed, 265-266; on Bobs wheat, 260; on quality in wheat, 198; on the cross resulting in Marquis, 152; on the geography of Marquis, 164; on the origin of Red Fife wheat, 208-209; selects Marquis, 151-154; the first miller and baker of Marquis, 20I; wheat crosses made by, 148; wide range of work as a cerealist, 200; work upon barley, oats, and peas, 239242.

Saunders, W., and crossing wheats, 226; and Ladoga wheat, 181, 186; and Marquis wheat, 151 ; and peas, 240 ; introduced Hard Red Calcutta, 204; on effect of sunlight on wheat, 182; summary of work of, 144-151.

Seales, in country elevators, 99. Sclerochloa, time of pollination of, 305 .

Schliemann, on a cereal found at Troy, 297.

Schools, and Marquis wheat, 256 ; number of, in $1849,27$.

Schweinfurth, and the wild wheat, 286, 289.

Science, besom of, sweeps away superstitions, 284; pure, helps applied, 179.

Scientific research, and governing bodies, 238-239; and solution of grain problems, 103; value of, illustrated by success of Marquis wheat, 256-258.

Scotch Danzig wheat, name for Red Fife, 206, 208, 211.

Scotch Fife wheat, replacement of, by Marquis, 227.

Scotch wheat, name for Red Fife, 207. 
Scotland, and Red Fife wheat, 207-208.

Screenings, at country elevators, 56.

Sealing railway cars, after inspection, 81,84 ; at country elevators, 58.

Seals of railway cars, breaking of, 83 ; construction of, 83 ; record of, 100.

Seattle, export of wheat from, 52.

Seed Fairs, Seager Wheeler at, 275.

Seed-testing laboratories, for wheat, 45.

Seed wheat, highest prices for, 234; of Marquis, first distribution in western Canada, 157; of Marquis, Kitchener, and Red Bobs, supplied by Seager Wheeler, 275; of Red Bobs, supplied by Grain Growers Guide, 269; of Red Fife, 217218; preparation and sowing of, 44-45.

Selection, of new wheat varieties, 224-227.

Self-fertilization, of wheat flowers, 222.

Self-pollination, of wheat flowers, 30I-303.

Selkirk, Lord, and the Kildonan farms, $9-10$; bears expense of seed wheat, 13; belief in experimental farms justified, 26 ; care of colonists by, 14 ; cost of experimental farm to, 25; death of, in France, 9 ; encouraged agriculture in 1815, 9; force sent by, 8; map showing his grant of land, 3 ; refers to a distillery, 18; remarkable prophecy of, 8-9; Semple's letter to, 7 ; sends a wind-mill to
Red River Settlement, 24; sends out a mill-wright in 1813, 17; sends settlers to Manitoba, 1; visits Red River Settlement in $1817,8-9$.

Selkirk Settlement, foundation of, 1 ; state of, in $1870,29-30$; value of, in $1822,16$.

Selkirk settlers, history of, 133 ; route of, in 1811-1815, 3.

Semple, Robert, calculation by, of wheat stored at Settlement in 1815,6 ; death of, in fight at Seven Oaks, 7 .

Serbes, cultivate einkorn and emmer, 296.

Serls, George, as Chief Inspector of grain, 77 ; on percentage of Marquis in western Canadian wheat crop, 243, 253.

Seven Oaks, fatal fight at, 7 .

Shaughnessy, Sir Thomas, wheat prize offered by, 172-173.

Sheep, number of, in $1849,27$.

Shelling, of Hard Red Calcutta, 205; resistance to, by Marquis, 197, 223.

Shipley, J. W., on extraordinary size of hailstones, 48 .

Shipping, facilities for, and position of flour mills, 134; of Marquis wheat across Atlantic, 158; of wheat, by lake shippers, 66-68; of wheat, oil Peace River, 183; shortage of, during war, 119.

Shirreff, and selections of wheat, 224.

Shutt, F. T., sections of papers on wheat written by, 242.

Siberian wheat, in Ontario, 213.

Sickle, used by Selkirk settlers, 16.

Sieving, of grain, 82.

Simpson, Governor, encourages 
agriculture, 21; his experimental farm, 25.

Smith, L. H., on natural hybrids of wheat, 266.

Smith's Creek, and Red Fife wheat, 213.

Smut disease, and disease-resistance, 226; bunt-resisting wheat, 259 ; in threshed wheat, 71 ; prevention of, 44-45; re'sistance to, 178.

Smut-mills, absence of in Selkirk Settlement, 22.

Social development, and agriculture, 278-279; the agrarian movement, 141-143.

Soil, fertility of, in 1813-1814, 2 ; preparation of, for crops, 42-44.

Solms-Laubach, the Count of, on the origin of wheat, 285 .

Sorghum, time of pollination of, 305.

South Dakota, and yields of several wheat varieties, 193-196; chief wheat varieties of, and total crop, 167; corn eulture in, 187; crop value of Marquis wheat in, 244-245; increase in wealth in, from growing Marquis, 249-252; introduction of Marquis into, 158-165; Marquis in, 157; Preston wheat in, 149.

Soy-beans, at Rosthern, 273.

Speculating in wheat, investigation of, 121.

Spelt, classification of, 292; decrease in cultivation of, 297 ; no very ancient remains of, 297.

Spread between wheat prices, nature of, 93 .

Spring wheat and winter wheat, in Minnesota, 162; in Selkirk
Settlement, I; in western Canada, 42.

Square Head's Master wheat, in England, 179.

Stabber, for sampling grain, structure and use of, 84-85.

Stakman, E. K., and rust-resistance, 179 ; on geography of Marquis wheat, 164.

Stamens of wheat flowers, rapid growth of filaments of, 304 .

Standard's Board for grain, 7475 .

Stanley wheat, origin of, 149.

Steele, R. C., takes wheat in 1876 from Manitoba to Ontario, 216.

Stink-weed, introduction of, into western Canada, 13.

Stocktaking of grain, at terminal elevators, 101-102.

Stone Age, and agriculture, 278.

Storage of wheat, in bulk, 9394.

Strabo, mentions rust disease, 283.

Straw, length of, for Marquis wheat, 223 ; of Kitchener wheat, 276 ; waste of, in western Canada, 46-47.

Strothers, and origin of Red Fife wheat, 206.

Stuart, William, on Burbank's potato, 232-233.

Stubble fields, wheat sown on, 43 .

Super wheat, Burbank's, 234235.

Supply and demand, law of, affects price of hard wheat, 200.

Swabians, grow einkorn and emmer, 295.

Swiss emigrants, at Red River Settlement, 14, 19-20.

Symes, inspector of wheat at lake front, 96. 
Syria, flora of, does not include wild wheat, 287; wild wheat found in, 290 .

\section{T.}

Telegrams, at Winnipeg Grain Exchange, 117; and geographical position of Winnipeg, 108.

Telegraphy, wireless, possible use of, 140.

Telephone, and geographical position of Winnipeg, 108; summoning of wheat traders to, 117; use of, on farms, 140.

Temperature, and opening of wheat flowers, 302-303, 306.

Terminal elevators, clearance of cargoes from, 67; some controlled by farmers, 142; definition of, 54 ; description of, 60 64 ; impression made on immigrant by, 60-61; inspection at, 93-96; weighing wheat at, 98100.

Test-plots, of C. E. Saunders at Ottawa (Figs. 23 and 24), 153, 157; of John Bracken, 270.

Theophrastus, mentions rust disease, 283.

The Pas, and the Hudson Bay Railway, 51.

Thew wheat, in Australia, 259.

Threshing machines, engines for, 139 ; improvement of, 138.

Threshing of wheat, and Marquis, 197; in western Canada, $46-47$; on ice-floes in Selkirk Settlement, 22.

Thompson, IV. P., and Dwarf Marquis wheat, 225; and rustresistance, 180 ; crossing experiments of, 267 ; his plot of wild wheat, 291.
Times, the, letters concerning Red River Settlement in, 28.

Toronto, and Red Fife wheat, 212,216 ; tests of Ladoga flour at, 147.

Tough wheat, milling value of, 104.

Trabut, on crossing varieties of Anagallis, 297.

Tractors, replacing horses on farms, 139.

Traill, Maulson, and Clark, import Red Fife, 218.

Trains, breaking up of, 94; procession of grain trains, 59; view of trains of Canadian Pacific Railway (Fig. 10), 57.

Transcona, elevator at, 64 .

Trees, planting of, on farms, 140 .

Trisetum, time of pollination of, 305.

Triticum, time of pollination of, 305 ; subdivisions of, 292 , 293.

Triticum dicoccum, and wild wheat, 290; not grown in Syria and Palestine, 289.

Triticum dicoccum dicoccoides, 289-291.

Triticum hermonis, conclusion concerning, 299; Cook's name for the wild wheat, 290-291.

Triticum monococcum, and wheat hybrids, 293; einkorn, 289.

'Triticum monoeoccum aegilipoide, found on Mount Hermon, 289.

Triticum polonicum, crossing of, 296.

Triticum vulgare dicoccoides, 286.

Troy, barley found in ruins of, 297.

Tryptolemus, and the origin of wheat, 280. 
Tullyallea, in Scotland, and David Fife, 207.

Turkey Red wheat, grown in Alberta, 42; in Inland Empire, 165; on Seager Wheeler's farm, 273 .

Turnips, in 1813 in Selkirk Settlement, 4.

\section{U.}

United Farmers of Alberta, the, organization of, 141.

United Grain Growers Limited, organization of, 141-142.

United Kingdom, purchase of wheat for, 124; rising wages in, 123.

United States, the, and blessings of Marquis wheat, 158; and cross-pollination in wheat, 301 ; and sample markets, 69 ; assists Red River Settlement, 28; crop value of Marquis in, 244-246; fixed prices of wheat in, 128; food controller of, 126 ; increased wealth in, due to introduction of Marquis, 246-252; introduction of Marquis into, 158-170; Marquis in, 153, 157; Marquis in 1914, 160 ; Preston wheat in, 149; reference map of States of, 163 ; revolution in milling industry in, 30-31; route to Red River Settlement through, 51; seed wheat obtained from, in $1820,12-13$; wheat export in 1913 , 39; wheat raised in, 40, 41 ; wheat varieties from, tested, 146; wild wheat brought to, 291.

United States Grain Corporation, action of, 126.
University of Minnesota, vide Minnesota University.

University of Saskatchewan, and Dwarf Marquis wheat, 225; and rust disease, 178, 179; crossing wheats at, 267; White Bobs grown at, 270-271; wild wheat grown at, 291.

University of Toronto, and Marquis wheat, 237, 238.

Universities and schools, eost of, and Marquis wheat, 256.

Unger, and wheat found in a pyramid, 279.

\section{V.}

Vancouver, and the Panama Canal, 103; government elevator at, 102; wheat exported from, 52.

Varro, mentioned rust disease, 283.

Velocity of credit, principle of, and crop movements, 132.

Velvet chaff wheat (Preston), and Marquis in the United States, 164; compared with Marquis (Figs. 29, 30, 31), $166,170,171$; percentage of crop of, 167-169; replacement by Marquis in Minnesota, 246248 ; various names for, and origin, 149; yield of, in United States, 193-196.

Vermilion, roller mill at, 181.

Vermont, home of C. G. Pringle, 226.

Vienna, discovery in a herbarium at, 286.

Vilmorin, on the crossing of wheats, 296.

von Marilaun, Kerner, on pollination of grasses, 304-306.

von Tschermak, wheat hybrids of, 296. 
W.

Wangen, emmer found in lake dwellings of, 298.

War, the Great, and part played by Marquis wheat, 255; and price of wheat, 255; and the Grain Growers' Export Company, 143; effect of peace on crop value of Marquis, 246; effect on grain trade of, 118129 ; efforts to increase crops during, 40 ; export of flour during, 136; increase of Marquis during, 164.

Warburg, and the wild wheat, 286.

Warehouse receipts, for grain, 100-101.

Warfare, delightful, with wheat and corn, 170.

Warren wheat, in Australia, 259.

Washing machine, how driven, 139.

Washington, Bureau of Crop Estimates at, quoted, 167; Monthly Crop Reports, 191, 244, 245, 247, 249, 251.

Washington States, and Marquis wheat, 160, 164, 165, 192.

Water-mills, number of, in 1849 .

Water power, and milling, 134.

Wealth increased by introduction of Marquis wheat, in Canada, 252-257; in North America, 257-258; in the United States, 246-252.

Weather, and yield of Marquis wheat, 196; during harvesting, 48; very cold, in, 1825-1826, 19.

Weeds, chief kinds of, 44 ; choke grain in 1813,5 ; harrowing to kill, 46 ; some introduced with seed wheat in 1820,13 ; on stubble fields, 43 .

Weed seeds in wheat, how estimated, 88 ; kinds of, $70-71$.

Weighing of wheat, at country elevators, 56; general account of, $98-100$; by graders at Winnipeg Grain Exchange, how accomplished, 82, 87-88.

Weighmaster, the Chief, 100.

Weight, of Ladoga wheat in far north, 181; of wheat in certain grades, $72-73$; of wheat per bushel, 175 .

Western Canada, crop statistics of, $35-40$; effect of revolution in the milling industry upon, 30-31; value of Marquis to, 256.

Western Canada Flour Mills Company Limited, 135.

Western Inspection Division, for cereals, 54, 59, 92.

Wheat, admixtures of, 70-71; and Hudson Bay railway, 5152 ; and farmers' trading companies, 141-142; and food, 227; and frost, 180-183; and rust disease, 175-180; and weather, 175-176; antiquity and origin of, 279-285, 298; as basis of Winnipeg's prosperity, 33 ; at terminal elevators, 6064; botanical classification of, 292-293; bought and sold at Winnipeg Grain Exchange, 111-118; bought and sold by elevator companies, 133 ; bushels raised in various countries, 40 ; cessation of future trading in, 122; cleaned for seed, 44; color of kernels of, 260-262; commandeered in 1915, 119; conclusion concerning, 306; contract grades of, 111-112; 
crop of, average in western Canada, 254; crop of, in 1821, 14; crosses of, with rye, 266; cutting of (Fig. 5), 45; destroyed by hail, 48 ; east-bound movement of, 50 ; effect of rising price of, 121-122; effect of war on, 118-129; estimating moisture in, 89; evolution of, from wild ancestors, 294-295; export of, in 1913, 39; export of, in 1915-1916, 40; famine price of, in 1826, 19; first export of, from Manitoba, 30 ; flowing property of, 53, 57; futures, $109-110$; future trading in, prevented, 126; general importance of improvement in, 230 ; gigantic monoply in, 126 ; grinding of, for Hudson's Bay Company, 23; harvesting of, in western Canada, 46, 47; heading out of, 46 ; heated, 71 ; highest prices at Chicago and Minneapolis, 124, 125; highest prices at the Winnipeg Grain Exchange, 121; high yield of and earliness of, antagonistic qualities, 185; hoeing of, 2 ; how shipped at lake front, 63 ; in box-cars, 57-59; in census of 1822,16 ; in country elevators, 56; in 1813, supposed high yield of, 4 ; in flat warehouses, 55; in lake steamers, 65-66; in sample markets, 6970; in western Canada, 35141 ; inspection of, $75-93$; latesown in 1822, 20; milling and baking properties of, 72 ; mixing of grades prevented, 126 ; moisture in, 71; natural crosses of, 265-267; new seed from the United States in 1820, 12-13; not descended from einkorn, 297; per capita production and use of, 39 ; population of, in a field, mixed, 224; price variations of, $106-$ 107 ; prices of, at grain exchanges, 116, 121, 124-125; prices fixed by Hudson's Bay Company, 22 ; prices of difierent grades, 93; quality of, 198-100; rapid loading of into steamers, 61 ; regulation of price of, 125-129; removal from farms of, $47-48$; research work on qualities of grain, 103; sampling of, 79-81, 8487 ; setting dockage of, 88 ; silver watch exchanged for, 14; smutted, 71; sown in 1812 and 1813 at Red River Settlement, 1; sown with drills, 45; standard samples of, 87 ; successful harvest of, in 1815, 6; the Great Funnel, 49-5̃ 1; the hour-glass, 14-15; the wheat clock, 117-118; time of pollination of, 305; tough and damp, 104 ; variations produced by crossing, 150; want of uniformity in, 162; winter, in western Canada, 41-42; yield per acre in various countries, 38.

Wheat-breeders, and the chewing test, 202.

Wheat-breeding, attitude of Seager Wheeler towards, 273; success of, in Canada, 256; work of W. Saunders upon, 144-15 I.

Wheat Export Company, activity of, in 1916-1917, 120-122; origin of the, 120 ; president of the, 128.

Wheat-growing, chief difficulties of, 48; in the far North, 18I- 
183; general account of, in western Canada, 41-49.

Wheat kernels, development of, from ovules, 218-221.

Wheat Pit, the, at Winnipeg Grain Exchange, description of, 116-118.

Wheat plants, development of, 221-222; spring from fertilized eggs, 218-221.

Wheat Scab, a disease of wheat, $71,178,226$.

Wheats, cultivated, with a brittle rachis, 295.

Wheeler, Seager, and a yield of Marquis wheat, 191 ; a visit to his farm, 269, 272-273; biographical note upon, 274; hail destroys crops of, 268,269 ; his Red Bobs at Indian Head, 185 ; origin of Kitchener and Red Bobs wheats, 226; origin of Red Bobs, 259, 262-268; selection of Kitchener by, 275-277; sold White Bobs, 270; various selection work of, 273 ; wins prizes for wheat, 173-174.

White Bobs wheat, at Rosthern, 263-264.

White Clawson wheat, and Dawson's Golden Chaff, 224.

White Fife wheat, a parent of Huron and Stanley wheats, 149; a parent of Prelude wheat, 186-187; used for crossing, 148.

White Horse Plains, death of Indians on, 26.

White Russian wheat, replaced by Red Fife, 218, 227.

Wild barley, evolution of, 294295 ; its brittle rachis, 294.

Wild oats, evolution of, 294.

Wild wheat of Palestine, a virile vegetable, 291; general ac- count of, 278-299; in United States and Canada, 291; not an escape from cultivation, 289 ; rediscovery of, by Aaronsohn, 286-291.

Winds, and the shelling of wheat, 197; drying, and wheat-raising, 48, 176; hot, effect on wheat kernels, 199.

Wind-mills, in Selkirk Settlement, 24, 27; metal-frame, 138.

Winnipeg, advantageous geographical position of, 108-109; and loading platforms, 54; as center of grain inspection, 91 ; as converging point of the wheat funnel, 49 ; census of the village of, in 1870,32 ; concentration of inspection at, 78 ; daily car inspection at, 91; flour mills at, 134, 135; Grain Growers' Guide published at, 142; grain prices at, 105 ; Grain Research Laboratory at, 102; grain trains passing through, 59; introduction of the grading system into, 69; Red Fife wheat secured at, in 1876,216 ; short delay of grain trains at, $78,84$.

Winnipeg Board of Trade, and the Survey Board, 97.

Winnipeg Grain Exchange, an account of, 105-118; and Board of Grain Supervisors, 128; and data upon damage from the rust disease, 180 ; Censoring Committee of, 121; Clearing House of, 109-116; closure of, 119; exhibition of loaves at, 103-104; geographical position of, 108-109; highest price of wheat at, 121 ; grain inspection at, 78; Re- 
ports of, $35-36,41,91,105$, 106, 118-129; site once haunt of Passenger pigeons, 5; stops future trading in wheat, 122; wheat pit of, 116-118.

Winnipeg Survey Board, and reinspection, 97.

Winnipeg wheat market, competition of war buyers in, 124 .

Winter-spring wheat, at Seager Wheeler's farm, 273.

Winter wheat, and Marquis, 247-248; in Minnesota, 162, 167 ; in western Canada, 4142; sown at Red River Settlement in 1812, 1; yield of, in the United States, 193-196.

Wisconsin, and Northwestern Dent corn, 190; and Red Fife wheat, 206; Marquis wheat in, 164; seed wheat from, conveyed to Red River Settlement, 13.

Wittmach, on barley found at Troy, 297.

Wood, cutting of, on farms, 139.

Wood-lots, planting of, 140.

Women, increase ranks of workers, 123; on farms, 140.
Wyoming, Marquis wheat in, 164.

Y.

Yellow Dent corn, origin of, 187188.

Lellow Stripe Rust disease, in England, 179.

Yield of wheat, high, and earliness, 185; high, of Marquis, 155, 173; of Kitchener, 276; of Marquis and Red Fife, 175; of Marquis, and shelling, 197; of Marquis in the United States, 192-196; of Marquis in western Canada, 190-192; of Red Bobs, 272; of Red Fife in Wisconsin, 206.

Yukon, and Prelude wheat, 184.

Z.

Zavitz, C. A., on economic importance of O. A. C. No. 21 barley, 239; on origin of Dawson's Golden Chaff wheat, 224. 




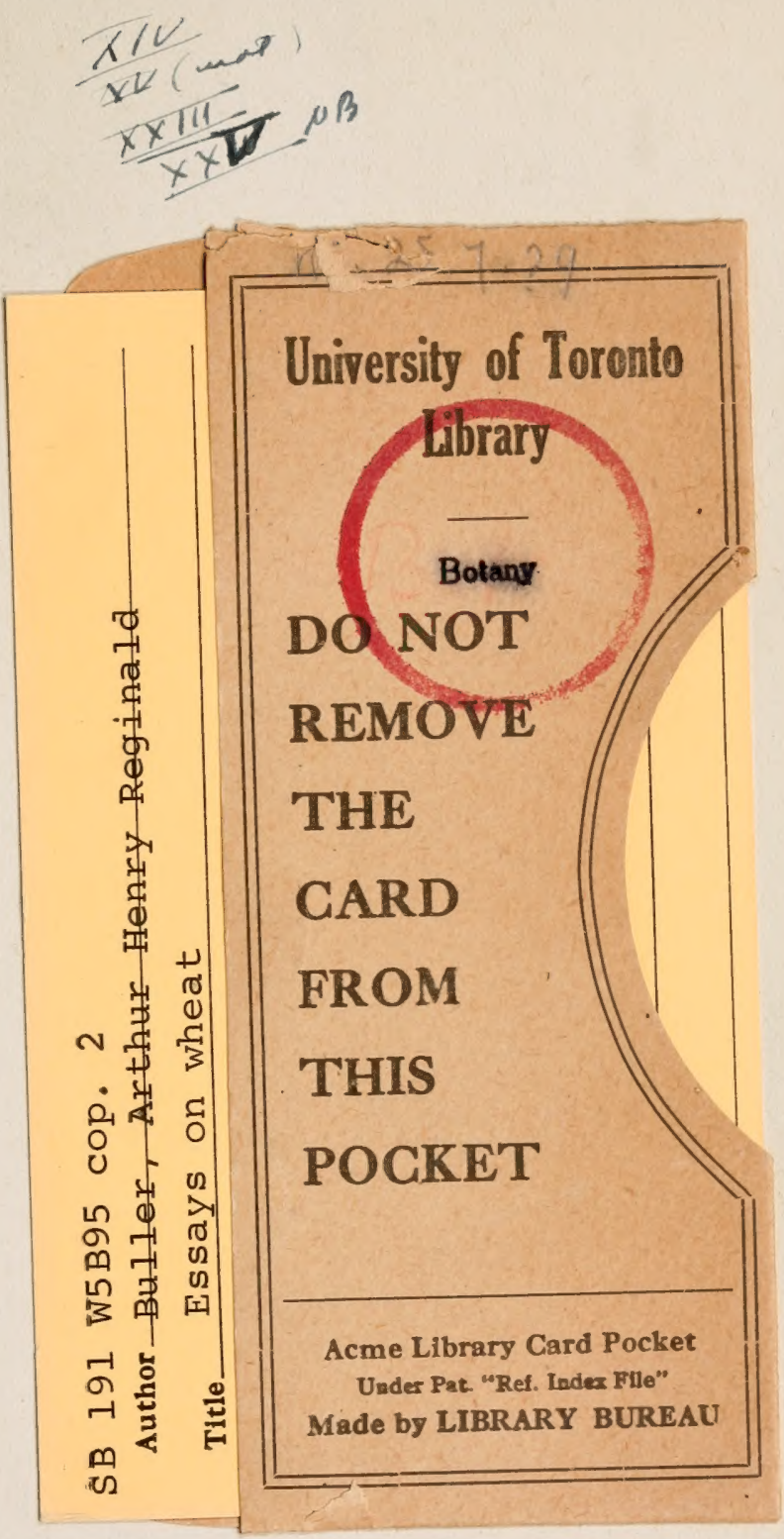
